\title{
Simulation of Canal and Control-Pond Operation at the Quivira National Wildlife Refuge, South-Central Kansas
}

By XIAODONG JIAN

\section{U.S. GEOLOGICAL SURVEY}

Water-Resources Investigations Report 97-4289

Prepared in cooperation with the KANSAS GEOLOGICAL SURVEY 


\section{U.S. DEPARTMENT OF THE INTERIOR \\ BRUCE BABBITT, Secretary}

U.S. GEOLOGICAL SURVEY

THOMAS J. CASADEVALL, Acting Director

The use of firm, trade, and brand names in this report is for identification purposes only and does not constitute endorsement by the U.S. Geological Survey.

For additional information write to:

District Chief

U.S. Geological Survey 4821 Quail Crest Place Lawrence, Kansas 66049-3839
Copies of this report can be purchased from:

U.S. Geological Survey Information Services

Box 25286

Federal Center

Denver, CO 80225-0826 


\section{CONTENTS}

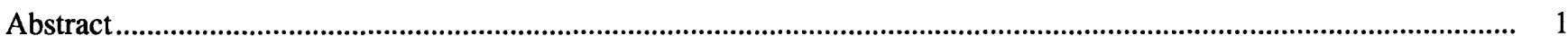

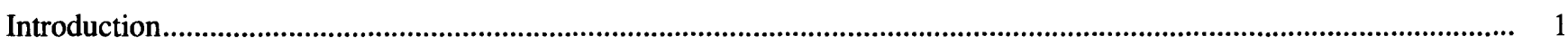

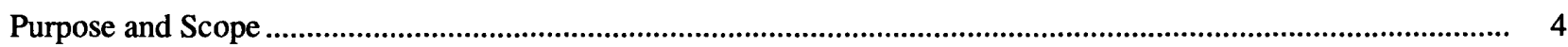

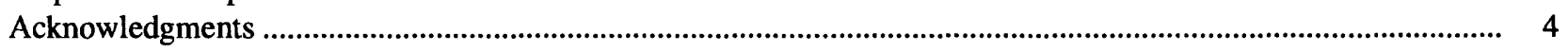

Physical and Hydrologic Features of Quivira National Wildlife Refuge ....................................................................... 4

Description of Refuge ................................................................................................................................................... 4

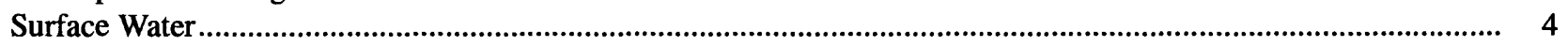

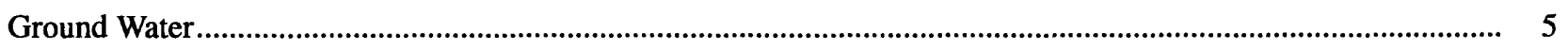

Physical Features of Control Ponds ................................................................................................................. 5

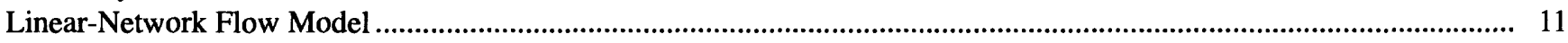

Network Representation of Flow Systems.....................................................................................................

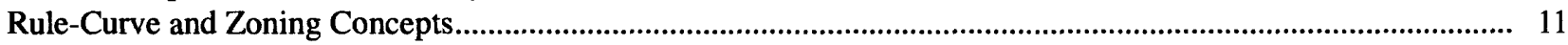

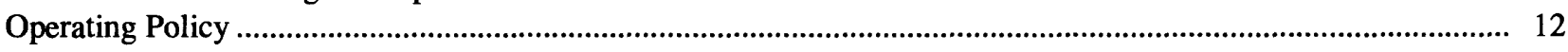

Mathematical Expression of Linear-Network Flow Model .............................................................................. 14

Canal Routing ................................................................................................................................................ 16

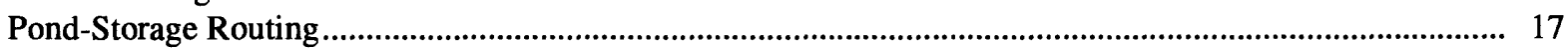

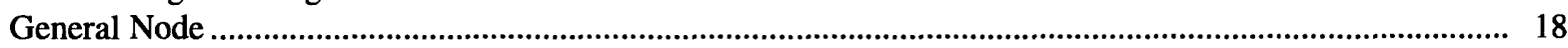

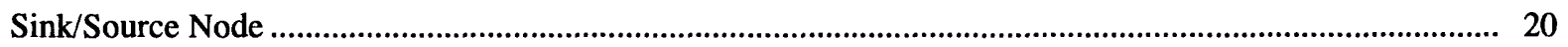

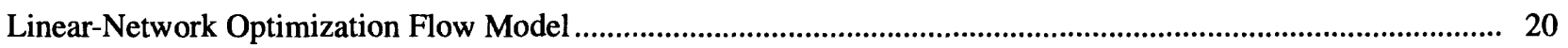

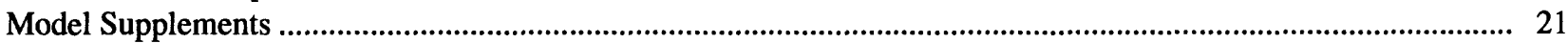

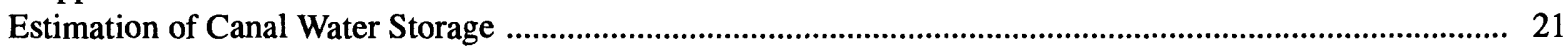

Estimation of Canal-Flow Transmission Losses.............................................................................. 21

Estimation of Direct Overland Surface Runoff ..................................................................................... 22

Flow Through Hydraulic Structures ................................................................................................... 23

Flow Over Sharp-Crested Weir................................................................................................................ 23

Flow Under Gate on Broad-Crested Weir............................................................................................ 23

Flow Under Gate on Spillway ......................................................................................................... 23

Pipe Outflow ........................................................................................................................................ 24

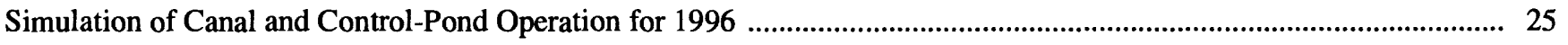

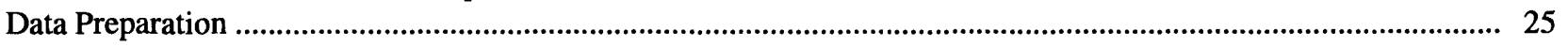

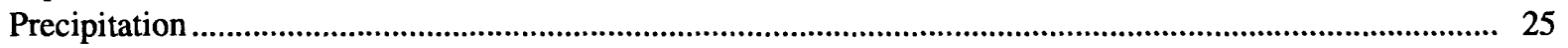

Water-Surface Evaporation .................................................................................................................... 25

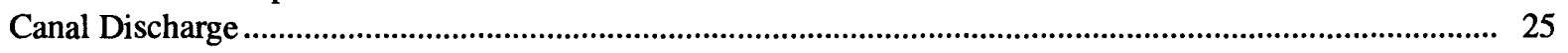

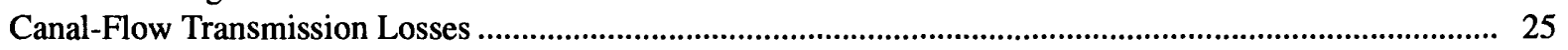

Ground-Water Discharge to Ponds ........................................................................................................ 25

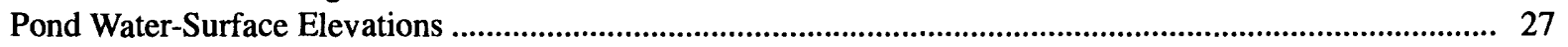

Pond Zoning and Operating Policy ................................................................................................................ 27

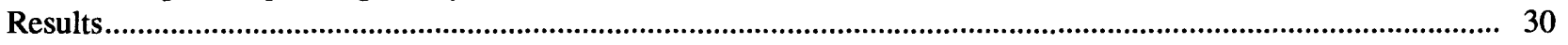

Simulation of Canal and Control-Pond Operation for 1991 Water Year ......................................................................... 33

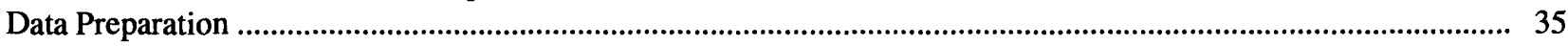

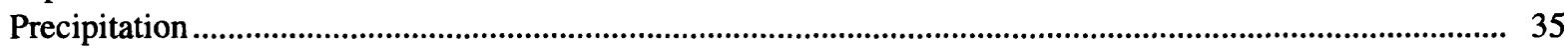

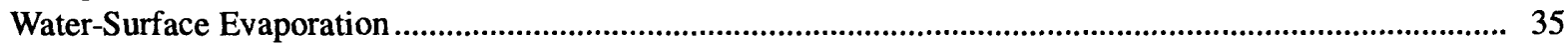

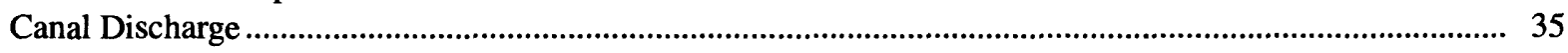

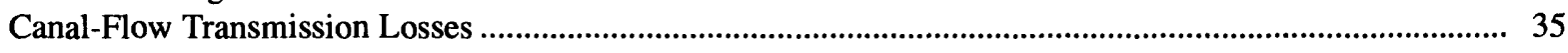

Ground-Water Discharge to Ponds ......................................................................................................... 35

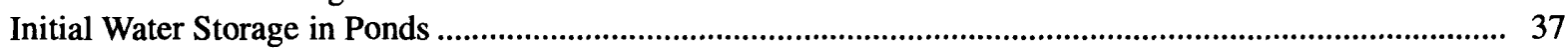

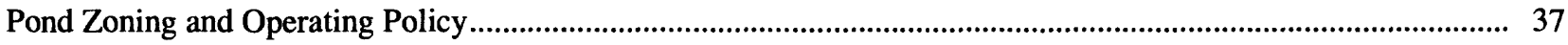

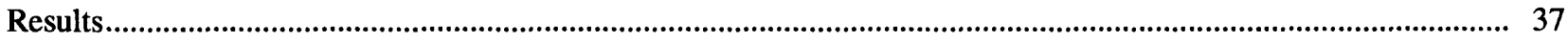


Summary...

References

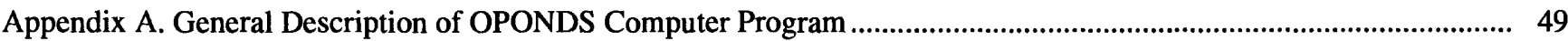

Appendix B. Input/Output Instructions for OPONDS Computer Program ............................................................... 51

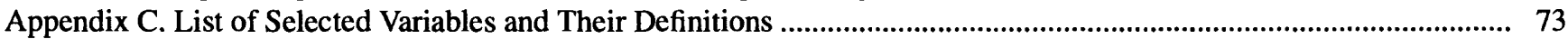

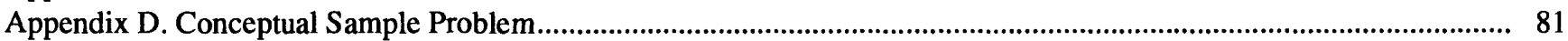

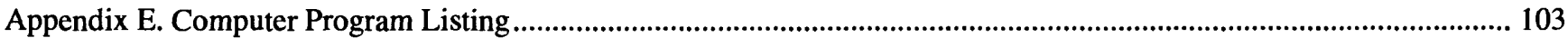

\section{FIGURES}

1. Maps showing location of Quivira National Wildlife Refuge, south-central Kansas ............................................. 2

2. Map showing ponds and canals at Quivira National Wildlife Refuge .................................................................. 3

3. Graph showing relations of water-surface elevation, water volume, and water-surface area for Little Salt Marsh... 12

4-10. Schematic diagram illustrating:

4. Network representation of flow systems at Quivira National Wildlife Refuge .......................................... 13

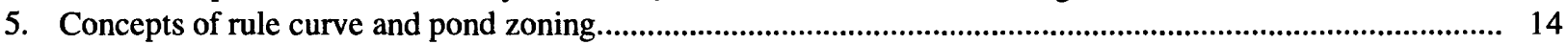

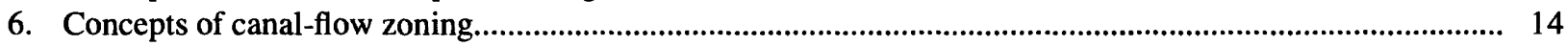

7. Water balance in a canal reach and arc-node representation of canal-flow routing........................................ 15

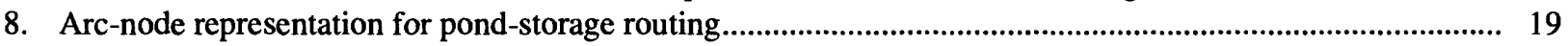

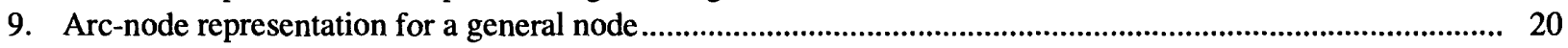

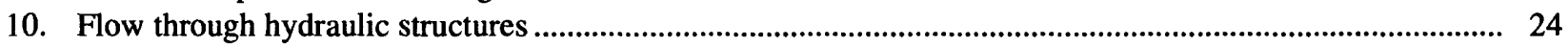

11-15. Graphs showing:

11. Daily precipitation, daily potential evapotranspiration, and daily mean discharge for Rattlesnake Creek,

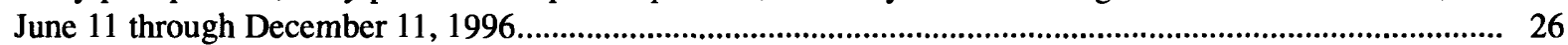

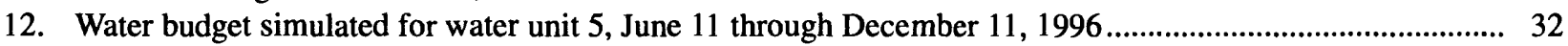

13. Daily precipitation, daily potential evapotranspiration, and daily mean discharge for Rattlesnake Creek,

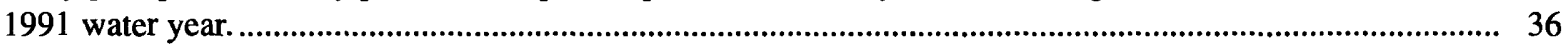

14. Water budget simulated for water unit 5,1991 water year ................................................................. 39

15. Simulated pond water storage with different rule curves for water unit 5 and water unit 78 , with initial storage at 80 percent of full-pond capacity, 1991 water year ................................................................... 42

16-17. Schematic diagram illustrating:

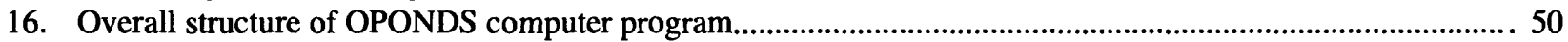

17. Network representation of flow system for sample problem .......................................................................... 82

\section{TABLES}

1. Drainage area and SCS curve number for control ponds at Quivira National Wildlife Refuge, south-central Kansas.....

2. Ground-water discharge to selected control ponds at Quivira National Wildlife Refuge for 1994

3. Full-pond elevations, water-surface areas, and capacities for selected control ponds at Quivira National Wildlife Refuge

4. Zonal elevation base and regression coefficients for elevation-volume-area relations of selected control ponds at Quivira National Wildlife Refuge.

5. Classification of antecedent soil-moistureconditions for SCS curve-number method of rainfall abstractions

6. Results of seepage tests along Rattlesnake Creek, 1996, at Quivira National Wildlife Refuge ............................. 27

7. Summary of water-surface elevations for selected ponds at Quivira National Wildlife Refuge, June 11 through December 11, 1996.

8. Initial storage, zoning, and penalty coefficients assigned to control ponds at Quivira National Wildlife Refuge, June 11 through December 11, 1996.

9. Penalty coefficients for canal flows at Quivira National Wildlife Refuge, June 11 through December 11, 1996.. 31

10. Water budgets simulated for selected control ponds at Quivira National Wildlife Refuge, June 11 through December 11, 1996

11. Water budget simulated for entire canal and control-pond system at Quivira National Wildlife Refuge, June 11 through December 11, 1996 


\section{TABLES-Continued}

12. Initial storage, rule curve, zoning, and penalty coefficients assigned to control ponds at Quivira National Wildlife Refuge, 1991 water year

13. Water budgets simulated for control ponds at Quivira National Wildlife Refuge with rule curve at 90 percent of full-pond capacity, 1991 water year.

Water budget simulated for entire canal and control-pond system at Quivira National Wildlife Refuge with rule curve at 90 percent of full-pond capacity, 1991 water year.

15. Water budgets simulated for entire canal and control-pond system at Quivira National Wildlife Refuge using different rule curves, 1991 water year.....

16. List of file codes and descriptions for OPONDS computer program.

17. File format for master file in OPONDS computer program.

18. File format for general network configuration and parameters

19. File format for initial pond condition and zoning

20. File format for network flow configuration.

21. File format for canal geometry and riverbed hydraulic parameters. 43

22. File format for outlet hydraulic-structure parameters

23. File format for surface-runoff parameters.

24. File format for relations among water-surface elevation, volume, and water-surface area of ponds

25. File format for regression relations of water-surface elevation, volume, and water-surface area of ponds

26. File format for seasonal target water demands.

27. File format for seasonal water-surface evaporation coefficients.

28. File format for seasonal flow boundaries

29. File format for seasonal pond rule curves

30. File format for local net incremental inflows

31. File format for precipitation data

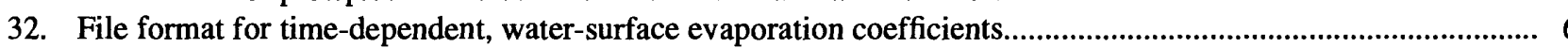

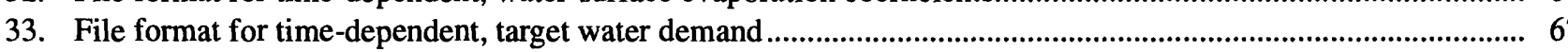

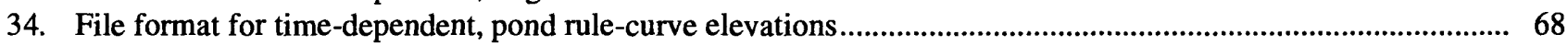

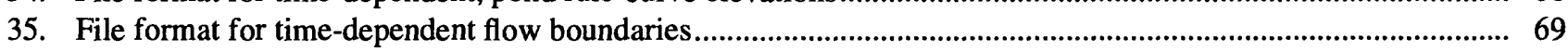

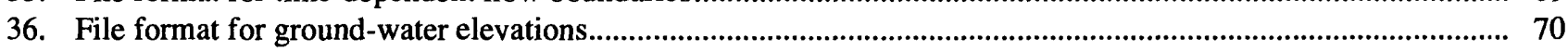

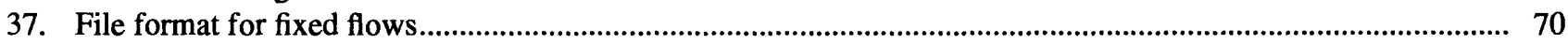




\section{CONVERSION FACTORS, ABBREVIATION, AND DEFINITIONS}

\begin{tabular}{rcl} 
Multiply & By & To obtain \\
\hline acre & 4,047 & square meter \\
acre-foot (acre-ft) & 1,233 & cubic meter \\
acre-foot per day (acre-ft/d) & 1,233 & cubic meter per day \\
cubic foot per day $\left(\mathrm{ft}^{3} / \mathrm{d}\right)$ & 0.02832 & cubic meter per day \\
cubic foot per second $\left(\mathrm{ft}^{3} / \mathrm{s}\right)$ & 0.02832 & cubic meter per second \\
foot $(\mathrm{ft})$ & 0.3048 & meter \\
foot per day $(\mathrm{ft} / \mathrm{d})$ & 0.3048 & meter per day \\
foot per second $(\mathrm{ft} / \mathrm{s})$ & 0.3048 & meter per second \\
& 0.3048 & meter per second \\
inch $(\mathrm{in})$. & 2.54 & squared \\
foot per second squared $\left(\mathrm{ft} / \mathrm{s}^{2}\right)$ & 25.4 & centimeter \\
inch per day (in/d) & 25.4 & millimeter per day \\
inch per year $(\mathrm{in} / \mathrm{yr})$ & 1.609 & millimeter per year \\
mile $(\mathrm{mi})$ & 1.609 & kilometer \\
mile per day $(\mathrm{mi} / \mathrm{d})$ & 0.03937 & kilometer per day \\
millimeter $(\mathrm{mm})$ & 0.03937 & inch \\
square foot $\left(\mathrm{ft}^{2}\right)$ & 0.09290 & square meter \\
square mile $\left(\mathrm{mi}{ }^{2}\right)$ & 2.590 & square kilometer \\
\hline
\end{tabular}

Temperature can be converted to degrees Celsius $\left({ }^{\circ} \mathrm{C}\right)$ or degrees Fahrenheit $\left({ }^{\circ} \mathrm{F}\right)$ by the equations:

$$
\begin{aligned}
& { }^{\circ} \mathrm{C}=5 / 9\left({ }^{\circ} \mathrm{F}-32\right), \\
& { }^{\circ} \mathrm{F}=9 / 5\left({ }^{\circ} \mathrm{C}\right)+32 .
\end{aligned}
$$

Sea level: In this report, "sea level" refers to the National Geodetic Vertical Datum of 1929-a geodetic datum derived from a general adjustment of the first-order level nets of the United States and Canada, formerly called Sea Level Datum of 1929.

Water year: Water year is the 12-month period October 1 through September 30. The water year is designated by the calender year in which it ends. Thus, the year ending September 30, 1991, is called the "1991 water year." 


\title{
Simulation of Canal and Control-Pond Operation at the Quivira National Wildlife Refuge, South-Central Kansas
}

\author{
By Xiaodong Jian
}

\begin{abstract}
Efficient water management of the Quivira National Wildlife Refuge, located in the Rattlesnake Creek Basin of south-central Kansas, is a complicated task. In a cooperative study with the
\end{abstract} Kansas Geological Survey, the U.S. Geological Survey developed a computer-based water-budget and flow-routing model to assist the U.S. Fish and Wildlife Service in determining the outcome of possible water-management options. The computer model uses network analysis to determine the optimal operation of canals and control ponds on the refuge. Applications of the model are presented that investigate the daily operation of canals and control ponds on the refuge using historical discharges and pond water levels.

Simulation of the daily operation of the canal and control-pond system at the refuge from June 11 through December 11, 1996, was conducted using the computer model. Simulated pond water levels matched well with measured ones. The root mean square error (RMSE) between the simulated and measured water levels in ponds was less than 0.13 foot except for two ponds. Water storage in ponds during the simulation period was substantially reduced due to water-surface evaporation and canal-flow transmission losses. Simulation of canal and control-pond operation was also conducted with different target pond water levels. This simulation used 1991 discharge, precipitation, and water-surface evaporation data to consider model results during drought conditions. Results indicated that lowering target pond water levels reduced water-surface evaporation, resulted in more water stored in ponds at the north end of the refuge, and caused a substantial decrease in the final volume of water stored in the main water-storage unit at the south end of the refuge (Little Salt Marsh).

\section{INTRODUCTION}

The Quivira National Wildlife Refuge is located in the Rattlesnake Creek Basin of south-central Kansas (fig. 1). The refuge was established in 1953 to provide food, water, and a resting place for waterfowl and certain endangered species during their annual migrations. To provide the proper type of feeding and resting areas for wildlife, water is diverted from Rattlesnake Creek into a system of canals and impoundments. There are more than 30 control marshes and ponds (collectively referred to hereinafter as ponds) (water units) ranging in size from 7 to 1,768 acres currently (1997) on the refuge, three main canals, and numerous smaller canals and waterways (fig. 2).

Water is managed to provide a mixture of marsh and wet-meadow habitat in and adjacent to the control ponds. Large ponds, such as Little Salt Marsh (water unit 5, fig. 2) at the south end of the refuge, provide habitat and serve as the main water-storage units on the refuge. It is difficult for the refuge manager to determine optimally how much water should be stored in the large ponds instead of being released to smaller ponds. Habitat losses occur when water is too deep in the larger ponds and also when there is insufficient water to supply the smaller ponds.

An additional complication in the surface-water management of the refuge results from ground-water inflows to the area. The north part of the refuge is within a ground-water discharge area, and some of the 


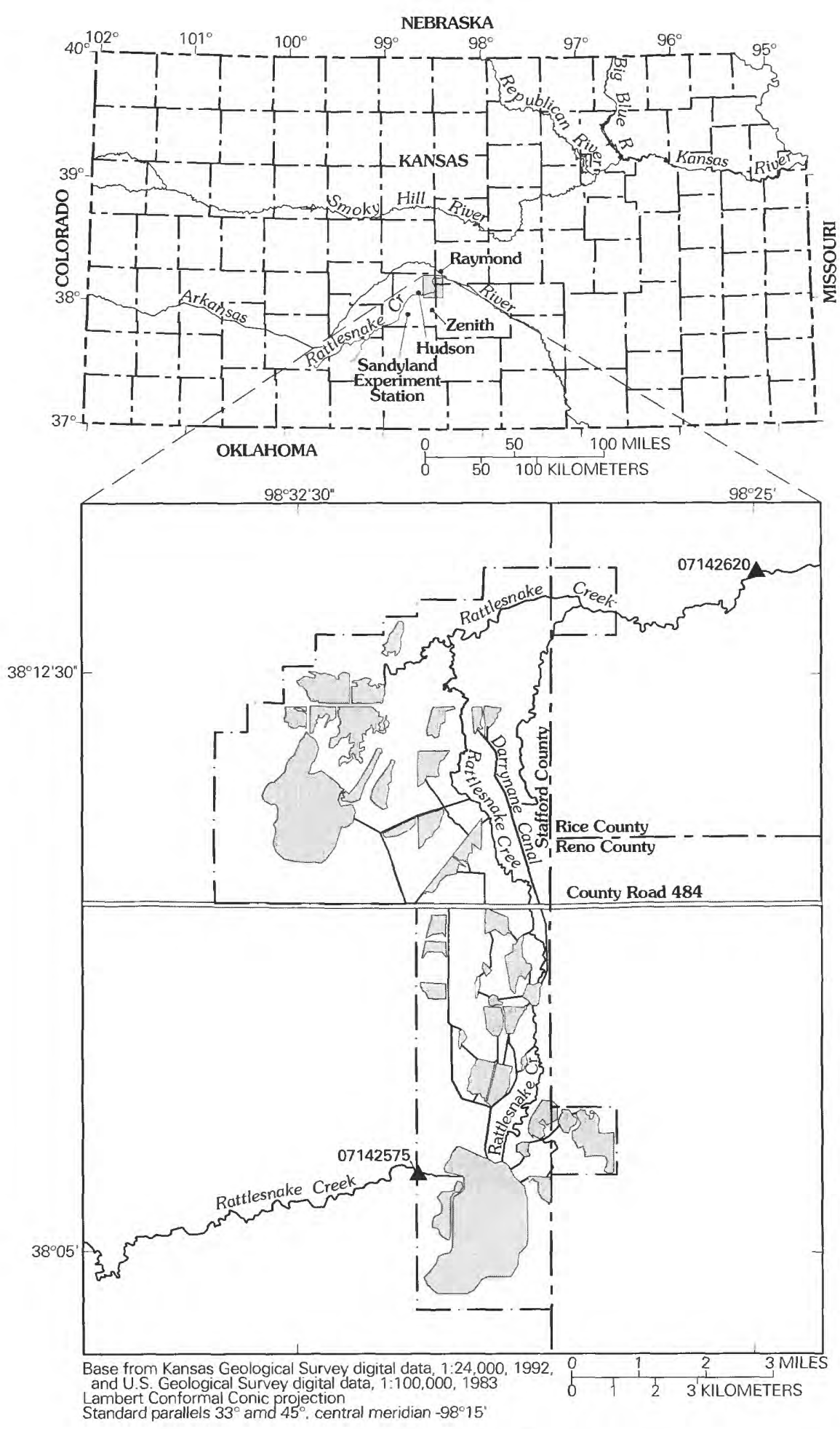

\section{EXPLANATION}

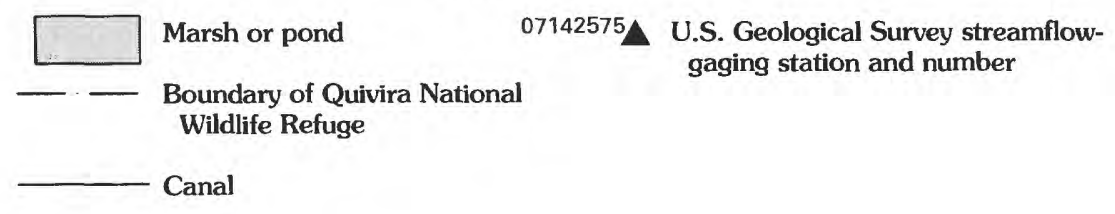

Figure 1. Location of Quivira National Wildlife Refuge, south-central Kansas. 


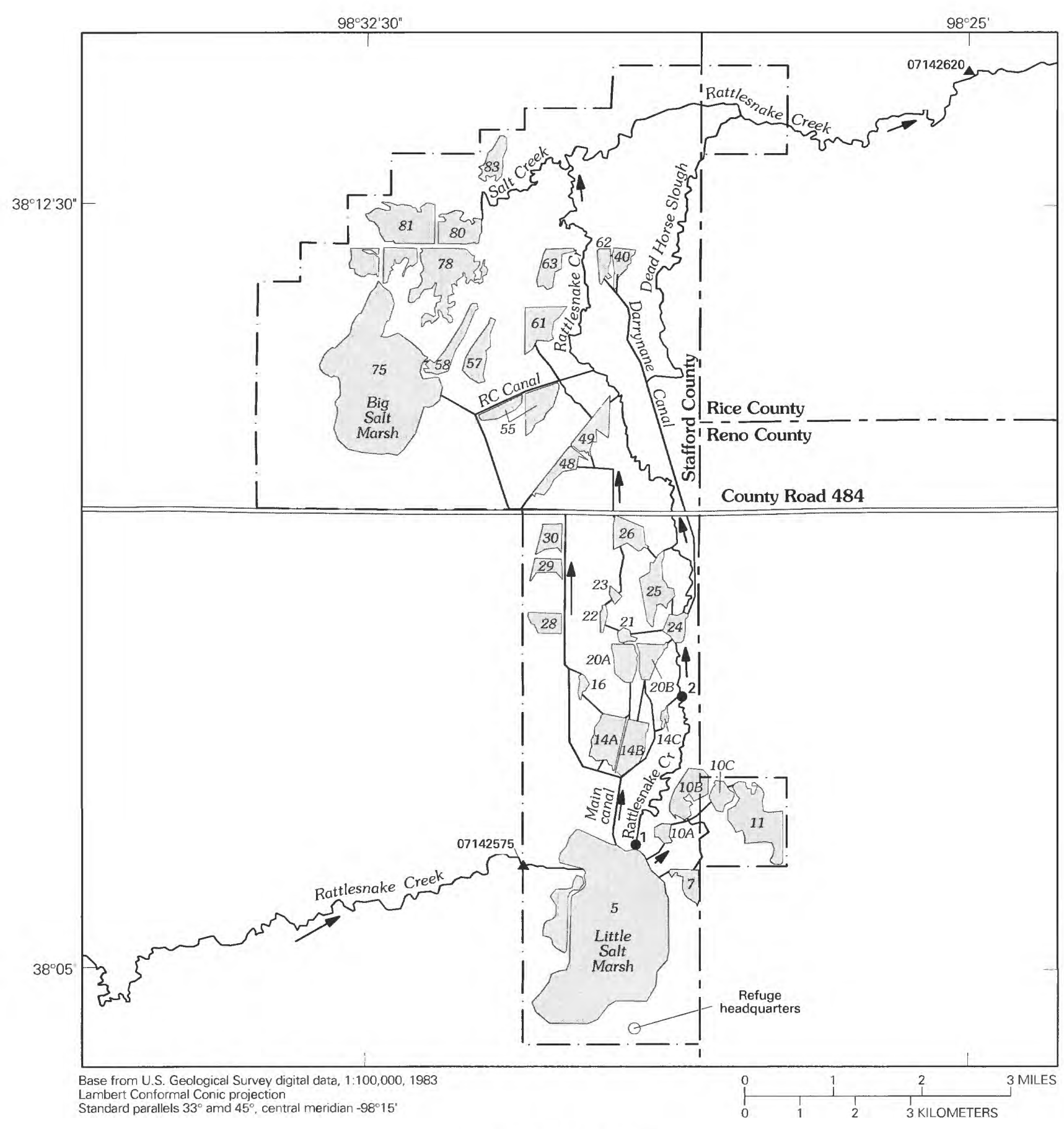

EXPLANATION

5 Marsh or pond-Number is water-unit number used for identification in tables

- - - Boundary of Quivira National Wildlife Refuge

Canal

$\longrightarrow \quad$ Direction of flow
07142575 A U.S. Geological Survey streamflowgaging station and number

-1 Seepage test site and number

Figure 2. Ponds and canals at Quivira National Wildlife Refuge. 
ponds receive a large part of their total water supply from ground-water sources (Megan Estep-Johnston, U.S. Fish and Wildlife Service, written commun., 1995). This is especially true of Big Salt Marsh (water unit 75 , fig. 2 ). It is very difficult to determine the volume of water that is contributed to the refuge water supply from ground-water sources without a comprehensive simulation study.

Beginning in 1995, a 3-year study to develop a water-budget and flow-routing model to assist the U.S. Fish and Wildlife Service (USFWS) in determining the outcome of possible water-management options was begun by the U.S. Geological Survey (USGS) in cooperation with the Kansas Geological Survey (KGS). The objectives of the study were:

1. To develop a network flow model that incorporates linear-programming techniques to determine efficient management strategies for water use.

2. To provide simulation results using historic streamflow and water-level data.

The network flow model developed for this study can be adapted to any configuration of canals and ponds for similar water-management problems.

\section{Purpose and Scope}

The purpose of this report is to describe the development of a computer model to simulate the water budget and surface-water flow routing for the Quivira National Wildlife Refuge to help determine the effects of possible water-management options on the distribution of available water within the refuge. The report includes a description of a network model to simulate the water budget of the refuge and the routing of water throughout the refuge. The network flow model consisted of nodes and arcs, where a node was any location in the refuge where the water budget was computed.

Nodes represented all ponds, joints of canals, and any other terrestrial areas of interest. Arcs connected the nodes and allowed simulation of water movement from one node to another. A linear-network flow technique was used to simulate flow through arcs.

This report also presents results of simulations of daily operation of canals and ponds based on 1996 and 1991 conditions. The simulation for 1996 was used to investigate pond operation with measured pond levels. The simulation for 1991 was used to investigate the operation of ponds under drought flow conditions with different simulated pond target levels.

\section{Acknowledgments}

The author thanks Marios Sophocleous and Greg Pouch of the Kansas Geological Survey for providing valuable data and suggestions. The author also thanks Megan Estep-Johnston of the U.S. Fish and Wildlife Service and Quivira National Wildlife Refuge personnel for providing crucial information and essential hydrologic data. Special thanks are given to David M. Wolock and Andrew C. Ziegler of the U.S. Geological Survey for their advice throughout the study.

\section{PHYSICAL AND HYDROLOGIC FEATURES OF QUIVIRA NATIONAL WILDLIFE REFUGE}

\section{Description of Refuge}

Quivira National Wildlife Refuge is located in south-central Kansas in northeast Stafford County (fig. 1). The refuge covers about $32 \mathrm{mi}^{2}$. It contains more than 30 control marshes and ponds ranging in size from 7 to 1,768 acres and about $21 \mathrm{mi}$ of canals ranging in length from 0.1 to $7 \mathrm{mi}$ (fig. 2).

The nearest climatic station to the refuge is at Hudson, 9 mi west of the refuge (fig. 1). The Hudson station records daily precipitation and temperature. The Sandyland Experiment Station (approximately $18 \mathrm{mi}$ southwest of the refuge, fig. 1) is operated by the Kansas State University Agricultural Extension Office in Manhattan, Kansas, and has been recording hourly precipitation and temperature data for the last several years. Precipitation data also have been collected at the refuge headquarters (fig. 2) since 1996 and at the USGS streamflow-gaging station near Zenith (station 07142575, fig. 1).

\section{Surface Water}

The major source of water to the refuge is Rattlesnake Creek. Hourly streamflow of Rattlesnake Creek is recorded at USGS streamflow-gaging stations near Zenith (station 07142575) and near Raymond (station 07142620). The long-term, lowest, and highest annual mean discharges for Rattlesnake Creek near Zenith for the 1973 through 1995 water years were 50.6, 6.59, and $186 \mathrm{ft}^{3} / \mathrm{s}$, respectively (Putnam and others, 1996). For Rattlesnake Creek near Raymond, the long-term, low- 
est, and highest annual mean discharges for the same period were $48.4,2.77$, and $190 \mathrm{ft}^{3} / \mathrm{s}$, respectively (Putnam and others, 1996).

In addition to the water supplied by Rattlesnake Creek, surface runoff to ponds generated by precipitation also plays an important role. The delineated drainage areas of the ponds are listed in table 1 (Marios Sophocleous, Kansas Geological Survey, written commun., 1997). These drainage areas were used for the calculation of overland surface runoff to the ponds. Surface runoff was estimated using the SCS curve-number method (Soil Conservation Service, 1985). SCS curve numbers for control ponds at Quivira National Wildlife Refuge also are listed in table 1. A description of the SCS curve-number method is found in the section "Estimation of Direct Overland Surface Runoff."

The refuge currently diverts water from the Little Salt Marsh (water unit 5), which is supplied by Rattlesnake Creek, into the main canal and into water units 7 , 10A, 10B, 10C, and 11 (fig. 2). Water also flows from the Little Salt Marsh back into Rattlesnake Creek.

Water in the creek flows north to water unit 24, where part of the water is diverted into the Darrynane Canal and into units 21 and 25. Some water flows into Rattlesnake Creek north of unit 24 and is transported to the west and north into the units north of County Road 484 .

\section{Ground Water}

The ponds in the north part of the refuge are within a ground-water discharge area. Table 2 shows the estimated monthly ground-water discharge from shallow aquifers to ponds for 1994 (Marios Sophocleous, Kansas Geological Survey, written commun., 1997). These values were estimated using a previous ground-water simulation done by Sophocleous and Perkins (1992) and the delineated drainage area of the ponds (table 1). The total ground-water discharge to ponds for 1994 was about 6,200 acre-ft.

\section{Physical Features of Control Ponds}

Bottom elevations and full-pond capacities of control ponds are listed in table 3 (Megan Estep-Johnston, U.S. Fish and Wildlife, written commun., 1995). To express mathematically the elevation-volume-area relation of a pond, the pond storage was first divided into several water-depth zones. The number of zones
Table 1. Drainage area and SCS curve number for control ponds at Quivira National Wildlife Refuge, south-central Kansas

[SCS, U.S. Soil Conservation Service. Drainage areas and SCS curve numbers are from the Kansas Geological Survey (Marios Sophocleous, written commun., 1997)]

\begin{tabular}{|c|c|c|}
\hline $\begin{array}{l}\text { Water-unit number } \\
\text { (fig. 2) }\end{array}$ & $\begin{array}{l}\text { Drainage area } \\
\text { (acres) }\end{array}$ & $\begin{array}{l}\text { SCS curve } \\
\text { number }\end{array}$ \\
\hline 5 & $1,890.7$ & 74.020 \\
\hline 7 & 140.8 & 42.680 \\
\hline $10 \mathrm{~A}$ & 84.9 & 48.397 \\
\hline $10 \mathrm{~B}$ & 201.4 & 47.575 \\
\hline $10 \mathrm{C}$ & 84.5 & 47.575 \\
\hline 11 & 341.4 & 47.575 \\
\hline $14 \mathrm{~A}$ & 149.9 & 71.217 \\
\hline $14 \mathrm{~B}$ & 124.9 & 71.693 \\
\hline $14 C$ & 59.5 & 33.552 \\
\hline 16 & 180.0 & 40.753 \\
\hline $20 \mathrm{~A}$ & 179.4 & 58.461 \\
\hline $20 \mathrm{~B}$ & 116.4 & 73.101 \\
\hline 21 & 60.0 & 76.469 \\
\hline 22 & 82.5 & 45.543 \\
\hline 23 & 43.8 & 46.615 \\
\hline 24 & 259.9 & 51.636 \\
\hline 25 & 226.7 & 55.711 \\
\hline 26 & 194.7 & 67.952 \\
\hline 28 & 228.4 & 38.659 \\
\hline 29 & 78.9 & 60.995 \\
\hline 30 & 69.0 & 61.968 \\
\hline 40 & 207.2 & 42.018 \\
\hline 48 & 305.6 & 73.499 \\
\hline 49 & 137.4 & 71.000 \\
\hline 55 & 582.8 & 72.250 \\
\hline 57 & 257.5 & 69.910 \\
\hline 58 & 186.7 & 62.831 \\
\hline 61 & 258.8 & 71.481 \\
\hline 62 & 90.4 & 52.546 \\
\hline 63 & 201.4 & 71.000 \\
\hline 75 & $5,621.7$ & 69.583 \\
\hline 78 & 635.9 & 70.544 \\
\hline 80 & 187.1 & 70.544 \\
\hline 81 & 620.9 & 70.544 \\
\hline 83 & 149.4 & 70.544 \\
\hline Total & $14,240.5$ & \\
\hline
\end{tabular}




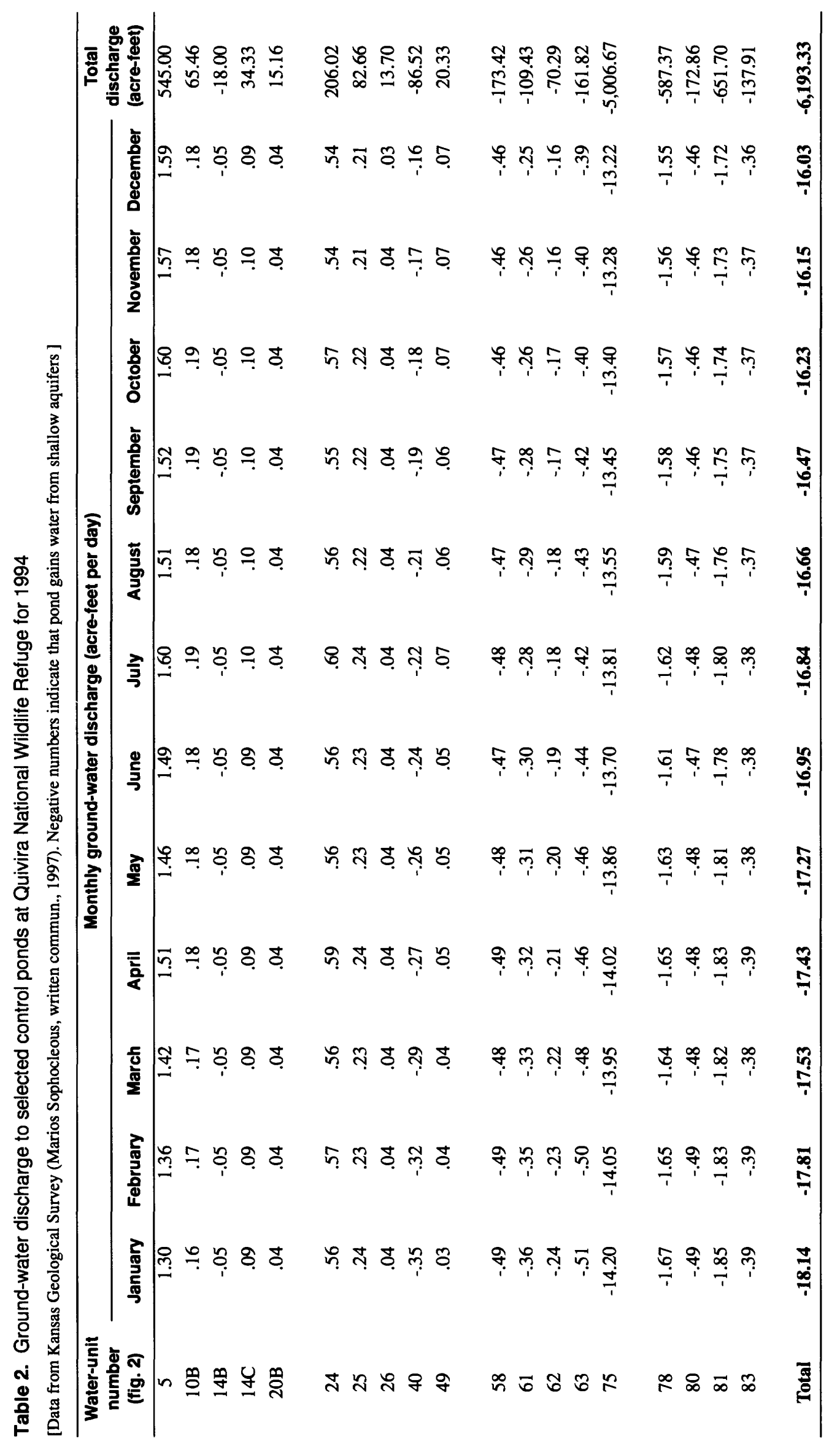


Table 3. Full-pond elevations, water-surface areas, and capacities for selected control ponds at Quivira National Wildlife Refuge

[Data from U.S. Fish and Wildlife Service (Megan Estep-Johnston, written commun., 1995). BM, bench mark; ft, feet]

\begin{tabular}{|c|c|c|c|c|c|}
\hline $\begin{array}{l}\text { Water-unit } \\
\text { number } \\
\text { (fig. 2) }\end{array}$ & $\begin{array}{c}\text { Bottom } \\
\text { elevation } \\
\text { (feet above sea } \\
\text { level) }\end{array}$ & Full-pono & $\begin{array}{l}\text { lelevation, in feet above sea level } \\
\text { (datum location) }\end{array}$ & $\begin{array}{l}\text { Full-pond } \\
\text { surface area } \\
\text { (acres) }\end{array}$ & $\begin{array}{c}\text { Full-pond } \\
\text { capacity } \\
\text { (acre-feet) }\end{array}$ \\
\hline 5 & 1,780 & 1,783 & (SPILLWAY) & 864 & 1,866 \\
\hline 7 & 1,774 & 1,778 & (TOP OF STOPLOG SLOT) & 26 & 40 \\
\hline $10 \mathrm{~A} \& 10 \mathrm{~B}$ & 1,774 & 1,779 & (TOP OF STOPLOG SLOT) & 64 & 145 \\
\hline $10 \mathrm{C}$ & 1,772 & $1,774.4$ & (TOP OF GAGE) & 11 & 13 \\
\hline 11 & 1,754 & $1,774.9$ & (SPILLWAY) & 90 & 338 \\
\hline $14 \mathrm{~A}$ & 1,772 & 1,778 & (SPILLWAY) & 87 & 196 \\
\hline 14B & 1,772 & $1,776.7$ & (SPILLWAY) & 65 & 96 \\
\hline $14 \mathrm{C}$ & 1,774 & 1,777 & $\left(14 C^{1} B M-0.67 f t\right)$ & 7 & 16 \\
\hline 16 & 1,768 & 1,775 & (TOP OF STOPLOG SLOT) & 31 & 80 \\
\hline $20 \mathrm{~A}$ & 1,767 & $1,770.7$ & (SPILLWAY) & 138 & 195 \\
\hline 20B & 1,767 & $1,770.7$ & (SPILLWAY) & 138 & 195 \\
\hline 21 & 1,764 & 1,770 & (TOP OF STOPLOG SLOT) & 30 & 81 \\
\hline 22 & 1,764 & 1,766 & $\left(22 \mathrm{~A}^{1} \mathrm{BM}-0.6 \mathrm{ft}\right)$ & 10 & 13 \\
\hline 23 & 1,762 & $1,764.3$ & (TOP OF GAGE) & 9 & 15 \\
\hline 24 & 1,765 & $1,769.4$ & (SPILLWAY) & 31 & 35 \\
\hline 25 & 1,762 & $1,768.4$ & (TOP OF GAGE) & 94 & 296 \\
\hline 26 & 1,758 & 1,762 & (SPILLWAY) & 59 & 111 \\
\hline 28 & 1,762 & 1,768 & $\left(28 \mathrm{~A}^{1} \mathrm{BM}-0.86 \mathrm{ft}\right)$ & 85 & 153 \\
\hline 29 & 1,757 & 1,762 & $\left(29 \mathrm{C}^{1} \mathrm{BM}-0.58 \mathrm{ft}\right)$ & 61 & 91 \\
\hline 30 & 1,756 & 1,759 & high water & 78 & 119 \\
\hline 40 & 1,736 & $1,742.5$ & $\left(40 \mathrm{~B}^{1} \mathrm{BM}-0.65 \mathrm{ft}\right)$ & 32 & 66 \\
\hline 48 & 1,750 & $1,754.4$ & (SPILLWAY) & 89 & 113 \\
\hline 49 & 1,750 & $1,754.2$ & (SPILLWAY) & 95 & 159 \\
\hline 57 & 1,740 & $1,743.5$ & $\left(57 \mathrm{~A}^{1} \mathrm{BM}-0.6 \mathrm{ft}\right)$ & 127 & 212 \\
\hline 58 & 1,736 & 1,742 & $\left(58 \mathrm{~B}^{1} \mathrm{BM}-0.5 \mathrm{ft}\right)$ & 99 & 251 \\
\hline 61 & 1,740 & $1,745.5$ & $\left(62 \mathrm{~B}^{1} \mathrm{BM}-0.58 \mathrm{ft}\right)$ & 218 & 498 \\
\hline 62 & 1,735 & 1,744 & (TOP OF STOPLOG SLOT) & 47 & 120 \\
\hline 63 & 1,736 & $1,741.2$ & (TOP OF GAGE) & 154 & 339 \\
\hline \multirow[t]{2}{*}{75} & 1,736 & $1,740.8$ & (SPILLWAY) & 1,768 & 2,446 \\
\hline & & & Total & 4,607 & 8,298 \\
\hline
\end{tabular}

${ }^{1}$ Letters indicate structure names where water levels are measured.

were different for different ponds. For example, the number of zones for water unit 5 and water unit 24 were two and five, respectively (table 4). The bottom elevation (above sea level) of each zone was called the zonal elevation base $\left(Z_{b}\right)$ for the corresponding zone. The elevation-volume-area relation of a pond was rep- 
Table 4. Zonal elevation base and regression coefficients for elevation-volume-area relations of selected control ponds at Quivira National Wildlife Refuge

[Data from U.S. Fish and Wildlife Service (Megan Estep-Johnston, written commun., 1995)]

\begin{tabular}{|c|c|c|c|c|c|}
\hline \multirow{2}{*}{$\begin{array}{l}\text { Water-unit } \\
\text { number } \\
\text { (fig. 2) }\end{array}$} & \multirow[b]{2}{*}{ Zone number } & \multirow{2}{*}{$\begin{array}{c}\text { Zonal elevation } \\
\text { base, } Z_{b} \\
\text { (feet above sea } \\
\text { level) }\end{array}$} & \multicolumn{3}{|c|}{ Regression coefficients } \\
\hline & & & A1 & A2 & A3 \\
\hline \multirow[t]{2}{*}{5} & 1 & 1,780 & 1.0000 & 308.1200 & 110.4650 \\
\hline & 2 & 1,782 & $1,059.0999$ & 749.9802 & 56.9399 \\
\hline \multirow[t]{3}{*}{7} & 1 & 1,774 & 0 & .1800 & 1.6575 \\
\hline & 2 & 1,776 & 6.9900 & 6.8100 & 4.7775 \\
\hline & 3 & 1,778 & 39.7200 & 25.9200 & 7.2600 \\
\hline \multirow[t]{3}{*}{$10 \mathrm{~A}$} & 1 & 1,774 & 0 & 6.2900 & 4.5450 \\
\hline & 2 & 1,776 & 30.7600 & 24.4700 & 3.6325 \\
\hline & 3 & 1,778 & 94.2300 & 39.0000 & 12.2525 \\
\hline \multirow[t]{3}{*}{ 10B } & 1 & 1,774 & 0 & 6.2900 & 4.5450 \\
\hline & 2 & 1,776 & 30.7600 & 24.4700 & 3.6325 \\
\hline & 3 & 1,778 & 94.2300 & 39.0000 & 12.2525 \\
\hline \multirow[t]{2}{*}{$10 \mathrm{C}$} & 1 & 1,772 & 0 & 3.6700 & .6825 \\
\hline & 2 & 1,774 & 10.0700 & 6.4000 & 5.3450 \\
\hline \multirow[t]{10}{*}{11} & 1 & 1,754 & 0 & .3000 & .5050 \\
\hline & 2 & 1,756 & 2.6200 & 2.3200 & .5700 \\
\hline & 3 & 1,758 & 9.5400 & 4.6000 & .5875 \\
\hline & 4 & 1,760 & 21.0900 & 6.9500 & .6975 \\
\hline & 5 & 1,762 & 37.7800 & 9.7400 & .7775 \\
\hline & 6 & 1,764 & 60.3700 & 12.8500 & .7150 \\
\hline & 7 & 1,766 & 88.9300 & 15.7100 & 1.5075 \\
\hline & 8 & 1,768 & 126.3800 & 21.7400 & 2.3025 \\
\hline & 9 & 1,770 & 179.0700 & 30.9500 & 3.0025 \\
\hline & 10 & 1,772 & 252.9800 & 42.9600 & 1.2850 \\
\hline \multirow[t]{3}{*}{$14 \mathrm{~A}$} & 1 & 1,772 & 0 & 3.6700 & 1.7150 \\
\hline & 2 & 1,774 & 14.2000 & 10.5300 & 7.9625 \\
\hline & 3 & 1,776 & 67.1100 & 42.3800 & 11.0625 \\
\hline \multirow[t]{3}{*}{ 14B } & 1 & 1,772 & 0 & .0800 & 2.5050 \\
\hline & 2 & 1,774 & 10.1800 & 10.1000 & 9.5525 \\
\hline & 3 & 1,776 & 68.5900 & 48.3100 & 12.1175 \\
\hline \multirow[t]{2}{*}{$14 \mathrm{C}$} & 1 & 1,774 & 0 & .3000 & 2.6500 \\
\hline & 2 & 1,775 & 2.9500 & 5.6000 & .3400 \\
\hline \multirow[t]{4}{*}{16} & 1 & 1,768 & 0 & .4700 & .9075 \\
\hline & 2 & 1,770 & 4.5700 & 4.1000 & .9850 \\
\hline & 3 & 1,772 & 16.7100 & 8.0400 & 4.5925 \\
\hline & 4 & 1,774 & 51.1600 & 26.4100 & 2.3550 \\
\hline
\end{tabular}


Table 4. Zonal elevation base and regression coefficients for elevation-volume-area relations of selected control ponds at Quivira National Wildlife Refuge-Continued

\begin{tabular}{|c|c|c|c|c|c|}
\hline \multirow{2}{*}{$\begin{array}{l}\text { Water-unit } \\
\text { number } \\
\text { (fig. 2) }\end{array}$} & \multirow[b]{2}{*}{ Zone number } & \multirow{2}{*}{$\begin{array}{c}\text { Zonal elevation } \\
\text { base, } Z_{b} \\
\text { (feet above sea } \\
\text { level) }\end{array}$} & \multicolumn{3}{|c|}{ Regression coefficients } \\
\hline & & & A1 & $\mathbf{A 2}$ & A3 \\
\hline \multirow[t]{4}{*}{$20 \mathrm{~A}$} & 1 & 1,767 & 0 & 0.8800 & 0.8400 \\
\hline & 2 & 1,768 & 1.7200 & 2.5600 & 20.9950 \\
\hline & 3 & 1,769 & 25.2750 & 44.5500 & 35.8750 \\
\hline & 4 & 1,770 & 105.7000 & 116.3000 & 15.8000 \\
\hline \multirow[t]{4}{*}{$20 \mathrm{~B}$} & 1 & 1,767 & 0 & .8800 & .8400 \\
\hline & 2 & 1,768 & 1.7200 & 2.5600 & 20.9950 \\
\hline & 3 & 1,769 & 25.2750 & 44.5500 & 35.8750 \\
\hline & 4 & 1,770 & 105.7000 & 116.3000 & 15.8000 \\
\hline \multirow[t]{2}{*}{21} & 1 & 1,764 & 0 & 1.4200 & 1.3675 \\
\hline & 2 & 1,766 & 8.3100 & 6.8900 & 2.8300 \\
\hline \multirow[t]{2}{*}{22} & 1 & 1,764 & 0 & 3.4700 & 1.6350 \\
\hline & 2 & 1,766 & 13.4800 & 10.0100 & 1.2825 \\
\hline \multirow[t]{2}{*}{23} & 1 & 1,762 & 0 & 3.7900 & 1.1625 \\
\hline & 2 & 1,764 & 12.2300 & 8.4400 & 1.0625 \\
\hline \multirow[t]{5}{*}{24} & 1 & 1,765 & 0 & .1600 & .3700 \\
\hline & 2 & 1,766 & .5300 & .9000 & .6200 \\
\hline & 3 & 1,767 & 2.0500 & 2.1400 & 3.5750 \\
\hline & 4 & 1,768 & 7.7650 & 9.2900 & 6.8600 \\
\hline & 5 & 1,769 & 23.9150 & 23.0100 & 10.3950 \\
\hline \multirow[t]{3}{*}{25} & 1 & 1,762 & 0 & .4600 & 2.3875 \\
\hline & 2 & 1,764 & 10.4700 & 10.0100 & 15.9925 \\
\hline & 3 & 1,766 & 94.4600 & 73.9800 & 4.1675 \\
\hline \multirow[t]{2}{*}{26} & 1 & 1,758 & 0 & 2.4800 & 5.4875 \\
\hline & 2 & 1,760 & 26.9100 & 24.4300 & 8.7050 \\
\hline \multirow[t]{3}{*}{28} & 1 & 1,762 & 0 & .0400 & .8125 \\
\hline & 2 & 1,764 & 3.3300 & 3.2900 & 6.7775 \\
\hline & 3 & 1,766 & 37.0200 & 30.4000 & 13.7275 \\
\hline \multirow[t]{6}{*}{29} & 1 & 1,757 & 0 & .0600 & .2650 \\
\hline & 2 & 1,758 & .3250 & .5900 & 1.6500 \\
\hline & 3 & 1,759 & 2.5650 & 3.8900 & 5.2800 \\
\hline & 4 & 1,760 & 11.7350 & 14.4500 & 13.6450 \\
\hline & 5 & 1,761 & 39.8300 & 41.7400 & 9.4300 \\
\hline & 6 & 1,762 & 91.0000 & 60.6000 & 12.8350 \\
\hline 30 & 1 & 1,756 & 0 & 1.6200 & 12.7325 \\
\hline 40 & 1 & 1,736 & 0 & .1900 & .2350 \\
\hline
\end{tabular}


Table 4. Zonal elevation base and regression coefficients for elevation-volume-area relations of selected control ponds at Quivira National Wildlife Refuge-Continued

\begin{tabular}{|c|c|c|c|c|c|}
\hline \multirow{2}{*}{$\begin{array}{l}\text { Water-unit } \\
\text { number } \\
\text { (fig. 2) }\end{array}$} & \multirow[b]{2}{*}{ Zone number } & \multirow{2}{*}{$\begin{array}{c}\text { Zonal elevation } \\
\text { base, } Z_{b} \\
\text { (feet above sea } \\
\text { level) }\end{array}$} & \multicolumn{3}{|c|}{ Regression coefficients } \\
\hline & & & A1 & A2 & A3 \\
\hline \multirow[t]{3}{*}{40} & 2 & 1,738 & 1.4400 & 1.2500 & 2.2725 \\
\hline & 3 & 1,740 & 13.0300 & 10.3400 & 4.3375 \\
\hline & 4 & 1,742 & 51.0600 & 27.6900 & 4.4375 \\
\hline \multirow[t]{5}{*}{48} & 1 & 1,750 & 0 & .2700 & .4750 \\
\hline & 2 & 1,751 & .7450 & 1.2200 & 2.1400 \\
\hline & 3 & 1,752 & 4.1050 & 5.5000 & 14.3300 \\
\hline & 4 & 1,753 & 23.9350 & 34.1600 & 21.3150 \\
\hline & 5 & 1,754 & 79.4100 & 76.7900 & 15.6400 \\
\hline \multirow[t]{4}{*}{49} & 1 & 1,750 & 0 & .4600 & 1.6450 \\
\hline & 2 & 1,751 & 2.1050 & 3.7500 & 11.2350 \\
\hline & 3 & 1,752 & 17.0900 & 26.2200 & 19.3450 \\
\hline & 4 & 1,753 & 62.6550 & 64.9100 & 12.4750 \\
\hline \multirow[t]{2}{*}{57} & 1 & 1,740 & 0 & 5.5300 & 14.5825 \\
\hline & 2 & 1,742 & 69.3900 & 63.8600 & 20.9075 \\
\hline \multirow[t]{3}{*}{58} & 1 & 1,736 & 0 & 2.2800 & 3.9775 \\
\hline & 2 & 1,738 & 20.4700 & 18.1900 & 9.5700 \\
\hline & 3 & 1,740 & 95.1300 & 56.4700 & 10.6425 \\
\hline \multirow[t]{2}{*}{61} & 1 & 1,740 & 0 & 10.2900 & 6.9975 \\
\hline & 2 & 1,742 & 48.5700 & 38.2800 & 25.7175 \\
\hline \multirow[t]{8}{*}{62} & 1 & 1,735 & 0 & .0100 & .1000 \\
\hline & 2 & 1,736 & .1100 & .2100 & .1900 \\
\hline & 3 & 1,737 & .5100 & .5900 & .3150 \\
\hline & 4 & 1,738 & 1.4150 & 1.2200 & 1.0550 \\
\hline & 5 & 1,739 & 3.6900 & 3.3300 & 2.4350 \\
\hline & 6 & 1,740 & 9.4550 & 8.2000 & 5.4750 \\
\hline & 7 & 1,741 & 23.1300 & 19.1500 & 4.0800 \\
\hline & 8 & 1,742 & 46.6360 & 27.3100 & 4.8150 \\
\hline \multirow[t]{3}{*}{63} & 1 & 1,736 & 0 & .3800 & 6.0175 \\
\hline & 2 & 1,738 & 24.8300 & 24.4500 & 24.6250 \\
\hline & 3 & 1,740 & 172.2300 & 122.9500 & 13.0675 \\
\hline \multirow[t]{5}{*}{75} & 1 & 1,736 & 0 & .3100 & 96.7650 \\
\hline & 2 & 1,737 & 97.0750 & 193.8400 & 84.3200 \\
\hline & 3 & 1,738 & 375.2350 & 362.4800 & 76.1350 \\
\hline & 4 & 1,739 & 813.8500 & 514.7500 & 113.3850 \\
\hline & 5 & 1,740 & $1,441.9851$ & 741.5198 & 641.6354 \\
\hline
\end{tabular}


resented by stepwise regression equations in terms of zonal water depth (Megan, Estep-Johnston, U.S. Fish and Wildlife, written commun., 1995):

$$
\begin{gathered}
V=A 1+A 2 \mathrm{X}+A 3 X^{2}, \text { and } \\
A=A 2+(A 3+A 3) \mathrm{X},
\end{gathered}
$$

where $X$ is the zonal water depth and is equal to the difference between pond water-surface elevation $(Z)$, in feet, and the corresponding zonal elevation base $\left(Z_{b}\right)$, in feet; that is, $X=Z-Z_{b} . A 1, A 2$, and $A 3$ are regression coefficients, volume $(V)$ is in acre-feet, and water-surface area $(A)$ is in acres.

Table 4 summarizes the zonal elevation bases and corresponding regression coefficients of selected control ponds (Megan Estep-Johnston, U.S. Fish and Wildlife Service, written commun. 1995).

As an illustration of the use of these regression equations, consider water unit 5 as an example. Let the water-surface elevation $Z$ be $1,782.5 \mathrm{ft}$. From table 4, the water surface is located in zone 2 because the water-surface elevation of $1,782.5 \mathrm{ft}$ is higher than the zonal elevation base $\left(Z_{b}\right)$ of $1,782 \mathrm{ft}$. Therefore, the zonal water depth $(X)$ is $1,782.5-1,782.0=0.5 \mathrm{ft}$ with the regression coefficients $(A 1, A 2$, and $A 3)$ of $1,059.0999,749.9802$, and 56.9399, respectively. Using equations 1 and 2 , the corresponding water volume $(V)$ and water-surface area $(A)$ are $1,448.32$ acre-ft and 806.92 acres, respectively. However, if the water-surface elevation $Z$ is $1,781.0 \mathrm{ft}$, the corresponding zone number now is 1 with a zonal elevation base $\left(Z_{b}\right)$ of $1,780 \mathrm{ft}$ and regression coefficients $(A 1, A 2$, and $A 3$ ) of $1.0000,308.1200$, and 110.4650 , respectively. Therefore, the corresponding water volume $(V)$ and water-surface area $(A)$ are 419.59 acre-ft and 529.05 acres, respectively. Figure 3 shows the elevation-volume-area curves for Little Salt Marsh (water unit 5, fig. 2) using equations 1 and 2.

\section{LINEAR-NETWORK FLOW MODEL}

The optimal operation of the control ponds at the Quivira National Wildlife Refuge can be formulated mathematically as a linear-network flow problem (Jian, 1988; Yu and others, 1989). In this section, the mathematical formulation of a linear-network flow model (Jian, 1988) is modified and expanded. The concepts of a rule curve for a pond and the zoning of pond storage and canal flow are introduced in this section. These two concepts are bases for formulating a network flow problem. The operating policy for a pond system in terms of priority and cost-penalty coefficients is also discussed. By combining the concepts of a rule curve and zoning and the operating policy, the problem of the operation of pond storage and flow routing can be formulated as a minimum-cost network flow problem, which is a typical topic in network flow analysis.

\section{Network Representation of Flow Systems}

To apply network flow analysis to the Quivira National Wildlife Refuge, the flow systems shown in figure 2 were conceptually represented by a network of nodes and arcs (fig. 4). The network was comprised of 67 nodes, of which 34 nodes are pond nodes (oval shape in fig. 4). Water unit 55 was shown as an oval in figure 4 and treated as a canal node because there was no pond information for that unit. Ninety-seven (97) arcs were used to represent canals or waterways on the refuge. Water unit 34 in figure 4 is a proposed pond for future use and is not currently (1997) in operation.

\section{Rule-Curve and Zoning Concepts}

A rule curve designated a target water level in a control pond. Using the zoning concept, a control pond at the refuge was divided into four storage zones-extended upper zone, upper zone, lower zone, and inactive zone-and the rule curve was set at the top of the lower zone (fig. 5). The extended upper zone was used during periods of flood. The upper zone and lower zone were called conservation zones and were used to represent normal use. The inactive zone represented the storage area filled up by sediment accumulation. The selection of the number of zones in a particular pond was based on management needs. For example, if the objective of management was to maximize water yields, the target water level (that is, rule curve) was set at the highest elevation of a pond so that high water levels could be maintained after satisfying downstream flow requirements and water demands.

Similarly, flow in a canal was also divided into an upper zone (that is, above-normal zone), a normal zone, and a lower zone (that is, below-normal zone) as shown in figure 6. The selection of the number of canal flow zones was also dependent on management needs. 


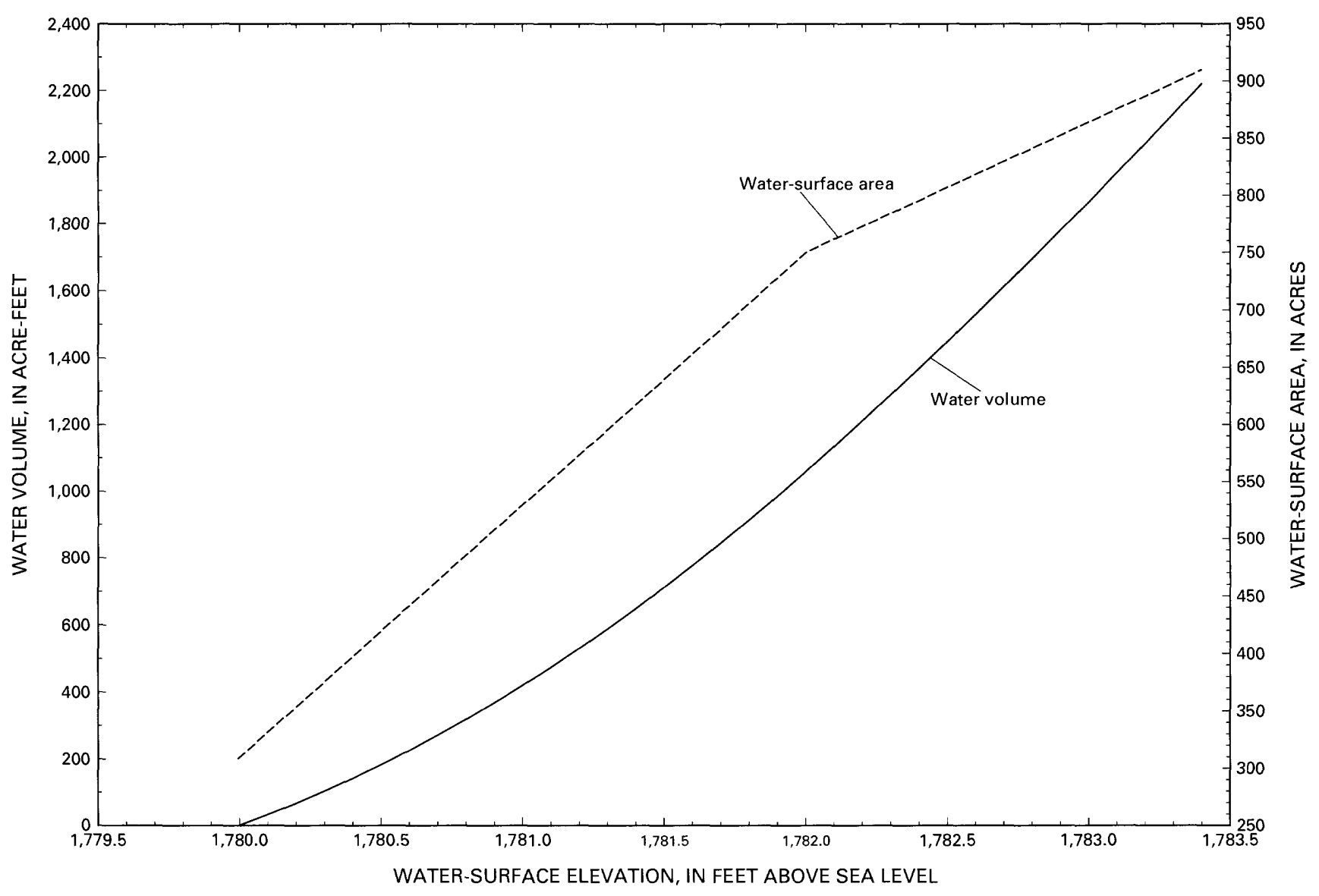

Figure 3. Relations of water-surface elevation, water volume, and water-surface area for Little Salt Marsh (water unit 5, fig. 2).

Because flows in canals at the refuge are not regulated, one flow zone (normal) was used in the flow model development. In model simulations, canal flows were maintained in the normal flow zone as long as possible.

\section{Operating Policy}

Under ideal inflow conditions, all pond levels would be maintained at the target water levels (rule curves), and all canal flows would be maintained in the normal flow ranges in addition to satisfying water-management requirements such as minimum desirable streamflow (Kansas Water Office, written commun., 1996). In reality, ideal inflow conditions rarely occur. If a pond water level was higher or lower than its rule curve, a "cost" or "penalty" was assessed to the water storage or depletion deviation from the rule curve. The penalty depended on the amount of water deviation from the target level and the penalty coefficient (cost per unit water deviation from the target level). A penalty was also assessed to canal flows. In other words, penalty coefficients were assigned to each storage zone of a pond and each flow zone in a canal to assess penalty.

Different penalty coefficients were assigned according to management priorities related to each storage zone of a pond. Penalty coefficients for canal flows were specified in a similar way. Higher penalty coefficients were assigned to the extended upper zone and inactive zone, and smaller penalty coefficients were assigned to the conservation zone (the lower zone and the upper zone) because water levels needed to be maintained in the conservation zone for normal use. The penalty coefficient in the normal-flow zone in a canal was generally zero or less than the penalty coefficient of the pond conservation zone. A higher penalty coefficient was assigned for violation of normal flow range; that is, the higher values of penalty coefficients were assigned to the upper and lower flow zones.

To optimally operate the canal and pond system at the refuge, it was necessary for some interpond rela- 


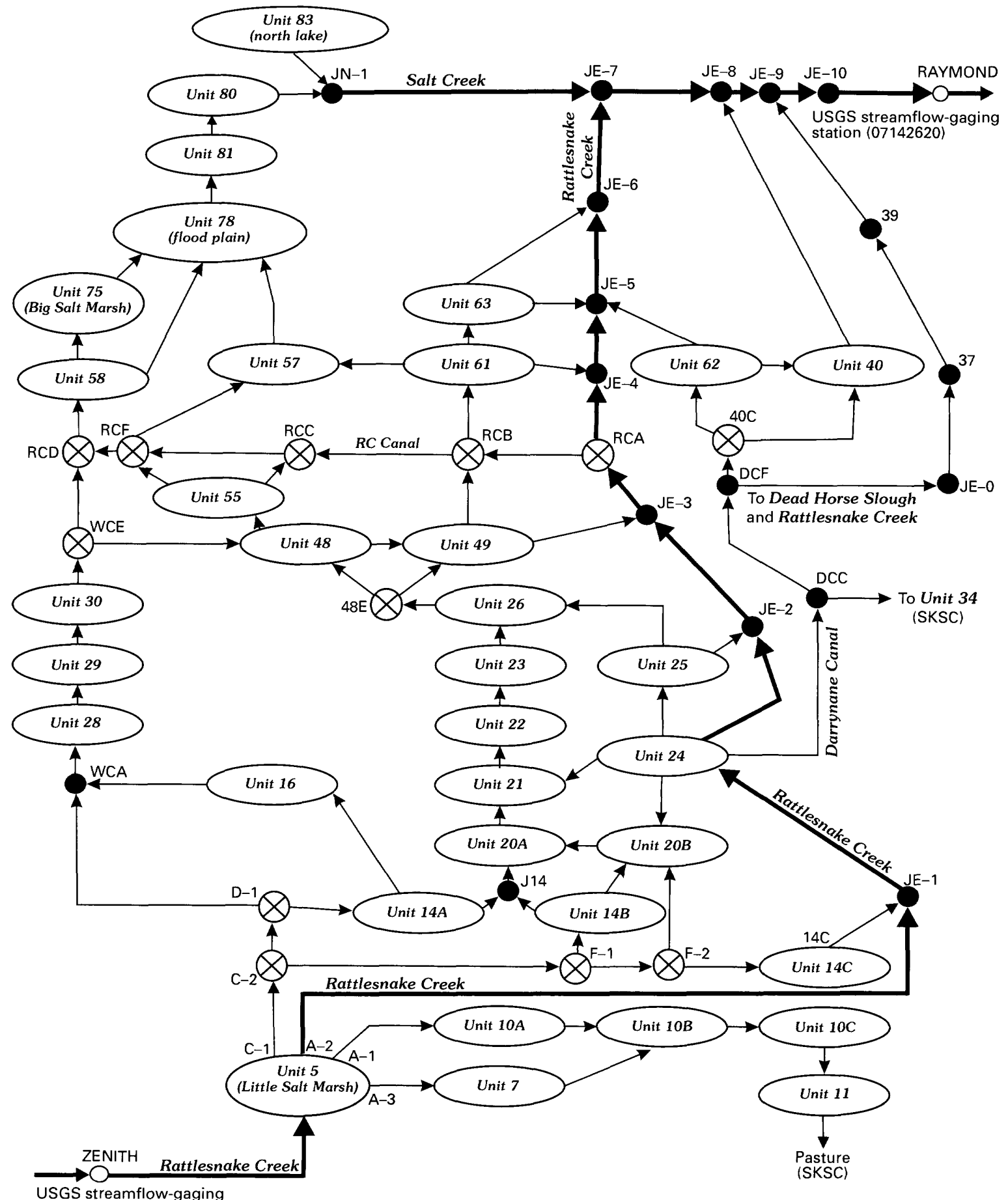

USGS streamflow-gaging

station $(07142575)$

\section{EXPLANATION}

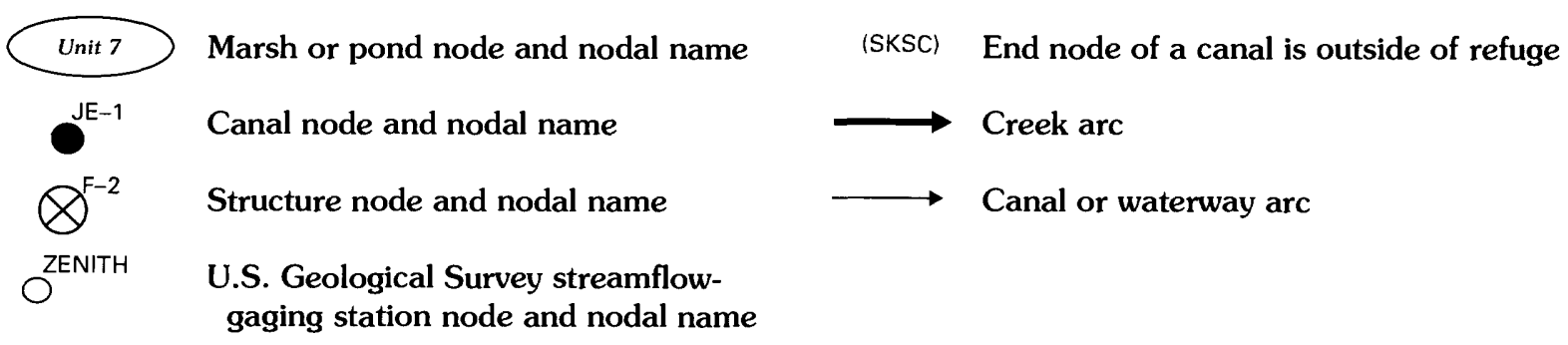

Figure 4. Network representation of flow systems at Quivira National Wildlife Refuge. 


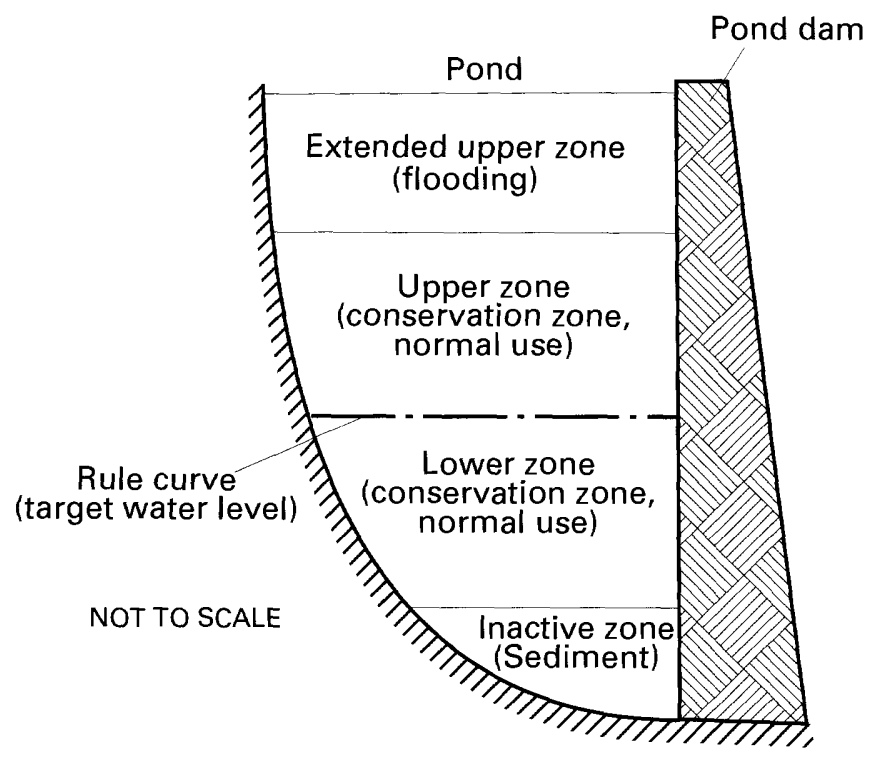

Figure 5. Concepts of rule curve and pond zoning.

tions to be incorporated into the flow model. One of the relations was priority ranking of the ponds. Ponds were ranked according to some specified criteria by assigning different penalty coefficients to storage zones. The lowest priority pond was assigned the smallest penalty coefficient for the same-purpose storage zone; higher priority ponds had higher penalty coefficients. Using this relation, violation of the rule curve first occurred in the pond with the lowest priority. It was common for rule-curve violations to occur first in the downstream ponds rather than the upstream ones. This procedure minimized unnecessary spilling at the most downstream pond in the event of high lateral flows; that is, flows that did not enter the system through upstream ponds. The optimal operation of the canal and pond system minimized the total penalty assessed on the deviations of pond storage from the rule curve and of canal flows from specified normal flows.

\section{Mathematical Expression of Linear-Network Flow Model}

The flow network consisted of nodes and directed arcs. A node represented a location where the computation of the water budget was needed, such as at ponds and at canals where diversion of water occurred. An arc represented a stream or a canal along which water moved from one location to another. An arc was also used to represent a storage deviation of a pond or canal,

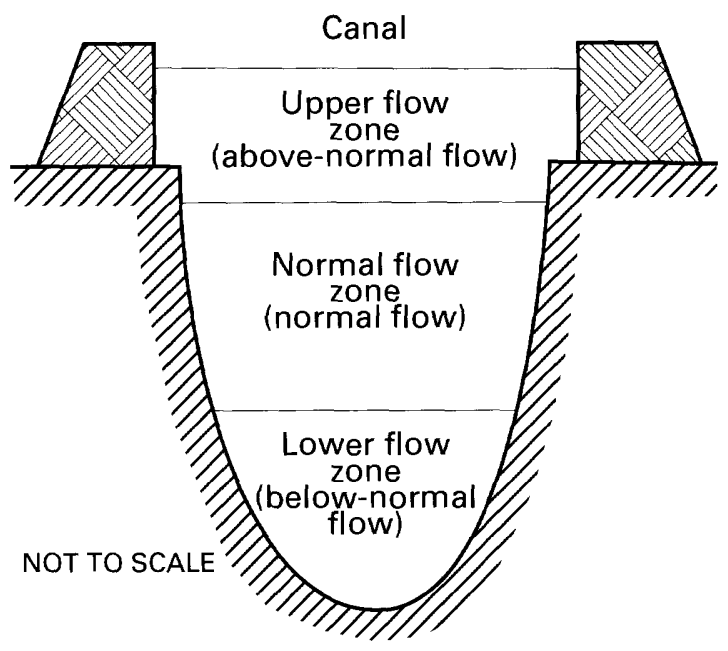

Figure 6. Concepts of canal-flow zoning.

and other additional contributions such as evaporation, seepage, and runoff.

The linear-network flow model was expressed mathematically as a linear programming problem of minimizing the total cost or penalty as follows:

$$
\text { Minimize } \sum_{i} \sum_{j} C_{i j} Q_{i j} \text { for all }(i, j) \text { arcs, }
$$

subject to $\sum_{j} Q_{j i}-\sum_{j} Q_{i j}=0$ for all $\mathrm{i}$ nodes, and

$$
L_{i j} \leq Q_{i j} \leq U_{i j} \text { for all }(\mathrm{i}, \mathrm{j}) \text { arcs }
$$

where

$Q_{i j}=$ flow in $\operatorname{arc}(i, j)$ from node $i$ to node $j$;

$C_{i j}=$ cost per unit flow in $\operatorname{arc}(i, j)$, also called the penalty coefficient;

$L_{i j}=$ the lower flow boundary in any arc $(i, j)$; and

$U_{i j}=$ the upper flow boundary in any $\operatorname{arc}(i, j)$.

Any flow (choice of the $Q_{i j}$ 's) satisfying the constraints in equation 4 was called a conserving flow, accounting for mass conservation at the nodes. A conserving flow that satisfied the remaining constraints in equation 5 was a feasible flow (solution).

The objective of equation 3 for the operation of canals and control ponds was to minimize the total cost due to deviations from specified rule curves and canal flows. Equations 3-5 needed to incorporate the con- 


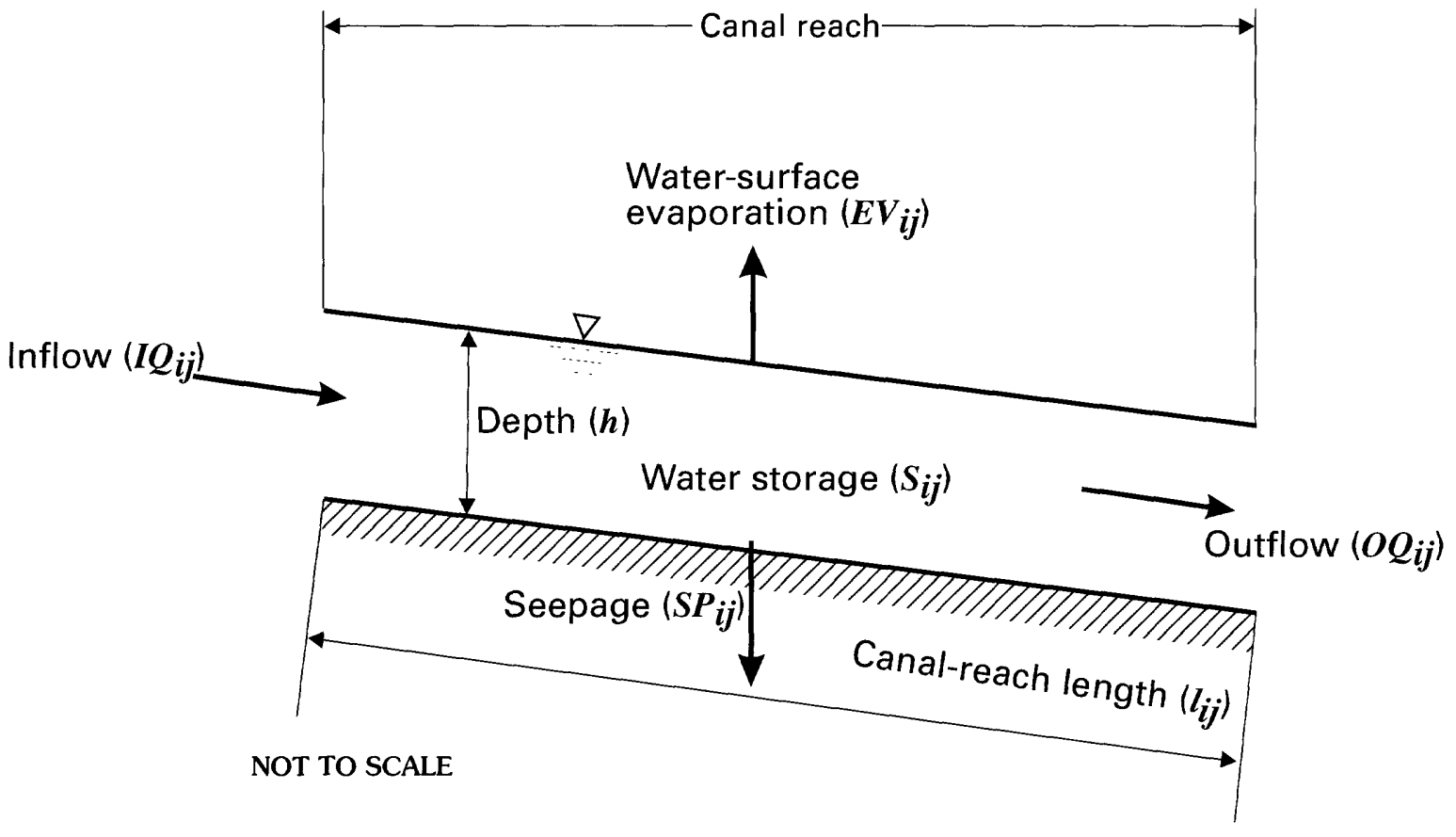

A. Water balance in a canal reach

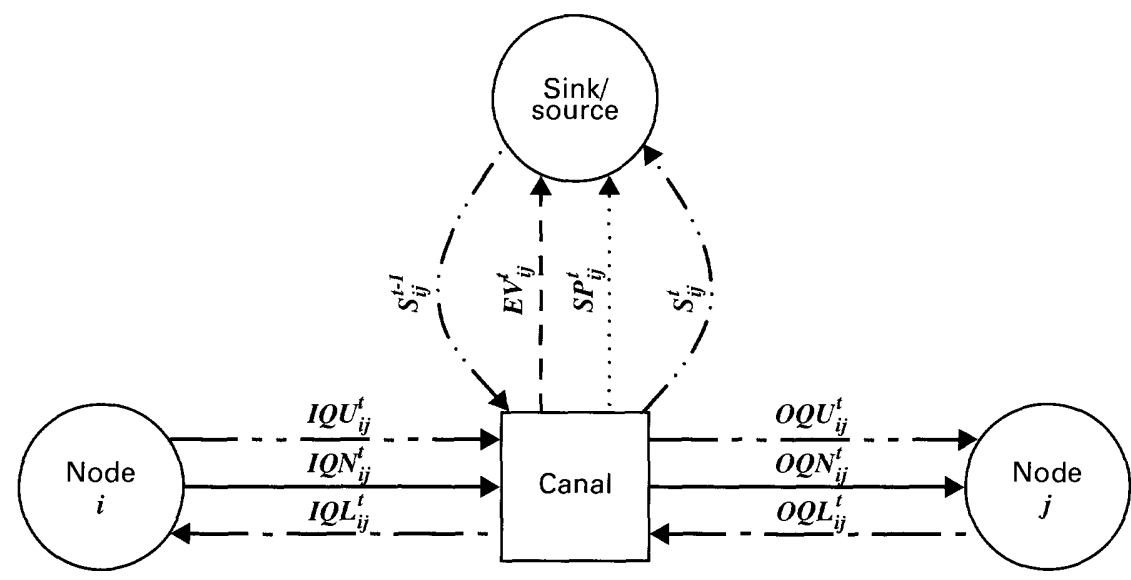

NOT TO SCALE

EXPLANATION

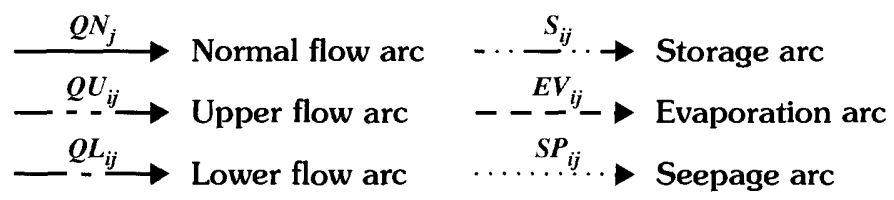

B. Arc-node representation of canal-flow routing

Figure 7. (A) Water balance in a canal reach and (B) arc-node representation of canal-flow routing. 
cepts of rule curve and zoning to obtain the appropriate water-balance equation for any pond or canal reach.

\section{Canal Routing}

Considering a canal reach $(i, j)$ with a length $l_{i j}$, the water balance in the canal (fig. $7 A$ ) during time period $(t)$ was expressed as:

$$
I Q_{i j}{ }^{t}-O Q_{i j}{ }^{t}-\left(S P_{i j}{ }^{t}+E V_{i j}{ }^{t}\right)=S_{i j}{ }^{t}-S_{i j}{ }^{t-1},
$$

where

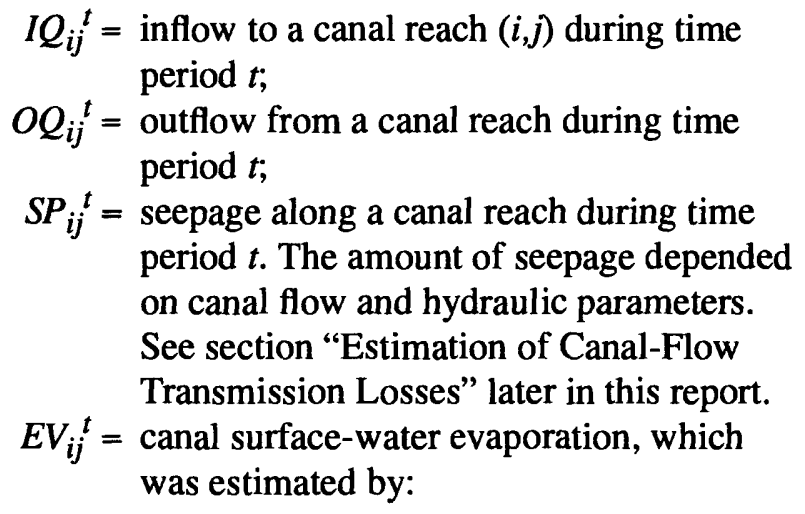

$$
E V_{i j}{ }^{t}=e_{i j}{ }^{t} A_{i j}{ }^{t}
$$

in which $e_{i j}{ }^{t}$ was the water-surface evaporation coefficient for time period $t$, and $A_{i j}{ }^{t}$ was the water-surface area given by $A_{i j}{ }^{t}=l_{i j} b_{i j}$, where $l_{i j}$ and $b_{i j}$ were the canal length and the width of the water surface, respectively.

$S_{i j}{ }^{t}=$ water storage in a canal reach at the end of time period $t$. Canal storage $S_{i j}{ }^{t}$ depended on canal inflow and outflow, and canal hydrologic parameters. See section "Estimation of Canal Water Storage" using Muskingum's method (McCuen, 1989) later in this report.

$S_{i j}{ }^{t-1}=$ water storage in a canal reach at the beginning of time period $t$.

In the concept of canal-flow zoning, canal flow may be in the normal, upper, or lower flow zone. The actual flow in a canal was denoted by $Q$ and the normal flow by $Q N$. The range of flow in the normal flow zone was $0 \leq Q N \leq Q N \leq \overline{Q N}$, where $Q N$ and $\overline{Q N}$ were the lower and upper boundaries of the normal flow range, respectively. If canal flow $(Q)$ was in the upper flow zone, then the upper flow $(Q U)$ was defined as the flow deviation from the upper boundary of the normal flow range; that is, $Q U=Q-\overline{Q N}$, and $0 \leq Q U \leq \overline{Q U}$, where $\overline{Q U}$ was the magnitude of the upper flow zone. In this case, $Q N=\overline{Q N}$, and $Q=Q N$ $+Q U$. If canal flow $(Q)$ was in the lower flow zone, then the lower flow $(Q L)$ was defined as the flow deviation from the lower boundary of the normal flow zone; that is, $Q L=Q N-Q$, and $0 \leq Q L \leq \overline{Q L}$, where $\overline{Q L}$ was the magnitude of the lower flow zone. In this case, $Q N=Q N$, and $Q=Q N-Q L$. Therefore, the actual flow $Q$ in a canal reach could be expressed as normal flow $(Q N)$, plus the upper flow $(Q U)$, and minus the lower flow $(Q L)$; that is,

$$
Q=Q N+Q U-Q L
$$

If canal flow was in the normal flow zone, both $Q U$ and $Q L$ were equal to zero. If canal flow was in the upper zone, $Q L$ was zero. On the other hand, if canal flow was in the lower flow zone, $Q U$ was zero. Therefore, equation 8 represented all flow states in a canal.

Substituting equation 8 into equation 6 gave the canal water-balance equation as follows:

$$
\begin{aligned}
& \left(I Q N_{i j}{ }^{t}+I Q U_{i j}{ }^{t}-I Q L_{i j}{ }^{t}\right)-\left(O Q N_{i j}{ }^{t}+O Q U_{i j}{ }^{t}-O Q L_{i j}{ }^{t}\right)- \\
& \left(S P_{i j}{ }^{t}+E V_{i j}{ }^{t}\right)=S_{i j}{ }^{t}-S_{i j}^{t-1},
\end{aligned}
$$

where

$$
\begin{aligned}
I Q N_{i j}{ }^{t}= & \text { normal inflow }\left(0 \leq \underline{Q N}_{i j} \leq I Q N_{i j}^{t} \leq \overline{Q N}_{i j}\right), \\
I Q U_{i j}{ }^{t}= & \text { upper inflow }\left(0 \leq I Q U_{i j}^{t} \leq \overline{Q U}_{i j}\right) \\
I Q L_{i j}{ }^{t}= & \text { lower inflow }\left(0 \leq I Q L_{i j}^{t} \leq \overline{Q L}_{i j}\right) \\
O Q N_{i j}{ }^{t}= & \text { normal outflow } \\
& \left(0 \leq \underline{Q N}_{i j} \leq O Q N_{i j}^{t} \leq \overline{Q N}_{i j}\right) \\
O Q U_{i j}{ }^{t}= & \text { upper outflow }\left(0 \leq O Q U_{i j}^{t} \leq \overline{Q U}_{i j}\right), \text { and } \\
O Q L_{i j}{ }^{t}= & \text { lower outflow }\left(0 \leq O Q L_{i j}^{t} \leq \overline{Q L}_{i j}\right) .
\end{aligned}
$$

Each item in equation 9 could be represented by flow through a distinct arc (fig. 7B). If there was no water loss or storage change along the arc $(i, j)$, then the actual flow between two neighboring nodes $i$ and $j$ was simplified as:

$$
I Q_{i j}{ }^{t}=O Q_{i j}{ }^{t}=I Q N_{i j}{ }^{t}+I Q U_{i j}{ }^{t}-I Q L_{i j}{ }^{t}
$$




\section{Pond-Storage Routing}

Using the concepts of rule curve and zoning of a pond, the actual storage of a pond $i$ at time $t, S_{i}{ }^{t}$, was represented as the sum of the rule-curve storage, $R C_{i}{ }_{i}$, plus the storage deviation from the rule-curve storage, $D_{i}^{t}$; that is,

$$
S_{i}^{t}=R C_{i}^{t}+D_{i}^{t}
$$

where

subscript $i$ was the pond node index, and

superscript $t$ was the time period index.

In the concept of pond zoning, the storage deviation, $D_{i}{ }_{i}$, was expressed as:

$$
D_{i}^{t}=S U_{i}^{t}-S L_{i}^{t}
$$

where

$S U_{i}^{t}=$ the actual storage deviation above the rule curve in the upper zone; that is, $S U_{i}{ }^{t}=S_{i}{ }^{t}$ $R C_{i}{ }_{i}$, and $0 \leq S U_{i}^{t} \leq \overline{S U}_{i}$, where $\overline{S U}_{i}$ was the total capacity of the upper zone in control pond $i$. If there were $m$ upper zones, the upper deviation $S U_{i}^{t}$ was calculated by:

$$
S U_{i}^{t}=\sum_{k=1}^{m} S U_{i, k}^{t},
$$

where

$S U_{i, k}^{t}$ was the water storage in the upper zone $k$. $S L_{i}{ }^{t}=$ the actual storage deviation from the rule curve in the lower zone; that is, $S L_{i}{ }^{t}=R C_{i}{ }^{t}$ - $S_{i}{ }^{t}$, and $0 \leq S L_{i}^{t} \leq \overline{S L}_{i}$, where $\overline{S L}_{i}$ was the total capacity of the lower zone in pond $i$. If there were $n$ lower zones, the lower deviation $S L_{i}{ }^{t}$ was calculated by:

$$
S L_{i}^{t}=\sum_{k=1}^{n} S L_{i, k}^{t}
$$

where

$S L_{i, k}^{t}$ was the water storage in the lower zone $k$. Only one of the two terms on the right side of equation 12 could be nonzero. In other words, if the pond water level was in the upper zone, then $S L_{i}{ }^{t}=0$. On the other hand, if the pond water level was in the lower zone, then $S U_{i}^{t}=0$.

Substituting equation 12 into equation 11 gave:

$$
S_{i}^{t}=R C_{i}^{t}+S U_{i}^{t}-S L_{i}^{t}
$$

The water-balance equation (equation 3 ) for pond node $i$ could then be rewritten as:

$$
\sum_{j} O Q_{j i}^{t}-\sum_{j} I Q_{i j}^{t}+I_{i}^{t}+R N_{i}^{t}-E V_{i}^{t}-S P_{i}^{t}-W_{i}^{t}=S_{i}^{t}-S_{i}^{t-1},
$$

where

$O Q_{j i}{ }^{t}=$ canal inflow from the upstream node $j$ during time period $t$.

$I Q_{i j}{ }^{t}=$ water release to downstream node $j$ during time period $t$. Release was determined in terms of a downstream flow requirement, pond stage, and outlet control structure. See section "Flow Through Hydraulic Structures" later in this report.

$I_{i}{ }^{t}=$ local net inflow to pond $i$ during time period $t$.

$R N_{i}^{t}=$ precipitation falling onto the water surface $\left(P_{i}{ }^{t}\right)$ plus the direct overland surface runoff $\left(R F_{i}{ }^{t}\right)$ during time period $t$, given by:

$$
R N_{i}^{t}=P_{i}^{t}+R F_{i}^{t}
$$

Precipitation falling onto the water surface, in acre-feet, $P_{i}{ }_{i}$, was estimated by:

$$
P_{i}^{t}=0.0833 r_{i}^{t} A_{i}^{t},
$$

in which $r_{i}^{t}$ was rainfall during time period $t$, in inches, and $A_{i}{ }^{t}$ was the water-surface area, in acres. Direct overland surface runoff $\left(R F_{i}{ }^{\dagger}\right)$ was estimated using a SCS curve-number method (Soil Conservation Service, 1985). See section "Estimation of Direct Overland Surface Runoff" later in this report.

$E V_{i}^{t}=$ water-surface evaporation of pond $i$ during time period $t$ was estimated by:

$$
E V_{i}^{t}=e_{i}^{t} A_{i}^{t}
$$


in which $e_{i}^{t}$ was the water-surface evaporation coefficient for time period $t$, and $A_{i}{ }^{t}$ was the pond water-surface area at the beginning of time period $t$. If the evaporation rate $a_{i}{ }^{t}$ was in inches per day and the water-surface area $A_{i}{ }^{t}$ was in acres, then total surface evaporation $E V_{i}^{t}$, in acre-feet, during time period $t$ with time length of $\Delta t$ days was calculated as follows:

$$
E V_{i}^{t}=0.0833 a_{i}^{t} A_{i}^{t} \Delta t
$$

$S P_{i}{ }^{t}=$ seepage through the pond bottom, in acre-feet. Seepage was estimated using Darcy's equation:

$$
S P_{i}^{t}=K_{i} \frac{Z s w_{i}^{t}-Z g w_{i}^{t}}{d_{i}} A_{i}^{t} \Delta t
$$

in which $K_{i}$ was the bottom hydraulic conductivity of pond $i$, in feet per day; $Z s w_{i}^{t}$ was the surface-water elevation, in feet above sea level; $Z g w_{i}{ }^{t}$ was the groundwater elevation below the pond bottom, in feet above sea level; and $d_{i}$ was the pond-bottom thickness, in feet.

$W_{i}^{t}=$ water withdrawal during time period $t$, in acre-feet.

$S_{i}^{t}=$ pond storage at the end of time period $t$, in acre-feet.

$\mathrm{S}_{\mathrm{i}}^{\mathrm{t}-1}=$ pond storage at the beginning of time period $t$, in acre-feet.

Substituting equations 8 and 15 into equation 16 gave:

$$
\begin{gathered}
\sum_{j}\left(O Q N_{j i}^{t}+O Q U_{j i}^{t}-O Q L_{j i}^{t}\right)-\sum_{j}\left(I Q N_{i j}^{t}+I Q U_{i j}^{t}-I Q L_{i j}^{t}\right)+ \\
I_{i}^{t}+R N_{i}^{t}-S P_{i}^{t}-W_{i}^{t}=\left(R C_{i}^{t}+S U_{i}^{t}\right)-s_{i}^{t-1} .
\end{gathered}
$$

Rearranging equation 22 gave:

$$
\begin{gathered}
\sum_{j}\left(O Q N_{j i}^{t}+O Q U_{j i}^{t}-O Q L_{j i}^{t}\right)- \\
\sum_{J}\left(I Q N_{i j}^{t}+I Q U_{i j}^{t}-I Q L_{i j}^{t}\right)-S U_{i}^{t}+S L_{i}^{t} \\
+\left(S_{i}^{t-1}+I_{i}^{t}+R N_{i}^{t}-R C_{i}^{t}-S P_{i}^{t}-E V_{i}^{t}-W_{i}^{t}\right)=0
\end{gathered}
$$

At the beginning of time $t$, the values of $S_{i}^{t-1}, I_{i}^{t}, R N_{i}^{t}$, $R C_{i}^{t}, S P_{i}^{t}, E V_{i}^{t}$, and $W_{i}^{t}$ were known or could be estimated using previous time-period data. If $N V_{i}^{t}=S_{i}^{t-1}+$ $I_{i}{ }^{t}+R N_{i}{ }^{t}-R C_{i}{ }^{t}-S P_{i}{ }^{t}-E V_{i}{ }^{t}-W_{i}{ }^{t}$, the pond waterbalance equation became:

$$
\begin{gathered}
\sum_{j}\left(O Q N_{j i}^{t}+O Q U_{j i}^{t}-O Q L_{j i}^{t}\right)- \\
\sum_{j}\left(I Q N_{i j}^{t}+I Q U_{i j}^{t}-I Q L_{i j}^{t}\right)-S U_{i}^{t}+S L_{i}^{t}+N V_{i}^{t}=0
\end{gathered}
$$

Each term in equation 24 was represented by flow through a distinct arc in the linear-network flow model. Among these arcs, the term $N V_{i}^{t}$ was simply called a net-value arc $(N V)$. Upper storage deviation $\operatorname{arcs}(S U)$, lower storage deviation arcs $(S L)$, and $N V$ arcs were connected to a sink/source node (fig. 8). The direction of $S U$ arcs was from node $i$ to the sink/source node. The direction of $S L$ arcs was from the sink/source node to node $i$. The direction of $N V$ arcs depended on the sign of the value of $N V_{i}^{t}$. If the value of $N V_{i}^{t}$ was positive, the direction of the $N V$ arc was from the sink/source node to the pond node $i$, and the reverse was true if the value of $N V_{i}^{t}$ was negative (fig. 8).

\section{General Node}

A general node was designated where the calculation of water balance was needed (for example, at joints of canals). The difference between a pond node and a general node was that there was no water storage associated with a general node. The water balance at general node $i$ during time $t$ was given by:

$$
\sum_{j} O Q_{j i}^{t}-\sum_{j} I Q_{i j}^{t}+I_{i}^{t}-W_{i}^{t}=0
$$

where

$$
\begin{aligned}
& O Q_{j i}{ }^{t}=\text { inflow from upstream node } j \text { to node } i \text { dur- } \\
& W_{i}^{t}=T R_{i}^{t}-D W_{i}^{t}
\end{aligned}
$$




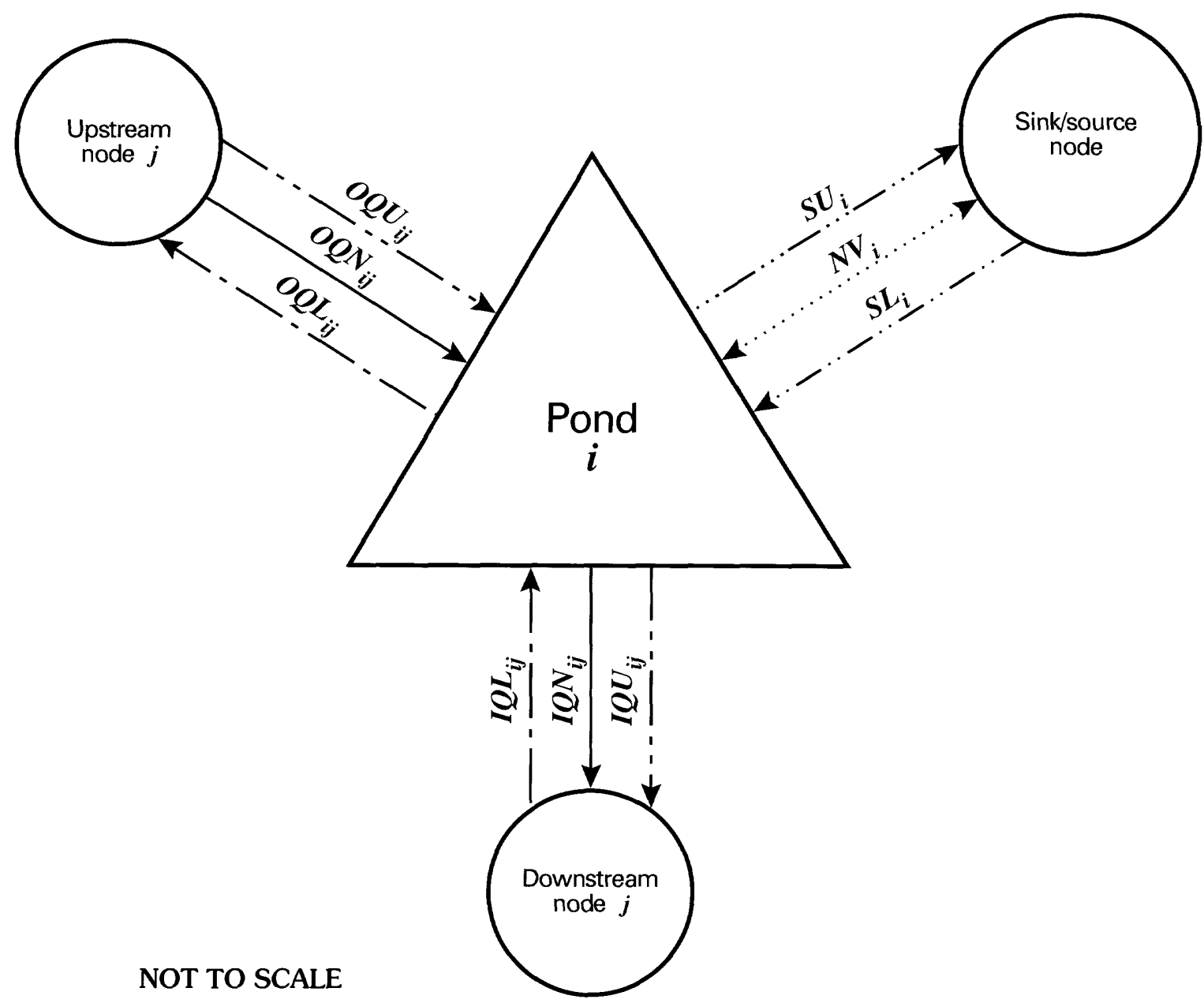

EXPLANATION

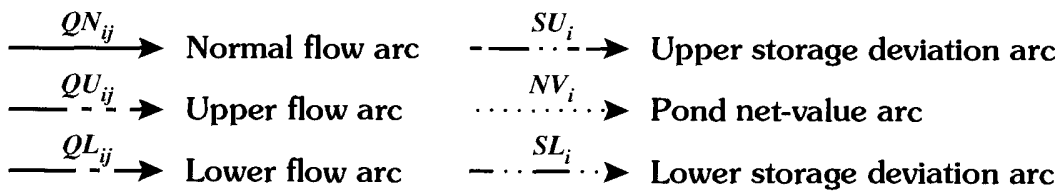

Figure 8. Arc-node representation for pond-storage routing.

in which $T R_{i}{ }^{t}$ was the target water-withdrawal from node $i$ during time period $t$, and $D W_{i}^{t}$ was the water withdrawal deviation for node $i$ during time period $t$, $0 \leq D W_{i}^{t} \leq T R_{i}^{t}$.

Substituting equations 8 and 26 into equation 25 gave:

$$
\begin{gathered}
\sum_{j}\left(O Q N_{j i}^{t}+O Q U_{j i}^{t}-O Q L_{j i}^{t}\right)- \\
\sum_{j}\left(I Q N_{i j}^{t}+I Q U_{i j}^{t}-I Q L_{i j}^{t}\right)+I_{i}^{t}-\left(T R_{i}^{t}-D W_{i}^{t}\right)=0 .
\end{gathered}
$$

Equation 27 is consistent with equation 4, and each term of equation 27 was represented by flow through a distinct arc (fig. 9). Among flows through these arcs, flows $I_{i}{ }^{t}$ and $T R_{i}{ }^{t}$ were known at the beginning of time $t$. The direction of the $I_{i}{ }^{t}$ arc depended on the sign of the value $I_{i} t$. If it was positive, then the arc was directed toward the water demand node from the sink/source node. The reverse was true for a negative $I_{i}{ }^{t}$. Because $I_{i}{ }^{t}$ and $T R_{i}{ }^{t}$ were known, the penalty coefficients of $I_{i}{ }^{t}$ and $T R_{i}{ }^{t}$ arcs were assigned to be zero. 


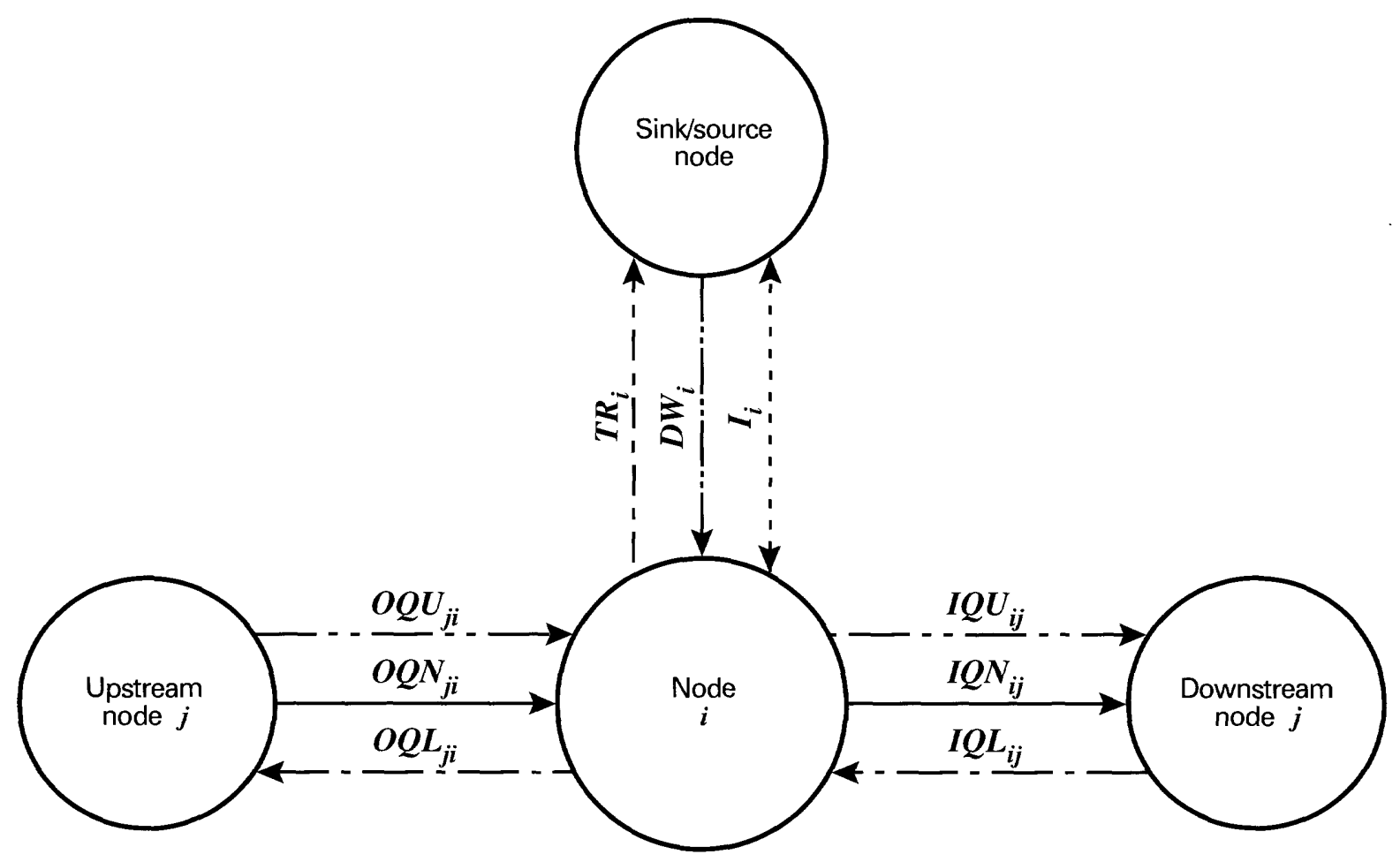

NOT TO SCALE

\section{EXPLANATION}

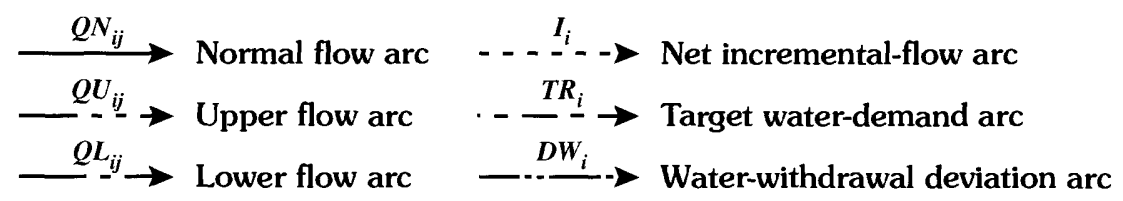

Figure 9. Arc-node representation for a general node.

\section{Sink/Source Node}

The sink/source node mentioned in previous sections was an introduced node that made it possible to form a closed-loop network. As a sink, this node accounted for: (1) flows from canal water loss (seepage and evaporation) and final water storage (fig. $7 B$ ), (2) flows from the storage deviation above the rule curve (fig. 8), (3) canal flows at the downstream end of the system, and (4) water withdrawal from a node (fig. 9). As a source, the sink/source node accounted for: (1) flows for the canal initial storages (fig. 7B), (2) flows for the storage deviations below the rule curves (fig. 8), (3) net inflows to ponds (fig. 8), and (4) net incremental flows to general nodes (fig. 9). The water balance for canal reaches, pond nodes, and general nodes guaranteed that mass conservation at a sink/source node was satisfied.

\section{Linear-Network Optimization Flow Model}

The linear-network flow model given by equations 3-5 was rewritten for the operation of canals and control ponds as follows:

Minimize

$$
\sum_{i}\left(C_{i}^{u} S U_{i}+C_{i}^{l} S L_{i}\right)^{t}+
$$

$\sum_{i} \sum_{j}\left(C_{i j}^{n} Q N_{i j}+C_{u h}^{u} Q U_{i j}-C_{i j}^{l} Q L_{i j}\right)^{t}+\sum_{i} C_{i}^{w} D W_{i}^{t}$,

subject to 


$$
\begin{gathered}
\sum\left(O Q N_{j i}+O Q U_{j i}-O Q L_{j i}\right)^{t}- \\
\sum_{j}\left(I Q N_{i j}+I Q U_{i j}-I Q L_{i j}\right)-\left(S U_{i}-S L_{i}\right)^{t}+N V_{i}^{t}=0
\end{gathered}
$$

for all pond nodes $i$,

$$
\begin{gathered}
\sum_{j}\left(O Q N_{j i}^{t}+O Q U_{j i}^{t}-O Q L_{j i}^{t}\right)- \\
\sum_{j}\left(I Q N_{i j}^{t}+I Q U_{i j}^{t}-I Q L_{i j}^{t}\right)+I_{i}^{t}-\left(T R_{i}^{t}-D W_{i}^{t}\right)=0
\end{gathered}
$$

for all general nodes $i$,

$$
\begin{gathered}
\left(I Q N_{i j}^{t}+I Q v_{i j}^{t}-I Q L_{i j}^{t}\right)-\left(O Q N_{i j}^{t}+O Q v_{i j}^{t}-O Q L_{i j}^{t}\right)- \\
E V_{i}^{t}-S P_{i}^{t}=s_{i}^{t}-s_{i}^{t-1}
\end{gathered}
$$

for canal flow arcs $(i, j)$,

$$
\begin{gathered}
0 \leq S U_{i}^{t} \leq \overline{S U}_{i}, \\
0 \leq S L_{i}^{t} \leq \overline{S L}_{i}, \\
0 \leq \underline{Q N}_{i j} \leq Q N_{i j}^{t} \leq \overline{Q N}_{i j}, \\
0 \leq Q U_{i}^{t} \leq \overline{Q U}_{i}, \\
0 \leq Q L_{i}^{t} \leq \overline{Q L}_{i}, \\
0 \leq D W_{i}^{t} \leq T R_{i}^{t},
\end{gathered}
$$

where $C_{i}{ }^{u}$ and $C_{i}^{l}$ were the penalty coefficients for cost per unit; and the upper bars and lower bars in equations 32-37 were upper and lower flow boundaries of an associated arc. Water storage deviated from the rule curve at pond node $i$ for the upper zone and lower zone, respectively. $C_{i j}{ }^{n}, C_{i j}{ }^{\mu}$, and $C_{i j}{ }^{l}$ denoted the penalty coefficients for cost per unit flow in canal $i j$ for the normal, upper, and lower flow zones, respectively.

The linear-network optimization flow model given by equations $28-37$ was a typical minimum-cost flow problem in network analysis. Several algorithms exist for solving a minimum-cost flow problem. One of the algorithms, called the out-of-kilter algorithm (Fulkerson, 1961; Bazaraa and others, 1990), was used in developing the computer program called OPONDS (the optimal Operation of a system of PONDS) developed for this study (see Appendices for the description and listing of the computer program).

\section{Model Supplements}

In the following section, the methods used in OPONDS to estimate canal water storage, canal-flow transmission loss, surface runoff, and flow through hydraulic structures are described.

\section{Estimation of Canal Water Storage}

The Muskingum's method (McCuen, 1989) was used to estimate canal storage in this study. The method assumes that, for given a reach, canal storage $(S)$ can be expressed in terms of inflow and outflow rates as follows:

$$
S=K[x I+(1-x) O]
$$

where

$K=$ the storage constant defined by the ratio of storage to discharge. The storage constant $K$ has the dimension of time; therefore, $K$ is often called traveltime. The coefficients of $K$ and $x$ are generally determined using historical discharge data (Wu and others, 1985; Chow and others, 1988; McCuen, 1989);

$x=$ the dimensionless weighting factor for the storage effect of inflow and outflow. The value of $x$ is usually between 0 and 0.5 ;

$I=$ inflow rate; and

$O=$ outflow rate.

\section{Estimation of Canal-Flow Transmission Losses}

To estimate canal-flow transmission losses to an aquifer, two approximation methods were included in the computer program OPONDS. The first one was based on Darcy's equation given by:

$$
q=K_{b} \frac{\left(Z_{s w}-Z_{g w}\right)}{d} L B
$$


where

$q=$ canal seepage rate along canal reach;

$K_{b}=$ canal-bottom hydraulic conductivity;

$Z_{s w}=$ average canal surface-water elevation, which is the average water depth $(h)$ plus the canal-bottom elevation $\left(Z_{b}\right)$;

$Z_{g w}=$ average ground-water elevation below the canal bottom, which is the average value along the canal;

$d=$ average canal-bottom thickness;

$L=$ canal-reach length; and

$B=$ canal water-surface width.

If a canal gained water from the aquifer, the seepage ( $q$ ) in equation 39 was a negative number. If the ground-water elevation $Z_{g w}$ was lower than the average canal-bottom elevation, then the seepage rate, $q$, was simplified as:

$$
q=K_{b} h L B
$$

where $h$ was the average water depth in a canal reach.

The water depth $h$ was estimated iteratively using Manning's equation (Henderson, 1966):

$$
v=\frac{1.486 R^{2 / 3} J^{1 / 2}}{n},
$$

in which $v$ was the average velocity, in feet per second [ $v=Q / A(h)$ ]; $R$ was the hydraulic radius $[R=A(h) /$ $P(h)$ ], in feet; $A(h)$ was the cross-section area, in square feet; $P(h)$ was the wetted perimeter in feet; $J$ was the hydraulic slope; and $n$ was the roughness coefficient, which is dependent on canal bottom materials.

The second approximation method (Jordan, 1977) assumed that the rate of canal-flow transmission loss at any point was proportional to the flow at that point and that the canal characteristics were uniform for a given reach; that is,

$$
\frac{d Q_{x}}{d x}=-k Q_{x}
$$

where $\quad x$ was the distance coordinate, and $k$ was the transmission loss per unit length of canal $[1 / \mathrm{L}]$ and was simply called transmission loss coefficient.
For a given canal reach of length $L$, the transmission loss then was estimated by:

$$
q=\left(1.0-e^{-k L}\right) I Q=c I Q
$$

where $I Q$ was the inflow entering a canal, and $c$ was a transmission loss rate for a given canal reach of length $L$ and was estimated using seepage test data with a least-squares technique or other techniques.

\section{Estimation of Direct Overland Surface Runoff}

The Soil Conservation Service (1985) developed a method for estimating direct overland surface runoff depth from precipitation. The runoff depth $Q$ generated by precipitation $P$ was given by:

$$
Q=\frac{(P-0.2 S)^{2}}{P+0.8 S}
$$

where $S$ was the potential maximum retention (the amount of rain not converted to runoff after runoff begins) given by:

$$
S=\frac{1000}{C N}-10,
$$

in which $C N$ was the SCS curve number. The SCS curve number $(C N)$ is an index that represents the combination of hydrologic soil group and land use. $C N$ is a function of three factors-soil group, land-cover type, and antecedent moisture conditions. The range of $C N$ is from 0 to 100 . The curve number for average antecedent soil-moisture conditions (AMC II) can be interpreted for given soil properties and land-cover type (Soil Conservation Service, 1985; McCuen, 1989). For dry conditions (AMC I) and wet conditions (AMC III), equivalent curve numbers can be computed using the following equations (Chow and others, 1988):

$$
C N(I)=\frac{4.2 C N(I I)}{10-0.058 C N(I I)},
$$

and

$$
C N(I I I)=\frac{23 C N(I I)}{10+0.13 C N(I I)},
$$


where $C N(I), C N(I I)$, and $C N(I I I)$ are the curve numbers for the dry, average, and wet conditions, respectively.

The range of antecedent moisture conditions for each class is shown in table 5 (Chow and others, 1988). The SCS curve numbers for average soil-moisture conditions for the Quivira National Wildlife Refuge are summarized in table 4 in an earlier section.

\section{Flow Through Hydraulic Structures}

Water releases from ponds are through hydraulic control structures. The amount of water release depends on several factors, such as the pond water level, hydraulic-structure types and sizes, and the operation of structures. In the following sections, flows through four types of structures are discussed.

\section{Flow Over Sharp-Crested Weir}

A sharp-crested weir consists of a vertical plate mounted at right angles to the flow and having a sharp-edged crest (fig. 10A). The discharge equation is:

$$
Q=m b \sqrt{2 g} H_{o}^{1.5}
$$

where

$$
\begin{aligned}
Q= & \text { discharge over weir, in cubic feet per } \\
& \text { second; } \\
m= & \text { discharge coefficient, which is } \\
& \text { dimensionless; } \\
b= & \text { weir length, in feet; } \\
H_{o}= & \text { total energy head }\left(=H+v_{o}^{2} / 2 g\right) \text {, in feet. If } \\
& \text { approaching velocity } v_{o} \approx 0, \text { then } H_{o}=H, \\
& \text { where } H \text { is the static water head on a weir, } \\
& \text { referred to as the weir crest; and } \\
g= & \text { gravity acceleration }\left(=32.17 \mathrm{ft} / \mathrm{s}^{2}\right) .
\end{aligned}
$$

The discharge coefficient $(m)$ for free discharge is a function of certain dimensionless ratios that describe the geometry of the canal and the weir (Hulsing, 1967). One simple expression for free discharge with no side contraction is (Henderson, 1966):

$$
m=0.4073+0.0533(H / P), \text { where } 0<H / P<5,
$$

in which $P$ is the weir height (fig. 10A).

\section{Flow Under Gate on Broad-Crested Weir}

Flow under a vertical sluice gate on a broad-crested weir (fig. 10B) was calculated by:
Table 5. Classification of antecedent soil-moisture conditions (AMC) for SCS curve-number method of rainfall abstractions

[From Chow and others, 1988]

\begin{tabular}{ccc}
\hline & \multicolumn{2}{c}{ Total 5-day antecedent rainfall (inches) } \\
\cline { 2 - 3 } AMC & Dormant season & Growing season \\
\hline I & Less than 0.5 & Less than 1.4 \\
II & $0.5-1.1$ & $1.4-3.1$ \\
III & More than 1.1 & More than 3.1 \\
\hline
\end{tabular}

$$
Q=m b e \sqrt{2 g H_{o}}
$$

where $e$ was the gate opening height, and the other terms had the same definitions as in equation 48 .

If $e / H>0.65$, flow was not affected by the gate. The discharge coefficient for the free outflow under the gate depended on the relative gate opening height $(e / H)$ and was approximated by (Swamee, 1992):

$$
m=0.611\left(\frac{1-\frac{e}{H}}{1+15 \frac{e}{H}}\right)^{0.072},
$$

where $e / H<0.65$.

\section{Flow Under Gate on Spillway}

Flow under a gate on a spillway was calculated by:

$$
Q=m b e \sqrt{2 g H_{o}} .
$$

The definition of variables in equation 52 is the same as equation 50 . The discharge coefficient $(m)$ for a standard spillway depended not only on the relative gate opening height $(e / H)$ but also on the design water head $\left(H_{d}\right)$ and design discharge coefficient $\left(m_{d}\right)$ (U.S. Army Engineer Waterways Experiments Station, 1972). In the case that design water head and design coefficient were not available, the free outfall flow with a flat gate and sharp-crested edge of the gate facing downstream (fig. 10C) was approximated using the following equation (Chengdu Science and Technology University, 1979):

$$
m=0.65-0.186(e / H)
$$




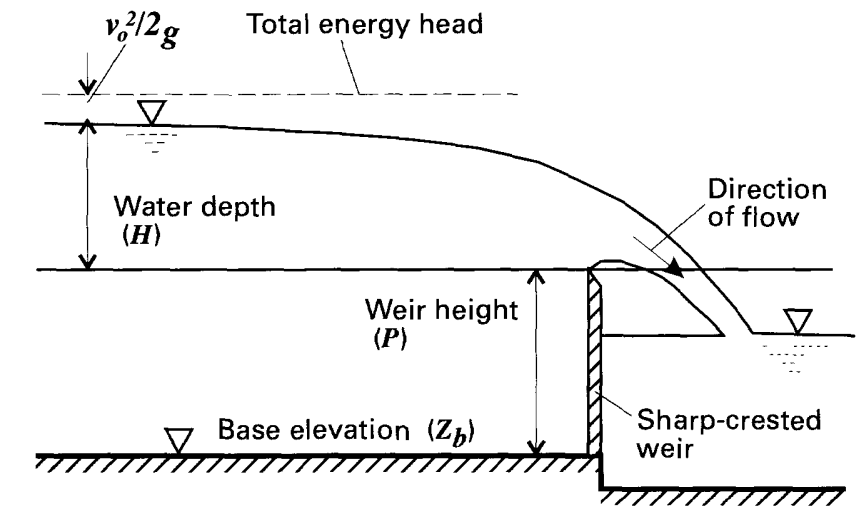

NOT TO SCALE

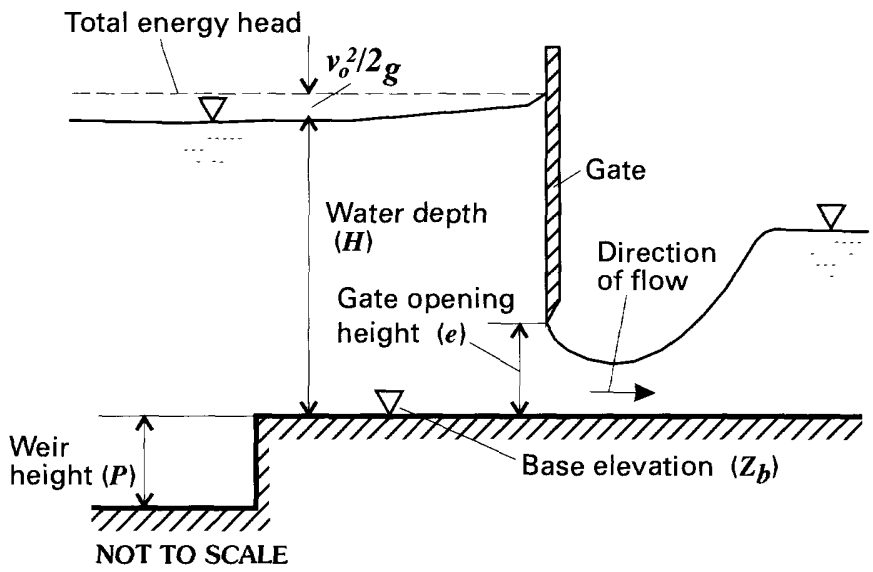

B. Gate on broad-crested weir.

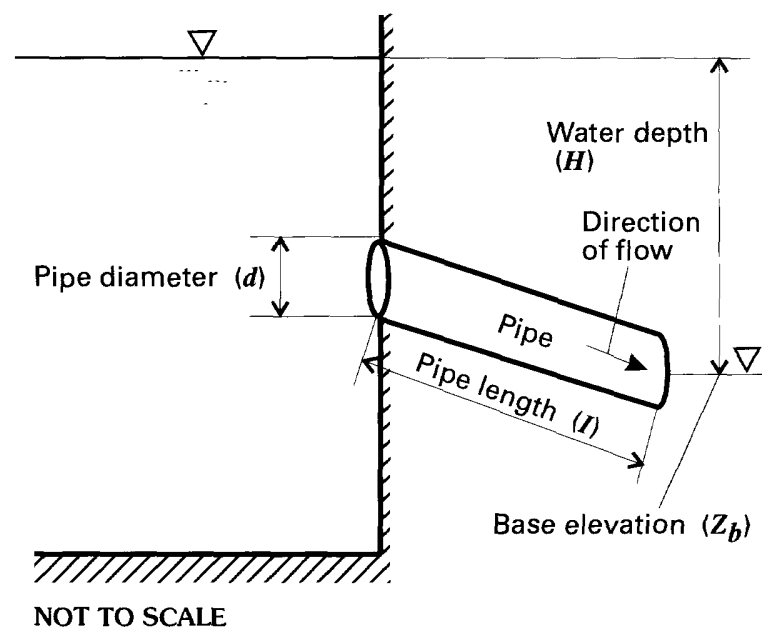

D. Pipe.

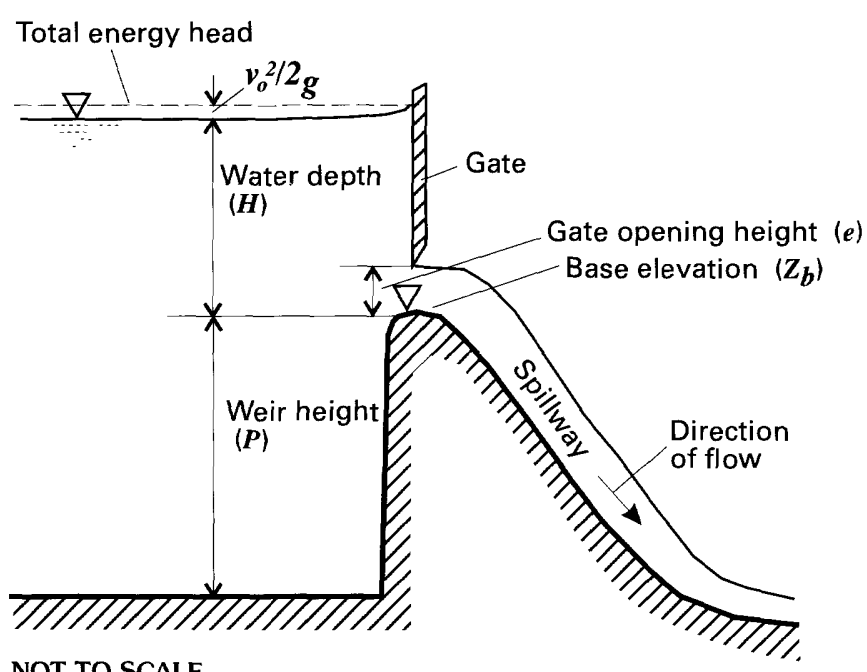

C. Gate on spillway. by (Chengdu Science and Technology University, 1979):

$$
m=\frac{1}{\sqrt{1+\lambda \frac{l}{d}+\Sigma \zeta}}
$$

where $\quad l$ was the length of the pipe, $d$ was the diameter of the pipe, $\lambda$ was the pipe friction coefficient that was determined by pipe 
materials, and $\zeta$ was the entrance loss coefficient that was determined by the shape of the entrance.

\section{SIMULATION OF CANAL AND CONTROL- POND OPERATION FOR 1996}

From June 11 through December 11, 1996, personnel at the Quivira National Wildlife Refuge measured water-surface levels about four or five times a month for most ponds. Streamflow discharges at the Rattlesnake Creek near Zenith and Raymond streamflow-gaging stations were measured continuously by USGS; however, the discharges in canals on the refuge were not measured. A simulation was conducted to determine the operation of canals and control ponds under 1996 conditions. The major objective was to determine the operation policy for canals and control ponds on the refuge so that the simulated pond water levels would match well with the measured water levels. The basic approach was to use the measured pond water levels as the pond rule curve, to set up pond zoning and the priority relations of control ponds, to determine pond releases to canals or other ponds to satisfy the measured discharges of Rattlesnake Creek near Raymond, and to examine simulated water levels for those ponds without water-level measurements. In the following sections, the data and the related necessary assumptions needed to conduct the simulation are discussed, the operation policy of ponds is discussed, and the simulation results are presented.

\section{Data Preparation}

In this section, data needed for the simulation are discussed. Measurement data were used if available. If some data were not available, reasonable values were estimated from other sources.

\section{Precipitation}

The amount of precipitation directly affects the surface runoff to ponds. Daily precipitation measured at the refuge headquarters from June 11 through December 11, 1996, is shown in figure 11A (Marios Sophocleous, Kansas Geological Survey, written commun., 1997). The total amount of precipitation for the period was 13.96 in.

\section{Water-Surface Evaporation}

The daily potential evapotranspiration (PET) (Marios Sophocleous, Kansas Geological Survey, written commun., 1997) is shown in figure $11 B$. It was assumed that the daily water-surface evaporation rates on the refuge were the same as the corresponding daily potential evapotranspiration. The total water-surface evaporation for the simulation period was 25.21 in.

\section{Canal Discharge}

Discharge for Rattlesnake Creek measured at the USGS streamflow-gaging stations near Zenith and Raymond from June 11 through December 11, 1996, is shown in figure $11 C$. The mean daily discharge rates for the simulation period were 48.72 and $47.73 \mathrm{ft}^{3} / \mathrm{s}$ for the Zenith and Raymond stations, respectively.

For this simulation, the daily mean discharges observed at the USGS Zenith station were used as water supply from Rattlesnake Creek to Little Salt Marsh. The daily mean discharges observed at the USGS Raymond station were used as the required stream outflow from the refuge through Rattlesnake Creek.

\section{Canal-Flow Transmission Losses}

Flow transmission losses from canals on the refuge were difficult to estimate. Personnel from the refuge did four seepage tests (table 6) along a 15,129-ft reach of Rattlesnake Creek downstream from Little Salt Marsh during 1996 (see fig. 2). Applying the least-squares method to equation 43 , the estimated transmission loss coefficient $(k)$ (equation 42 ) was equal to $9.16 \times 10^{-6} \mathrm{ft}^{-1}$. Due to a lack of data for the remaining canals on the refuge, this value of $k$ was used for the estimation of flow transmission loss rate $c$ (equation 43) for all canals south of the RC Canal. Because canals north of the RC Canal are located in the ground-water discharge area, no canal-flow transmission losses occurred for these canals. The ground-water discharge to these canals was included in discharge to ponds (see table 2).

\section{Ground-Water Discharge to Ponds}

Ground-water discharge to ponds on the refuge during the simulation period was not available. Instead, ground-water discharges to ponds based on information provided by Marios Sophocleous (Kansas 

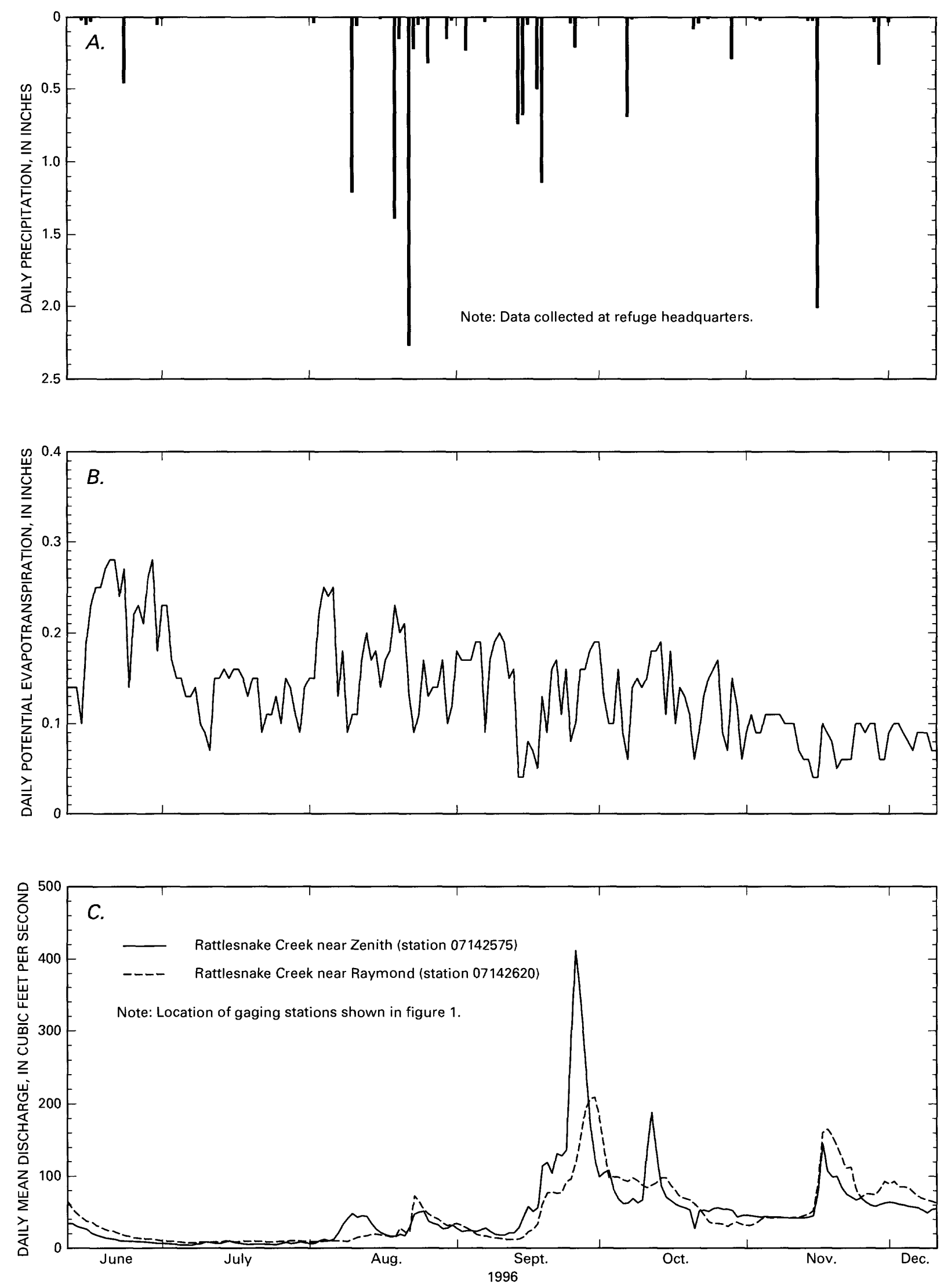

Figure 11. (A) Daily precipitation, (B) daily potential evapotranspiration, $(C)$ daily mean discharge for Rattlesnake Creek, June 11 through December 11, 1996. Precipitation and potential evapotranspiration data from the Kansas Geological Survey (Marios Sophocleous, written commun., 1997). 
Table 6. Results of seepage tests along Rattlesnake Creek, 1996, at Quivira National Wildlife Refuge

[Data from U.S. Fish and Wildlife Service (Megan Estep-Johnston, written commun., 1996). $\mathrm{ft}^{3} / \mathrm{s}$, cubic feet per second]

\begin{tabular}{ccc}
\hline \multirow{2}{*}{$\begin{array}{c}\text { Date } \\
\text { (month/day/ } \\
\text { year) }\end{array}$} & $\begin{array}{c}\text { Dpstream test } \\
\text { site 1 } \\
\text { (fig. 2) }\end{array}$ & $\begin{array}{c}\text { Downstream } \\
\text { test site 2 } \\
\text { (fig. 2) }\end{array}$ \\
\hline $06 / 26 / 96$ & 6.93 & 6.15 \\
$07 / 17 / 96$ & 8.98 & 7.46 \\
$07 / 24 / 96$ & 3.13 & 2.92 \\
$09 / 09 / 96$ & 5.52 & 5.12 \\
\hline
\end{tabular}

Geological Survey, written commun., 1997) for 1994 were used (table 2).

\section{Pond Water-Surface Elevations}

Water-surface elevations for selected control ponds were measured during the simulation period. Table 7 lists the ponds with measured water-surface elevations, the number of measurements, and the minimum and maximum water-surface elevations for the ponds. Because the water levels may be at the bottom of ponds or above the staff gage at ponds, the number of observations of water-surface elevations listed in table 7 may be different than the number of measurements listed. The difference between the number of observations and the number of measured elevations is the number of records without measurements. Those water-surface elevations observed outside the range of measurement on pond staff gages were treated accordingly as the pond-bottom elevation or the full-pond elevation in this simulation.

\section{Pond Zoning and Operating Policy}

Each control pond was divided into four storage zones-inactive zone, lower zone, upper zone, and extended upper zone as shown in figure 5. Target water levels (rule curves) were set at the top of the lower zone. For ponds with measured water-surface elevations (table 7), the measured water elevations were used as their rule curves, which indicates that the rule curves changed during the simulation period and so did the storage capacity of lower and upper zones. For those ponds without measured water levels, the rule curves were set at 95 percent of their corresponding full-pond storage capacities. The capacity of the inactive zone of a pond was set at 20 percent of full-pond storage capacity (selected in consultation with the U.S. Fish and Wildlife Service). Some of the rule curves for some ponds with measured water levels were located in the inactive zone during the simulation. In this case, the top boundary of the inactive zone capacity was set at the rule curve, and the capacity of the lower zone was set to zero. The top boundary of the upper zone was set at the full-pond elevation. The top boundary of the extended upper zone was set $0.5 \mathrm{ft}$ higher than its full-pond elevation. For ponds whose maximum measured water levels were higher than the full-pond elevation plus $0.5 \mathrm{ft}$, the top boundaries of the extended upper zone were set at the maximum measured water level. Pond zoning expressed as pond storage is summarized in table 8 .

To operate the system of canals and control ponds on the refuge, it was necessary to establish the priority of the ponds. Because Little Salt Marsh (water unit 5), which is supplied by Rattlesnake Creek, serves as the principal water-storage unit for the entire refuge, the highest operational priorities were given to its storages zones. Water units $(75,78,80,81$, and 83 , see fig. 2$)$ in the north part of the refuge were given the lowest operational priorities because these ponds are at the downstream end of the refuge and control less drainage area. The remaining ponds were given priorities in between the highest and the lowest priorities. Under this operating policy, water to satisfy the downstream water requirements was released first (1) from the lowest priority ponds when water levels at the highest priority ponds were below the rule curve so that high-priority pond water levels were as close as possible to their rule curves, or (2) from the highest priority ponds when their water levels were higher than the rule curves so that the water levels would decrease to as close to their rule curves as possible. To represent priorities of ponds, different penalty coefficients were assigned to each of the storage zones of the ponds. The higher the priority, the higher the penalty coefficient assigned. It should be noted that the relative magnitudes, not the absolute values, of the penalty coefficients determined the optimal operation of the system. Different combinations of assigned values of penalty coefficients were tested for the control ponds on the refuge. Typical values of penalty coefficients used in this simulation are summarized in table 8.

Because there are no flow requirements such as minimum-required flow for canals on the refuge, there 
Table 7. Summary of water-surface elevations for selected ponds at Quivira National Wildlife Refuge, June 11 through December 11, 1996

[Data from U.S. Fish Wildlife Service, written commun., 1997]

\begin{tabular}{|c|c|c|c|c|}
\hline $\begin{array}{l}\text { Water-unit } \\
\text { number } \\
\text { (fig. 2) }\end{array}$ & $\begin{array}{c}\text { Number of } \\
\text { observations }\end{array}$ & $\begin{array}{c}\text { Number of } \\
\text { measurements }\end{array}$ & $\begin{array}{c}\text { Maximum } \\
\text { measured } \\
\text { elevation (feet } \\
\text { above sea level) }\end{array}$ & $\begin{array}{c}\text { Minimum } \\
\text { measured } \\
\text { elevation (feet } \\
\text { above sea level) }\end{array}$ \\
\hline 5 & 30 & 30 & $1,783.30$ & $1,782.62$ \\
\hline 7 & 30 & 23 & $1,778.96$ & $1,777.33$ \\
\hline $10 \mathrm{~A}$ & 30 & 16 & $1,778.67$ & $1,777.03$ \\
\hline 10B & 30 & 29 & $1,778.89$ & $1,777.32$ \\
\hline $10 \mathrm{C}$ & 32 & 32 & $1,774.86$ & $1,773.22$ \\
\hline 11 & 32 & 14 & $1,773.91$ & $1,771.95$ \\
\hline $14 \mathrm{~A}$ & 30 & 30 & $1,777.92$ & $1,776.30$ \\
\hline $14 B$ & 30 & 30 & $1,777.36$ & $1,774.90$ \\
\hline 16 & 30 & 28 & $1,774.46$ & $1,772.72$ \\
\hline $20 \mathrm{~A}$ & 29 & 29 & $1,770.84$ & $1,769.56$ \\
\hline 21 & 29 & 17 & $1,769.09$ & $1,767.00$ \\
\hline 22 & 29 & 29 & $1,767.17$ & $1,764.91$ \\
\hline 23 & 29 & 27 & $1,764.78$ & $1,763.02$ \\
\hline 24 & 30 & 30 & $1,770.46$ & $1,769.61$ \\
\hline 25 & 33 & 20 & $1,766.92$ & $1,763.16$ \\
\hline 26 & 28 & 28 & $1,762.06$ & $1,760.14$ \\
\hline 28 & 30 & 17 & $1,767.81$ & $1,764.10$ \\
\hline 29 & 30 & 26 & $1,761.83$ & $1,757.20$ \\
\hline 30 & 30 & 17 & $1,760.01$ & $1,756.48$ \\
\hline 40 & 29 & 22 & $1,742.59$ & $1,738.58$ \\
\hline 48 & 29 & 25 & $1,754.28$ & $1,750.88$ \\
\hline 49 & 29 & 29 & $1,754.13$ & $1,750.25$ \\
\hline 58 & 30 & 30 & $1,740.90$ & $1,739.59$ \\
\hline 61 & 29 & 29 & $1,743.89$ & $1,742.54$ \\
\hline 62 & 29 & 29 & $1,742.64$ & $1,739.55$ \\
\hline 63 & 29 & 29 & $1,740.73$ & $1,739.17$ \\
\hline 75 & 29 & 7 & $1,740.17$ & $1,739.55$ \\
\hline
\end{tabular}


Table 8. Initial storage, zoning, and penalty coefficients assigned to control ponds at Quivira National Wildlife Refuge, June 11 through December 11, 1996

\begin{tabular}{|c|c|c|c|c|c|c|c|c|c|}
\hline $\begin{array}{l}\text { Water-unit } \\
\text { number } \\
\text { (fig. 2) }\end{array}$ & $\begin{array}{c}\text { initiai } \\
\text { storage } \\
\text { (acre-feet) }\end{array}$ & $\begin{array}{c}\text { Upper } \\
\text { boundary } \\
\text { of } \\
\text { extended } \\
\text { upper } \\
\text { zone } \\
\text { (acre-feet) }\end{array}$ & $\begin{array}{l}\text { Penaity } \\
\text { coefficient } \\
\text { for } \\
\text { extended } \\
\text { upper } \\
\text { zone }\end{array}$ & $\begin{array}{c}\text { Upper } \\
\text { boundary } \\
\text { of upper } \\
\text { zone } \\
\text { (acre-feet) }\end{array}$ & $\begin{array}{c}\text { Penalty } \\
\text { coefficient } \\
\text { for upper } \\
\text { zone }\end{array}$ & $\begin{array}{l}\text { Lower } \\
\text { boundary } \\
\text { of iower } \\
\text { zone } \\
\text { (acre-feet) }\end{array}$ & $\begin{array}{l}\text { Penaity } \\
\text { coefficient } \\
\text { for iower } \\
\text { zone }\end{array}$ & $\begin{array}{c}\text { Lower } \\
\text { boundary } \\
\text { of } \\
\text { inactive } \\
\text { zone } \\
\text { (acre-feet) }\end{array}$ & $\begin{array}{c}\text { Penaity } \\
\text { coefficient } \\
\text { for } \\
\text { inactive } \\
\text { zone }\end{array}$ \\
\hline 5 & $1,988.26$ & $2,312.18$ & 2,000 & $1,866.00$ & 1,500 & 373.20 & 1,500 & 1.00 & 5,000 \\
\hline 7 & 39.72 & 72.90 & 2,000 & 40.00 & 1,500 & 8.00 & 1,000 & 1.00 & 2,000 \\
\hline $10 \mathrm{~A}$ & 145.48 & 180.30 & 2,000 & 145.00 & 1,500 & 29.00 & 1,000 & 1.00 & 2,000 \\
\hline $10 \mathrm{~B}$ & 145.48 & 180.30 & 2,000 & 145.00 & 1,500 & 29.00 & 1,000 & 1.00 & 2,000 \\
\hline $10 \mathrm{C}$ & 19.54 & 21.81 & 2,000 & 13.00 & 1,500 & 2.60 & 1,000 & 1.00 & 2,000 \\
\hline 11 & 388.37 & 440.07 & 2,000 & 338.00 & 1,500 & 67.60 & 1,000 & 1.00 & 2,000 \\
\hline $14 \mathrm{~A}$ & 161.70 & 242.20 & 2,000 & 196.00 & 1,500 & 39.20 & 1,000 & 1.00 & 2,000 \\
\hline $14 \mathrm{~B}$ & 93.40 & 185.74 & 2,000 & 96.00 & 1,500 & 19.20 & 1,000 & 1.00 & 2,000 \\
\hline $14 \mathrm{C}$ & 15.51 & 19.07 & 2,000 & 16.00 & 500 & 3.20 & 500 & 1.00 & 2,000 \\
\hline 16 & 62.67 & 96.07 & 2,000 & 80.00 & 1,500 & 16.00 & 1,000 & 1.00 & 2,000 \\
\hline $20 \mathrm{~A}$ & 163.88 & 268.01 & 2,000 & 195.00 & 1,500 & 39.00 & 1,000 & 1.00 & 2,000 \\
\hline $20 \mathrm{~B}$ & 163.88 & 268.01 & 2,000 & 195.00 & 1,500 & 39.00 & 1,000 & 1.00 & 2,000 \\
\hline 21 & 34.34 & 96.62 & 2,000 & 81.00 & 1,500 & 16.20 & 1,000 & 1.00 & 2,000 \\
\hline 22 & 2.30 & 18.81 & 2,000 & 13.00 & 1,500 & 2.60 & 1,000 & 1.00 & 2,000 \\
\hline 23 & 15.41 & 19.66 & 2,000 & 15.00 & 1,500 & 3.00 & 1,000 & 1.00 & 2,000 \\
\hline 24 & 132.55 & 139.01 & 2,000 & 35.00 & 1,500 & 7.00 & 1,000 & 1.00 & 2,000 \\
\hline 25 & 18.00 & 344.05 & 2,000 & 296.00 & 1,500 & 59.20 & 1,000 & 1.00 & 2,000 \\
\hline 26 & 91.48 & 142.39 & 2,000 & 111.00 & 1,500 & 22.20 & 1,000 & 1.00 & 2,000 \\
\hline 28 & 6.11 & 198.82 & 2,000 & 153.00 & 1,500 & 30.60 & 1,000 & 1.00 & 2,000 \\
\hline 29 & 0.20 & 124.51 & 2,000 & 91.00 & 1,500 & 18.20 & 1,000 & 1.00 & 2,000 \\
\hline 30 & 2.82 & 161.64 & 2,000 & 119.00 & 1,500 & 23.80 & 1,000 & 1.00 & 2,000 \\
\hline 40 & 55.91 & 83.19 & 2,000 & 66.00 & 1,500 & 13.20 & 1,000 & 1.00 & 2,000 \\
\hline 48 & 3.94 & 161.19 & 2,000 & 113.00 & 1,500 & 22.60 & 1,000 & 1.00 & 2,000 \\
\hline 49 & 51.63 & 209.05 & 2,000 & 159.00 & 1,500 & 31.80 & 1,000 & 1.00 & 2,000 \\
\hline 57 & 212.22 & 280.74 & 2,000 & 212.00 & 1,500 & 42.40 & 1,000 & 1.00 & 2,000 \\
\hline
\end{tabular}


Table 8. Initial storage, zoning, and penalty coefficients assigned to control ponds at Quivira National Wildlife Refuge, June 11 through December 11, 1996-Continued

\begin{tabular}{|c|c|c|c|c|c|c|c|c|c|}
\hline $\begin{array}{l}\text { Water-unit } \\
\text { number } \\
\text { (fig. 2) }\end{array}$ & $\begin{array}{c}\text { Initial } \\
\text { storage } \\
\text { (acre-feet) }\end{array}$ & $\begin{array}{c}\text { Upper } \\
\text { boundary } \\
\text { of } \\
\text { extended } \\
\text { upper } \\
\text { zone } \\
\text { (acre-feet) }\end{array}$ & $\begin{array}{c}\text { Penalty } \\
\text { coefficient } \\
\text { for } \\
\text { extended } \\
\text { upper } \\
\text { zone }\end{array}$ & $\begin{array}{c}\text { Upper } \\
\text { boundary } \\
\text { of upper } \\
\text { zone } \\
\text { (acre-feet) }\end{array}$ & $\begin{array}{c}\text { Penalty } \\
\text { coefficient } \\
\text { for upper } \\
\text { zone }\end{array}$ & $\begin{array}{c}\text { Lower } \\
\text { boundary } \\
\text { of lower } \\
\text { zone } \\
\text { (acre-feet) }\end{array}$ & $\begin{array}{l}\text { Penalty } \\
\text { coefficient } \\
\text { for lower } \\
\text { zone }\end{array}$ & $\begin{array}{c}\text { Lower } \\
\text { boundary } \\
\text { of } \\
\text { inactive } \\
\text { zone } \\
\text { (acre-feet) }\end{array}$ & $\begin{array}{l}\text { Penalty } \\
\text { coefficient } \\
\text { for } \\
\text { inactive } \\
\text { zone }\end{array}$ \\
\hline 58 & 146.39 & 302.82 & 2,000 & 251.00 & 1,500 & 50.20 & 1,000 & 1.00 & 2,000 \\
\hline 61 & 212.80 & 613.17 & 2,000 & 498.00 & 1,500 & 99.60 & 1,000 & 1.00 & 2,000 \\
\hline 62 & 48.58 & 145.00 & 2,000 & 120.00 & 1,500 & 24.00 & 1,000 & 1.00 & 2,000 \\
\hline 63 & 268.98 & 419.01 & 2,000 & 339.00 & 1,500 & 67.80 & 1,000 & 1.00 & 2,000 \\
\hline 75 & $2,445.85$ & $3,490.32$ & 1,000 & $2,446.00$ & 500 & 489.20 & 500 & 1.00 & 2,000 \\
\hline 78 & $5,270.43$ & $6,091.37$ & 1,000 & $5,270.00$ & 500 & $1,054.00$ & 500 & 1.00 & 2,000 \\
\hline 80 & 355.20 & 474.34 & 1,000 & 355.00 & 500 & 71.00 & 500 & 1.00 & 2,000 \\
\hline 81 & 25.31 & 60.68 & 1,000 & 25.00 & 500 & 5.00 & 500 & 1.00 & 2,000 \\
\hline 83 & 314.34 & 419.31 & 1,000 & 314.00 & 750 & 62.80 & 750 & 1.00 & 2,000 \\
\hline
\end{tabular}

was only one flow zone for canals designated in this simulation. It was assumed that flow through a canal reach ranged in magnitude from zero to the full capacity of the canal. Because of the complexity of the canal flow network on the refuge, flows could reach the same location through different routes of canals. Different penalty coefficients were assigned to the flow zones of canals so that the most efficient route could be determined by minimizing the total penalty applied to canal flows. However, costs of transporting water through canals were not available. Because Rattlesnake Creek is used as the major route to distribute water to the refuge and because other canals are used only when necessary, flows through Rattlesnake Creek and canals downstream from control ponds were assigned penalty coefficients of zero, and the remaining canals were assigned nonzero penalty coefficients as shown in table 9 (see figures 2 and 4 for nodal names, location, and flow network).

\section{Results}

The simulation of canal and control-pond operation at the Quivira National Wildlife Refuge for June 11 through December 11, 1996, was conducted using the following specifications for pond zoning, operating policy, and canal outflow from the refuge: (1) four storage zones for each pond, with the inactive storage of 20 percent of full-pond storage capacity; (2) rule curves set at the measured water levels for ponds with measurements, otherwise at 95 percent of full-pond storage capacity; (3) initial storage in ponds interpreted from the water levels measured on June 10, 1996, for ponds with measurements, otherwise set at 95 percent of full-pond storage capacity; and (4) outflows from the refuge through Rattlesnake Creek near the USGS streamflow-gaging station near Raymond equal to the observed discharges at the streamflow-gaging station (fig. 11C).

Figures $12 A-D$ show the water-budget components simulated for the operation of water unit 5. Similar figures also can be generated for other control ponds. Inflows shown in figure $12 A$ are upstream inflows from Rattlesnake Creek, which are equal to the discharges observed at the USGS streamflow-gaging station near Zenith. Total downstream releases shown in figure $12 C$ are the summations of releases to all downstream nodes (water units 7 and 10A, and nodes $\mathrm{C}-2$ and JE-1, see figure 4). Ground-water seepage during the simulation period shown in figure $12 B$ is almost the same for the whole simulation period (the values were estimated for 1994 , see table 2). Figure $12 E$ shows the simulated and measured water stages and depths. From July 9 to August 8, even though there were no releases from the pond, the simulated water stages were lower than the 
Table 9. Penalty coefficients for canal flows at Quivira National Wildlife Refuge, June 11 through December 11, 1996

\begin{tabular}{|c|c|c|c|c|c|c|c|c|}
\hline \multicolumn{2}{|c|}{ Canal } & \multirow[b]{2}{*}{$\begin{array}{c}\text { Penalty } \\
\text { coefficient }\end{array}$} & \multicolumn{2}{|c|}{ Canal } & \multirow[b]{2}{*}{$\begin{array}{c}\text { Penalty } \\
\text { coefficient }\end{array}$} & \multicolumn{2}{|c|}{ Canal } & \multirow[b]{2}{*}{$\begin{array}{c}\text { Penalty } \\
\text { coefficient }\end{array}$} \\
\hline $\begin{array}{c}\text { From-node } \\
\text { name } \\
\text { (fig. 4) }\end{array}$ & $\begin{array}{l}\text { To-node } \\
\text { name } \\
\text { (fig. 4) }\end{array}$ & & $\begin{array}{c}\text { From-node } \\
\text { name } \\
\text { (fig. 4) }\end{array}$ & $\begin{array}{l}\text { To-node } \\
\text { name } \\
\text { (fig. 4) }\end{array}$ & & $\begin{array}{c}\text { From-node } \\
\text { name } \\
\text { (fig. 4) }\end{array}$ & $\begin{array}{l}\text { To-node } \\
\text { name } \\
\text { (fig. 4) }\end{array}$ & \\
\hline Zenith & Unit 5 & 0 & Unit 24 & Unit 21 & 10 & Unit 61 & JE-4 & 0 \\
\hline Unit 5 & Unit 7 & 10 & Unit 24 & Unit 20B & 1,000 & Unit 63 & $\mathrm{JE}-5$ & 0 \\
\hline Unit 5 & Unit 10A & 10 & Unit 25 & JE-2 & 10 & Unit 63 & $\mathrm{JE}-6$ & 0 \\
\hline Unit 5 & $\mathrm{JE}-1$ & 0 & Unit 25 & Unit 26 & 10 & Unit 75 & Unit 78 & 10 \\
\hline Unit 5 & $C-2$ & 10 & Unit 26 & $48 \mathrm{E}$ & 10 & Unit 78 & Unit 81 & 10 \\
\hline Unit 7 & Unit 10B & 10 & $48 \mathrm{E}$ & Unit 48 & 0 & Unit 81 & Unit 80 & 10 \\
\hline Unit 10A & Unit 10B & 10 & $48 \mathrm{E}$ & Unit 49 & 0 & Unit 80 & $\mathrm{JN}-1$ & 0 \\
\hline Unit 10B & Unit 10C & 10 & Unit 28 & Unit 29 & 10 & Unit 83 & JN-1 & 0 \\
\hline Unit 10C & Unit 11 & 10 & Unit 29 & Unit 30 & 10 & $\mathrm{JN}-1$ & JE-7 & 0 \\
\hline Unit 11 & SKSC $^{1}$ & 1,250 & Unit 30 & WCE & 10 & $\mathrm{DCC}$ & DCF & 100 \\
\hline $\mathrm{C}-2$ & F-1 & 0 & WCE & Unit 48 & 0 & $\mathrm{DCC}$ & SKSC $^{1}$ & 5,000 \\
\hline $\mathrm{C}-2$ & D-1 & 0 & WCE & $\mathrm{RCD}$ & 0 & DCF & $40 \mathrm{C}$ & 100 \\
\hline F-1 & $\mathrm{F}-2$ & 0 & Unit 48 & Unit 49 & 10 & DCF & $\mathrm{JE}-0$ & 100 \\
\hline $\mathrm{F}-1$ & Unit 14B & 0 & Unit 48 & Unit 55 & 10 & $\mathrm{JE}-0$ & 37 & 100 \\
\hline D-1 & Unit $14 A$ & 0 & Unit 49 & $\mathrm{RCB}$ & 10 & 37 & 39 & 100 \\
\hline D-1 & WCA & 0 & Unit 49 & JE-3 & 10 & 39 & JE-9 & 100 \\
\hline Unit 14A & UNIT 16 & 10 & Unit 55 & $\mathrm{RCC}$ & 0 & $40 \mathrm{C}$ & Unit 40 & 0 \\
\hline Unit $14 \mathrm{~A}$ & $\mathrm{~J} 14$ & 10 & Unit 55 & $\mathrm{RCF}$ & 0 & $40 \mathrm{C}$ & Unit 62 & 0 \\
\hline Unit 14B & $\mathrm{J} 14$ & 10 & $\mathrm{JE}-1$ & Unit 24 & 0 & Unit 40 & JE-8 & 10 \\
\hline Unit 14B & Unit 20B & 10 & $\mathrm{JE}-2$ & $\mathrm{JE}-3$ & 0 & Unit 62 & $\mathrm{JE}-5$ & 10 \\
\hline $\mathrm{J} 14$ & Unit $20 \mathrm{~A}$ & 0 & JE-3 & $\mathrm{RCA}$ & 0 & Unit 62 & Unit 40 & 10 \\
\hline F-2 & Unit $14 C$ & 0 & RCA & RCB & 0 & JE-4 & JE-5 & 0 \\
\hline F-2 & Unit 20B & 0 & $\mathrm{RCA}$ & JE-4 & 0 & JE-5 & $\mathrm{JE}-6$ & 0 \\
\hline Unit $14 C$ & $\mathrm{JE}-1$ & 0 & RCB & Unit 61 & 0 & JE-6 & JE-7 & 0 \\
\hline Unit 16 & WCA & 10 & RCB & $\mathrm{RCC}$ & 0 & $\mathrm{JE}-7$ & JE-8 & 0 \\
\hline WCA & Unit 28 & 10 & $\mathrm{RCC}$ & $\mathrm{RCF}$ & 0 & JE-8 & JE-9 & 0 \\
\hline Unit 20A & Unit 21 & 10 & $\mathrm{RCF}$ & Unit 57 & 0 & JE-9 & JE-10 & 0 \\
\hline Unit 20B & Unit $20 \mathrm{~A}$ & 10 & $\mathrm{RCF}$ & $\mathrm{RCD}$ & 0 & $\mathrm{JE}-10$ & RAYMOND & 0 \\
\hline Unit 21 & Unit 22 & 10 & $\mathrm{RCD}$ & Unit 58 & 0 & RAYMOND & SKSC $^{1}$ & 0 \\
\hline Unit 22 & Unit 23 & 10 & Unit 57 & Unit 78 & 10 & & & \\
\hline Unit 23 & Unit 26 & 10 & Unit 58 & Unit 75 & 10 & & & \\
\hline Unit 24 & Unit 25 & 10 & Unit 58 & Unit 78 & 10 & & & \\
\hline Unit 24 & $\mathrm{JE}-2$ & 0 & Unit 61 & Unit 57 & 10 & & & \\
\hline Unit 24 & $\mathrm{DCC}$ & 100 & Unit 61 & Unit 63 & 10 & & & \\
\hline
\end{tabular}

${ }^{1}$ Nodal name SKSC is used to specify that the end node of a canal is outside the refuge. 

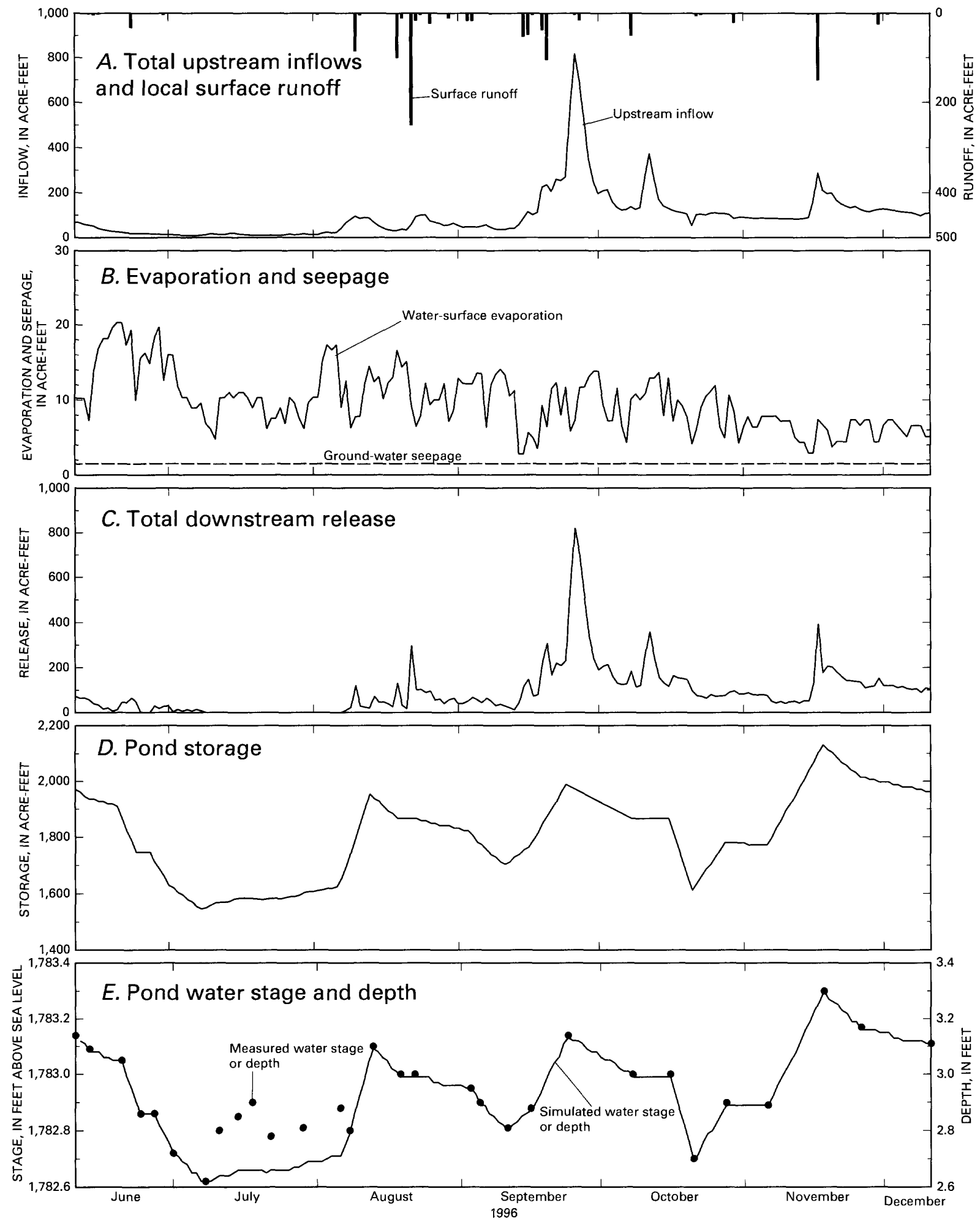

Figure 12. Water budget simulated for water unit 5, June 11 through December 11, 1996. 
measured ones. The differences in stages were about 0.1 to $0.2 \mathrm{ft}$. The cause of these differences might be errors in reading stage and in estimating water-surface evaporation. The simulated water levels matched well with measured ones for the simulation period. The root mean square error (RMSE) between the simulated $(\hat{Z})$ and measured $(Z)$ water levels was $0.08 \mathrm{ft}$ for water unit 5 (see equation $56 ; n$ is the number of comparisons):

$$
R M S E=\sqrt{\frac{\sum_{i=1}^{n}\left(\hat{Z}_{i}-z\right)^{2}}{n}} .
$$

Similar results were found for other ponds. The RMSEs for other ponds were less than $0.13 \mathrm{ft}$ except water units 24 and 30 for which RMSEs were 0.49 and $0.40 \mathrm{ft}$, respectively. In other words, the current specification for pond zoning and rule curves simulated the operation of ponds well.

Table 10 summarizes water-budget components of the ponds for the entire simulation period. For each pond, the water-balance equation was:

Initial water storage + upstream inflow + surface runoff - water-surface evaporation ground-water seepage - total downstream release $=$

$$
\text { final storage, }
$$

where upstream inflow was the total inflow to a pond from upstream canals; surface runoff was the total runoff calculated using the measured precipitation data and SCS curve numbers; water-surface evaporation was the total surface-water evaporation loss, which was estimated in terms of the water-surface area and potential evapotranspiration coefficients; groundwater seepage was the total water loss to an aquifer (positive values) or total water gain from an aquifer (negative values); downstream release was the total amount of water released to downstream canals from a pond; and final storage was the water stored in a pond at the end of the simulation period. It was shown that equation 57 was satisfied for all ponds.

Another way to examine the water budget is by viewing a whole flow system as a "system node," which combines canals and control ponds with inflow from the Zenith node and outflows from nodes Raymond, water unit 11, and DCC (see figure 4). The over- all water budget for the entire canal and control-pond system is summarized in table 11 for the entire simulation period. In table 11, initial storage was the summation of pond storage at the beginning of the simulation $(13,102.68$ acre-ft), which was interpreted from the measured water levels on June 10, 1996. Total stream inflow was the inflow from Kattlesnake Creek to water unit 5(17,782.21 acre-ft), which was measured at the USGS streamflow-gaging station near Zenith. Local water gain to the system included surface runoff due to precipitation (6,559.04 acre-ft, 6,499.77 acre- $\mathrm{ft}$ of which were to ponds) and ground-water seepage to ponds (3,035.56 acre-ft) and was equal to 9,594.60 acre-ft. The outflow was the summation of outflows released from node Raymond $(17,421.22$ acre-ft) and from node water unit 11 ( 400.85 acre-ft). Total stream inflow to the system was almost the same as the stream outflow from the system. Although the total inflow to the system (stream inflow, runoff, and ground-water seepage to ponds) was much larger than the stream outflow from the system, the final water storage in the system was significantly reduced from the initial storage of $13,102.68$ acre- $f t$ to $9,211.88$ acre-ft due to a large amount of local water loss through water-surface evaporation from ponds $(10,683.74$ acre- $\mathrm{ft})$ and canal-flow transmission losses $(2,761.79$ acre- $f t)$. The water loss due to water-surface evaporation was larger than the total local water gain within the refuge.

\section{SIMULATION OF CANAL AND CONTROL- POND OPERATION FOR 1991 WATER YEAR}

A simulation was conducted to determine the operation of the system of canals and control ponds under drought flow conditions as occurred during the 1991 water year (October 1, 1990, through September 30, 1991) with different rule curves. Discharge during the 1991 water year was used as simulated discharge because this water year was the driest in terms of total discharges in Rattlesnake Creek for water years 1973 through 1995 (Putnam and others, 1996). In the following sections, the data needed to conduct the simulation and the necessary assumptions about these data are discussed, and then the simulation results are presented. 
Table 10. Water budgets simulated for selected control ponds at Quivira National Wildlife Refuge, June 11 through December 11, 1996

[All values are in acre-feet; --, not applicable]

\begin{tabular}{|c|c|c|c|c|c|c|c|}
\hline $\begin{array}{l}\text { Water-unit } \\
\text { number } \\
\text { (fig. 2) }\end{array}$ & $\begin{array}{c}\text { initiai } \\
\text { storage }\end{array}$ & 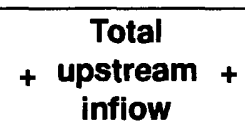 & $\begin{array}{c}\text { Totai } \\
+\quad \begin{array}{c}\text { surface } \\
\text { runoff }\end{array}\end{array}$ & $\begin{array}{c}\text { Water- } \\
\text { surface } \\
\text { evaporation }\end{array}$ & $\begin{array}{c}\text { Ground- } \\
\text { water } \\
\text { seepage }\end{array}$ & $\begin{array}{c}\text { Totai } \\
\text { downstream } \\
\text { reiease }\end{array}=$ & $\begin{array}{c}\text { Finai } \\
\text { storage }\end{array}$ \\
\hline 5 & $1,988.26$ & $17,782.22$ & $1,117.84$ & $1,795.73$ & 286.00 & $16,844.87$ & $1,961.72$ \\
\hline 7 & 39.72 & 486.93 & 31.98 & 57.25 & 0 & 431.67 & 69.71 \\
\hline $10 \mathrm{~A}$ & 145.48 & 169.66 & 57.79 & 109.78 & 0 & 117.67 & 145.48 \\
\hline $10 \mathrm{~B}$ & 145.48 & 531.21 & 55.60 & 98.40 & 34.04 & 467.15 & 132.70 \\
\hline $10 \mathrm{C}$ & 19.54 & 459.95 & 9.25 & 20.34 & 0 & 449.93 & 18.47 \\
\hline 11 & 388.37 & 448.42 & 54.08 & 101.65 & 0 & 400.85 & 388.37 \\
\hline $14 \mathrm{~A}$ & 161.70 & 214.52 & 96.82 & 152.05 & 0 & 152.25 & 168.74 \\
\hline $14 B$ & 93.40 & 197.43 & 150.80 & 120.57 & -9.20 & 179.99 & 150.27 \\
\hline $14 \mathrm{C}$ & 15.51 & 102.95 & 6.88 & 12.81 & 18.09 & 91.24 & 3.20 \\
\hline 16 & 62.67 & 114.02 & 29.02 & 51.88 & 0 & 92.57 & 61.26 \\
\hline $20 \mathrm{~A}$ & 163.88 & 493.65 & 142.78 & 250.73 & 0 & 353.34 & 196.24 \\
\hline $20 \mathrm{~B}$ & 163.88 & 433.68 & 141.17 & 249.69 & 7.36 & 285.45 & 196.23 \\
\hline 21 & 34.34 & 531.79 & 31.32 & 48.36 & 0 & 494.16 & 54.93 \\
\hline 22 & 2.30 & 489.96 & 13.63 & 22.24 & 0 & 460.62 & 23.03 \\
\hline 23 & 15.41 & 458.46 & 10.26 & 17.77 & 0 & 448.68 & 17.68 \\
\hline 24 & 132.55 & $12,741.83$ & 63.05 & 93.63 & 103.47 & $12,666.91$ & 73.42 \\
\hline 25 & 18.00 & 676.23 & 55.85 & 72.37 & 40.89 & 494.09 & 142.73 \\
\hline 26 & 91.48 & 862.43 & 63.69 & 93.92 & 7.25 & 829.71 & 86.72 \\
\hline 28 & 6.11 & 635.03 & 44.60 & 69.63 & 0 & 497.53 & 118.58 \\
\hline 29 & .20 & 482.72 & 38.38 & 53.35 & 0 & 404.38 & 63.57 \\
\hline 30 & 2.82 & 396.78 & 62.17 & 97.04 & 0 & 196.68 & 168.05 \\
\hline 40 & 55.91 & 77.90 & 14.03 & 34.19 & -36.27 & 83.58 & 66.34 \\
\hline 48 & 3.94 & 316.42 & 73.47 & 72.85 & 0 & 245.36 & 75.62 \\
\hline 49 & 51.63 & 567.52 & 64.72 & 102.76 & 11.87 & 437.18 & 132.06 \\
\hline 57 & 212.22 & $1,193.02$ & 156.57 & 257.91 & 0 & $1,102.51$ & 201.39 \\
\hline 58 & 146.39 & $1,388.52$ & 83.47 & 135.49 & -86.07 & $1,429.80$ & 139.16 \\
\hline 61 & 212.80 & 340.11 & 123.31 & 209.47 & -50.68 & 380.83 & 136.60 \\
\hline 62 & 48.58 & 59.57 & 17.64 & 33.97 & -31.89 & 57.62 & 66.09 \\
\hline 63 & 268.98 & 132.23 & 129.33 & 232.08 & -76.44 & 243.73 & 131.17 \\
\hline 75 & $2,445.85$ & $1,177.96$ & $1,445.34$ & $2,043.86$ & $-2,484.88$ & $4,004.79$ & $1,505.38$ \\
\hline 78 & $5,270.43$ & $5,359.15$ & $1,728.99$ & $3,161.14$ & -291.63 & $7,252.18$ & $2,236.88$ \\
\hline 80 & 355.20 & $7,542.65$ & 155.93 & 363.20 & -85.77 & $7,705.34$ & 71.01 \\
\hline 81 & 25.31 & $7,252.18$ & 41.67 & 94.73 & -323.22 & $7,542.65$ & 5.00 \\
\hline 83 & 314.34 & 0 & 188.34 & 352.91 & -68.48 & 14.14 & 204.11 \\
\hline Total & $13,102.68$ & -- & $6,499.77$ & $10,683.75$ & $-3,035.56$ & - & 9,211.91 \\
\hline
\end{tabular}


Table 11. Water budget simulated for entire canal and control-pond system at Quivira National Wildlife Refuge, June 11 through December 11, 1996

[All values are in acre-feet; --, not applicable]

\begin{tabular}{lccc}
\hline \multicolumn{1}{c}{$\begin{array}{c}\text { Water-budget } \\
\text { component }\end{array}$} & Storage & Inflow & Outflow \\
\hline Initial storage & $13,102.68$ & -- & -- \\
Stream inflow & -- & $17,782.21$ & -- \\
Surface runoff & -- & $6,559.04$ & -- \\
Water-surface & -- & -- & $10,683.74$ \\
evaporation & - & & \\
$\begin{array}{l}\text { Net ground-water } \\
\text { seepage }\end{array}$ & - & $3,035.56$ & -- \\
$\begin{array}{l}\text { Canal-flow } \\
\text { transmission loss }\end{array}$ & -- & -- & $2,761.79$ \\
$\begin{array}{l}\text { Outflow from } \\
\text { Raymond node }\end{array}$ & -- & -- & $17,822.07$ \\
Final storage & $\mathbf{9 , 2 1 1 . 8 8}$ & -- & -- \\
\hline
\end{tabular}

\section{Data Preparation}

In this section, data needed for the simulation are discussed. Measurement data were used if available. If some data were not available, reasonable values were interpreted on the basis of other related data.

\section{Precipitation}

One of the major factors affecting the generation of direct overland surface runoff to ponds is the amount of precipitation. Figure $13 A$ shows the daily precipitation measured at the Sandyland Experiment Station and at the USGS streamflow-gaging station near Zenith (fig. 1). Precipitation data from October 1, 1990, through May 20, 1991, were measured at the Sandyland Experiment Station. Precipitation data from May 21 through September 30, 1991, were measured at the USGS streamflow-gaging station near Zenith. The total amount of precipitation during the 1991 water year was 13.43 in.

\section{Water-Surface Evaporation}

The daily potential evapotranspiration (PET) estimated with the Penman method using the climatic data collected at the Sandyland Experiment Station (Marios Sophocleous, Kansas Geological Survey, written commun., 1996) is shown in figure $13 B$. The total amount of PET was 61.23 in. for the 1991 water year. For the
1991 water year simulation, it was assumed that the daily water-surface evaporation rate for ponds on the refuge was equal to the corresponding daily potential evapotranspiration at the Sandyland Experimental Station.

\section{Canal Discharge}

Discharges for Rattlesnake Creek measured at the USGS streamflow-gaging stations near Zenith and Raymond (fig. 1) from October 1, 1990, through September 30,1991, are shown in figure $13 C$ (Geiger and others, 1992). The mean daily discharges for the Zenith and Raymond stations during the 1991 water year were 6.59 and $2.77 \mathrm{ft}^{3} / \mathrm{s}$, respectively, which are much smaller than the long-term means of $50.6 \mathrm{ft}^{3} / \mathrm{s}$ (1973-95 water years) and $48.8 \mathrm{ft}^{3} / \mathrm{s}$ (1960-95 water years), respectively. As shown in the figure $13 C$, there was almost no flow during late September 1991.

For this simulation, the daily mean discharge observed at the USGS streamflow-gaging station near Zenith station was used as daily inflows to Little Salt Marsh from Rattlesnake Creek. The daily mean discharge observed at the USGS streamflow-gaging station near Raymond was used as the streamflow requirement for Rattlesnake Creek near Raymond.

\section{Canal-Flow Transmission Losses}

Canal-flow transmission loss was difficult to estimate. Because there were no data available to estimate the canal-flow transmission loss coefficient for the canals on the refuge during the simulation period, the estimated transmission loss coefficient ( $k$ in equation 42) of $9.16 \times 10^{-6} \mathrm{ft}^{-1}$ for the 1996 simulation period was used for this simulation. Similar to 1996 , canal-flow transmission losses occurred only in canals south of the RC Canal.

\section{Ground-Water Discharge to Ponds}

No monthly data for ground-water discharge to ponds were available for the simulation period. The study conducted using MODFLOW by Marios Sophocleous (Kansas Geological Survey, written commun., 1996) shows that the amount of annual ground-water discharge to ponds on the refuge was almost the same from 1975 through 1990 . Consequently, the monthly ground-water-discharge data obtained from Marios Sophocleous (Kansas Geological Survey, written commun., 1997) for 1994 were used (see table 2). 

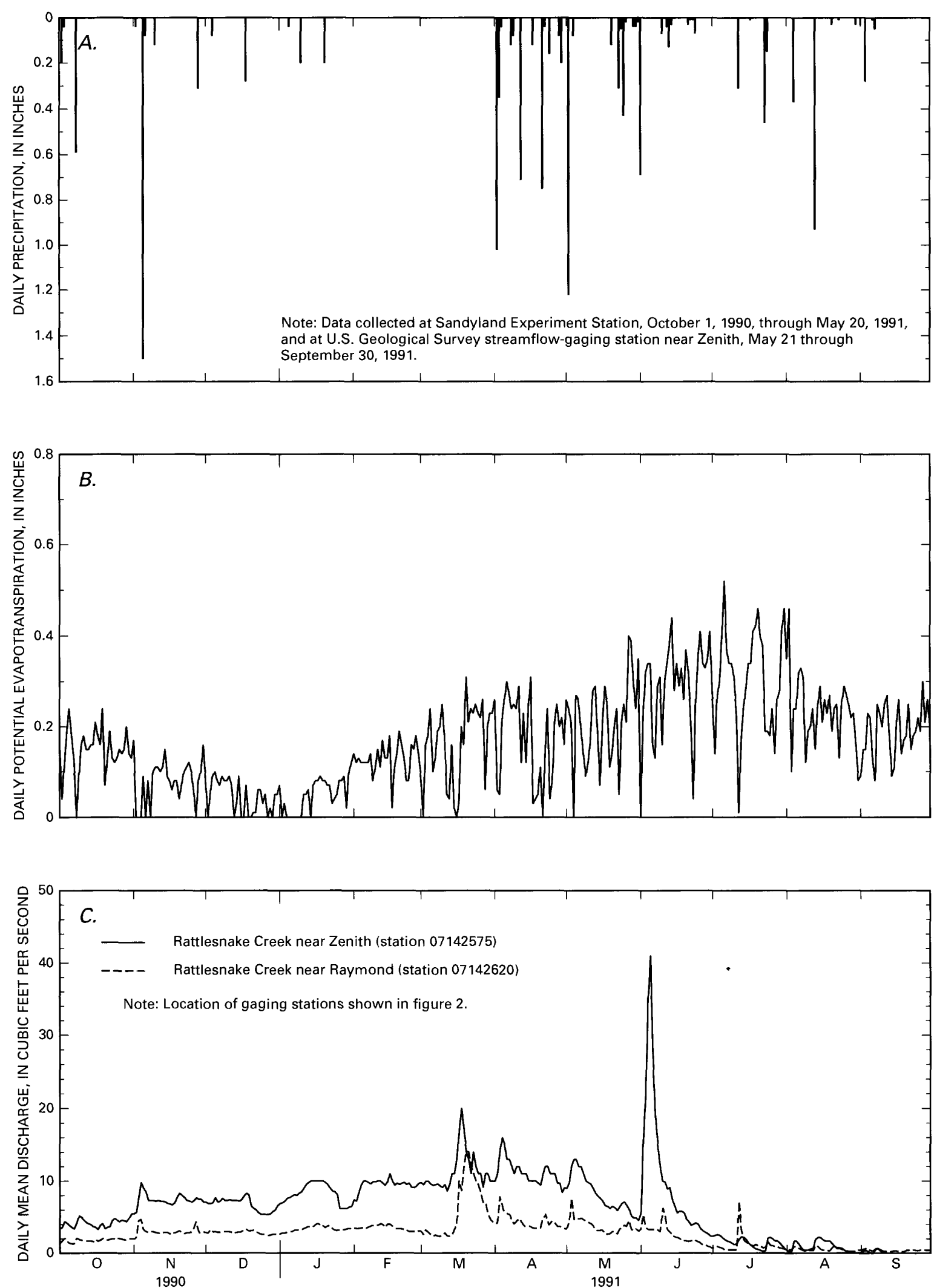

Figure 13. (A) Daily precipitation, (B) daily potential evapotranspiration, and (C) daily mean discharge for Rattlesnake Creek, 1991 water year. Part of the precipitation data and potential evapotranspiration data are from the Kansas Geological Survey (Marios Sophocleous, written commun., 1996), and the discharge data are from Geiger and others (1992). 


\section{Initial Water Storage in Ponds}

The amount of initial water storage in the control ponds affects the operation of the ponds and the final water budgets. The amount of water stored in the control ponds on September 30, 1990, was not known. The 1991 water year simulation was used to evaluate the daily operation of ponds with different rule curves during drought conditions. Therefore, the initial water storage in a pond was simply set at 80 percent of full-pond capacity for the 1991 simulation (see table 12) to be consistent with the study by Marios Sophocleous (Kansas Geological Survey, written commun., 1996).

\section{Pond Zoning and Operating Policy}

Each control pond was divided into four storage zones-inactive zone, lower zone, upper zone, and extended upper zone as shown in figure 5. Normal operating storage of a pond consisted of water stored between the lower zone and upper zone and was set between 20 and 100 percent of full-pond storage capacity for this simulation. In the other words, the lower boundary of the lower storage zone was set at 20 percent of full-pond capacity, and the top boundary of the upper storage zone was set at 100 percent of full-pond capacity. The rule curve was set within this operating storage range. Four different rule curves corresponding to different simulations were set at $60,70,80$, and 90 percent of full-pond capacity, respectively. The capacity of the inactive zone of a pond was set at 20 percent of full-pond storage capacity (selected in consultation with the U.S. Fish and Wildlife Service). The top boundary of the extended upper zone was set $0.5 \mathrm{ft}$ higher than corresponding full-pond capacity. Pond zoning expressed as pond storage along with the rule curve at 90 percent of full-pond capacity are summarized in table 12.

The priority of pond operation for the 1991 water year was the same as for 1996 (see the discussion of pond priority for the 1996 simulation). Typical values for penalty coefficients used in the 1991 water year simulation are also summarized in table 12 . The canal-flow zoning and the assignment of penalty coefficients were the same as those used in the simulation for 1996 (see table 9).

\section{Results}

Four different simulations of canal and control-pond operation at the refuge were conducted with the rule curve of a pond set at $60,70,80$, and 90 percent of full-pond capacity, respectively. Other specifications for pond zoning and canal outflows from the refuge were (1) the initial storage of a pond was set at the 80 percent of full-pond capacity; (2) the inactive storage of a pond was set at the 20 percent of full-pond capacity; and (3) outflows of Rattlesnake Creek near the USGS streamflow-gaging station near Raymond were fixed and equal to the discharges observed for the 1991 water year.

Results of operating the canals and control ponds using a rule curve of 90 percent of full-pond capacity are described first. The simulated water budget for water unit 5 is shown in figure 14. Figure 14A shows the inflows from the upstream Zenith node to water unit 5 (also see figure 4), which are equal to the discharges observed at the USGS streamflow-gaging station near Zenith. The total releases to all downstream nodes (water units 7 and 10A, and canal joints $C-2$ and JE-1) from unit 5 are shown in figure $14 C$. The simulated pond water stage corresponding to water storage (fig. 14D) is shown in figure $14 E$. Similar figures could also be generated for the remaining control ponds. These figures reflect the operation of a single pond during an entire simulation period with the current operating policy. These figures also can be used to evaluate whether some specifications, such as the target water level, in the operating policy are satisfied. Water storage after mid-June 1991 decreased and reached the inactive zone (fig. 14D) and could not be maintained at the target level due to insufficient inflow and water-surface evaporation. In other words, if the target level in water unit 5 was set too low, water unit 5 could be dry at the end of the period under inflow conditions that were simulated.

To show the water budget of a control pond during the simulation period, table 13 summarizes water-budget components of ponds with the rule curve at 90 percent of full-pond capacity. It is seen from table 13 that the final storage value for all ponds at the end of the simulation period was much smaller than the initial storage values. Many small ponds were dry at the end of the simulation period. Total water-surface evaporation for all ponds was much larger than other water-budget components (runoff, ground-water seepage). 
Table 12. Initial storage, rule curve, zoning, and penalty coefficients assigned to control ponds at Quivira National Wildlife Refuge, 1991 water year

[acre-ft, acre-feet]

\begin{tabular}{|c|c|c|c|c|c|c|c|c|c|c|}
\hline $\begin{array}{l}\text { Water- } \\
\text { unit } \\
\text { number } \\
\text { (fig. 2) }\end{array}$ & $\begin{array}{c}\text { Initial } \\
\text { storage } \\
\text { at } 80 \\
\text { percent } \\
\text { of full- } \\
\text { pond } \\
\text { capacity } \\
\text { (acre-ft) }\end{array}$ & $\begin{array}{c}\text { Rule } \\
\text { curve at } \\
90 \\
\text { percent } \\
\text { of full- } \\
\text { pond } \\
\text { capacity } \\
\text { (acre-ft) }\end{array}$ & $\begin{array}{c}\text { Upper } \\
\text { boundary } \\
\text { of } \\
\text { extended } \\
\text { upper } \\
\text { zone } \\
\text { (acre-ft) }\end{array}$ & $\begin{array}{l}\text { Penalty } \\
\text { coeffi- } \\
\text { cient for } \\
\text { extended } \\
\text { upper } \\
\text { zone }\end{array}$ & $\begin{array}{c}\text { Upper } \\
\text { boundary } \\
\text { of upper } \\
\text { zone } \\
\text { (acre-ft) }\end{array}$ & $\begin{array}{l}\text { Penalty } \\
\text { coeffi- } \\
\text { cient for } \\
\text { upper } \\
\text { zone }\end{array}$ & $\begin{array}{l}\text { Lower } \\
\text { boundary } \\
\text { of lower } \\
\text { zone } \\
\text { (acre-ft) }\end{array}$ & $\begin{array}{l}\text { Penalty } \\
\text { coeffi- } \\
\text { cient for } \\
\text { lower } \\
\text { zone }\end{array}$ & $\begin{array}{c}\text { Lower } \\
\text { boundary } \\
\text { of } \\
\text { inactive } \\
\text { zone } \\
\text { (acre-ft) }\end{array}$ & $\begin{array}{l}\text { Penalty } \\
\text { coeffi- } \\
\text { cient for } \\
\text { inactive } \\
\text { zone }\end{array}$ \\
\hline 5 & $1,492.80$ & $1,679.40$ & $2,312.18$ & 3,000 & $1,866.00$ & 2,000 & 373.20 & 3,000 & 0 & 6,000 \\
\hline 7 & 32.00 & 36.00 & 54.49 & 3,000 & 40.00 & 1,500 & 8.00 & 1,500 & 0 & 3,000 \\
\hline $10 \mathrm{~A}$ & 116.00 & 130.50 & 180.30 & 3,000 & 145.00 & 1,500 & 29.00 & 1,500 & 0 & 3,000 \\
\hline $10 \mathrm{~B}$ & 116.00 & 130.50 & 180.30 & 3,000 & 145.00 & 1,500 & 29.00 & 1,500 & 0 & 3,000 \\
\hline $10 \mathrm{C}$ & 10.40 & 11.70 & 14.61 & 3,000 & 13.00 & 1,500 & 2.60 & 1,500 & 0 & 3,000 \\
\hline 11 & 270.40 & 304.20 & 413.90 & 3,000 & 338.00 & 1,500 & 67.60 & 1,500 & 0 & 3,000 \\
\hline $14 \mathrm{~A}$ & 156.80 & 176.40 & 242.20 & 3,000 & 196.00 & 1,500 & 39.20 & 1,500 & 0 & 3,000 \\
\hline $14 B$ & 76.80 & 86.40 & 144.01 & 3,000 & 96.00 & 1,500 & 19.20 & 1,500 & 0 & 3,000 \\
\hline $14 \mathrm{C}$ & 12.80 & 14.40 & 19.07 & 3,000 & 16.00 & 1,500 & 3.20 & 1,500 & 0 & 3,000 \\
\hline 16 & 64.00 & 72.00 & 96.07 & 3,000 & 80.00 & 1,500 & 16.00 & 1,500 & 0 & 3,000 \\
\hline $20 \mathrm{~A}$ & 156.00 & 175.50 & 268.01 & 3,000 & 195.00 & 1,500 & 39.00 & 1,500 & 0 & 3,000 \\
\hline $20 \mathrm{~B}$ & 156.00 & 175.50 & 268.01 & 3,000 & 195.00 & 1,500 & 39.00 & 1,500 & 0 & 3,000 \\
\hline 21 & 64.80 & 72.90 & 96.62 & 3,000 & 81.00 & 1,500 & 16.20 & 1,500 & 0 & 3,000 \\
\hline 22 & 10.40 & 11.70 & 18.81 & 3,000 & 13.00 & 1,500 & 2.60 & 1,500 & 0 & 3,000 \\
\hline 23 & 12.00 & 13.50 & 19.66 & 3,000 & 15.00 & 1,500 & 3.00 & 1,500 & 0 & 3,000 \\
\hline 24 & 28.00 & 31.50 & 53.04 & 3,000 & 35.00 & 1,500 & 7.00 & 1,500 & 0 & 3,000 \\
\hline 25 & 236.80 & 266.40 & 344.05 & 3,000 & 296.00 & 1,500 & 59.20 & 1,500 & 0 & 3,000 \\
\hline 26 & 88.80 & 99.90 & 142.39 & 3,000 & 111.00 & 1,500 & 22.20 & 1,500 & 0 & 3,000 \\
\hline 28 & 122.40 & 137.70 & 198.82 & 3,000 & 153.00 & 1,500 & 30.60 & 1,500 & 0 & 3,000 \\
\hline 29 & 72.80 & 81.90 & 124.51 & 3,000 & 91.00 & 1,500 & 18.20 & 1,500 & 0 & 3,000 \\
\hline 30 & 95.20 & 107.10 & 161.64 & 3,000 & 119.00 & 1,500 & 23.80 & 1,500 & 0 & 3,000 \\
\hline 40 & 52.80 & 59.40 & 83.19 & 3,000 & 66.00 & 1,500 & 13.20 & 1,500 & 0 & 3,000 \\
\hline 48 & 90.40 & 101.70 & 161.19 & 3,000 & 113.00 & 1,500 & 22.60 & 1,500 & 0 & 3,000 \\
\hline 49 & 127.20 & 143.10 & 209.05 & 3,000 & 159.00 & 1,500 & 31.80 & 1,500 & 0 & 3,000 \\
\hline 57 & 169.60 & 190.80 & 280.74 & 3,000 & 212.00 & 1,500 & 42.40 & 1,500 & 0 & 3,000 \\
\hline 58 & 200.80 & 225.90 & 302.82 & 3,000 & 251.00 & 1,500 & 50.20 & 1,500 & 0 & 3,000 \\
\hline 61 & 398.40 & 448.20 & 613.17 & 3,000 & 498.00 & 1,500 & 99.60 & 1,500 & 0 & 3,000 \\
\hline 62 & 96.00 & 108.00 & 145.00 & 3,000 & 120.00 & 1,500 & 24.00 & 1,500 & 0 & 3,000 \\
\hline 63 & 271.20 & 305.10 & 419.01 & 3,000 & 339.00 & 1,500 & 67.80 & 1,500 & 0 & 3,000 \\
\hline 75 & $1,956.80$ & $2,201.40$ & $3,490.32$ & 3,000 & $2,446.00$ & 1,500 & 489.20 & 1,500 & 0 & 3,000 \\
\hline 78 & $4,216.00$ & $4,743.00$ & $6,091.37$ & 2,000 & $5,270.00$ & 1,000 & $1,054.00$ & 1,000 & 0 & 3,000 \\
\hline 80 & 284.00 & 319.50 & 474.34 & 2,000 & 355.00 & 1,000 & 71.00 & 1,000 & 0 & 3,000 \\
\hline 81 & 20.00 & 22.50 & 60.68 & 2,000 & 25.00 & 1,000 & 5.00 & 1,000 & 0 & 3,000 \\
\hline 83 & 251.20 & 282.60 & 419.31 & 3,000 & 314.00 & 1,500 & 62.80 & 1,500 & 0 & 3,000 \\
\hline
\end{tabular}



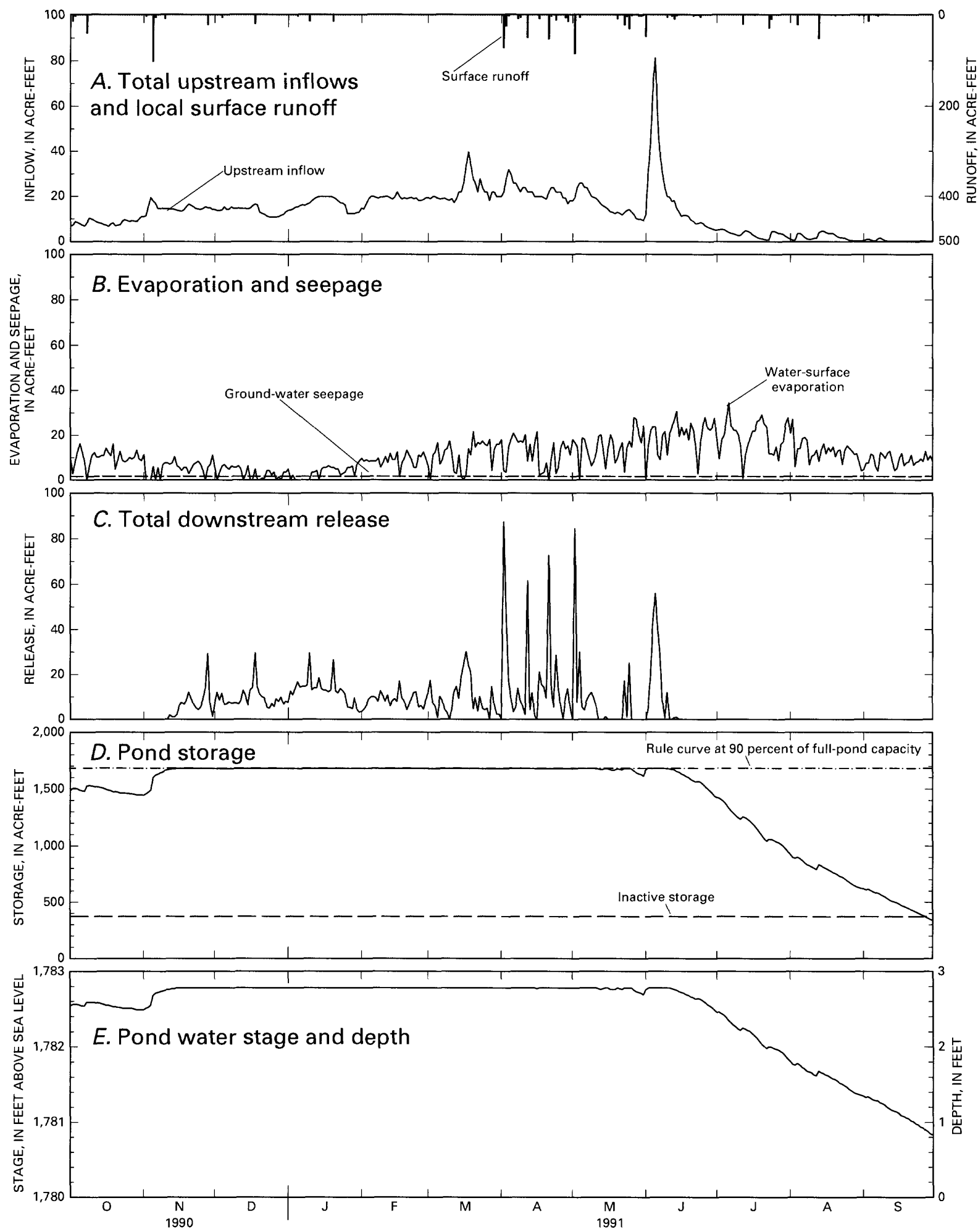

Figure 14. Water budget simulated for water unit 5, 1991 water year. 
Table 13. Water budgets simulated for control ponds at Quivira National Wildlife Refuge with rule curve at 90 percent of full-pond capacity, 1991 water year

[All values are in acre-feet; --, not applicable]

\begin{tabular}{|c|c|c|c|c|c|c|c|}
\hline $\begin{array}{l}\text { Water-unit } \\
\text { number } \\
\text { (fig. 2) }\end{array}$ & $\begin{array}{c}\text { Initial } \\
\text { storage at } 80 \\
\text { percent of } \\
\text { fuil-pond }+ \\
\text { capacity }\end{array}$ & $\begin{array}{c}\text { Total } \\
+\begin{array}{c}\text { upstream } \\
\text { inflow }\end{array}\end{array}$ & $\begin{array}{c}+ \text { Total surface } \\
\text { runoff }\end{array}$ & $\begin{array}{c}\text { Water- } \\
\text { surface } \\
\text { evaporation }\end{array}$ & $\begin{array}{c}\begin{array}{c}\text { Ground- } \\
\text { water }\end{array} \\
\text { seepage }^{1}\end{array}$ & $\begin{array}{c}\text { Total } \\
\text { - downstream } \\
\text { release }\end{array}=$ & $=$ \\
\hline 5 & $1,492.80$ & $4,772.63$ & 900.16 & $3,970.32$ & 545.66 & $2,312.24$ & 337.37 \\
\hline 7 & 32.00 & 27.62 & 17.03 & 60.87 & 0 & 15.78 & 0 \\
\hline $10 \mathrm{~A}$ & 116.00 & 81.59 & 48.37 & 196.59 & 0 & 41.33 & 8.04 \\
\hline $10 \mathrm{~B}$ & 116.00 & 56.16 & 31.97 & 132.51 & 64.84 & 6.78 & 0 \\
\hline $10 \mathrm{C}$ & 10.40 & 6.68 & 5.53 & 22.61 & 0 & 0 & 0 \\
\hline 11 & 270.40 & 0 & 41.11 & 175.91 & 0 & 0 & 135.60 \\
\hline $14 \mathrm{~A}$ & 156.80 & 117.93 & 67.12 & 252.34 & 0 & 80.85 & 8.66 \\
\hline $14 B$ & 76.80 & 64.16 & 44.27 & 171.41 & -18.25 & 27.51 & 4.56 \\
\hline $14 \mathrm{C}$ & 12.80 & 56.63 & 5.13 & 17.70 & 24.97 & 31.89 & 0 \\
\hline 16 & 64.00 & 48.64 & 19.21 & 72.22 & 0 & 54.60 & 5.03 \\
\hline $20 \mathrm{~A}$ & 156.00 & 100.37 & 78.10 & 303.93 & 0 & 29.97 & .57 \\
\hline $20 \mathrm{~B}$ & 156.00 & 196.85 & 96.66 & 380.01 & 13.88 & 55.62 & 0 \\
\hline 21 & 64.80 & 51.83 & 22.11 & 85.13 & 0 & 50.50 & 3.11 \\
\hline 22 & 10.40 & 50.07 & 6.45 & 23.09 & 0 & 43.83 & 0 \\
\hline 23 & 12.00 & 43.62 & 6.40 & 23.31 & 0 & 38.71 & 0 \\
\hline 24 & 28.00 & $1,541.96$ & 17.28 & 62.83 & 149.33 & $1,375.08$ & 0 \\
\hline 25 & 236.80 & 94.39 & 73.72 & 268.01 & 75.04 & 61.85 & .01 \\
\hline 26 & 88.80 & 99.09 & 30.52 & 121.74 & 13.50 & 83.17 & 0 \\
\hline 28 & 122.40 & 61.71 & 44.38 & 172.26 & 0 & 53.03 & 3.20 \\
\hline 29 & 72.80 & 51.45 & 31.35 & 123.71 & 0 & 30.83 & 1.06 \\
\hline 30 & 95.20 & 30.25 & 42.70 & 167.16 & 0 & .99 & 0 \\
\hline 40 & 52.80 & 0 & 30.79 & 134.70 & -86.83 & 8.19 & 27.53 \\
\hline 48 & 90.40 & 35.50 & 43.20 & 167.99 & 0 & .12 & .99 \\
\hline 49 & 127.20 & 45.13 & 52.38 & 205.68 & 19.03 & 0 & 0 \\
\hline 57 & 169.60 & 343.12 & 114.11 & 485.65 & 0 & 102.75 & 38.43 \\
\hline 58 & 200.80 & 362.88 & 92.46 & 394.82 & -173.34 & 390.50 & 44.16 \\
\hline 61 & 398.40 & 565.28 & 208.54 & 902.49 & -109.08 & 283.94 & 94.87 \\
\hline 62 & 96.00 & 0 & 40.37 & 173.96 & -70.19 & 3.15 & 29.45 \\
\hline 63 & 271.20 & 189.92 & 150.50 & 650.00 & -161.39 & 59.07 & 63.94 \\
\hline 75 & $1,956.80$ & 254.24 & $1,478.91$ & $6,103.74$ & $-5,002.59$ & $1,642.84$ & 945.96 \\
\hline 78 & $4,216.00$ & $1,881.86$ & $1,262.39$ & $5,406.83$ & -587.57 & $1,486.99$ & $1,054.00$ \\
\hline 80 & 284.00 & $2,028.75$ & 147.51 & 646.47 & -172.74 & $1,915.53$ & 71.00 \\
\hline 81 & 20.00 & $1,486.99$ & 37.92 & 162.60 & -651.44 & $2,028.75$ & 5.00 \\
\hline 83 & 251.20 & 0 & 133.69 & 522.11 & -137.75 & 0 & .53 \\
\hline Total & $11,525.60$ & -- & $5,422.34$ & $22,760.70$ & $-6,264.92$ & -. & 2,883.07 \\
\hline
\end{tabular}

${ }^{1}$ The positive values of ground-water seepage indicate that ponds lost water to the aquifer. The negative values of ground-water seepage indicate that ponds gained water from the aquifer. 
Table 14. Water budget simulated for entire canal and control-pond system at Quivira National Wildlife Refuge with rule curve at 90 percent of full-pond capacity, 1991 water year

[All values are in acre-feet; --, not applicable]

\begin{tabular}{lccc}
\hline $\begin{array}{c}\text { Water-budget } \\
\text { component }\end{array}$ & Storage & infiow & Outfiow \\
\hline Initial storage & $11,525.60$ & -- & -- \\
Stream inflow & -- & $4,772.63$ & -- \\
Surface runoff & -- & $5,422.34$ & -- \\
Water-surface & -- & -- & $22,760.70$ \\
evaporation & & & \\
Net ground-water & -- & $6,264.92$ & -- \\
seepage & & & \\
$\begin{array}{l}\text { Canal-flow } \\
\text { transmission loss }\end{array}$ & -- & -- & 336.51 \\
$\begin{array}{l}\text { Outflow from } \\
\text { Raymond node }\end{array}$ & -- & -- & $2,005.24$ \\
Final storage & $\mathbf{2 , 8 8 3 . 0 7}$ & -- & -- \\
\hline
\end{tabular}

To examine the water budget for the whole flow system at the refuge, table 14 summarizes the overall water budget for the entire canal and control-pond system with the rule curve set at 90 percent of full-pond capacity. It can be seen from this table that although there were total inflows of $16,459.89$ acre- $\mathrm{ft}$, of which 4,772.63 acre-ft were from Rattlesnake Creek at Zenith node, 5,422.34 acre-ft from direct surface runoff, and $6,264.92$ acre-ft from the ground-water seepage to ponds, the final water storage in the system was substantially reduced from the initial storage of $11,525.60$ acre-ft, which was set at 80 percent of full-pond capacity, to $2,883.07$ acre-ft due to the outflows from the Raymond node, water-surface evaporation, and canal-flow transmission loss. Total water out of the system (outflow, evaporation, and canal-flow transmission loss) from the system was $25,102.45$ acre-ft, of which 22,760.70 acre-ft (or 91 percent of water outflow from the system) was due to water-surface evaporation. At the end of simulation period, 30 out of 34 ponds, including water unit 5 , had water stored only in the inactive zone or were dry due to the large amount of water-surface evaporation.

To compare the operation of canal and control ponds with the rule curve at 90 percent of full-pond capacity, simulations were also conducted with the rule curves at 80,70, and 60 percent of full-pond capacity. All of simulations were conducted with the same model specification except for the rule curves.
Figure 15 shows the change in water storage for water units 5 and 78, respectively, with different rule curves. As the rule curve was reduced from 90 to 60 percent of full-pond capacity, water storage in water unit 5 during the simulation period decreased, and the final pond storage was also reduced from 337 to 48 acre-ft (fig. $15 A)$. Because water unit 5 had the highest priority and because the initial storage was higher than the rule curve, water was released immediately downstream as shown in figure $15 \mathrm{~A}$. On the other hand, water storage in water unit 78 increased during the simulation period (fig. 15B). Because water unit 78 had the lowest priority and because water storage in the upstream higher priority ponds was in the upper zone, water was released from these higher priority ponds to maintain their rule curves, and water released from the upstream pond was stored in the unit 78 , which caused the water storage to reach full-pond capacity (fig. 15B). After mid-June 1991, there were not enough inflow (upstream inflow plus surface runoff) to water unit 5 to maintain water levels at the rule curve, and water levels decreased due to water-surface evaporation. At the end of simulation, the water level in water unit 5 was located in the inactive zone (figs. 14 and 15A). Similar changes in water storages were also observed for other control ponds.

The simulated water budget for the entire canal and control-pond system for the 1991 water year with different rule curves is summarized in table 15 . As the rule curves were reduced from 90 to 60 percent of full-pond capacity, surface runoff, water-surface evaporation, and ground-water seepage from ponds were reduced, and stream outflow and final storage increased (see table 15). The reduction of the rule curve of a pond generally caused a lower pond water level to be maintained for the higher priority ponds. In other words, the total water-surface evaporation and rainfall onto the water-surface area of a pond were reduced for the same evaporation rate and precipitation depth. When initial pond storage was higher than the rule curve (initial storage was set at 80 percent of full-pond capacity), water was released from the ponds with higher priority to meet the rule-curve water level, which caused more canal-flow transmission losses along the canals in the south part of the refuge and increased outflows from water unit 11 . The final pond water storage also increased due to storage increases in water unit 78 (fig.15B) and other ponds in the north part of the refuge. 

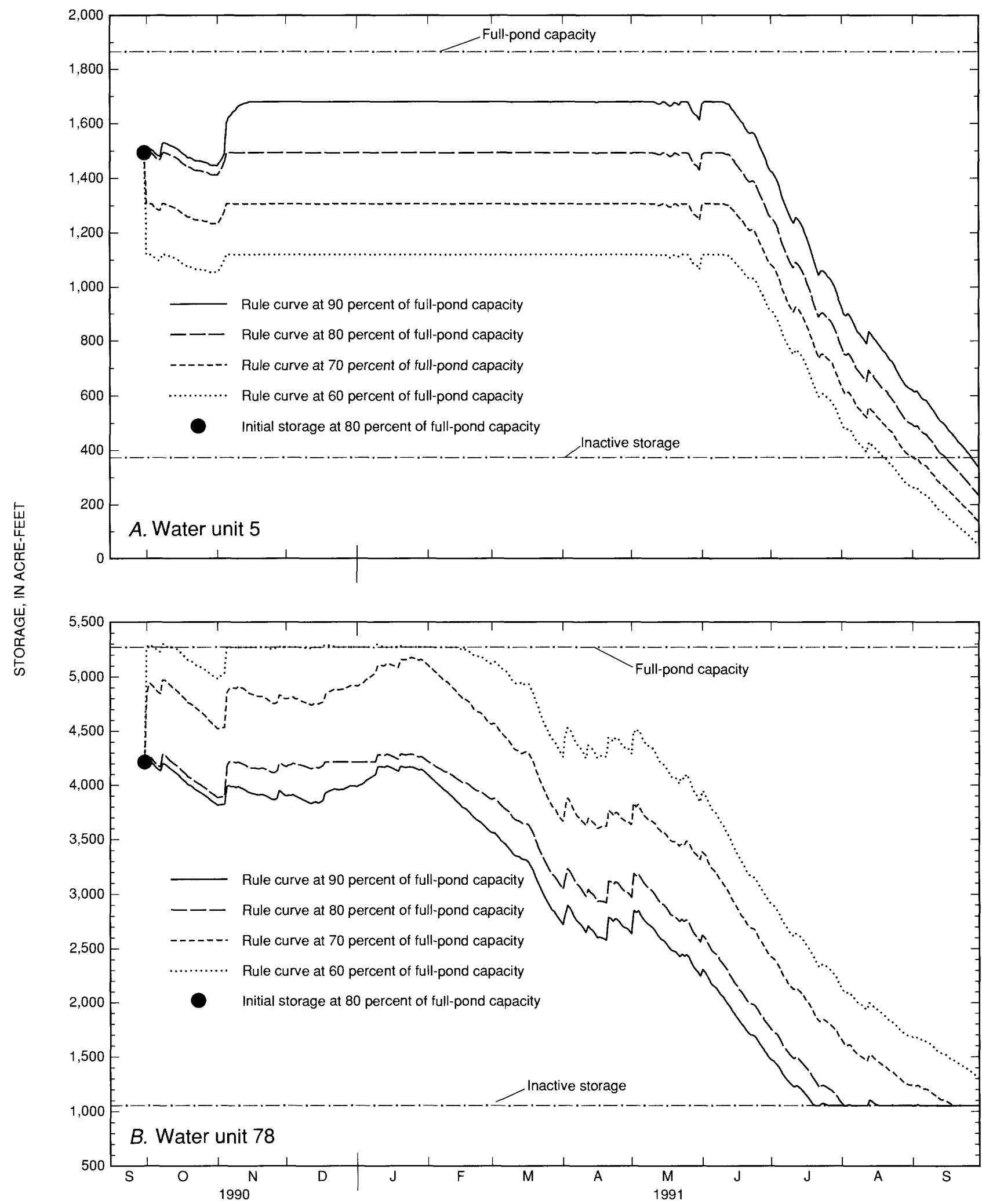

Figure 15. Simulated pond water storage with different rule curves for $(A)$ water unit 5 and $(B)$ water unit 78 , with initial storage at 80 percent of full-pond capacity, 1991 water year. 
Table 15. Water budgets simulated for entire canal and control-pond system at Quivira National Wildlife Refuge using different rule curves, 1991 water year

[all values are in acre-feet]

\begin{tabular}{lcccc}
\hline $\begin{array}{c}\text { Water-budget } \\
\text { component }\end{array}$ & $\begin{array}{c}\text { Rule curve set at } \\
90 \text { percent of } \\
\text { full-pond capacity }\end{array}$ & $\begin{array}{c}\text { Rule curve set at } \\
80 \text { percent of } \\
\text { full-pond capacity }\end{array}$ & $\begin{array}{c}\text { Rule curve set at } \\
\mathbf{7 0} \text { percent of } \\
\text { full-pond capacity }\end{array}$ & $\begin{array}{c}\text { Rule curve set at } \\
60 \text { percent of } \\
\text { full-pond capacity }\end{array}$ \\
\hline $\begin{array}{l}\text { Initial pond storage } \\
\text { Inflow: }\end{array}$ & $11,525.60$ & $11,525.60$ & $11,525.60$ & $11,525.60$ \\
$\begin{array}{l}\text { Stream inflow from Rat- } \\
\text { tlesnake Creek }\end{array}$ & $4,772.63$ & $4,772.63$ & $4,772.63$ & $4,772.63$ \\
$\begin{array}{l}\text { Surface runoff } \\
\text { Net ground-water seep- } \\
\text { age, including canal- } \\
\text { flow transmission loss }\end{array}$ & $5,422.34$ & $5,393.31$ & $5,260.83$ & $4,981.23$ \\
Outflow: & $-5,928.41$ & $-5,900.37$ & $-5,854.23$ & $-5,854.04$ \\
$\begin{array}{l}\text { Water-surface } \\
\text { evaporation }\end{array}$ & $22,760.70$ & & & \\
Total outflow & $2,005.24$ & $2,694.41$ & $22,238.25$ & $21,299.74$ \\
& & $2,005.28$ & $2,073.30$ & $2,547.26$ \\
Final pond storage & $\mathbf{2 , 8 8 3 . 0 7}$ & $\mathbf{2 , 8 9 2 . 2 2}$ & $\mathbf{3 , 1 0 1 . 7 4}$ & $\mathbf{3 , 2 8 6 . 5 0}$ \\
\hline
\end{tabular}

Simulation results for the 1991 water year indicate that water-surface evaporation was the major factor in lowering water storage in ponds. Storing more water in the ponds in the north part of the refuge by reducing the rule curve for higher priority ponds may reduce the overall water-surface evaporation. However, this will also cause water unit 5 to dry out quickly if there is not enough upstream inflow as was the case during the 1991 water year. Maintaining high water levels in water unit 5 depends upon the rule curve in water unit 5 being set at a high level. The simulation results discussed for the 1991 water year were obtained based on a number of assumptions, such as the initial storage in ponds. If the specifications for the simulation model change, the results may be much different.

\section{SUMMARY}

In 1995, a 3-year study was undertaken to develop a water budget and flow-routing model to assist the U.S. Fish and Wildlife Service in determining the outcome of possible water-management options at the Quivira National Wildlife Refuge, south-central Kansas. The study was done by the U.S. Geological Survey in cooperation with the Kansas Geological Survey. A computer program OPONDS, written in FORTRAN, was developed using network flow analysis to determine the optimal operation of a system of canals and control ponds. Applications of the model are presented that investigate the daily operation of canals and control ponds on the refuge using historical discharge and pond water levels.

The daily operation of a system of canals and control ponds at the refuge in the Rattlesnake Creek Basin was simulated for June 11 through December 11, 1996, using a linear-network flow model. In this simulation, some management requirements included the measured water levels of control ponds as the target management pond levels and the observed stream discharges in Rattlesnake Creek near Raymond as the outflow requirement from the refuge. Measured precipitation and calculated potential evapotranspiration were used to compute the surface runoff to ponds and water-surface evaporation, respectively. The operating policy was determined by using selected storage zones within a pond and prioritization of the ponds by using the relative magnitude of penalty coefficients within the computer model to adjust pond storages and canal flows. Results of the 1996 simulation indicate that the current specification for pond zoning and rule curves, with water unit 5 given the highest priority and ponds in the north part of the refuge given the lowest priori- 
ties, simulated pond levels that matched well with observed ones. Root mean square errors between simulated and measured water levels were less than $0.13 \mathrm{ft}$ except for water units 24 and 30 . Water storage in ponds during the simulation period was substantially reduced due to water-surface evaporation and canal-flow transmission losses.

Simulation of canal and control-pond operation under drought conditions during the 1991 water year was also conducted with different target pond water levels. This simulation used 1991 measured stream discharges, precipitation, and potential evapotranspiration data and 1994 ground-water seepage to ponds to investigate the operation of the canals and control ponds. The operating policy used four pond storage zones and the prioritization of ponds, with water unit 5 having the highest priority and ponds in the north part of the refuge having the lowest priority. Results showed that under the same initial water storage of 80 percent of full-pond capacity lowering target pond water levels reduced water-surface evaporation, resulted in more water stored in ponds in the north part of the refuge, and caused a substantial decrease in the final water storage in water unit 5 . In other words, to maintain high water storage in water unit 5 , the target water level in this unit should be high. To reduce the total water-surface evaporation loss, the target water level should be low for unit 5 so that water is stored in the ponds in the north part of the refuge. It should be noted that results of the 1991 water year simulation were obtained with the same initial storage of ponds and measured discharges of Rattlesnake Creek near Raymond as the 1996 simulation. The optimal operation of a system of canals and control ponds depends on having a well-defined operating policy and accurate data and may require several combinations of model specifications to obtain optimum results.

The OPONDS model can be applied to other operations at the Quivira Refuge simply by modifying the conceptual flow-network configuration and changing the operating policy through pond-storage and canal-flow zoning and corresponding penalty coefficients. The OPONDS model can be applied to operational matters such as the determination of target water levels and pond water releases, the operation of the outlet structures, and canal flow and routing.

The OPONDS model is a simplification of a complex canal-pond network flow system and is limited in simulating the operation of the flow system by the accuracy of data used in the model and some assump- tions. Nonetheless, the OPONDS model is a useful tool for estimating the effects of possible water-management options for the Quivira National Wildlife Refuge.

\section{REFERENCES}

Bazaraa, M.S., Jarvis, J.J., and Sherali, H.D., 1990, Linear programming and network flows (2nd ed.): New York, John Wiley \& Sons, 684 p.

Chengdu Science and Technology University, 1979, Hydraulics: Chengdu, China, Chengdu Science and Technology University, $512 \mathrm{p}$.

Chow, V.T., Maidment, D.R., and Mays, L.W., 1988, Applied hydrology: New York, McGraw-Hill, Inc., $572 \mathrm{p}$.

Fulkerson, D.R., 1961, An out-of-kilter method for minimal cost flow problem: Journal of the Society for Industrial and Applied Mathematics, v. 9, p.18-27.

Geiger, C.O, Lacock, D.L., Schneider, D.R., Carlson, M.D., and Pabst, B.J., 1992, Water resources data, Kansas, water year 1991: U.S. Geological Survey Water-Data Report KS-91-1, 358 p.

Henderson, F.M., 1966, Open channel flow: New York, MacMillan Publ. Co., Inc., 522 p.

Hulsing, Harry, 1967, Measurement of peak discharge at dams by indirect method: U.S. Geological Survey Techniques of Water-Resources Investigations, book 3, chap. A5, 29 p.

Jian, Xiaodong, 1988, Simulation and optimization of the operation of the Kansas River Basin reservoirs:

Lawrence, University of Kansas, unpublished master's thesis, $121 \mathrm{p}$.

Jordan, P.R., 1977, Streamflow transmission losses in western Kansas: American Society of Civil Engineers, Journal of the Hydraulic Division, v. 103, no. HY8, p. 905-919.

McCuen, R.H., 1989, Hydrologic analysis and design: Englewood Cliffs, New Jersey, Prentice-Hall, 867 p.

Putnam, J.E., Lacock, D.L., Schneider, D.R., Carlson, M.D., and Dague, B.J., 1996, Water resources data, Kansas, water year 1995: U.S. Geological Survey Water-Data Report KS-95-1, 488 p.

Soil Conservation Service, 1985, SCS national engineering handbook, section 4, hydrology: U.S. Department of Agriculture, various pages.

Sophocleous, Marios, and Perkins, S.P., 1992, Stream-aquifer and mineral intrusion modeling of the lower Rattlesnake Creek basin with emphasis on the Quivira National Wildlife Refuge: Kansas Geological Survey Open-File Report 92-6, 205 p.

Swamee, P.K., 1992, Sluice-gate discharge equations: Journal of Irrigation and Drainage Engineering, v. 118, no. 1, p. 56-60. 
U.S. Army Engineer Waterways Experiment Station, 1972, Overflow spillways, site-discharge relation for uncontrolled flow: Vicksburg, Miss., Hydraulic Design Chart 113-3/3.

Wu, J.S., King, E.L., and Wang, Michael, 1985, Optimal identification of Muskingum routing coefficients: Water Resources Bulletin, v. 21, no. 3, p. 417-421.
Yu, Yun-Sheng, Jian, Xiaodong, Pogge, E.C., and Heidari, Manoutchehr, 1989, Management of the Kansas River Basin-a systems approach phase II: Lawrence, Kansas, Water Resources Research Institute Contribution No. 276, 119 p. 


\section{APPENDICES}




\section{APPENDIX A. GENERAL DESCRIPTION OF OPONDS COMPUTER PROGRAM}

The computer program OPONDS (The optimal Operation of a system of PONDS) is written in FORTRAN 77. The main purpose of the program is to simulate the operation of a system of canals and ponds using various management requirements. Some examples of management requirements are target water levels (rule curves) of ponds, target releases from ponds, minimum required canal flow, maximum allowed canal flow, target water withdrawals, prioritization of ponds, and so forth. The program combines the concepts of pond zoning and rule curves together with the prioritization of ponds to determine operation of a system of canals and ponds using a linear programming technique. The resulting model is very flexible and can be easily adapted to any configuration of a canal-pond system. The introduction of penalty coefficients to the model allows model users to switch easily from one policy of operation to another by simply altering values of the penalty coefficients assigned to prioritize the various ponds.

The modeling approach converts the canal-pond operation into a minimum-cost network flow problem. Some management requirements become constraints in the network flow problem. After the minimum-cost flows are determined, these flows are transferred back to their corresponding pond-storage or canal-flow values.

The overall OPONDS program structure is shown in figure 16. In terms of functions, the whole program can be divided into three parts: (1) build and modify a flow network, (2) determine the flow in the network, and (3) output water budgets in nodes and arcs.

The first part of the program builds a basic flow network. The arcs in this network do not change throughout the simulation period and include pond-storage arcs and canal-flow arcs. For each time period, time-dependent contribution data, such as the net incremental inflow to nodes, precipitation, target water demand, water-surface evaporation, and ground-water seepage, are needed, and arcs representing these contribution data are generated and added into the basic network. If time-dependent management requirements such as seasonal flow boundary and pond rule curves are needed, the basic network can be expanded to represent these time-dependent data.

After the flow network is built, the flows in the network can be determined using a linear network flow algorithm called the out-of-kilter algorithm (Fulkerson, 1961). If no flows can be determined, the program execution terminates.

Once flows are determined for a network, water budgets for canals and ponds are computed. These water budgets are output for each time step. Time-series output of water budgets for selected canals and ponds are also provided.

The program source codes are listed in Appendix E of this report. The electronic form of the source codes may be obtained by contacting the U.S. Geological Survey in Lawrence, Kansas. 


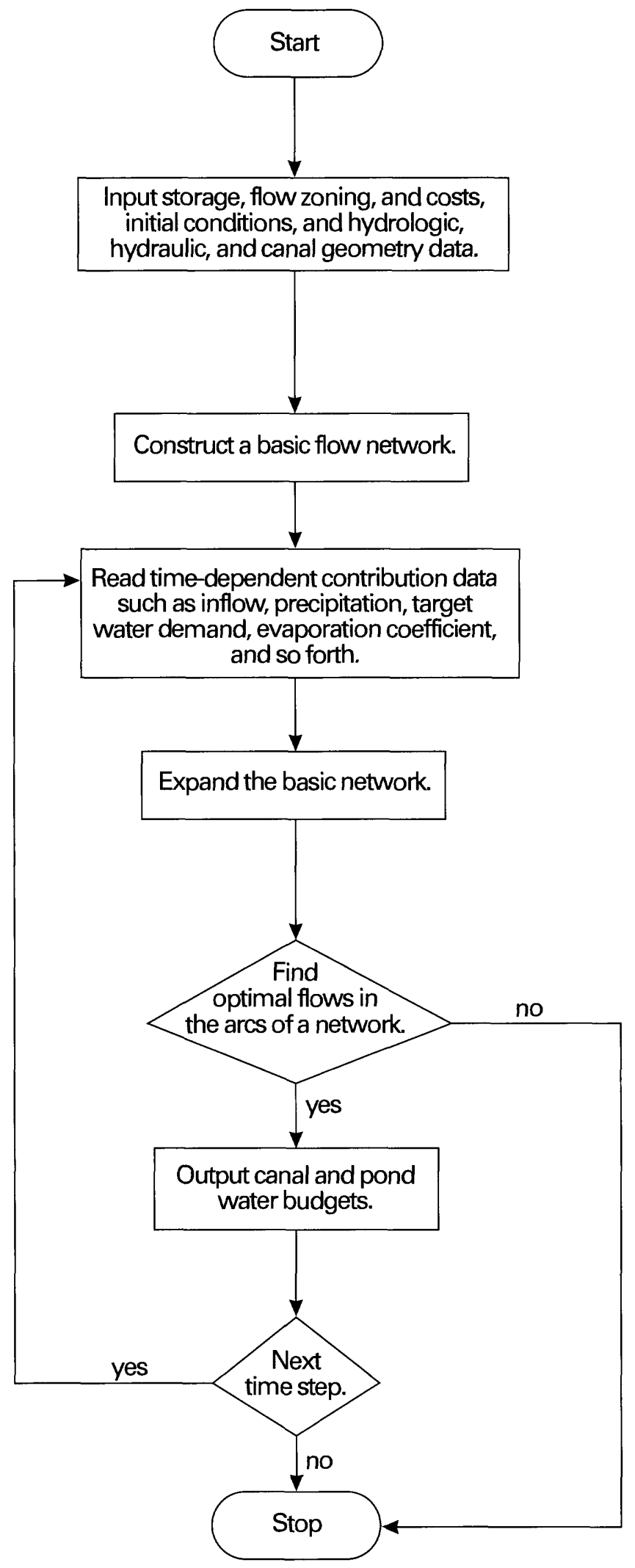

Figure 16. Overall structure of OPONDS computer program. 


\section{APPENDIX B. INPUT/OUTPUT INSTRUCTIONS FOR OPONDS COMPUTER PROGRAM}

Because there are more than 20 input and output data files, all input- and output-data file names and associated file-identification codes are listed in the master data file. File-identification codes here are used to distinguish data files. Table 16 lists all available file-identification codes and descriptions of associated data files. The master data-file format is listed in table 17. Instruction file formats for different input data are summarized in tables 18 through 36. Most input data files consist of four parts of information-title area (five title lines), data unit code, nodal name list, and data matrix. Data are input with free format; that is, the data are delimited by spaces.

The number of input data files is dependent on the study need. The essential files to run the program are the master data file, the general network configuration and parameter file, and the network flow-configuration file if data in this file are not included in the general network configuration and parameter file. The other data files are added only if needed. For example, if a study involves the operation of pond(s), then files for relations of elevation-volume-area of ponds and pond-storage zoning are needed.

Most input data are related to a nodal name. Nodal names are limited to 12 characters and are not case sensitive. For example, POND_1 and pump_1 are valid nodal names. Commas and spaces are not allowed in a nodal name.

Table 16. List of file codes and descriptions for OPONDS computer program

[--, not applicable $]$

\begin{tabular}{|c|c|c|}
\hline $\begin{array}{l}\text { Fiie } \\
\text { code }\end{array}$ & File description & File format \\
\hline \multicolumn{3}{|c|}{ Input data files } \\
\hline 0 & General network configuration and parameter file & See table 18 \\
\hline 1 & Pond zoning file & See table 19 \\
\hline 2 & Network flow-configuration file & See table 20 \\
\hline 3 & Canal geometry file & See table 21 \\
\hline 4 & Outlet hydraulic-structure file & See table 22 \\
\hline 5 & Surface-runoff parameter file & See table 23 \\
\hline 9 & Pond elevation-volume-area file & See tables 24 and 25 \\
\hline 10 & Seasonal target water-demand file & See table 26 \\
\hline 11 & Seasonal water-surface evaporation file & See table 27 \\
\hline 12 & Seasonal flow-boundary file & See table 28 \\
\hline 13 & Seasonal rule-curve file & See table 29 \\
\hline 16 & Local net incremental inflow file & See table 30 \\
\hline 17 & Precipitation file & See table 31 \\
\hline 18 & Time-dependent, evaporation file & See table 32 \\
\hline 19 & Time-dependent, target water-demand file & See table 33 \\
\hline 20 & Time-dependent, rule-curve elevation file & See table 34 \\
\hline 21 & Time-dependent, flow-boundary file & See table 35 \\
\hline 22 & Ground-water-elevation file & See table 36 \\
\hline 23 & Fixed-flow file & See table 37 \\
\hline \multicolumn{3}{|c|}{ Output files } \\
\hline 26 & Network configuration output & -- \\
\hline 27 & Nodal budget output & -- \\
\hline 28 & Arc budget output & -- \\
\hline 29 & Operation of hydraulic-structure output & -- \\
\hline 30 & $\begin{array}{l}\text { File for listing nodal names for nodal water-budget output } \\
\text { in time-series format }\end{array}$ & -- \\
\hline 31 & $\begin{array}{l}\text { File for listing canal upstream and downstream nodal } \\
\text { names for canal water-budget results in time-series } \\
\text { format }\end{array}$ & -- \\
\hline
\end{tabular}


Table 17. File format for master file in OPONDS computer program

[--, not applicable]

\begin{tabular}{cccccccccc}
\hline $\begin{array}{c}\text { State- } \\
\text { ment } \\
\text { number }\end{array}$ & $\begin{array}{c}\text { Informa- } \\
\text { tion at } \\
\text { state- } \\
\text { ment }\end{array}$ & $\begin{array}{c}\text { Vari- } \\
\text { able }\end{array}$ & Definition & $\begin{array}{c}\text { Vari- } \\
\text { able } \\
\text { type }\end{array}$ & $\begin{array}{c}\text { State- } \\
\text { ment } \\
\text { number }\end{array}$ & $\begin{array}{c}\text { Informa- } \\
\text { tion at } \\
\text { state- } \\
\text { ment }\end{array}$ & $\begin{array}{c}\text { Vari- } \\
\text { able }\end{array}$ & Definition & $\begin{array}{c}\text { Vari- } \\
\text { able } \\
\text { type }\end{array}$ \\
\hline $1-5$ & Title lines & -- & $\begin{array}{c}\text { Title and variable } \\
\text { descriptions. }\end{array}$ & -- & 6 & $\begin{array}{c}\text { File code } \\
\text { and file } \\
\text { names }\end{array}$ & $\begin{array}{c}\text { FD } M \\
M\end{array}$ & File code (see & integer \\
table 16). File name. & character
\end{tabular}

The time-series output of water budgets for a node will use the nodal name as a part of the output file name. If the program is running on a personal computer (PC) and time-series output for a nodal water budget is needed, the corresponding nodal name is limited to five characters because a file name, not including the file extension, on PC MS-DOS systems is limited to eight characters.

Seasonal data here mean that values change seasonally (monthly, weekly, even daily) within a year and do not change over years. Some examples of seasonal data are target water demands, pond rule curves (target water level), and evaporation coefficients. These data can be input either as seasonal data or nonseasonal data depending on the length of the simulation period. If the whole simulation period is multiple years, the seasonal data can be specified in the seasonal data file. However, if the simulation period is less than 1 year, seasonal data can be input as nonseasonal data because this may result in smaller input files.

\section{General Network-Configuration and Parameter File}

The general network-configuration and parameter file is used for specifying the basic simulation information, such as length of the simulation period, the number of seasons of a year, and accuracy of output results (see items 1 through 7 in table 18). In addition to the simulation information, data for constructing a basic network, such as pond zoning, canal zoning, canal-flow directions, canal hydrologic and geometry data, and seasonal input data, also can be included in this file. The part numbers are designed to input these data (see instructions in table 18). Note that these data may be specified in separate files (see tables 19 through 23 and 26 through 29).

Table 18. File format for general network configuration and parameters (file-identification code 0 used in OPONDS computer program)

[<, less than; SCS, Soil Conservation Service; $\mathrm{ft}^{3} / \mathrm{s}$, cubic feet per second; $\mathrm{ft}$, feet; $\mathrm{ft}^{3} / \mathrm{d}$, cubic feet per day; ft/d, feet per day; acre-ft, acre-feet; in/d, inch per day; in., inch; $\mathrm{mm} / \mathrm{d}$, millimeter per day; $\mathrm{mm}$, millimeter; --, not applicable; >, greater than; <, less than]

\begin{tabular}{|c|c|c|c|c|c|c|}
\hline $\begin{array}{c}\text { Statement } \\
\text { number }\end{array}$ & $\begin{array}{l}\text { Information at } \\
\text { statement }\end{array}$ & $\begin{array}{l}\text { Variable } \\
\text { name }\end{array}$ & Definition & $\begin{array}{c}\text { Variable } \\
\text { type }\end{array}$ & $\begin{array}{l}\text { Default } \\
\text { value }\end{array}$ & Unit \\
\hline $1-2$ & Title lines & SYSNAM & Canal-pond system name. & character & & \\
\hline 3 & $\begin{array}{l}\text { Time step and } \\
\text { seasons }\end{array}$ & $\begin{array}{l}\text { PERD } \\
\text { NPER }\end{array}$ & $\begin{array}{l}\text { Number of days in a time period. } \\
\text { Number of periods in a year. }\end{array}$ & $\begin{array}{l}\text { real } \\
\text { integer }\end{array}$ & -- & day \\
\hline 4 & Starting season & $\begin{array}{l}\text { STMO } \\
\text { YR }\end{array}$ & $\begin{array}{l}\text { Starting season. } \\
\text { Starting year. }\end{array}$ & $\begin{array}{l}\text { integer } \\
\text { integer }\end{array}$ & -- & $\begin{array}{l}-- \\
--\end{array}$ \\
\hline 5 & $\begin{array}{l}\text { Length of simula- } \\
\text { tion periods }\end{array}$ & NSPS & Number of simulation periods. & & & -- \\
\hline 6 & Convergence & $\begin{array}{l}\text { RTERM } \\
\text { LDIRT }\end{array}$ & $\begin{array}{l}\text { Flow convergence criterion. } \\
\text { Maximum number of iterations. }\end{array}$ & $\begin{array}{l}\text { real } \\
\text { integer }\end{array}$ & -- & $\mathrm{ft}^{3} / \mathrm{s}$ \\
\hline 7 & $\begin{array}{l}\text { Output budget } \\
\text { accuracy }\end{array}$ & $\mathbf{X P}$ & Number of decimal points in acre-ft. & integer & & \\
\hline
\end{tabular}


Table 18. File format for general network configuration and parameters (file-identification code 0 used in OPONDS computer program)-Continued

\begin{tabular}{|c|c|c|c|c|c|c|}
\hline $\begin{array}{l}\text { Statement } \\
\text { number }\end{array}$ & $\begin{array}{c}\text { Information at } \\
\text { statement }\end{array}$ & $\begin{array}{c}\text { Variable } \\
\text { name }\end{array}$ & Definition & $\begin{array}{c}\text { Variable } \\
\text { type }\end{array}$ & $\begin{array}{c}\text { Default } \\
\text { value }\end{array}$ & Unit \\
\hline 8 & Save options & SAVOPT & $\begin{array}{l}\text { Save options for general output }(0-\text { all; } \\
1 \text {-input data; } 2-\text { network configuration; } \\
\text { 9-none). }\end{array}$ & integer & 0 & \\
\hline 9 & $\begin{array}{l}\text { Part 1: } \\
\text { Pond zones and } \\
\text { bottom } \\
\text { information }\end{array}$ & $\begin{array}{l}\text { PART } \\
\text { N }\end{array}$ & $\begin{array}{l}\text { Part. } \\
\text { Part number. }\end{array}$ & $\begin{array}{l}\text { character } \\
\text { integer }\end{array}$ & $\begin{array}{l}\text { PART } \\
1\end{array}$ & -- \\
\hline 10 & List of variables & -- & -- & string & & \\
\hline 11 & Data & $\begin{array}{l}\text { NAME } \\
\text { UNITCD }\end{array}$ & $\begin{array}{l}\text { Pond node name. } \\
\text { Elevation or storage unit code }(0-\mathrm{ft} \text {; } \\
1 \text {-acre- } \mathrm{ft}) \text {. }\end{array}$ & $\begin{array}{l}\text { character } \\
\text { integer }\end{array}$ & -- & -- \\
\hline & & INST & Initial pond elevation or storage. & real & -- & -- \\
\hline & & BOT & Bottom elevation. & real & -- & $\mathrm{ft}$ \\
\hline & & KY & Bottom-bed hydraulic conductivity. & real & -- & $\mathrm{ft} / \mathrm{d}$ \\
\hline & & B & Bottom-bed thickness. & real & -- & $\mathrm{ft}$ \\
\hline & & RC & Rule-curve elevation or storage. & real & -- & -- \\
\hline & & $\mathrm{Z}(\mathrm{I})$ & Zone elevation or storage. & real & -- & -- \\
\hline & & $\begin{array}{l}\operatorname{COST}(\mathrm{I}) \\
\mathrm{I}=1 \\
\mathrm{NZONE}\end{array}$ & $\begin{array}{l}\text { Penalty coefficients. NZONE is the number } \\
\text { of operational storage zones of a pond. }\end{array}$ & integer & -- & -- \\
\hline 12 & Finish & FINISH & Finish. & character & finish & -- \\
\hline 13 & $\begin{array}{l}\text { Part 2: } \\
\text { Flow network }\end{array}$ & $\begin{array}{l}\text { PART } \\
\mathrm{N}\end{array}$ & $\begin{array}{l}\text { Part. } \\
\text { Part number. }\end{array}$ & $\begin{array}{l}\text { character } \\
\text { integer }\end{array}$ & $\begin{array}{l}\text { PART } \\
2\end{array}$ & $\begin{array}{l}-- \\
--\end{array}$ \\
\hline 14 & List of variables & - & -- & string & -- & -- \\
\hline 15 & Data & $\begin{array}{l}\text { F_NODE } \\
\text { T_NODE } \\
\text { LBND } \\
\text { UBND } \\
\text { COST } \\
\text { INST } \\
\text { K } \\
\text { X } \\
\text { SP }\end{array}$ & $\begin{array}{l}\text { From-node name. } \\
\text { To-node name. } \\
\text { Lower flow boundary. } \\
\text { Upper flow boundary. } \\
\text { Penalty coefficient for flow zone. } \\
\text { Initial canal storage. } \\
\text { Traveltime through routing canal. } \\
\text { Weighting factor between } 0 \text { and } 0.5 \text {. } \\
\text { Canal-seepage coefficient }(<1.0) \text {; } \\
\text { if }<0 \text {, use Darcy's law. }\end{array}$ & $\begin{array}{l}\text { character } \\
\text { char } \\
\text { real } \\
\text { real } \\
\text { real } \\
\text { real } \\
\text { real } \\
\text { real } \\
\text { real }\end{array}$ & $\begin{array}{l}-- \\
-- \\
-- \\
-- \\
-- \\
-- \\
-- \\
-- \\
--\end{array}$ & $\begin{array}{l}-- \\
-- \\
\mathrm{ft}^{3} / \mathrm{s} \\
\mathrm{ft}^{3} / \mathrm{s} \\
-- \\
\text { acre-ft } \\
\text { day } \\
-- \\
--\end{array}$ \\
\hline & & EV & Evaporation coefficient. & real & -- & in/d \\
\hline 16 & Finish & FINISH & Finish. & character & finish & -- \\
\hline 17 & $\begin{array}{l}\text { Part 3: Canal } \\
\text { geometry data }\end{array}$ & $\begin{array}{l}\text { PART } \\
\mathbf{N}\end{array}$ & $\begin{array}{l}\text { Part. } \\
\text { Part number. }\end{array}$ & $\begin{array}{l}\text { character } \\
\text { integer }\end{array}$ & $\begin{array}{l}\text { PART } \\
3\end{array}$ & $\begin{array}{l}-- \\
--\end{array}$ \\
\hline 18 & List of variables & -- & -- & character & -- & -- \\
\hline
\end{tabular}


Table 18. File format for general network configuration and parameters (file-identification code 0 used in OPONDS computer program)-Continued

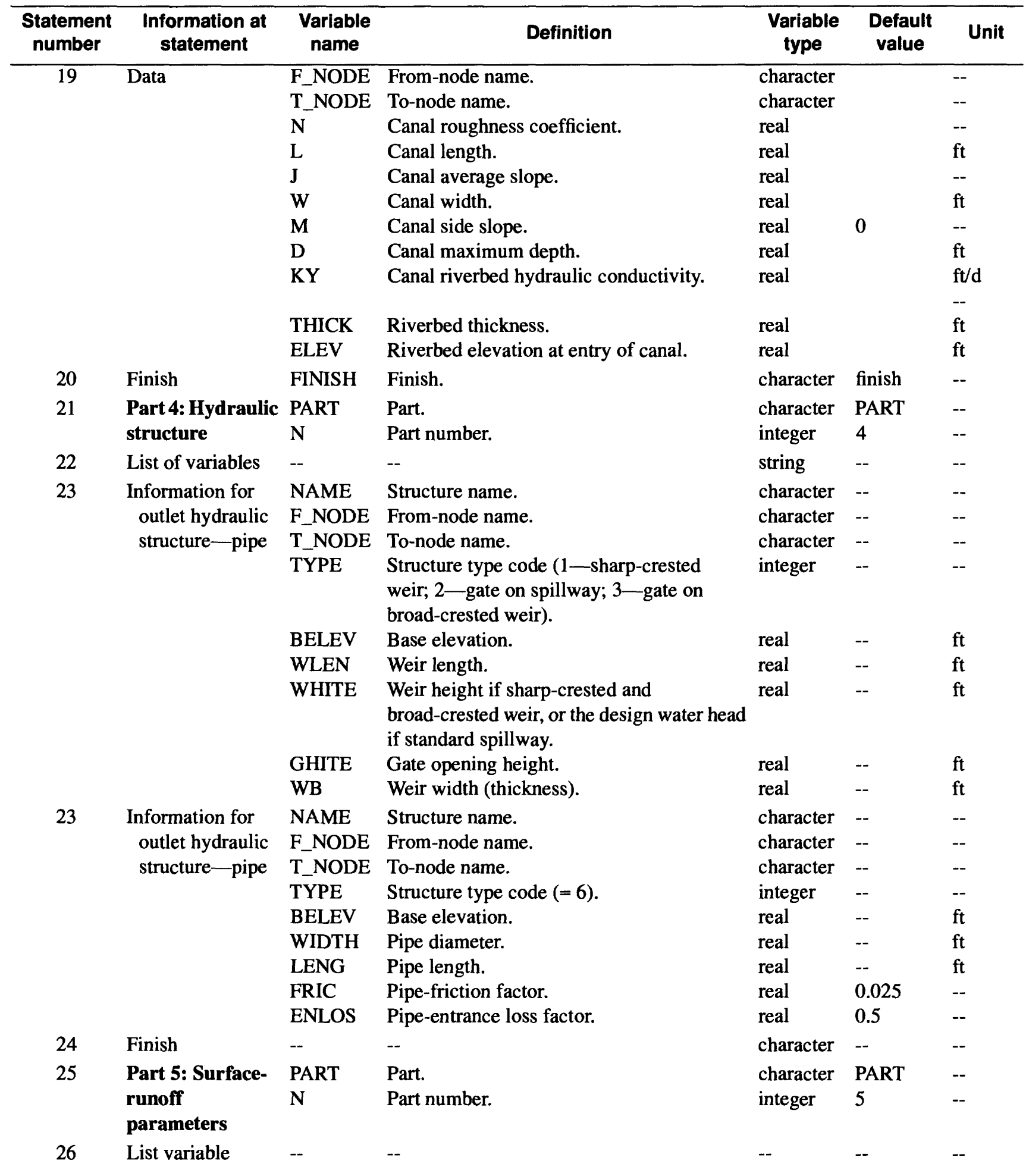


Table 18. File format for general network configuration and parameters (file-identification code 0 used in OPONDS computer program)-Continued

\begin{tabular}{|c|c|c|c|c|c|c|}
\hline $\begin{array}{l}\text { Statement } \\
\text { number }\end{array}$ & $\begin{array}{l}\text { Information at } \\
\text { statement }\end{array}$ & $\begin{array}{l}\text { Variable } \\
\text { name }\end{array}$ & Definition & $\begin{array}{l}\text { Variable } \\
\text { type }\end{array}$ & $\begin{array}{l}\text { Default } \\
\text { value }\end{array}$ & Unit \\
\hline \multirow[t]{6}{*}{27} & Data & NAME & Nodal name. & character & -- & -- \\
\hline & & A5DR0 & Initial total antecedent 5-day rainfall. & real & -- & in. \\
\hline & & A5DRI & $\begin{array}{l}\text { Antecedent 5-day rainfall for dry condi- } \\
\text { tions. }\end{array}$ & real & -- & in. \\
\hline & & A5DRIII & $\begin{array}{l}\text { Antecedent 5-day rainfall for wet condi- } \\
\text { tions. }\end{array}$ & real & -- & in. \\
\hline & & SCSCN & SCS curve number for average condition. & real & -- & -- \\
\hline & & AREA & Drainage area. & real & -- & acres \\
\hline 28 & Finish & -- & -- & -- & -- & -- \\
\hline \multirow[t]{2}{*}{29} & Part 10: & PART & Part. & character & PART & -- \\
\hline & $\begin{array}{l}\text { Seasonal target } \\
\text { water demands }\end{array}$ & $\mathbf{N}$ & Part number. & integer & 10 & -- \\
\hline 30 & Unit & WSUNIT & $\begin{array}{l}\text { Target water-demand unit code (0-acre-ft; } \\
\left.1-\mathrm{ft}^{3} / \mathrm{s} ; 2-\mathrm{ft}^{3} / \mathrm{d}\right)\end{array}$ & integer & 0 & -- \\
\hline \multirow[t]{2}{*}{31} & List of variables & TIME & Time step. & character & -- & -- \\
\hline & & $\begin{array}{l}\text { (NAME } \\
(\mathrm{I}) \\
\mathrm{I}=1, \\
\text { NWSND) }\end{array}$ & $\begin{array}{l}\text { Nodal names. NWSND is the number of } \\
\text { nodes with seasonal target water demands. }\end{array}$ & character & -- & -- \\
\hline \multirow[t]{2}{*}{32} & Target water & TIME & Season. & character & -- & -- \\
\hline & $\begin{array}{l}\text { demands for } \\
\text { each season } \mathrm{N} \text {, } \\
\mathrm{N}=1, \text { NPER }\end{array}$ & $\begin{array}{l}\text { (WSTB } \\
(\mathrm{N}, \mathrm{J}), \mathrm{J}= \\
1, \\
\text { NWSND) }\end{array}$ & Seasonal target water demands. & real & -- & -- \\
\hline 33 & Finish & FINISH & Finish. & character & finish & - \\
\hline \multirow[t]{2}{*}{34} & Part 11: & PART & Part. & character & PART & -- \\
\hline & $\begin{array}{l}\text { Seasonal water- } \\
\text { surface evapora- } \\
\text { tion coefficient }\end{array}$ & $\mathbf{N}$ & Part number. & integer & 11 & -- \\
\hline 35 & Unit & EVUNIT & $\begin{array}{l}\text { Surface-water evaporation coefficient unit } \\
\text { code }(0-\mathrm{mm} / \mathrm{d} ; 1-\mathrm{in} / \mathrm{d} ; 2-\mathrm{ft} / \mathrm{d}) \text {. }\end{array}$ & integer & -- & -- \\
\hline \multirow[t]{2}{*}{36} & List of variables & TIME & Time step. & character & -- & -- \\
\hline & & $\begin{array}{l}\text { (NAME } \\
(\mathrm{I}), \mathrm{I}=1, \\
\mathrm{NEV})\end{array}$ & $\begin{array}{l}\text { Nodal names. NEV is the number of nodes } \\
\text { with surface-water evaporation coefficients. }\end{array}$ & character & -- & -- \\
\hline \multirow[t]{2}{*}{37} & Water-surface & TIME & Season. & char & - & - \\
\hline & $\begin{array}{l}\text { evaporation } \\
\text { coefficients for } \\
\text { each season } \mathrm{N} \\
\mathrm{N}=1, \mathrm{NPER}\end{array}$ & $\begin{array}{l}\text { (EVTB } \\
(\mathrm{N}, J) \\
\mathrm{J}=1, \\
\mathrm{NEV})\end{array}$ & Evaporation coefficients. & real & - & -- \\
\hline 38 & Finish & FINISH & Finish. & character & finish & -- \\
\hline \multirow[t]{2}{*}{39} & Part 12: & PART & Part. & character & PART & -- \\
\hline & $\begin{array}{l}\text { Seasonal flow } \\
\text { boundaries }\end{array}$ & $\mathbf{N}$ & Part number. & integer & 12 & -- \\
\hline 40 & Unit & FBUNIT & $\begin{array}{l}\text { Flow unit code (0-acre-ft; } 1-\mathrm{ft}^{3} / \mathrm{s} \\
\left.2-\mathrm{ft}^{3} / \mathrm{d}\right)\end{array}$ & integer & -- & -- \\
\hline
\end{tabular}


Table 18. File format for general network configuration and parameters (file-identification code 0 used in OPONDS computer program)-Continued

\begin{tabular}{|c|c|c|c|c|c|c|}
\hline $\begin{array}{l}\text { Statement } \\
\text { number }\end{array}$ & $\begin{array}{l}\text { Information at } \\
\text { statement }\end{array}$ & $\begin{array}{l}\text { Variable } \\
\text { name }\end{array}$ & Definition & $\begin{array}{c}\text { Variable } \\
\text { type }\end{array}$ & $\begin{array}{l}\text { Default } \\
\text { value }\end{array}$ & Unit \\
\hline 41 & $\begin{array}{l}\text { List of nodal } \\
\text { names }\end{array}$ & $\begin{array}{l}\text { (NAME } \\
(\mathrm{J}), \mathrm{J}=1 \\
\text { NFBAR) }\end{array}$ & $\begin{array}{l}\text { From-nodal names. NFBAR is the number } \\
\text { of arcs. }\end{array}$ & character & -- & -- \\
\hline 42 & $\begin{array}{l}\text { List of nodal } \\
\text { names }\end{array}$ & $\begin{array}{l}\text { (NAME } \\
(J), J=1 \\
\text { NFBAR) }\end{array}$ & To-nodal names. & character & -- & -- \\
\hline 43 & Zone index & $\begin{array}{l}\text { TIME, } \\
\text { (FBIDX } \\
(\mathrm{J}), \mathrm{J}=1, \\
\text { NFBAR) }\end{array}$ & $\begin{array}{l}\text { Season. } \\
\text { Flow-zone index }(-1, \text { lower boundary of } \\
\text { normal flow zone; }+1 \text {, upper boundary of } \\
\text { normal flow zone, }<-2 \text {, lower extended flow } \\
\text { zone; }>+2 \text {, upper extended flow zone; that } \\
\text { is, } \text { ndex }=\text { zone } \pm) \text {. }\end{array}$ & $\begin{array}{l}\text { character } \\
\text { integer }\end{array}$ & - & - \\
\hline 44 & $\begin{array}{l}\text { Flow boundaries } \\
\text { for each season } \\
N, N=1, N P E R\end{array}$ & $\begin{array}{l}\text { TIME, } \\
\text { (FBTB } \\
(\mathrm{N}, \mathrm{J}), \mathrm{J}= \\
1, \\
\text { NFBAR) }\end{array}$ & $\begin{array}{l}\text { Season. } \\
\text { Seasonal flow boundaries. }\end{array}$ & $\begin{array}{l}\text { character } \\
\text { real }\end{array}$ & $\begin{array}{l}-- \\
--\end{array}$ & -- \\
\hline 45 & Finish & FINISH & Finish. & character & finish & -- \\
\hline 46 & $\begin{array}{l}\text { Part 13: } \\
\text { Seasonal rule } \\
\text { curve }\end{array}$ & $\begin{array}{l}\text { PART } \\
\mathrm{N}\end{array}$ & $\begin{array}{l}\text { Part. } \\
\text { Part number. }\end{array}$ & $\begin{array}{l}\text { character } \\
\text { integer }\end{array}$ & $\begin{array}{l}\text { PART } \\
13\end{array}$ & -- \\
\hline 47 & Unit & RCUNIT & $\begin{array}{l}\text { Rule-curve elevation unit code }(0-\mathrm{ft} ; 1- \\
\text { in.; } 2-\mathrm{mm}) \text {. }\end{array}$ & integer & -- & -- \\
\hline 48 & List of variables & $\begin{array}{l}\text { TIME } \\
\text { (NAME } \\
\text { (I), } \\
\text { I = 1, } \\
\text { NRCND) }\end{array}$ & $\begin{array}{l}\text { Time step. } \\
\text { Pond nodal names. NRCND is the number } \\
\text { of pond nodes with seasonal rule curves. }\end{array}$ & $\begin{array}{l}\text { character } \\
\text { character }\end{array}$ & -- & -- \\
\hline 49 & $\begin{array}{l}\text { Rule curves for } \\
\text { each season } N, N \\
=1, \text { NPER }\end{array}$ & $\begin{array}{l}\mathrm{N} \\
(\mathrm{RCTB} \\
(\mathrm{N}, \mathrm{J}) \\
\mathrm{J}=1, \\
\text { NRCND) }\end{array}$ & $\begin{array}{l}\text { Season. } \\
\text { Rule-curve elevation. }\end{array}$ & $\begin{array}{l}\text { character } \\
\text { real }\end{array}$ & -- & -- \\
\hline 50 & Finish & FINISH & Finish. & character & finish & -- \\
\hline
\end{tabular}




\section{Pond-Zoning File}

The pond-zoning file is used to specify pond-storage zones and bottom hydraulic parameters. Initial storage, rule curve, pond zoning, and penalty coefficients are specified in this file. The bottom hydraulic and geometry data include hydraulic conductivity, average thickness of bottom layer, and bottom elevation. Input instructions and explanations of variables are listed in table 19. The file-identification code is 1 . All data specified in this file can also be included in the general network-configuration and parameter file (table 18).

Table 19. File format for initial pond condition and zoning (file-identification code 1 used in OPONDS computer program)

[ft, feet; acre-ft, acre-feet; ft/d, feet per day; --, not applicable]

\begin{tabular}{|c|c|c|c|c|c|}
\hline $\begin{array}{l}\text { State- } \\
\text { ment } \\
\text { num- } \\
\text { ber }\end{array}$ & $\begin{array}{l}\text { Information at } \\
\text { statement }\end{array}$ & $\begin{array}{c}\text { Variable } \\
\text { name }\end{array}$ & Definition & $\begin{array}{c}\text { Variable } \\
\text { type }\end{array}$ & Unit \\
\hline $1-5$ & Title lines & & Specify data information about source, etc. & & \\
\hline 6 & $\begin{array}{l}\text { Pond zoning and } \\
\text { bottom hydrau- } \\
\text { lic parameter } \\
\text { for each pond }\end{array}$ & $\begin{array}{l}\text { NAME } \\
\text { UNITCD } \\
\text { INST } \\
\text { BOT } \\
\text { KY } \\
\text { B } \\
\text { RC } \\
(\text { Z(I) } \\
\text { COST(I) } \\
\text { I }=1 \\
\text { NZONE) }\end{array}$ & $\begin{array}{l}\text { Pond node name. } \\
\text { Stage unit code }(0-\mathrm{ft}, 1 \text {-acre-ft). } \\
\text { Pond initial elevation or storage. } \\
\text { Bottom elevation. } \\
\text { Bottom layer hydraulic conductivity. } \\
\text { Bottom layer thickness. } \\
\text { Rule-curve stage. } \\
\text { Zone stage (see note } 1) \text {. } \\
\text { Penalty coefficients (see note } 1) \text {. NZONE is } \\
\text { the number of storage zones of a pond. }\end{array}$ & $\begin{array}{l}\text { character } \\
\text { integer } \\
\text { real } \\
\text { real } \\
\text { real } \\
\text { real } \\
\text { real } \\
\text { real } \\
\text { integer }\end{array}$ & $\begin{array}{c}-- \\
-- \\
-- \\
\mathrm{ft} \\
\mathrm{ft} / \mathrm{d} \\
\mathrm{ft} \\
-- \\
-- \\
--\end{array}$ \\
\hline
\end{tabular}

Note:

1. If there is more than one zone, $\mathrm{Z}$ and COST must be specified for each zone. Zone boundaries (that is, elevations) or corresponding storage are specified at the beginning of the zones next to the rule curve. 


\section{Canal-Geometry and Riverbed Hydraulic Parameter File}

The canal-geometry and riverbed hydraulic parameter file is used for specifying canal cross-section data, riverbed hydraulic parameters, canal lengths, and canal-entry bottom elevations. These data are used mainly in canal routing for determining canal seepage and surface-water evaporation. These data are optional. Input instructions and explanations of variables are listed in table 21 . The file-identification code is 3 . All data specified in this file also can be included in the general network-configuration and parameter file (table 18).

Tabie 21. File format for canal geometry and riverbed hydraulic parameters (file-identification code 3 used in OPONDS computer program)

[ft, feet; ft/d, feet per day; --, not applicable]

\begin{tabular}{clllcc}
\hline $\begin{array}{c}\text { State- } \\
\text { ment } \\
\text { num- } \\
\text { ber }\end{array}$ & $\begin{array}{c}\text { information at } \\
\text { statement }\end{array}$ & Variabie & \multicolumn{1}{c}{ Definition } & $\begin{array}{c}\text { Variabie } \\
\text { type }\end{array}$ & Unit \\
\hline $1-5$ & Title lines & -- & -- & -- & -- \\
6 & Canal geometry & F_NODE & From-node name. & character & -- \\
& data & T_NODE & To-node name. & character & -- \\
& N & Canal roughness coefficient. & real & - \\
& L & Canal length. & real & $\mathrm{ft}$ \\
& J & Canal average slope. & real & - \\
& W & Canal bottom width. & real & $\mathrm{ft}$ \\
& M & Canal side slope. & real & -- \\
& D & Canal maximum depth. & real & $\mathrm{ft}$ \\
& KY & Canal riverbed hydraulic conductivity. & real & $\mathrm{ft} / \mathrm{d}$ \\
& THICK & Riverbed thickness. & real & $\mathrm{ft}$ \\
& ELEV & Riverbed elevation at entry. & real & $\mathrm{ft}$ \\
\hline
\end{tabular}




\section{Outlet Hydraulic-Structure Parameter File}

Outlet hydraulic structures included in the OPONDS program are rectangular sharp-crested weirs, vertical sluice gates on broad-crested weirs, vertical flat gates on spillways, and pipes. Flow through gated weirs and sharp-crested weirs is assumed to be controllable by adjusting gate opening heights or sharp-crested weir heights. The data needed and input instructions and explanations of variables are listed in table 22. The file-identification code is 4 . All data specified in this file also can be included in the general network-configuration and parameter file (table 18).

Table 22. File format for outlet hydraulic-structure parameters (file-identification code 4 used in OPONDS computer program)

[ft, feet; --, not applicable]

\begin{tabular}{|c|c|c|c|c|c|c|}
\hline $\begin{array}{l}\text { State- } \\
\text { ment } \\
\text { num- } \\
\text { ber }\end{array}$ & $\begin{array}{l}\text { Information at } \\
\text { statement }\end{array}$ & Variable & Definition & $\begin{array}{c}\text { Variable } \\
\text { type }\end{array}$ & $\begin{array}{c}\text { Default } \\
\text { value }\end{array}$ & Unit \\
\hline $1-5$ & Title lines & -- & -- & -- & -- & -- \\
\hline \multirow[t]{18}{*}{6} & \multirow{9}{*}{$\begin{array}{l}\text { Information for } \\
\text { each weir }\end{array}$} & NAME & Structure name, & character & -- & -- \\
\hline & & F_NODE & Nodal name (see note 4 ). & character & -- & -- \\
\hline & & T_NODE & Downstream nodal name (see note 4). & character & -- & -- \\
\hline & & TYPE & Structure type code (see note 1 ). & integer & -- & -- \\
\hline & & BELEV & Base elevation (see note 2 ). & real & -- & $\mathrm{ft}$ \\
\hline & & WLEN & Weir length. & real & -- & $\mathrm{ft}$ \\
\hline & & WHITE & $\begin{array}{l}\text { Weir height if sharp-crested and } \\
\text { broad-crested weir, or the design water } \\
\text { head if standard spillway. }\end{array}$ & real & -- & $\mathrm{ft}$ \\
\hline & & GHITE & Gate opening height. & real & -- & $\mathrm{ft}$ \\
\hline & & WB & Weir width (thickness). & real & -- & $\mathrm{ft}$ \\
\hline & \multirow{9}{*}{$\begin{array}{l}\text { Information for } \\
\text { each outlet } \\
\text { pipe }\end{array}$} & NAME & Structure name. & character & -- & -- \\
\hline & & F_NODE & Nodal name (see note 4 ). & character & -- & -- \\
\hline & & T_NODE & Downstream nodal name (see note 4 ). & character & -- & -- \\
\hline & & TYPE & Structure type code (see note 1 ). & integer & -- & -- \\
\hline & & BELEV & Base elevation (see note 2 ). & real & -- & $\mathrm{ft}$ \\
\hline & & WIDTH & Pipe diameter. & real & -- & $\mathrm{ft}$ \\
\hline & & LENG & Pipe length (see note 3 ). & real & -- & $\mathrm{ft}$ \\
\hline & & FRIC & Pipe-friction factor. & real & 0.025 & -- \\
\hline & & ENLOS & Pipe-entrance loss factor. & real & 0.5 & -- \\
\hline
\end{tabular}

Notes:

1. Hydraulic-structure type code:

1 -Rectangular sharp-crested weir $(0<\mathrm{H} / \mathrm{P}<5)$.

2-Vertical flat gate on spillway. Gate edge is facing downstream.

3-Vertical sluice gate on broad-crested weir.

6-Pipe.

2. Base elevation: (1) bottom of a weir if sharp-crested weir, (2) top of a weir if spillway or broad-crested weir, and (3) center of a pipe at entry if pipe.

3. If sharp-crested weir height is less than zero $(<0)$, the weir height is adjustable, and the absolute value is the maximum height allowed.

4. There is only one flow zone downstream from the structure. No extended flow zones are allowed. 


\section{Surface-Runoff Parameter File}

Surface runoff is calculated using the SCS curve-number method (Soil Conservation Service, 1985). Data needed are drainage area, curve number for average condition, initial antecedent 5-day rainfall, and criteria for wet/dry conditions. Input instructions and explanations of variables are listed in table 23 . The file-identification code is 5 . All data specified in this file also can be included in the general network-configuration and parameter file (table 18).

Table 23. File format for surface-runoff parameters (file-identification code 5 used in OPONDS computer program)

[in., inches; --, not applicable]

\begin{tabular}{|c|c|c|c|c|c|c|}
\hline $\begin{array}{c}\text { State- } \\
\text { ment } \\
\text { num- } \\
\text { ber }\end{array}$ & $\begin{array}{l}\text { Information at } \\
\text { statement }\end{array}$ & Variable & Definition & $\begin{array}{c}\text { Variable } \\
\text { type }\end{array}$ & $\begin{array}{l}\text { Default } \\
\text { value }\end{array}$ & Unit \\
\hline $1-5$ & Title lines & -- & -- & - & -- & -- \\
\hline \multirow[t]{6}{*}{6} & Data & NAME & Nodal name. & character & -- & -- \\
\hline & & A5DR0 & Initial antecedent 5-day rainfall. & real & -- & in. \\
\hline & & A5DRI & $\begin{array}{l}\text { Antecedent 5-day rainfall for dry conditions } \\
\text { (I) (see note } 1 \text { ). }\end{array}$ & real & 0.5 & in. \\
\hline & & A5DRIII & $\begin{array}{l}\text { Antecedent } 5 \text {-day rainfall for wet condi- } \\
\text { tions (III) (see note } 2 \text { ). }\end{array}$ & real & 1.1 & in. \\
\hline & & SCSCN & $\begin{array}{l}\text { SCS curve number for average conditions } \\
\text { (II). }\end{array}$ & real & -- & -- \\
\hline & & AREA & Drainage area. & real & -- & acres \\
\hline
\end{tabular}

1. The suggested values are less than $0.5 \mathrm{in}$. for dormant season and less than $1.4 \mathrm{in}$. for growing season (Soil Conservation Service, 1985; McCuen, 1989).

2. The suggested values are greater than $1.1 \mathrm{in.}$ for dormant season and greater than $2.1 \mathrm{in}$. for growing season (Soil Conservation Service, 1985; McCuen, 1989).

\section{Pond Elevation-Volume-Area Relation File}

If there is any pond operation involved, the pond elevation-volume-area relation file is used. The relations among water-surface elevation, volume, and water-surface area of ponds can be expressed either in tabular form or in the regression equations for the Quivira National Wildlife Refuge (tables 24 and 25). The file-identification code is 9.

Table 24. File format for relations among water-surface elevation $(Z)$, volume $(V)$, and water-surface area $(A)$ of ponds (file-identification code 9 used in OPONDS computer program)

[ft; feet; acre-ft, acre-feet; --, not applicable]

\begin{tabular}{|c|c|c|c|c|c|}
\hline $\begin{array}{c}\text { State- } \\
\text { ment } \\
\text { num- } \\
\text { ber }\end{array}$ & $\begin{array}{l}\text { Information at } \\
\text { statement }\end{array}$ & Variable & Definition & $\begin{array}{c}\text { Variable } \\
\text { type }\end{array}$ & Unit \\
\hline $1-5$ & Title lines & -- & -- & -- & -- \\
\hline 6 & Data source & ZVAMTH & Data source index for $Z-V-A$ data $(=0)$ & integer & -- \\
\hline 7 & Pond name & NAME & Pond nodal name. & character & -- \\
\hline
\end{tabular}


Table 24. File format for relations among water-surface elevation $(Z)$, volume $(V)$, and water-surface area $(A)$ of ponds (file-identification code 9 used in OPONDS computer program)-Continued

\begin{tabular}{cllllll}
\hline $\begin{array}{c}\text { State- } \\
\text { ment } \\
\text { num- } \\
\text { ber }\end{array}$ & $\begin{array}{c}\text { Information at } \\
\text { statement }\end{array}$ & Variable & \multicolumn{1}{c}{ Definition } & & $\begin{array}{c}\text { Variable } \\
\text { type }\end{array}$ & Unit \\
\hline 8 & $\begin{array}{l}\text { Pond character- } \\
\text { istic curves } \\
\text { among eleva- } \\
\text { tion, capacity, } \\
\text { and area }\end{array}$ & CAE & AREA & $\begin{array}{l}\text { Water-surface elevation. } \\
\text { Water volume of a pond at the current ele- } \\
\text { vation. } \\
\text { Water-surface area. }\end{array}$ & $\begin{array}{c}\text { real } \\
\text { real }\end{array}$ & $\begin{array}{c}\mathrm{ft} \\
\text { acre-ft }\end{array}$ \\
9 & $\begin{array}{l}\text { Empty line } \\
10\end{array}$ & Finish & FINISH & Finish reading pond table. & real & acre \\
\hline
\end{tabular}

Table 25. File format for regression relations of water-surface elevation $(Z)$, volume $(V)$, and water-surface area $(A)$ of ponds (file-identification code 9 used in OPONDS computer program)

[ft, feet; --, not applicable]

\begin{tabular}{|c|c|c|c|c|c|}
\hline $\begin{array}{c}\text { State- } \\
\text { ment } \\
\text { num- } \\
\text { ber }\end{array}$ & $\begin{array}{l}\text { Information at } \\
\text { statement }\end{array}$ & Variable & Definition & $\begin{array}{l}\text { Variable } \\
\text { type }\end{array}$ & Unit \\
\hline $1-5$ & Title lines & -- & -- & -- & -- \\
\hline 6 & Data source & ZVAMTH & Data source index for $Z-V-A$ data $(=1)$ & integer & -- \\
\hline 7 & Pond name & NAME & Pond nodal name. & character & -- \\
\hline 8 & $\begin{array}{l}\text { Base and coeffi- } \\
\text { cients for each } \\
\text { regression } \\
\text { equation }\end{array}$ & $\begin{array}{l}\text { N } \\
\text { ZB } \\
\text { A1 } \\
\text { A2 } \\
\text { A3 }\end{array}$ & $\begin{array}{l}\text { Equation sequential number. } \\
\text { Zonal elevation base. } \\
\text { Coefficient } \mathrm{A} 1 \text {. } \\
\text { Coefficient } \mathrm{A} 2 \text {. } \\
\text { Coefficient } \mathrm{A} 3 \text {. }\end{array}$ & $\begin{array}{l}\text { integer } \\
\text { real } \\
\text { real } \\
\text { real } \\
\text { real }\end{array}$ & $\begin{array}{l}-- \\
\mathrm{ft} \\
-- \\
--\end{array}$ \\
\hline 9 & Empty line & -- & Move to next pond node. & -- & -- \\
\hline 10 & Finish & FINISH & $\begin{array}{l}\text { Finish reading coefficients of regression } \\
\text { equations. }\end{array}$ & character & -- \\
\hline
\end{tabular}

\section{Seasonal Target Water-Demand File}

Target water demand in the OPONDS program means that water will be withdrawn from a node; that is, water will be taken out of the canal and control-pond system. Input instructions and explanations of variables are listed in table 26. The file-identification code is 10 . All data specified in this file also can be included in the general network-configuration and parameter file (table 18). 
Table 26. File format for seasonal target water demands (file-identification code 10 used in OPONDS computer program)

[acre-ft, acre-feet; $\mathrm{ft}^{3} / \mathrm{s}$, cubic feet per second; $\mathrm{ft}^{3} / \mathrm{d}$, cubic feet per day; --, not applicable]

\begin{tabular}{|c|c|c|c|c|}
\hline $\begin{array}{l}\text { State- } \\
\text { ment } \\
\text { num- } \\
\text { ber }\end{array}$ & $\begin{array}{l}\text { Information at } \\
\text { statement }\end{array}$ & Variable & Definition & $\begin{array}{c}\text { Variable } \\
\text { type }\end{array}$ \\
\hline $1-5$ & Title lines & -- & -- & - \\
\hline 6 & $\begin{array}{l}\text { Water-demand } \\
\text { unit }\end{array}$ & WSUNIT & $\begin{array}{l}\text { Water-demand unit code (0-acre-ft, } 1- \\
\left.\mathrm{ft}^{3} / \mathrm{s}, 2-\mathrm{ft}^{3} / \mathrm{d}\right)\end{array}$ & integer \\
\hline 7 & $\begin{array}{l}\text { List of nodal } \\
\text { names }\end{array}$ & $\begin{array}{l}\text { TIME } \\
\text { NAME(I), } \\
I=1 \\
\text { NWSND }\end{array}$ & $\begin{array}{l}\text { Time step. } \\
\text { Nodal names (see note 1). NWSND is the } \\
\text { number of nodes with water demands. }\end{array}$ & $\begin{array}{l}\text { character } \\
\text { character }\end{array}$ \\
\hline 8 & $\begin{array}{l}\text { Target water } \\
\text { demands for } \\
\text { each season } \\
\text { N, N = 1, } \\
\text { NPER }\end{array}$ & $\begin{array}{l}\text { TIME } \\
\text { (WSTB } \\
\text { (N,J), J = 1, } \\
\text { NWSND) }\end{array}$ & $\begin{array}{l}\text { Season. } \\
\text { Seasonal target water demands. }\end{array}$ & $\begin{array}{c}\text { character } \\
\text { real }\end{array}$ \\
\hline
\end{tabular}

Note:

1. Use the nodal name DEFAULT for nodes with the same target water demands. The DEFAULT node must follow the other specified nodes (that is, in last column).

\section{Seasonal Water-Surface Evaporation File}

Seasonal water-surface evaporation from a pond node or canal segment is calculated using evaporation coefficients and water-surface area. Input instructions and explanations of variables for evaporation coefficients are listed in table 27. The file-identification code is 11 . All data specified in this file also can be included in the general network-configuration and parameter file (table 18).

Table 27. File format for seasonal water-surface evaporation coefficients (file-identification code 11 used in OPONDS computer program)

[mm/d; millimeters per day; in/d, inches per day; ft/d, feet per day; --, not applicable]

\begin{tabular}{|c|c|c|c|c|}
\hline $\begin{array}{l}\text { State- } \\
\text { ment } \\
\text { num- } \\
\text { ber }\end{array}$ & $\begin{array}{l}\text { Information at } \\
\text { statement }\end{array}$ & Variable & Definition & $\begin{array}{l}\text { Variable } \\
\text { type }\end{array}$ \\
\hline $1-5$ & Title lines & -- & -- & - \\
\hline 6 & Unit & EVUNIT & $\begin{array}{l}\text { Water-surface evaporation coefficient }(0- \\
\mathrm{mm} / \mathrm{d} ; 1-\mathrm{in} / \mathrm{d} ; 2-\mathrm{ft} / \mathrm{d}) .\end{array}$ & integer \\
\hline 7 & $\begin{array}{l}\text { List of nodal } \\
\text { names }\end{array}$ & $\begin{array}{l}\text { TIME } \\
\text { (NAME(J), } \\
\mathrm{J}=1, \mathrm{NEV})\end{array}$ & $\begin{array}{l}\text { Time. } \\
\text { Nodal names (see note 1). NEV is the num- } \\
\text { ber of nodes with evaporation coefficients. }\end{array}$ & $\begin{array}{l}\text { character } \\
\text { charac- } \\
\text { ter }\end{array}$ \\
\hline
\end{tabular}


Tabie 27. File format for seasonal water-surface evaporation coefficients (file-identification code 11 used in OPONDS computer program)-Continued

\begin{tabular}{|c|c|c|c|c|}
\hline $\begin{array}{l}\text { State- } \\
\text { ment } \\
\text { num- } \\
\text { ber }\end{array}$ & $\begin{array}{l}\text { information at } \\
\text { statement }\end{array}$ & Variabie & Definition & $\begin{array}{l}\text { Variabie } \\
\text { type }\end{array}$ \\
\hline 8 & $\begin{array}{l}\text { Evaporation } \\
\text { coefficients } \\
\text { for each sea- } \\
\text { son } \mathrm{N}, \mathrm{N}=1 \text {, } \\
\text { NPER }\end{array}$ & $\begin{array}{l}\text { TIME } \\
(\text { EVTB } \\
(\mathrm{N}, \mathrm{J}), \mathrm{J}=1 \text {, } \\
\text { NEV) }\end{array}$ & $\begin{array}{l}\text { Season index. } \\
\text { Evaporation coefficients. }\end{array}$ & $\begin{array}{l}\text { character } \\
\text { real }\end{array}$ \\
\hline
\end{tabular}

\section{Seasonal Flow-Boundary File}

The flow requirements in canals may be different for different seasons. In the linear network setting, these flow requirements are represented by flow boundaries in the associated arcs. Input instructions and explanations of variables for seasonal flow boundaries are listed in table 28. The file-identification code is 12 . All data specified in this file can also be included in the general network-configuration and parameter file (table 18).

Tabie 28. File format for seasonal flow boundaries (file-identification code 12 used in OPONDS computer program)

\begin{tabular}{|c|c|c|c|c|}
\hline $\begin{array}{l}\text { State- } \\
\text { ment } \\
\text { num- } \\
\text { ber }\end{array}$ & $\begin{array}{l}\text { information at } \\
\text { statement }\end{array}$ & Variabie & Definition & $\begin{array}{l}\text { Variabie } \\
\text { type }\end{array}$ \\
\hline $1-5$ & Title lines & & -. & -- \\
\hline 6 & Unit & FBUNIT & $\begin{array}{l}\text { Flow unit code (0-acre-ft; } 1-\mathrm{ft}^{3} / \mathrm{s} ; 2- \\
\left.\mathrm{ft}^{3} / \mathrm{d}\right) \text {. }\end{array}$ & integer \\
\hline 7 & $\begin{array}{l}\text { List of upstream } \\
\text { nodal names }\end{array}$ & $\begin{array}{l}(\mathrm{NAME}(\mathrm{J}), \mathrm{J} \\
=1 \\
\text { NFBAR) }\end{array}$ & $\begin{array}{l}\text { From-node names of arcs. NFBAR is the } \\
\text { number of arcs with seasonal flow bound- } \\
\text { aries. }\end{array}$ & character \\
\hline 8 & $\begin{array}{l}\text { List of down- } \\
\text { stream nodal } \\
\text { names }\end{array}$ & $\begin{array}{l}(\mathrm{NAME}(\mathrm{J}), \mathrm{J} \\
=1 \\
\text { NFBAR) }\end{array}$ & To-node names of arcs. & character \\
\hline 9 & Zone index & $\begin{array}{l}\text { TIME, } \\
\text { (FBIDX(J), } \\
\mathrm{J}=1 \\
\text { NFBAR) }\end{array}$ & $\begin{array}{l}\text { Season. } \\
\text { Flow-zone index }(-1, \text { lower boundary of } \\
\text { normal flow zone; }+1 \text {, upper boundary of } \\
\text { normal flow zone; }<-2 \text {, lower extended flow } \\
\text { zone; }>+2 \text {, upper extended flow zone; that } \\
\text { is, } \text { ndex }=\text { zone } \pm) \text {. }\end{array}$ & $\begin{array}{l}\text { character } \\
\text { integer }\end{array}$ \\
\hline 10 & $\begin{array}{l}\text { Flow boundaries } \\
\text { for each season } \\
\mathrm{N}, \mathrm{N}=1 \\
\mathrm{NPER}\end{array}$ & $\begin{array}{l}\text { TIME, } \\
\text { (FBTB } \\
(\mathrm{N}, \mathrm{J}), \mathrm{J}=1, \\
\text { NFBAR), N } \\
=1, \text { NPER }\end{array}$ & $\begin{array}{l}\text { Season. } \\
\text { Seasonal flow boundary (see note } 1 \text { ). }\end{array}$ & $\begin{array}{l}\text { character } \\
\text { real }\end{array}$ \\
\hline
\end{tabular}

Note:

1. For lower or upper extended flow zones, flow boundaries are equal to flow-zone capacities. 


\section{Seasonal Pond Rule-Curve File}

Management water levels in a pond may change seasonally. The seasonal water levels are represented by the different rule curves in the linear-network flow model. Input instructions and explanations of variables for seasonal rule curves are listed in table 29 . The file-identification code is 13 . All data specified in this file also can be included in the general network-configuration and parameter file (table 18).

Table 29. File format for seasonal pond rule curves (file-identification code 13 used in OPONDS computer program)

[ft, feet; in., inches; mm, millimeters; --, not applicable]

\begin{tabular}{|c|c|c|c|c|}
\hline $\begin{array}{l}\text { State- } \\
\text { ment } \\
\text { num- } \\
\text { ber }\end{array}$ & $\begin{array}{l}\text { Information at } \\
\text { statement }\end{array}$ & Variable & Definition & $\begin{array}{l}\text { Variable } \\
\text { type }\end{array}$ \\
\hline $1-5$ & Title lines & - & - & -- \\
\hline 6 & Unit & RCUNIT & $\begin{array}{l}\text { Rule-curve elevation unit code }(0-\mathrm{ft} \text {; } \\
1-\text { in.; } 2-\mathrm{mm}) \text {. }\end{array}$ & integer \\
\hline 7 & $\begin{array}{l}\text { List of nodal } \\
\text { names }\end{array}$ & $\begin{array}{l}\text { TIME } \\
\text { (NAME(J), } \\
\text { J =1, } \\
\text { NRCND) }\end{array}$ & $\begin{array}{l}\text { Time. } \\
\text { Pond nodal names (see note } 1 \text { ). NRCND is } \\
\text { the number of pond nodes with seasonal } \\
\text { rule curves. }\end{array}$ & $\begin{array}{l}\text { character } \\
\text { character }\end{array}$ \\
\hline 8 & $\begin{array}{l}\text { Rule curves for } \\
\text { each season } N \text {, } \\
N=1 \text {, NPER }\end{array}$ & $\begin{array}{l}\text { TIME } \\
\text { (RCTB } \\
\text { (N,J), J=1, } \\
\text { NRCND) }\end{array}$ & $\begin{array}{l}\text { Season. } \\
\text { Rule-curve elevations. }\end{array}$ & $\begin{array}{c}\text { character } \\
\text { real }\end{array}$ \\
\hline
\end{tabular}

Note:

1. Use the nodal name DEFAULT for pond nodes with the same rule curves. The DEFAULT node must follow the other specified nodes (that is, in last column).

\section{Local Net Incremental Inflow File}

The local net incremental inflow file is used to specify nodes and their local net inflows. Local net incremental inflow is the water locally attributed to a node. Input instructions and explanations of variables for local net inflows are listed in table 30 . The file-identification code is 16.

Table 30. File format for local net incremental inflows (file-identification code 16 used in OPONDS computer program)

[acre-ft, acre-feet; $\mathrm{ft}^{3} / \mathrm{s}$, cubic feet per second; $\mathrm{ft}^{3} / \mathrm{d}$, cubic feet per day; --, not applicable]

\begin{tabular}{|c|c|c|c|c|}
\hline $\begin{array}{l}\text { State- } \\
\text { ment } \\
\text { num- } \\
\text { ber }\end{array}$ & $\begin{array}{l}\text { Information at } \\
\text { statement }\end{array}$ & Variable & Definition & $\begin{array}{c}\text { Variable } \\
\text { type }\end{array}$ \\
\hline $1-5$ & Title lines & -- & -- & -- \\
\hline 6 & Flow unit & IFWCD & $\begin{array}{l}\text { Flow unit code (0-acre-ft; } 1-\mathrm{ft}^{3} / \mathrm{s} \text {; } \\
\left.2-\mathrm{ft}^{3} / \mathrm{d}\right) \text {. }\end{array}$ & integer \\
\hline 7 & $\begin{array}{l}\text { List of nodal } \\
\text { names }\end{array}$ & $\begin{array}{l}\text { TIME } \\
\text { (NAME(J), } \\
\mathrm{J}=1 \\
\text { NIFW) }\end{array}$ & $\begin{array}{l}\text { Time. } \\
\text { Nodal names (see note 1). NIFW is the } \\
\text { number of nodes with net incremental } \\
\text { inflows. }\end{array}$ & $\begin{array}{l}\text { character } \\
\text { character }\end{array}$ \\
\hline
\end{tabular}


Table 30. File format for local net incremental inflows (file-identification code 16 used in OPONDS computer program)-Continued

\begin{tabular}{ccccc}
\hline $\begin{array}{c}\text { State- } \\
\text { ment } \\
\text { num- } \\
\text { ber }\end{array}$ & $\begin{array}{c}\text { Information at } \\
\text { statement }\end{array}$ & \multicolumn{1}{c}{ Variable } & Definition & $\begin{array}{c}\text { Variable } \\
\text { type }\end{array}$ \\
\hline 8 & $\begin{array}{c}\text { Net inflows to } \\
\text { node for each } \\
\text { time period }\end{array}$ & $\begin{array}{l}\text { TIME } \\
\text { QIN(I), I }=\end{array}$ & Time. Net inflow to nodes (see note 2). & $\begin{array}{c}\text { character } \\
\text { real }\end{array}$ \\
\hline
\end{tabular}

Notes:

1. Use the nodal name DEFAULT for nodes with the same net inflows. The DEFAULT node must follow the other specified nodes (that is, in last column).

2. Net inflow to a node can be either a positive or a negative value.

\section{Precipitation File}

The precipitation file is used to assign precipitation data to nodes. The precipitation data are used to calculate surface runoff to nodes. Input instructions and explanations of variables for precipitation data are listed in table 31. The file-identification code is 17 .

Tabie 31. File format for precipitation data (file-identification code 17 used in OPONDS computer program)

[ft, feet; in., inches; mm, millimeters; acre-ft/d, acre-feet per day; $\mathrm{ft}^{3} / \mathrm{s}$, cubic feet per second; $\mathrm{ft}^{3} / \mathrm{d}$, cubic feet per day; --, not applicable]

\begin{tabular}{|c|c|c|c|c|}
\hline $\begin{array}{l}\text { State- } \\
\text { ment } \\
\text { num- } \\
\text { ber }\end{array}$ & $\begin{array}{l}\text { Information at } \\
\text { statement }\end{array}$ & Variable & Definition & $\begin{array}{l}\text { Variable } \\
\text { type }\end{array}$ \\
\hline $1-5$ & Title lines & -- & -- & -- \\
\hline 6 & Data unit & $\begin{array}{l}\text { RNUNIT } \\
\text { RNTYPE }\end{array}$ & $\begin{array}{l}\text { Data unit code (if mtype }=1,0-\mathrm{ft}, 1- \\
\text { in., } 2-\mathrm{mm} \text {; if rntype }=2,0-\text { acre-ft/d, } \\
1-\mathrm{ft}^{3} / \mathrm{s}, 2-\mathrm{ft}^{3} / \mathrm{d} \text { ). } \\
\text { Date type index (1-depth; 2-flux). }\end{array}$ & $\begin{array}{l}\text { integer } \\
\text { integer }\end{array}$ \\
\hline 7 & $\begin{array}{l}\text { List of nodal } \\
\text { names }\end{array}$ & $\begin{array}{l}\text { TIME } \\
\text { (NAME(J), } \\
\text { J = } 1 \text {, } \\
\text { NRAIN) }\end{array}$ & $\begin{array}{l}\text { Time. } \\
\text { Nodal names (see note 1). NRAIN is the } \\
\text { number of nodes with precipitation. }\end{array}$ & $\begin{array}{l}\text { character } \\
\text { character }\end{array}$ \\
\hline 8 & $\begin{array}{l}\text { Precipitation } \\
\text { data for each } \\
\text { time period }\end{array}$ & $\begin{array}{l}\text { TIME } \\
\text { RAIN(I), } \\
I=1 \\
\text { NRAIN }\end{array}$ & $\begin{array}{l}\text { Time. } \\
\text { Precipitation depth or flux rate to nodes. }\end{array}$ & $\begin{array}{l}\text { character } \\
\text { real }\end{array}$ \\
\hline
\end{tabular}

Note:

1. Use the nodal name DEFAULT for nodes with the same amount of precipitation. The DEFAULT node must follow the other specified nodes (that is, in last column). 


\section{Time-Dependent, Water-Surface Evaporation File}

In general, water-surface evaporation coefficients change with time. Even for the same season and the same place, the evaporation coefficients may be significantly different for different years. This file is designed to input time-dependent, water-surface evaporation coefficients for selected nodes. Input instructions and explanations of variables are listed in table 32. The file-identification code is 18 .

Tabie 32. File format for time-dependent, water-surface evaporation coefficients (file-identification code 18 used in OPONDS computer program)

[mm/d; millimeters per day; in/d, inches per day; ft/d, feet per day; --, not applicable]

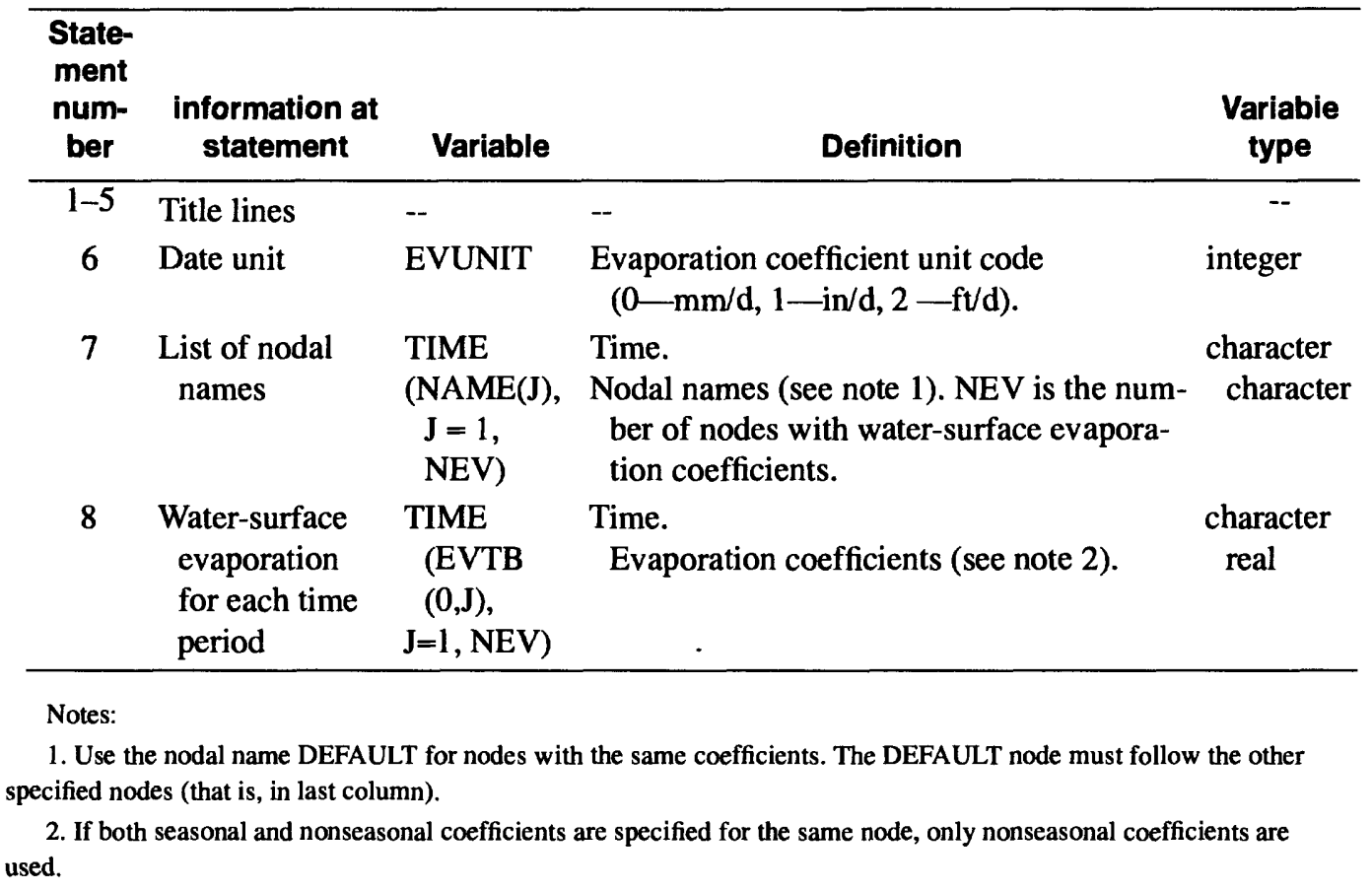

\section{Time-Dependent, Target Water-Demand File}

The time-dependent, target water-demand file is used to input target water demands for selected nodes for which water withdrawals change with time. Input instructions and explanations of variables are listed in table 33. The file-identification code is 19 .

Tabie 33. File format for time-dependent, target water demand (file-identification code 19 used in OPONDS computer program)

[acre-ft, acre-feet; $\mathrm{ft}^{3} / \mathrm{s}$, cubic feet per second; $\mathrm{ft}^{3} / \mathrm{d}$, cubic feet per day; --, not applicable]

\begin{tabular}{cllll}
\hline $\begin{array}{c}\text { State- } \\
\text { ment } \\
\text { num- } \\
\text { ber }\end{array}$ & $\begin{array}{c}\text { information at } \\
\text { statement }\end{array}$ & Variabie & \multicolumn{1}{c}{ Definition } & $\begin{array}{c}\text { Variable } \\
\text { type }\end{array}$ \\
\hline $1-5$ & Title lines & -- & -- & -- \\
6 & $\begin{array}{c}\text { Units of water } \\
\text { demand }\end{array}$ & WSUNIT & $\begin{array}{l}\text { Water-demand unit code }(0-\text { acre-ft; } \\
\left.1-\mathrm{ft}^{3} / \mathrm{s} ; 2-\mathrm{ft}^{3} / \mathrm{d}\right) .\end{array}$ & integer \\
& & &
\end{tabular}


Table 33. File format for time-dependent, target water demand (file-identification code 19 used in OPONDS computer program)-Continued

\begin{tabular}{|c|c|c|c|c|}
\hline $\begin{array}{l}\text { State- } \\
\text { ment } \\
\text { num- } \\
\text { ber }\end{array}$ & $\begin{array}{l}\text { Information at } \\
\text { statement }\end{array}$ & Variable & Definition & $\begin{array}{c}\text { Variable } \\
\text { type }\end{array}$ \\
\hline 7 & $\begin{array}{l}\text { List of nodal } \\
\text { names }\end{array}$ & $\begin{array}{l}\text { TIME } \\
\text { NAME(I), } \\
I=1 \\
\text { NWSND }\end{array}$ & $\begin{array}{l}\text { Time step. } \\
\text { Nodal names (see note 1). NWSND is the } \\
\text { number of nodes with target water } \\
\text { demands. }\end{array}$ & $\begin{array}{l}\text { character } \\
\text { character }\end{array}$ \\
\hline 8 & $\begin{array}{l}\text { Target water } \\
\text { demand for } \\
\text { each time } \\
\text { period }\end{array}$ & $\begin{array}{l}\text { TIME } \\
\text { (WSTB } \\
(0, \mathrm{~J}), \mathrm{J}=1 \text {, } \\
\text { NWSND) }\end{array}$ & $\begin{array}{l}\text { Time. } \\
\text { Target water demands (see note } 2 \text { ). }\end{array}$ & $\begin{array}{l}\text { character } \\
\text { real }\end{array}$ \\
\hline
\end{tabular}

Notes:

1. Use the nodal name DEFAULT for nodes with the same target water demands. The DEFAULT node must follow the other specified nodes (that is, in last column).

2. If both seasonal and nonseasonal values are specified for the same node, only nonseasonal values are used.

\section{Time-Dependent, Pond Rule-Curve File}

The target water-surface elevation of a pond changes not only seasonally but also with time (nonseasonal). It is assumed in the OPOND program that the top level of the upper zone and bottom level of the lower zone are kept unchanged. The rule curve of a pond changes between the top level of the upper zone and the bottom level of the lower zone with time. Input instructions and explanations of variables for rule-curve elevations are listed in table 34. The file-identification code is 20 .

Table 34. File format for time-dependent, pond rule-curve elevations (file-identification code 20 used in OPONDS computer program)

[ft, feet; in., inches; mm, millimeters; --, not applicable]

\begin{tabular}{|c|c|c|c|c|}
\hline $\begin{array}{l}\text { State- } \\
\text { ment } \\
\text { num- } \\
\text { ber }\end{array}$ & $\begin{array}{l}\text { Information at } \\
\text { statement }\end{array}$ & Variable & Definition & $\begin{array}{c}\text { Variable } \\
\text { type }\end{array}$ \\
\hline $1-5$ & Title lines & -- & -- & - \\
\hline 6 & Unit & RCUNIT & $\begin{array}{l}\text { Rule-curve elevation unit code }(0-\mathrm{ft} \text {; } \\
1-\text { in.; } 2-\mathrm{mm}) \text {. }\end{array}$ & integer \\
\hline 7 & $\begin{array}{l}\text { List of nodal } \\
\text { names }\end{array}$ & $\begin{array}{l}\text { TIME } \\
\text { NAME(J), J } \\
=1 \text {, } \\
\text { NRCND }\end{array}$ & $\begin{array}{l}\text { Time. } \\
\text { Pond nodal names (see note } 1 \text { ). NRCND is } \\
\text { the number of nodes with time-dependent } \\
\text { rule curves. }\end{array}$ & $\begin{array}{l}\text { character } \\
\text { character }\end{array}$ \\
\hline 8 & $\begin{array}{l}\text { Rule-curve ele- } \\
\text { vations for each } \\
\text { time period }\end{array}$ & $\begin{array}{l}\text { TIME } \\
(\mathrm{RCTB} \\
(0, \mathrm{~J}), \mathrm{J}=1 \\
\text { NRCND) }\end{array}$ & $\begin{array}{l}\text { Time. } \\
\text { Rule-curve elevations (see note } 2 \text { ). }\end{array}$ & $\begin{array}{c}\text { character } \\
\text { real }\end{array}$ \\
\hline
\end{tabular}

Notes:

1. Use the nodal name DEFAULT for nodes with the same pond rule curves. The DEFAULT node must follow the other specified nodes (that is, in last column).

2. If both seasonal and nonseasonal values are specified for the same node, only nonseasonal values are used. 


\section{Time-Dependent, Flow-Boundary File}

The time-dependent, flow-boundary file is used to specify flow boundaries that change with time for selected flow zones in canals. Input instructions and explanations of variables are listed in table 35 . The file-identification code is 21 .

Table 35. File format for time-dependent flow boundaries (file-identification code 21 used in OPONDS computer program)

[acre-ft, acre-feet; $\mathrm{ft}^{3} / \mathrm{s}$, cubic feet per second; $\mathrm{ft}^{3} / \mathrm{d}$, cubic feet per day; --, not applicable; >, greater than; <, less than]

\begin{tabular}{|c|c|c|c|c|}
\hline $\begin{array}{l}\text { State- } \\
\text { ment } \\
\text { num- } \\
\text { ber }\end{array}$ & $\begin{array}{l}\text { Information at } \\
\text { statement }\end{array}$ & Variabie & Definition & $\begin{array}{c}\text { Variable } \\
\text { type }\end{array}$ \\
\hline $1-5$ & Title lines & -- & -- & - \\
\hline 6 & Unit & FBUNIT & $\begin{array}{l}\text { Flow unit code }\left(0-\text { acre-ft; } 1-\mathrm{ft}^{3} / \mathrm{s} \text {; }\right. \\
\left.2-\mathrm{ft}^{3} / \mathrm{d}\right) \text {. }\end{array}$ & integer \\
\hline 7 & $\begin{array}{l}\text { List of upstream } \\
\text { nodal names }\end{array}$ & $\begin{array}{l}\text { NAME(J), J } \\
=1, \\
\text { NFBAR }\end{array}$ & $\begin{array}{l}\text { From-node names. NFBAR is the number } \\
\text { of arcs with flow boundaries. }\end{array}$ & character \\
\hline 8 & $\begin{array}{l}\text { List of down- } \\
\text { stream nodal } \\
\text { names }\end{array}$ & $\begin{array}{l}\text { NAME(J), J } \\
=1, \\
\text { NFBAR }\end{array}$ & To-node names. & character \\
\hline 9 & Flow-zone index & $\begin{array}{l}\text { TIME, } \\
\text { (FBIDX(J), } \\
\mathrm{J}=1 \\
\text { NFBAR) }\end{array}$ & $\begin{array}{l}\text { Time. } \\
\text { Flow-zone index }(-1, \text { lower boundary of } \\
\text { normal flow zone; }+1 \text {, upper boundary of } \\
\text { normal flow zone; }<-2 \text {, lower extended } \\
\text { flow zone; }>+2 \text {, upper extended flow zone; } \\
\text { that is, index = zone } \pm 1) \text {. }\end{array}$ & $\begin{array}{c}\text { character } \\
\text { integer }\end{array}$ \\
\hline 10 & $\begin{array}{l}\text { Flow boundaries } \\
\text { for each time } \\
\text { period }\end{array}$ & $\begin{array}{l}\text { TIME, } \\
\text { (FBTB(0,J), } \\
\mathrm{J}=1, \\
\text { NFBAR), }\end{array}$ & $\begin{array}{l}\text { Time. } \\
\text { Flow boundaries (see notes } 1 \text { and } 2 \text { ). }\end{array}$ & $\begin{array}{l}\text { character } \\
\text { real }\end{array}$ \\
\hline
\end{tabular}

Notes:

1. For lower or upper extended flow zone, set flow boundaries equal to corresponding flow-zone capacities.

2. If both seasonal and nonseasonal values are specified for the same flow zone in the same flow arc, only nonseasonal values are used.

\section{Ground-Water Elevation File}

Ground-water data are used to estimate seepage from ponds and canals. Ground-water elevations are conceptually specified at nodes. Input instructions and explanations of variables for ground-water data are described in table 36. The file-identification code is 22 . 
Table 36. File format for ground-water elevations (file-identification code 22 used in OPONDS computer program)

[ft, feet; in., inches; $\mathrm{mm}$, millimeters; acre-ft/d, acre-feet per day; $\mathrm{ft}^{3} / \mathrm{s}$, cubic feet per second; $\mathrm{ft}^{3} / \mathrm{d}$, cubic feet per day; --, not applicable]

\begin{tabular}{|c|c|c|c|c|}
\hline $\begin{array}{l}\text { State- } \\
\text { ment } \\
\text { num- } \\
\text { ber }\end{array}$ & $\begin{array}{l}\text { Information at } \\
\text { statement }\end{array}$ & Variable & Definition & $\begin{array}{c}\text { Variable } \\
\text { type }\end{array}$ \\
\hline $1-5$ & Title lines & -- & -- & -- \\
\hline 6 & $\begin{array}{l}\text { Data unit and } \\
\text { type }\end{array}$ & $\begin{array}{l}\text { GWUNIT } \\
\text { GWTYPE }\end{array}$ & $\begin{array}{l}\text { Data unit code (if gwtype }=1,0-\mathrm{ft} ; 1-\text { in.; } \\
2-\mathrm{mm} ; \text { if gwtype }=2,0-\text { acre-ft/d; } \\
\left.1-\mathrm{ft}^{3} / \mathrm{s} ; 2-\mathrm{ft}^{3} / \mathrm{d}\right) \\
\text { Data type code }(1-\text { level; } 2-\mathrm{flux})\end{array}$ & $\begin{array}{l}\text { integer } \\
\text { integer }\end{array}$ \\
\hline 7 & $\begin{array}{l}\text { List of nodal } \\
\text { names }\end{array}$ & $\begin{array}{l}\text { TIME } \\
\text { (NAME(J), J } \\
=1, \\
\text { NGWND) }\end{array}$ & $\begin{array}{l}\text { Time. } \\
\text { Nodal names (see note 1). NGWND is the } \\
\text { number of nodes with ground-water data. }\end{array}$ & $\begin{array}{l}\text { character } \\
\text { character }\end{array}$ \\
\hline 8 & $\begin{array}{l}\text { Ground-water } \\
\text { level or flux for } \\
\text { each time } \\
\text { period }\end{array}$ & $\begin{array}{l}\text { TIME, } \\
\text { GWLVL(I), } \\
I=1 \\
\text { NGWND }\end{array}$ & $\begin{array}{l}\text { Time. } \\
\text { Ground-water elevation or flux (see note 2). }\end{array}$ & $\begin{array}{l}\text { character } \\
\text { real }\end{array}$ \\
\hline
\end{tabular}

\section{Fixed-Flow File}

One special case of canal flows is when flows are fixed to a certain amount for a given time period. This implies that there are no extended flow zones and that flow in the normal flow zone is constant in the network model. The fixed-flow file is used to specify fixed flows for selected canals. Input instructions and explanations of variables are described in table 37. The file-identification code is 23 .

Table 37. File format for fixed flows (file-identification code 23 used in OPONDS computer program)

[acre-ft, acre-feet; $\mathrm{ft}^{3} / \mathrm{s}$, cubic feet per second; $\mathrm{ft}^{3} / \mathrm{d}$, cubic feet per day; --, not applicable]

\begin{tabular}{|c|c|c|c|c|}
\hline $\begin{array}{l}\text { State- } \\
\text { ment } \\
\text { num- } \\
\text { ber }\end{array}$ & $\begin{array}{l}\text { Information at } \\
\text { statement }\end{array}$ & Variable & Definition & $\begin{array}{c}\text { Variable } \\
\text { type }\end{array}$ \\
\hline $1-5$ & Title lines & - & -- & -- \\
\hline 6 & Flow unit & FIXCD & $\begin{array}{l}\text { Flow unit code ( } 0 \text {-acre-ft; } 1-\mathrm{ft}^{3} / \mathrm{s} \\
\left.2-\mathrm{ft}^{3} / \mathrm{d}\right)\end{array}$ & integer \\
\hline 7 & $\begin{array}{l}\text { List of upstream } \\
\text { nodes }\end{array}$ & $\begin{array}{l}\text { (NAME(J), } \\
\mathbf{J}=1, \\
\text { NFIX) }\end{array}$ & $\begin{array}{l}\text { Upstream nodal names. NFIX is the number } \\
\text { of arcs with fixed flows. }\end{array}$ & character \\
\hline 8 & $\begin{array}{l}\text { List of down- } \\
\text { stream nodes }\end{array}$ & $\begin{array}{l}\text { TIME } \\
\text { NAME(J), } \\
\mathbf{J}=1, \text { NFIX }\end{array}$ & $\begin{array}{l}\text { Time. } \\
\text { Downstream nodal names. }\end{array}$ & $\begin{array}{l}\text { character } \\
\text { character }\end{array}$ \\
\hline
\end{tabular}


Table 37. File format for fixed flows (file-identification code 23 used in OPONDS computer program)-Continued

\begin{tabular}{|c|c|c|c|c|}
\hline $\begin{array}{l}\text { State- } \\
\text { ment } \\
\text { num- } \\
\text { ber }\end{array}$ & $\begin{array}{l}\text { Information at } \\
\text { statement }\end{array}$ & Variable & Definition & $\begin{array}{c}\text { Variable } \\
\text { type }\end{array}$ \\
\hline 9 & $\begin{array}{l}\text { Fixed flow for } \\
\text { each time } \\
\text { period }\end{array}$ & $\begin{array}{l}\text { TIME } \\
Q(I), I=1, \\
\text { NFIX }\end{array}$ & $\begin{array}{l}\text { Time. } \\
\text { Fixed flow. }\end{array}$ & $\begin{array}{c}\text { character } \\
\text { real }\end{array}$ \\
\hline
\end{tabular}

\section{Network-Configuration Output File}

The network-configuration output file is used to summarize input data and the basic network configuration and to store error messages during program execution. The file-identification code is 26 . The output file name with the file-identification code 26 must be specified in the master data file. See a sample output in Appendix D for the sample problem.

\section{Nodal-Budget Output File}

The nodal-budget output file is used to store nodal budgets for each time period. The output for general nodes includes upstream inflows, local net inflows, surface runoff, water withdrawals, and total outflows from nodes. In addition to these budget terms, budget items for initial storage, surface-water evaporation, bottom seepage, and final storage are added for the pond-budget output. The file-identification code is 27 . The output file name with the file-identification code 27 must be specified in the master data file. If the file name is not specified, no nodal water-budget output will be generated.

\section{Canal-Routing Output File}

The canal-routing output file summarizes the canal-routing results, which include canal initial storage, inflow, canal seepage, water-surface evaporation, canal final storage, and outflow from each canal. The file-identification code is 28 . The output file name with the file-identification code 28 must be specified in the master data file (see tables 16 and 17). If the file name is not specified, no canal water-budget output will be generated.

\section{Outlet Hydraulic-Structure Output File}

The output file includes outlet hydraulic-structure information, flow through structure, and structure operation. The structure information includes structure name, type, location, and size. Structure operation means the gate opening height or sharp-crested weir height. The file-identification code is 29 . The output file name with the file-identification code 29 must be specified in the master data file (see tables 16 and 17).

\section{List of Nodes for Time-Series Output of Water Budget}

This file is used to list selected nodes for which time-series output of water budgets are needed. For the nodal listing, the file-identification code is 30 . To specify a node, one nodal name is one record in the file. Two time-series output files for each of the specified nodes are generated. The first output file is for the nodal water budget with the output file as "nb_\{nodal_name\}.dat", where \{nodal_name\} is the specified nodal name. The second output file is for downstream releases from a specified node. The name of this output file is "nr_\{nodal_name\}.dat". If the pro- 
gram runs on PC MS-DOS, nodal names are limited to five characters because a file name in PC DOS is limited to eight characters.

\section{List of Canals for Time-Series Output of Canal-Routing Results}

This file is used to list selected canals for which time-series output of routing results are needed. For the canal listing, the file-identification code is 31 . A canal is represented by upstream and downstream nodal names. One record is specified for each selected canal in the file. The time-series output of the water budget will be saved in separated files for each selected canal. The output file name is of the form "arbud\#\#\#.out", where \#\#\# is the sequential number of selected canals in the file. 
Selected variables from the OPONDS program and their definitions are listed along with the variable type, which is presented in parentheses. If a variable is an array, the array dimension is also presented in parentheses.

ARBFLG-Logical indicator for arc budget output (LOGICAL).

ARC - Index variable for the current arc (INTEGER).

ARCBUD - List of budget terms for canal routing (unsigned) (LDARC X 0:6; INTEGER).

0 -Downstream node of a canal reach.

1-Inflow.

2-Initial storage.

3-Canal seepage.

4 - Canal water-surface evaporation.

5-Final storage.

6-Outflow.

ARCS - Number of arcs in a basic network (that is, number of physical arcs in the original network) (INTEGER).

ARTYP-List of arc types (LDARC X 1; INTEGER).

1 -Canal-flow arc: abcd.

$\mathrm{a}=+$ if normal or upper extended flow zone;

- if lower extended flow zone.

$\mathrm{b}=1$.

$c=0$ if not a stream arc;

1 if a stream arc.

$\mathrm{d}=0$ if normal flow zone:

$>0$ if extended flow zone number.

2-Pond-storage arc:

$\mathrm{a}=+$ upper storage zone;

- lower storage zone.

$b=2$.

$\mathrm{c}=0$.

$\mathrm{d}=$ zone number $(1,2, \ldots)$.

3-Pond net value arc.

4-Pond evaporation arc or seepage arc.

5-Surface-runoff arc.

6-Water-demand arc.

7-Local inflow arc.

8- Canal initial-storage arc.

9-Canal final-storage arc.

10-Canal-seepage arc.

11-Canal-evaporation arc.

CARBT - Cumulative arc budgets for whole system (6x 1; REAL).

1-Inflow.

2-Initial storage.

3-Canal seepage.

4 - Canal water-surface evaporation.

5 -Final storage.

6-Outflow from the system.

CNDBT - Cumulative nodal budget for whole system (0:10 x 1; REAL).

0 -Initial storage (acre-feet).

1 -Upstream inflow (acre-feet).

2-Local inflow (acre-feet).

3-Evaporation loss for a pond node (acre-feet). 
4 -Precipitation gain (acre-feet).

5-Seepage loss for pond node (acre-feet).

6-Water withdrawal (acre-feet).

7-Total downstream release (acre-feet).

8-Final storage for pond node (acre-feet).

COLSTR-Array of strings for general purposes (LDCOL X 1; CHARACTER*30).

CONST - Constant coefficient converting acre-feet per month to cubic feet per second $(=86,400 / 43,560=1.98347)$

(REAL).

COST-Array of penalty coefficients of arcs (LDARC X 1; INTEGER).

CSARBT-Array of cumulative water budgets for arcs (LDARC x 0:6; REAL).

0 -Downstream node of a canal reach.

1 -Inflow.

2-Initial storage.

3-Canal seepage.

$4-$ Canal water-surface evaporation.

5-Final storage.

6-Outflow.

CSNDBT-Array of cumulative nodal budgets for nodes (LDND x 0:10; REAL).

0 - Initial storage (acre-feet).

1 -Upstream inflow (acre-feet).

2-Local inflow (acre-feet).

3-Evaporation loss for pond node (acre-feet).

4 -Precipitation gain (acre-feet).

5-Seepage loss for pond node (acre-feet).

6-Water withdrawal (acre-feet).

7-Total downstream release (acre-feet).

8-Final storage for pond node (acre-feet).

CTARFW - List of control arc and lower and upper flow boundaries (LDCTAR X 3; INTEGER).

0 - Control arc number.

1 -Lower flow boundary.

2-Upper flow boundary.

CTERM-A temporary string (char*500).

DEBUG-Logical variable for optimal solution (LOGICAL).

ERR-Error flag (LOGICAL).

EVFIL - Logical indicator for time-dependent evaporation from a file (LOGICAL).

EVFLAG-Logical indicator for pond water-surface evaporation (LOGICAL).

EVND - List of nodes with water-surface evaporation (LDEV X 3; INTEGER).

1 -Nodal number.

2-Data unit code (0-millimeter per day; 1 -inches per day; 2-feet per day).

3-Sequential number for time-dependent data.

If zero, seasonal data will be used. If negative, the default value is used.

EVTB-Array of seasonal water-surface evaporation coefficients (0:LDP X LDEV; REAL).

EVUNIT-Evaporation coefficient unit code (INTEGER).

FBAR - List of flow-boundary arc information (0:7 X LDFBAR; INTEGER).

0 - Signed flow-boundary arc.

1-Upstream node.

2-Downstream node.

3-Flow-zone index. index $=$ zone number \pm 1 .

(-1 lower boundary of normal flow range;

+1 upper boundary of normal flow range;

$<=-2$ lower extended flow zone; 
$>=2$ upper extended flow zone).

4-Next extended arc 1.

5 -Next extended arc 2.

6-Data unit code (0-acre-feet; 1 -cubic feet per second; 2-cubic feet per day).

7-Seasonal or time-dependent index ( 0 - seasonal, $>0$ - time dependent).

FBFIL-Logical indicator for time-dependent flow boundary from a file (LOGICAL).

FBFLAG-Logical indicator for existing flow-boundary arcs (LOGICAL).

FBTB - List of seasonal or time-dependent flow boundaries for selected arcs (0:LDFBTB X LDFBAR; REAL).

FBUNIT-Unit code for flow boundaries (INTEGER).

(0-acre-feet; 1 - cubic feet per second; 2 -cubic feet per day).

FCRIT-Flow-convergence criterion (INTEGER).

FILNAM - List of data and output file names (0:LDFIL X 1; CHAR*30).

FLAG-Logical indicator (LOGICAL).

FLOW-Array of flows in arcs (LDARC X 1; INTEGER).

FLWARC-Logical indicator for canal routing (LOGICAL).

FWFLAG - Indicator for existing local incremental inflow (LOGICAL).

FXAR - List of fixed-flow arc and associated upstream and downstream nodes (0:2 X LDFXAR; INTEGER).

0 -Arc number.

1-Upstream node.

2-Downstream node.

FXFLAG - Logical variable for fixed flow (LOGICAL).

FXUNIT-Fixed-flow unit code (INTEGER).

(0-acre-feet; 1 -cubic feet per second; 2 - cubic feet per day).

GWFLAG-Logical indicator for ground-water discharge (LOGICAL).

GWLVL—List of ground-water elevations (LDGWND X 1; REAL).

GWND-List of nodes with ground-water seepage (LDGWND X 3; INTEGER).

1 -Nodal number.

2-Data unit code (0-feet; 1 -inches; 2 -millimeters).

3-Sequential number for time-dependent data. If zero, seasonal data will be used.

GWTYPE - Ground-water data type (INTEGER).

(1-elevation; 2-flux).

GWUNIT - Ground-water-data unit (0:2 x2; CHARACTER*6).

HI-Array of upper flow boundaries of arcs (LDARC X 1; INTEGER).

HYBFLG-Logical indicator for outputting water budgets through outlet hydraulic structures (LOGICAL).

HYDAT-List of hydraulic-structure parameters (LDHY X 5; REAL).

1 -Base elevation (feet).

2-Weir length or pipe diameter (feet).

3-Weir height or pipe length (feet).

$4-$ Gate opening height (feet) or pipe-friction factor.

5-Pipe-loss factor in constrictions and entrances.

HYDIR - Array for structure and associated upstream and downstream nodal names (LDHY X 0:2; CHAR*12).

$0-$ Structure name.

1 -Upstream nodal name.

2-Downstream nodal name.

HYOUT - Array for results for hydraulic-structure operation (LDHY X 3; REAL).

1-Flow-through structure (cubic feet per second).

2-Water level of an upstream node (feet).

3 - Gate opening height or weir height (feet).

HYTP - Array of names of hydraulic-structure types available (0:LDHYTP X 1; CHAR*20).

HYTPCD-Array of structure type codes and downstream arcs (LDHY X 0:1; INTEGER).

$0-$ Structure type code.

1 -Rectangle sharp-crested weir.

2-Vertical flat gate on spillway. 
3-Vertical flat gate on broad-crested weir.

6-Pipe.

1-Downstream arc number.

I-Index variable (INTEGER).

IFAULT-Index variable for fault code (INTEGER).

IFWCD—Local net inflow unit code (INTEGER).

0 -Acre-feet.

1 - Cubic feet per second (cubic feet per second).

2-Cubic feet per day (cubic feet per day).

IFWND—List of nodes with local incremental flows (LDIFW X 3; INTEGER).

1 -Nodal number.

2-Data unit code (0-acre-feet; 1 - cubic feet per second; 2 - cubic feet per day).

3 -Sequential number for time-dependent data. IF $<0$, use default value.

II-An array of upstream nodes for directed arcs (LDARC X 1; INTEGER).

IN-FORTRAN file unit for general network data file (INTEGER).

INST - Array of initial storages at each time step (LDRES X 1; REAL).

IN_EV_FORTRAN file unit for evaporation coefficient (INTEGER).

IN_FB-FORTRAN file unit for time-dependent flow boundaries (INTEGER).

IN_FX-FORTRAN file unit for fixed-flow data (INTEGER).

IN_GW-FORTRAN file unit for ground-water-level data (INTEGER).

IN_IFW-FORTRAN file unit for local incremental inflow (INTEGER).

IN_RC-FORTRAN file unit for time-dependent rule curve (INTEGER).

IN_RN_FORTRAN file unit for precipitation data (INTEGER).

IN_WS-FORTRAN file unit for target water-demand data (INTEGER).

ISGN-INTEGER function for the sign of an INTEGER (INTEGER).

J-Index variable (INTEGER).

JJ-Array of downstream nodes of directed arcs (LDARC X 1; INTEGER).

KARC - The current out-of-kilter arc (INTEGER).

LAST - Logical indicator at the ending of a file (LOGICAL).

LDARC - Leading dimension for number of arcs in a network (INTEGER).

LDCOL_Leading dimension for the array COLSTR (INTEGER).

LDCTAR - Leading dimension for number of control arcs (INTEGER).

LDEV - Leading dimension for number of nodes with water-surface evaporation (INTEGER).

LDFBAR - Leading dimension for flow-boundary arcs (INTEGER).

LDFBTB - Leading dimension for flow-boundary data matrix (INTEGER).

LDFIL-Leading dimension for number of input-output files (INTEGER).

LDFXAR - Leading dimension for number of fixed-flow arcs (INTEGER).

LDGWND - Leading dimension for number of nodes with ground-water data (INTEGER).

LDHY - Leading dimension for number of hydraulic structures (INTEGER).

LDHYTP - Leading dimension for number of outlet-structure types (INTEGER).

LDIFW-Leading dimension for number of nodes with local incremental inflow (INTEGER).

LDITR -Leading dimension for number of iterations (INTEGER).

LDND-Leading dimension for number of nodes (INTEGER).

LDP-Leading dimension for number of seasons in a year (INTEGER).

LDPL_Leading dimension for pool space (INTEGER).

LDRAIN_Leading dimension for number of nodes with precipitation (INTEGER).

LDRC - Leading dimension for number of nodes with time-dependent rule curves (INTEGER).

LDRCTB - Leading dimension for rule-curve table (INTEGER).

LDREAR - Leading dimension for number of pond arcs (INTEGER).

LDRES - Leading dimension for number of pond nodes (INTEGER).

LDRETB - Leading dimension for number of pond-characteristic table (INTEGER). 
LDRFTB-Leading dimension for runoff data table RNOFTB (INTEGER).

LDRNOF - Leading dimension for number of nodes with the surface-runoff data (INTEGER).

LDSABL - Leading dimension for number of single-arc budget lists (INTEGER).

LDSNBL_Leading dimension for number of single-node budget lists (INTEGER).

LDSTR-Leading dimension for number of stream arcs (INTEGER).

LDSTRM - Leading dimension for number of stream-routing arcs (INTEGER).

LDUNIT-Leading dimension for number of units used (INTEGER).

LDWS-Leading dimension for number of water-demand nodes (INTEGER).

LO-Array of lower flow boundaries (LDARC X 1; INTEGER).

MNTH-Current season in characters (CHARACTER *5).

MTH-Current season in numbers such as $1,2, \ldots$ (INTEGER).

MXCST-Maximum value of penalty coefficients (INTEGER).

NARCND - Number of arc nodes (that is, stream nodes) (INTEGER).

NARCS - Number of arcs in a network (INTEGER).

NDBFLG-Logical indicator for outputting the nodal water budgets (LOGICAL).

NDDWAR - Array of downstream flow arcs from nodes (LDARC X 1; INTEGER).

NDNAM-List of nodal names (LDND X 1; CHAR*12).

NDSEQ - List of nodal sequential numbers (LDND X 1; INTEGER).

NDTYP-List of nodal types (LDND X 1; INTEGER).

1 -Pond node.

2 - General node.

NDWAR-Number of downstream arcs (INTEGER).

NDXAR - List of signed extensional arcs associated with a node (LDND X 6; INTEGER).

1 -Pond net-value arc or local net inflow arc.

2-Water-surface-evaporation arc.

3-Precipitation arc.

4-Pond-seepage arc.

5-Target water-demand arc.

6-Target water-demand deviation arc.

NEV - Number of evaporation nodes (INTEGER).

NFBAR-Number of flow-boundary arcs (INTEGER).

NFXAR - Number of arcs with time-dependent, fixed flows (INTEGER).

NGWND - Number of ground-water nodes (INTEGER).

NHY - Number of hydraulic structures (INTEGER).

NHYTP-Number of outlet structure types supported (INTEGER).

NIFW-Number of nodes with local incremental inflows (INTEGER).

NITR-Number of iteration steps (INTEGER).

NNODS - Number of active nodes in a network (that is, original nodes) (INTEGER).

NODBUD - List of budget terms for nodal budgets (LDND X 0:10; INTEGER).

0 -Initial storage for a pond node (acre-feet).

1 -Upstream inflow (acre-feet).

2-Local inflow (acre-feet).

3-Evaporation loss for pond node (acre-feet).

4 -Precipitation runoff (acre-feet).

5-Seepage loss for pond node (acre-feet).

6-Water withdrawal (acre-feet).

7-Total downstream release (acre-feet).

8 -Final storage for pond node (acre-feet).

NOP-Index for the current time period (INTEGER).

NOTCOV-Logical convergence indicator (LOGICAL).

NPER-Number of seasons in a year (INTEGER).

NRAIN - Number of nodes with precipitation (INTEGER).

NRCND - Number of nodes with time-dependent, rule curves (INTEGER). 
NRES - Number of pond nodes (INTEGER).

NRNOF-Number of surface-runoff nodes (INTEGER).

NSABL - Number of arcs needed to output single-arc budget (INTEGER).

NSNBL - Number of nodes needed to output nodal budget (INTEGER).

NSPS-Number of simulation periods (INTEGER).

NSTR-Number of stream reaches with geometrical data (INTEGER).

NSTRM-Number of stream-routing arcs (INTEGER).

NTLS-Number of non-data lines in a data file (INTEGER).

NWSND-The number of water-demand nodes (INTEGER).

OARCS—Old arc (INTEGER).

OCF-Array of old stream coefficients (canal storage) (LDSTRM X 1; REAL).

OFLOW-Array of old flows (LDARC X 1; INTEGER).

OHI-Array of old high boundaries of arcs (LDARC X 1; INTEGER).

OINST - List of old initial pond storages (LDRES X 1; REAL).

OU_AR-FORTRAN unit for outputting arc budgets (INTEGER).

OU_HY_FORTRAN unit for outputting operating hydraulic structures (INTEGER).

OU_ND_FORTRAN unit for outputting nodal budgets (INTEGER).

OU_NT-FORTRAN unit for outputting network configuration (INTEGER).

OU_SA-FORTRAN unit for file listing arcs for which single-arc budgets are needed (INTEGER).

OU_SN_FORTRAN unit for file listing nodes for which single-node budgets are needed (INTEGER).

PERD - Number of days for each time period (REAL).

PN-Part number (INTEGER).

PTDWAR - Pointer of downstream arcs from a node (LDND X 2; INTEGER).

1-Pointer for first downstream arc.

2-Pointer for the last downstream arc.

PTRE-Pointer of pond-storage arcs for pond nodes (LDRES X 1; INTEGER).

PTRES-Pointer of pond nodes (that is, list of pond nodes) (LDRES X 1; INTEGER).

RAINND—List of nodes with precipitation (LDRAIN X 3; INTEGER).

1 -Nodal number.

2-Data unit code (0-feet; 1 -inches; 2 -millimeters).

3-Sequential number for time-dependent data. If zero, seasonal data will be used.

RAINTY - Surface-runoff data type (INTEGER).

(1-precipitation; 2-flux)

RC-Array of pond rule curves in volume (LDRES X 1; REAL).

RCFIL-Logical indicator for time-dependent, rule curves from a file (LOGICAL).

RCFLAG-Logical indicator for time-dependent, rule curves (LOGICAL).

RCND - List of nodes with time-dependent, rule curves (LDRC X 3; INTEGER).

1 -Nodal number.

2-Data unit code ( 0 -feet; 1 -inches; 2 -millimeters).

3-Sequential number for time-dependent data. If zero, seasonal data will be used.

RCTB-Array of time-dependent, rule curves (0:LDRCTB X LDRC; INTEGER).

RCUNIT-Rule-curve unit code (INTEGER).

REAR-Array of pond-storage arcs (LDREAR X 1; INTEGER).

RESDAT-Pond-bottom information (LDRES X 0:2; REAL).

0 -Pond-bottom elevation (feet).

1-Pond-bed hydraulic conductivity (feet per day).

2-Pond-bed thickness (feet).

REZN-Array of pond-storage zone capacities (LDREAR X 1; REAL).

RNFLAG-Indicator for existing rain data (LOGICAL).

RNOFND - List of nodes with surface runoff (LDRNOF X 1; INTEGER).

RNOFTB-Array of surface-runoff data (LDRNOF X 0:LDRFTB; REAL).

0 -Initial 5-day antecedent rainfall, in inches. 
1-5-day antecedent rainfall for dry condition, in inches.

2-5-day antecedent rainfall for wet condition, in inches.

3-Drainage area, in acres.

4 -SCS curve number for average condition (II).

RNUNIT_-Precipitation unit code (INTEGER).

(0-feet; 1 -inches; 3 -millimeters)

RPOOL_Pool space (LDPL X 1; REAL).

RTERM-Temporary REAL number (REAL).

SABLFG-Logical indicator for single-arc budget list (LOGICAL).

SABLND—List of arcs with single-arc budget list (LDSABL X 3; INTEGER).

1-Upstream node number.

2-Downstream node number.

3-FORTRAN unit for output budget.

SAVOPT - Save option for general output (INTEGER).

0 -Both input data-file information and network configuration.

1 -Input data-file information.

2-Network configuration.

SKSC-Sink/source node (INTEGER).

SNBLFG-Logical indicator for single-node budget list (LOGICAL).

SNBLND-List of nodes with single-node budget list (LDSNBL X 3; INTEGER).

1 -Nodal number.

2-FORTRAN unit for water-budget output.

3-FORTRAN unit for downstream water releases.

STMO-Starting season of simulation period in number (INTEGER).

STRDAT - List of canal-geometry data (LDSTR X 9; REAL).

1 -Canal-bed roughness (dimensionless).

2-Canal-reach length (feet).

3-Average canal-bed slope (dimensionless).

4 - Canal-base width (feet).

5-Canal-side slope (dimensionless).

6-Canal depth (feet).

7 - Canal-bed hydraulic conductivity (feet per day).

8-Thickness of canal bed (feet).

9-Canal-bed elevation at reach entry (feet above sea level).

STRDIR-List of nodes associated with stream arcs (LDSTR X 3; INTEGER).

1-Upstream node.

2-Downstream node.

3-Middle routing node.

STRMAR-List of arcs for canal routing. Arc number is signed (LDSTRM X 0:6; INTEGER).

0 - Stream nodal number.

1 -Signed inflow arc number.

2 - Signed initial canal-storage arc number.

3 - Canal-seepage arc number.

4-Evaporation arc.

5-Final storage arc.

6-Outflow arc.

STRMCF - List of canal-routing coefficients (LDSTRM X 0:4; REAL).

0 - Canal initial storage (acre-feet).

1 -Traveltime $(K)$ (days).

2-Weighting factor $(x)(0-0.5$, dimensionless).

3 - Seepage coefficient (dimensionless).

$>0$, in percentage of inflow $(<1.0,0.01 \sim 0.02)$.

$<0$, seepage will be calculated by Darcy's law.

4-Evaporation coefficient (inches per day). 
SYSNAM - Name of a system of ponds (CHAR*30).

UNITNM_1-Unit name for discharge (0:2 X 1; CHAR*6).

0 -acre-feet.

$1-$ cubic feet per second.

2 - cubic feet per day.

UNITNM_2_Unit name for length (0:2 X 1; CHAR*6).

0 -feet.

1 -inches.

2-millimeters.

UNITNM_3-Unit name for rate (0:2 X 1; CHAR*6).

0 -millimeters per day.

1 -inches per day.

2-feet per day.

WSFIL_Logical indicator for target water demand from a file (LOGICAL).

WSFLAG - Logical indicator for target water demand (LOGICAL).

WSND—List of nodes with target water demand (LDWS X 3; INTEGER).

1 -Nodal number.

2-Data unit code ( 0 -acre-feet; 1 - cubic feet per second; 2 - cubic feet per day).

3-Sequential number for time-dependent data. If zero, seasonal data will be used.

WSTB -Array of time-dependent or seasonal target water demands (0:LDP X LDWS; REAL).

WSUNIT - Target water-demand unit code (INTEGER).

( 0 -acre-feet; 1 - cubic feet per second; 2 - cubic feet per day).

XF-Exaggerator factor (REAL).

XP-Number of decimal points for water budget, in acre-feet (INTEGER).

YEAR - Current year (INTEGER).

YES-Logical variable for yes or no (LOGICAL).

YR-Year (INTEGER).

ZEROFG-Logical indicator for zero (LOGICAL). 


\section{APPENDIX D. CONCEPTUAL SAMPLE PROBLEM}

The conceptual sample problem is intended to illustrate the use of the computer program OPONDS for operation of a system of canals and control ponds, especially input data files and output from the program. The conceptual flow system used in this sample problem contains three ponds, three pumping stations for water supply, and three hydraulic structures to control water releases from the ponds (fig. 17). The sample problem specifies that three ponds should be operated to satisfy the downstream water demands at three pumping stations and the minimum flow requirements in channels and to keep pond water levels as close to target levels as possible. In the following section, the input data files for the sample problem are discussed first, and then output files are presented. The data in this sample problem are hypothetical.

\section{Input Data for Conceptual Sample Problem}

There are 18 input data files for this sample problem. Contents of these files are described in the following section. For the file format and variable definitions, refer to the input/output instructions in Appendix B.

\section{Master Data File (mdf.dat)}

The master data file is used to list all file names for input and output and their associated file-identification codes. The contents of master data file for the sample problem are listed as follows:

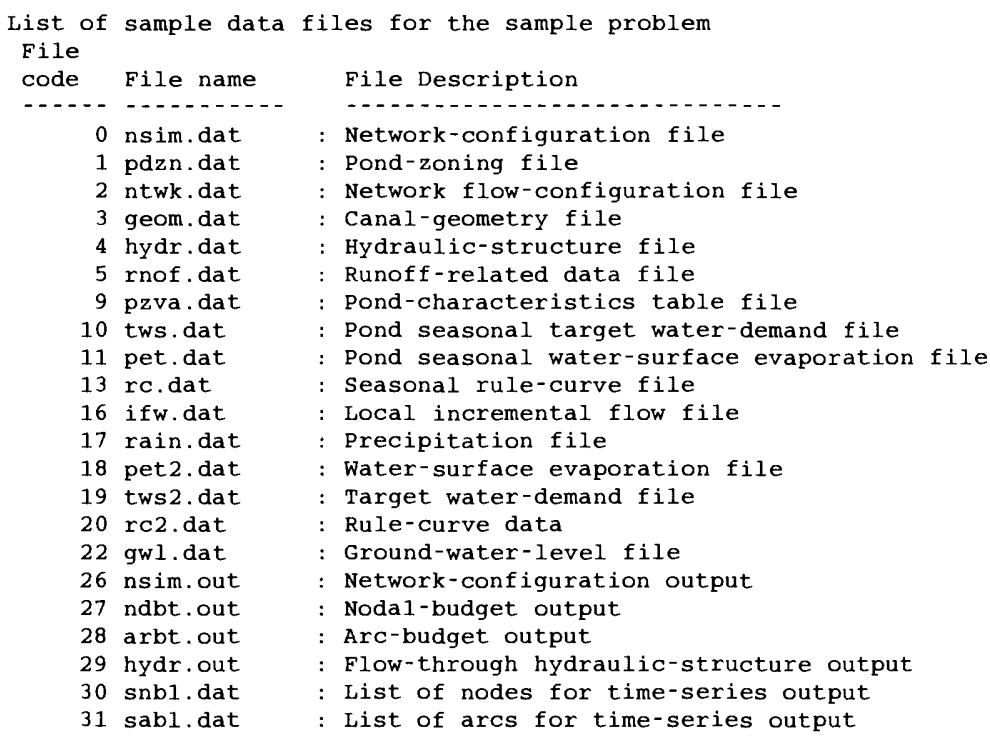

\section{General Network-Configuration and Parameter File (nsim.dat)}

This file is used to specify the simulation period, accuracy of results, and so forth. It is noted that data for network construction and seasonal data also can be included in this file.

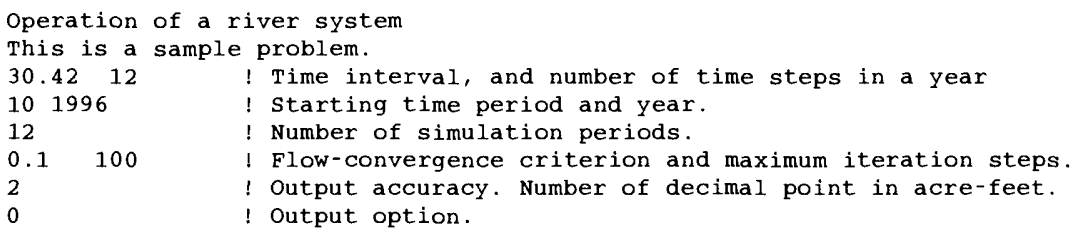




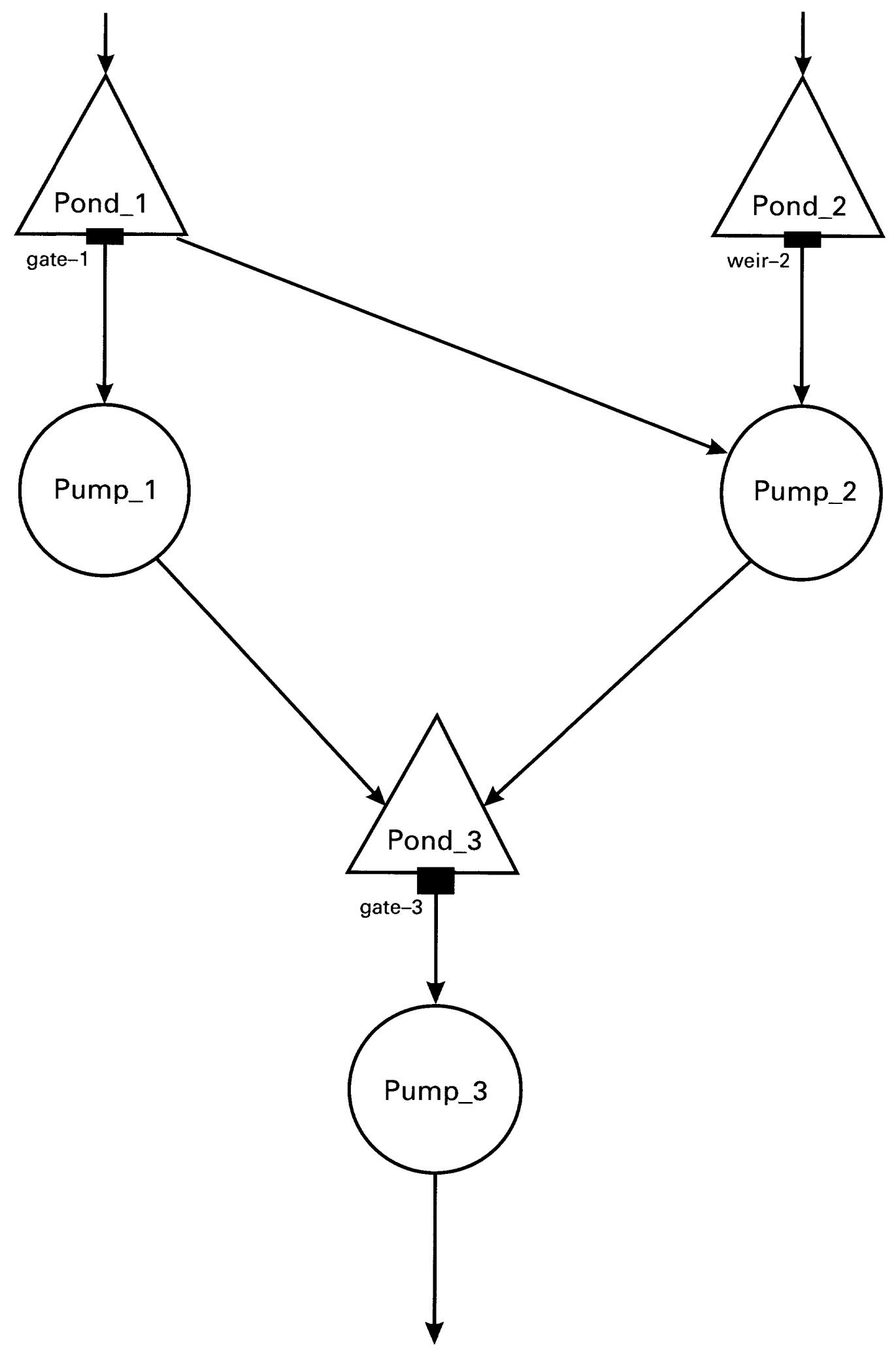

Figure 17. Network representation of flow system for sample problem. 


\section{Pond Rule-Curve and Zoning File (pdzn.dat)}

Storages of pond_1 and pond_2 are divided into two storage zones (lower zone and upper zone). However, the storage of pond_3 is divided into three zones (lower zone, upper zone, and extended upper zone). The rule curves for the three ponds are located at the top of the lower zones. Pond-bottom hydraulic data also are included in this data file. It is noted that units of storage zone, rule curve, and initial storage must be the same. The units can be either feet or acre-feet and are specified in the unit code.

\begin{tabular}{|c|c|c|c|c|}
\hline & \multirow[t]{2}{*}{ on } & \multicolumn{3}{|c|}{ rule curve and zoning. } \\
\hline & & $\begin{array}{l}\text { Initial } \\
\text { (feet) }\end{array}$ & $\begin{array}{r}\text { elevation } \\
\text { (feet) }\end{array}$ & $\begin{array}{l}\text { cond. } \\
\text { ( } f t / d)\end{array}$ \\
\hline & - & $-D_{-1}$ & $\ldots$ & . \\
\hline or & 0 & 127 & 12 & 0 . \\
\hline POND_2 & 0 & 1350.50 & 13 & 0.0001 \\
\hline POND_3 & 0 & 1039.00 & 1010.0 & 0.0001 \\
\hline
\end{tabular}

\begin{tabular}{rrr}
$\begin{array}{c}\text { Bottom } \\
\text { thickness } \\
\text { (feet) }\end{array}$ & $\begin{array}{r}\text { Rule-curve } \\
\text { elev. } \\
\text { (feet) }\end{array}$ & $\begin{array}{r}\text { zone_1 } \\
\text { elev. } \\
\text { (feet) }\end{array}$ \\
\hline 1.0 & 1274.00 & 1240.00 \\
1.0 & 1350.50 & 1320.00 \\
1.0 & 1039.00 & 1020.00
\end{tabular}

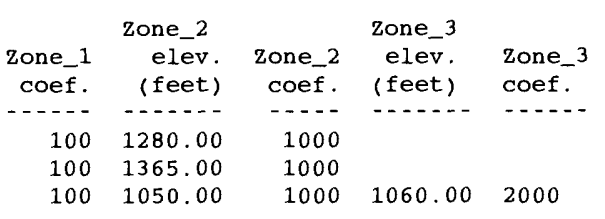

\section{Network Flow Configuration File (ntwk.dat)}

There are three flow zones from pond_1 node to pump_1 node. Canal-routing coefficients, seepage coefficients, and water-surface-evaporation coefficients also are included in this file.

\begin{tabular}{|c|c|c|c|c|c|c|c|c|c|}
\hline F_node & T_node & $\begin{array}{c}\text { Lower } \\
\text { boundary } \\
\text { (ft^3/s) }\end{array}$ & $\begin{array}{l}\text { Upper } \\
\text { boundary } \\
\text { (ft^3/s) }\end{array}$ & $\begin{array}{l}\text { Cost } \\
\text { coef. }\end{array}$ & $\begin{array}{l}\text { Initial } \\
\text { storage } \\
\text { (acre-ft) }\end{array}$ & $\begin{array}{l}\text { Trave1 } \\
\text { time } \\
\text { (day) }\end{array}$ & $\begin{array}{l}\text { Weight } \\
\text { factor }\end{array}$ & $\begin{array}{l}\text { Seepage } \\
\text { coef. }\end{array}$ & $\begin{array}{l}\text { Evap. } \\
\text { coef. } \\
(\text { in } / d)\end{array}$ \\
\hline$---\cdots$ & ---- & ------ & ------- & ---- & ------- & $-\ldots-$ & ------ & $--\cdots--$ & --- \\
\hline pond_1 & PUMP_1 & 0 . & 16000 . & 10 & 0.0 & 1 & 0.2 & 0.01 & 0.0 \\
\hline pond_1 & PUMP_2 & 0 . & 16000. & 100 & 0.0 & 1 & 0.2 & 0.01 & 0.0 \\
\hline POND_2 & PUMP_2 & 0 . & 16000. & 10 & 0.0 & 1 & 0.2 & 0.01 & 0.0 \\
\hline POND_3 & PUMP _ 3 & 0 . & 16000 . & 10 & 0.0 & 1 & 0.2 & 0.01 & 0.0 \\
\hline PUMP_1 & POND_3 & 10.0 & 16000. & 10 & 0.0 & 1 & 0.2 & -0.01 & -1.0 \\
\hline PUMP_2 & POND_3 & 10.0 & 16000. & 10 & 0.0 & 1 & 0.2 & 0.01 & 0.0 \\
\hline PUMP_3 & sksc & 10.0 & 16000 . & 10 & & & & & \\
\hline
\end{tabular}

\section{Canal Geometry Data File (geom.dat)}

Canal geometry data are used for estimating water-surface evaporation and water depth of a selected canal.

\begin{tabular}{|c|c|c|c|c|c|c|c|c|c|c|}
\hline F-Node & T-Node & $\begin{array}{l}\text { Rough. } \\
\text { coef. }\end{array}$ & $\begin{array}{r}\text { Canal } \\
\text { length } \\
\text { (feet) }\end{array}$ & $\begin{array}{l}\text { Channel } \\
\text { slope }\end{array}$ & $\begin{array}{r}\text { Cana1 } \\
\text { width } \\
\text { (feet) }\end{array}$ & $\begin{array}{l}\text { Side } \\
\text { s lope }\end{array}$ & $\begin{array}{l}\text { Canal } \\
\text { depth } \\
\text { (feet) }\end{array}$ & $\begin{array}{l}\text { Hydr. } \\
\text { cond. } \\
\text { (ft/d) }\end{array}$ & $\begin{array}{l}\text { Riverbed } \\
\text { thickness } \\
\text { (feet) }\end{array}$ & $\begin{array}{l}\text { Bottom } \\
\text { elevation } \\
\text { (feet) }\end{array}$ \\
\hline$-\cdots$ & $-\cdots--$ & - & $-\cdots$ & $-\cdots$ & - - - - & $\cdots$ & $\cdots$ & 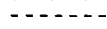 & $\cdots$ & $-\cdots$ \\
\hline pond_1 & pump_1 & 0.025 & 1000 & 0.01 & 50 & 0 & 15 & 1.0 & 1.0 & 1240.0 \\
\hline pump_1 & pond_3 & 0.025 & 5000 & 0.001 & 50 & 0 & 10 & 1.0 & 1.0 & 1140.0 \\
\hline pump_2 & pond_3 & 0.025 & 500 & 0.01 & 50 & 0 & 30 & 1.0 & 1.0 & 1140.0 \\
\hline
\end{tabular}

\section{Outlet Hydraulic-Structure File (hydr.dat)}

Three kinds of hydraulic structures - sharp-crested weir, gate on spillway, and gate on broad-crested weir-are include in the sample problem.

\begin{tabular}{|c|c|c|c|c|c|c|c|}
\hline Name & F_Node & T_Node & Type & $\begin{array}{l}\text { Base } \\
\text { elevation } \\
\text { (feet) }\end{array}$ & $\begin{array}{l}\text { Weir length or } \\
\text { pipe diameter } \\
\text { (feet) }\end{array}$ & $\begin{array}{l}\text { Weir height or } \\
\text { pipe length } \\
\text { (feet) }\end{array}$ & $\begin{array}{l}\text { Gate opening or } \\
\text { pipe friction } \\
\text { (feet) }\end{array}$ \\
\hline & & & $\ldots .$. & $\cdots-\cdots--$ & $-\cdots---1$ & $-\cdots--1$ & $\cdots$ \\
\hline Gate-1 & Pond_1 & Pump_1 & 2 & 1240.00 & 2.0 & 0 & 1.0 \\
\hline Weir-2 & Pond_2 & Pump_2 & 1 & 1340.00 & 2.0 & -20 & \\
\hline Gate-3 & Pond_3 & Pump_3 & 3 & 1020.00 & 10.0 & 0 & \\
\hline
\end{tabular}




\section{Surface-Runoff File (rnof.dat)}

\begin{tabular}{|c|c|c|c|c|c|}
\hline $\begin{array}{l}\text { Name } \\
.\end{array}$ & $\begin{array}{l}\text { Antecedent 5- } \\
\text { day rainfall } \\
\text { (inches) }\end{array}$ & $\begin{array}{l}\text { AMC for dry } \\
\text { conditions } \\
\text { (inches) }\end{array}$ & $\begin{array}{l}\text { AMC for wet } \\
\text { conditions } \\
\text { (inches) }\end{array}$ & $\begin{array}{l}\text { ScS } \\
\text { curve } \\
\text { number }\end{array}$ & $\begin{array}{l}\text { Drainage } \\
\text { area } \\
\text { (acres) }\end{array}$ \\
\hline pump_3 & 1.0 & 0.5 & 1.1 & 85 & 10000 \\
\hline
\end{tabular}

\section{Elevation-Volume-Area Relation File (pzva.dat)}

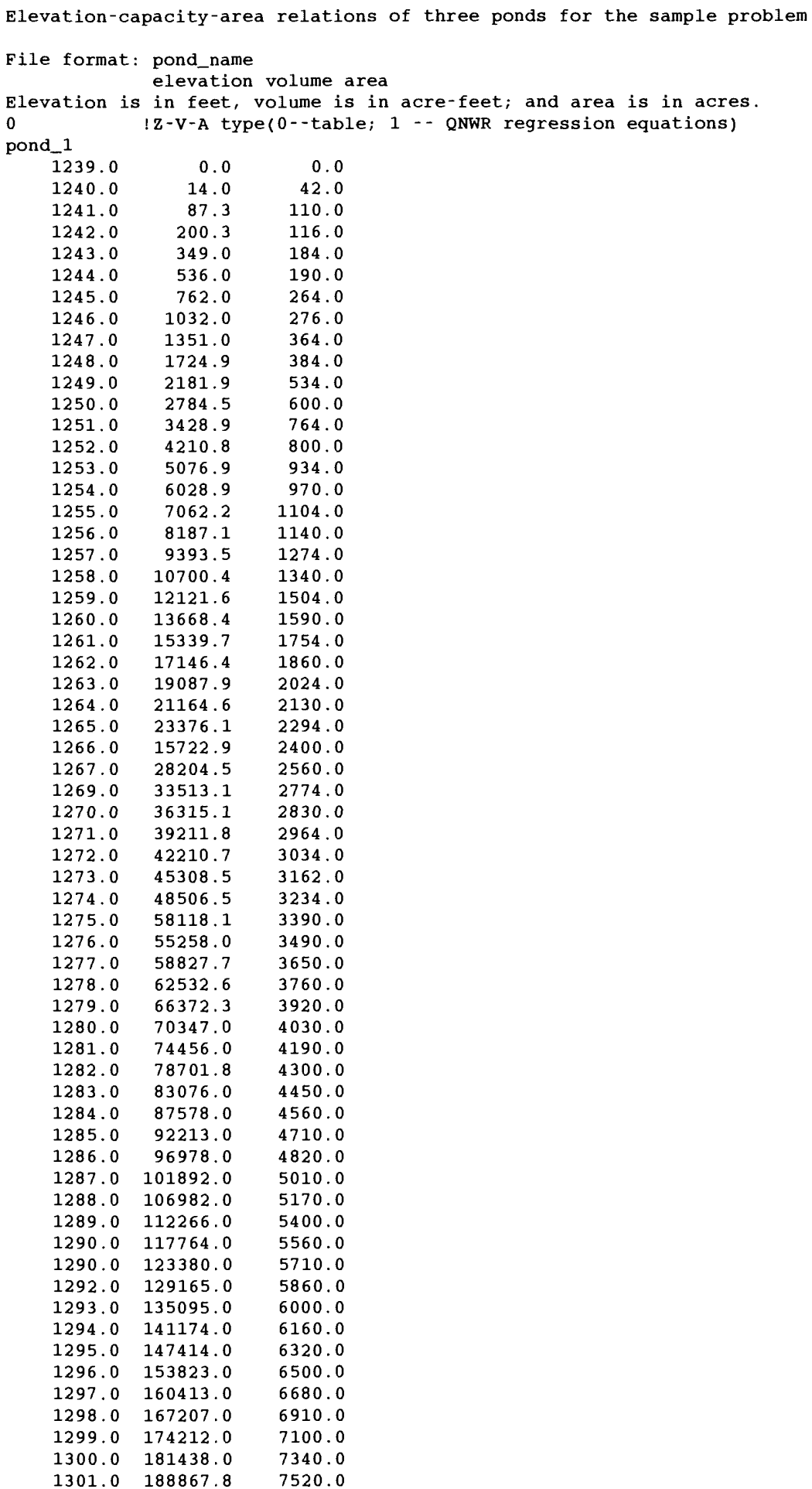




$\begin{array}{lll}1302.0 & 196507.5 & 7760.0 \\ 1303.0 & 204347.0 & 7920.0 \\ 1304.0 & 212397.0 & 8228.0 \\ 1305.0 & 220656.8 & 8340.0 \\ 1306.0 & 229126.0 & 8600.0 \\ 1307.0 & 237831.3 & 8810.0 \\ 1308.0 & 246776.0 & 9080.0 \\ 1309.0 & 255960.0 & 9290.0 \\ 1310.0 & 265405.8 & 9601.0\end{array}$

pond_2

$1308.0 \quad 0.0 \quad 0.0$

$1309.0 \quad 1.0 \quad 3.0$

$\begin{array}{lll}1310.0 & 4.5 & 4.0\end{array}$

$\begin{array}{rrr}1311.0 & 9.0 & 5.0\end{array}$

$\begin{array}{lll}1312.0 & 14.5 & 6.0\end{array}$

$\begin{array}{lll}1313.0 & 21.4 & 8.0\end{array}$

$\begin{array}{lll}1314.0 & 31.4 & 12.0\end{array}$

$1315.0 \quad 45.3 \quad 16.0$

$1316.0 \quad 64.3 \quad 22.0$

$1317.0 \quad 93.0 \quad 36.0$

$1318.0 \quad 142.3 \quad 64.0$

$\begin{array}{lll}1319.0 & 227.3 & 108.0\end{array}$

$1320.0 \quad 363.3 \quad 166.0$

$1321.0 \quad 567.1 \quad 244.0$

$1322.0 \quad 853.0 \quad 330.0$

$\begin{array}{lll}1323.0 & 1240.5 & 448.0\end{array}$

$1324.0 \quad 1744.4 \quad 562.0$

$\begin{array}{lll}1325.0 & 2384.7 & 722.0\end{array}$

$1326.0 \quad 3175.7 \quad 862.0$

$1327.0 \quad 4137.9 \quad 1066.0$

$1328.0 \quad 5271.2 \quad 1202.0$

$1329.0 \quad 6573.9 \quad 1406.0$

$\begin{array}{lll}1330.0 & 8037.5 & 1522.0\end{array}$

$1331.0 \quad 9660.4 \quad 1726.0$

$1332.0 \quad 11451.0 \quad 1856.0$

$1333.0 \quad 13419.0 \quad 2082.0$

$1334.0 \quad 15561.7 \quad 2204.0$

$1335.0 \quad 17898.0 \quad 2472.0$

$1336.0 \quad 20442.1 \quad 2616.0$

$1337.0 \quad 23199.8 \quad 2902.0$

$1338.0 \quad 26183.4 \quad 3066.0$

$1339.0 \quad 29401.2 \quad 3372.0$

$1340.0 \quad 32865.8 \quad 3558.0$

$1341.0 \quad 36583.7 \quad 3880.0$

$\begin{array}{lll}1342.0 & 40528.5 & 4010.0\end{array}$

$1343.0 \quad 44707.3 \quad 4350.0$

$1344.0 \quad 49103.2 \quad 4442.0$

$1345.0 \quad 53730.0 \quad 4814.0$

$\begin{array}{lll}1346.0 & 58594.9 & 4916.0\end{array}$

$1347.0 \quad 63712.6 \quad 5322.0$

$1348.0 \quad 69090.5 \quad 5434.0$

$1349.0 \quad 74733.2 \quad 5854.0$

$1350.0 \quad 80864.1 \quad 5976.0$

$\begin{array}{lll}1351.0 & 86849.7 & 6430.0\end{array}$

$1352.0 \quad 93343.6 \quad 6558.0$

$1353.0 \quad 100140.2 \quad 7038.0$

$1354.0 \quad 107256.0 \quad 7094.0$

$1355.0 \quad 114710.5 \quad 7718.0$

$1356.0 \quad 122532.2 \quad 7926.0$

$\begin{array}{lll}1357.0 & 130752.5 & 8518.0\end{array}$

$1358.0 \quad 139402.1 \quad 8782.0$

$1359.0 \quad 148449.8 \quad 9316.0$

$1360.0 \quad 157889.5 \quad 9584.0$

$1361.0 \quad 167748.3 \quad 10116.0$

$1362.0 \quad 178022.9 \quad 10434.0$

$1363.0 \quad 188741.0 \quad 11006.0$

$1364.0 \quad 199911.2 \quad 11334.0$

$1365.0 \quad 211534.5 \quad 11915.0$

$1366.0 \quad 223636.1 \quad 12249.0$

pond_3

$1008.0 \quad 0.0 \quad 0.0$

$\begin{array}{lll}1009.0 & 0.0 & 0.0\end{array}$

$\begin{array}{lll}1010.0 & 3.0 & 8.4\end{array}$

$\begin{array}{lll}1011.0 & 20.0 & 27.4\end{array}$

$\begin{array}{lll}1012.0 & 50.0 & 32.7\end{array}$

$1013.0 \quad 84.0 \quad 35.3$

$\begin{array}{lll}1014.0 & 122.0 & 40.8\end{array}$

$1015.0 \quad 164.0 \quad 43.3$

$1016.0 \quad 212.0 \quad 52.9$

$1017.0 \quad 269.0 \quad 61.2$ 


\begin{tabular}{|c|c|c|}
\hline 8.0 & 335.0 & 70.9 \\
\hline 1019.0 & 411.0 & 81.2 \\
\hline 020.0 & 505.0 & 107.4 \\
\hline 021.0 & 666.0 & 221.4 \\
\hline 1022.0 & 966.0 & 386.2 \\
\hline 1023.0 & 1451.0 & 591.0 \\
\hline 1024.0 & 2171.0 & 857.2 \\
\hline 1025.0 & 3167.0 & 1141.5 \\
\hline 1026.0 & 4467.0 & 1465.2 \\
\hline 1027.0 & 6089.0 & 1784.1 \\
\hline 1028.0 & 8054.0 & 2151.7 \\
\hline 1029.0 & 10517.0 & 2788.0 \\
\hline 1030.0 & 13576.0 & 3338.2 \\
\hline 1031.0 & 17332.0 & 4189.9 \\
\hline 1032.0 & 21788.0 & 4727.5 \\
\hline 1033.0 & 27038.0 & 5790.4 \\
\hline 1034.0 & 32947.0 & 6028.4 \\
\hline 1036.0 & 46511.0 & 7193.9 \\
\hline 037.0 & 54164.0 & 8125.5 \\
\hline .0 & 62433.0 & 8417.4 \\
\hline 039.0 & 71284.0 & 9291.8 \\
\hline 40.0 & 80723.0 & 9587.0 \\
\hline 1041.0 & 90745.0 & 10463.4 \\
\hline 1042.0 & 101314.0 & 10795.4 \\
\hline 1043.0 & 112626.0 & 1714.8 \\
\hline 1044.0 & 12452 & 2084.1 \\
\hline 1045.0 & 137072.0 & 13015.6 \\
\hline 1046.0 & 150271.0 & 13383.2 \\
\hline 1047.0 & 164118.0 & 4316.0 \\
\hline 1048.0 & 178617.0 & 4682.8 \\
\hline 104 & 193774.0 & 5636.2 \\
\hline .0 & 2096 & 22.6 \\
\hline .0 & 226110.0 & 16996.2 \\
\hline 105 & 243309.0 & 7402.6 \\
\hline 1053.0 & 261221.0 & 8426.3 \\
\hline 1054.0 & 279875.0 & 8882.6 \\
\hline 1055.0 & 299292.0 & 9956.3 \\
\hline .0 & 5.0 & 50.7 \\
\hline 105 & 340497.0 & 58.2 \\
\hline 1058.0 & 362316.0 & 2080.9 \\
\hline 1059.0 & 384963.0 & 3217.9 \\
\hline 1060.0 & 408461.0 & 3779.2 \\
\hline 1061.0 & 432828.0 & 24959.5 \\
\hline 106 & 7.0 & 59.6 \\
\hline 1063.0 & 484273.0 & 26817.4 \\
\hline 1064.0 & 514131.0 & 27500.0 \\
\hline 1065.0 & 539588.0 & 8819.1 \\
\hline 1066.0 & 568766.0 & 29538.4 \\
\hline 1067.0 & 598982.0 & 30898.7 \\
\hline .0 & 930250.0 & 31638.7 \\
\hline 1069.0 & 662487.0 & 32839.0 \\
\hline 1070.0 & 695834.0 & 33857.6 \\
\hline 1071.0 & 730152.0 & 34780.5 \\
\hline 1073.0 & 802016.0 & 36862.2 \\
\hline 1074.0 & 839592.0 & 38294.3 \\
\hline 1075.0 & 878315.0 & 39153.3 \\
\hline 1076.0 & 918206.0 & 40633.3 \\
\hline 1077.0 & 959294.0 & 41544.4 \\
\hline 1078.0 & 1001594.0 & 43063.0 \\
\hline 1079.0 & 1045132.0 & 44017.6 \\
\hline 1080.0 & 1089926.0 & 45574.9 \\
\hline
\end{tabular}

FINISH

\section{Seasonal Target Water-Demand File (tws.dat)}

Seasonal water demands for the sample problem (values are in acre-feet.

$$
\begin{aligned}
& > \\
& > \\
& 0
\end{aligned}
$$

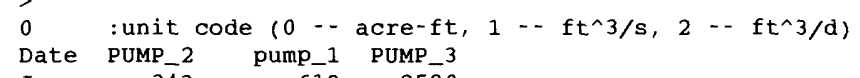$$
\begin{array}{lrrr}
\text { Jan. } & 343 & 619 & 2580
\end{array}
$$$$
\begin{array}{llll}
\text { Jan. } & 343 & 619 & 2580 \\
\text { Feb. } & 310 & 599 & 2330
\end{array}
$$$$
\text { March } \quad 343 \quad 619 \quad 2580
$$$$
\text { April } \quad 332 \quad 599 \quad 2496
$$$$
\begin{array}{llll}
\text { May } & 343 & 619 & 2580
\end{array}
$$

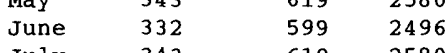$$
\text { July } \quad 343 \quad 619 \quad 2580
$$ 


$\begin{array}{llll}\text { Aug. } & 343 & 619 & 2580 \\ \text { Sept. } & 332 & 599 & 2496 \\ \text { Oct. } & 343 & 619 & 2580 \\ \text { Nov. } & 332 & 599 & 2496 \\ \text { Dec. } & 343 & 619 & 2580\end{array}$

\section{Seasonal Water-Surface-Evaporation Coefficient File (pet.dat)}

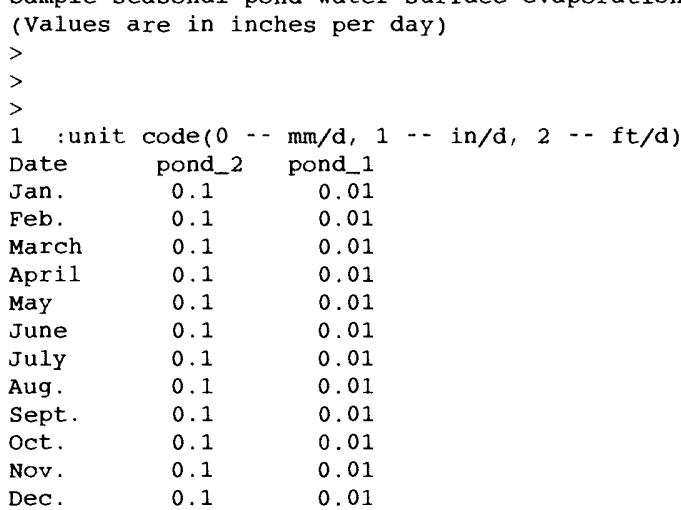

\section{Seasonal Rule-Curve File (rc.dat)}

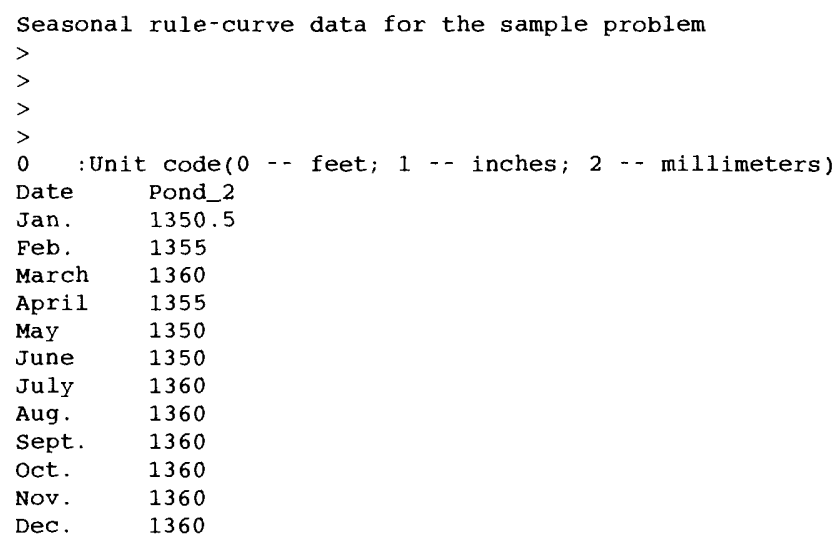

\section{Local Net Inflow File (ifw.dat)}

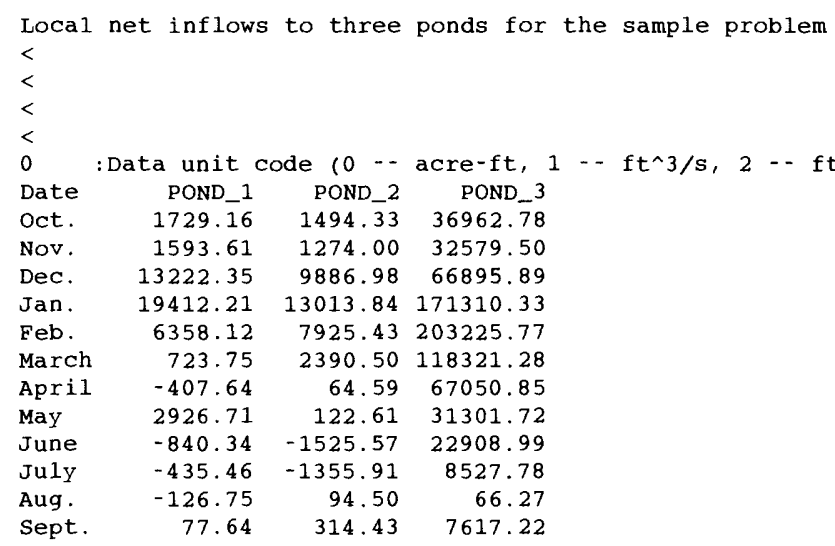




\section{Precipitation File (rain.dat)}

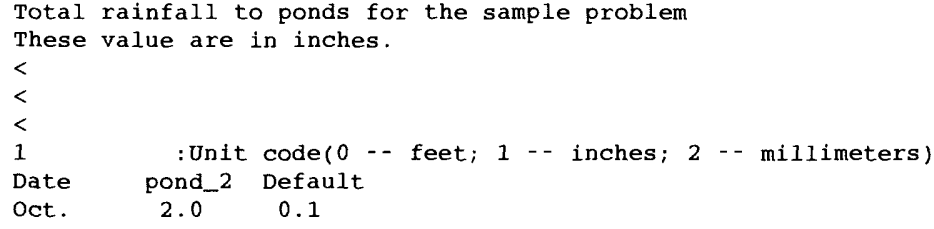

File for Time-Dependent, Water-Surface-Evaporation Coefficients (pet2.dat)

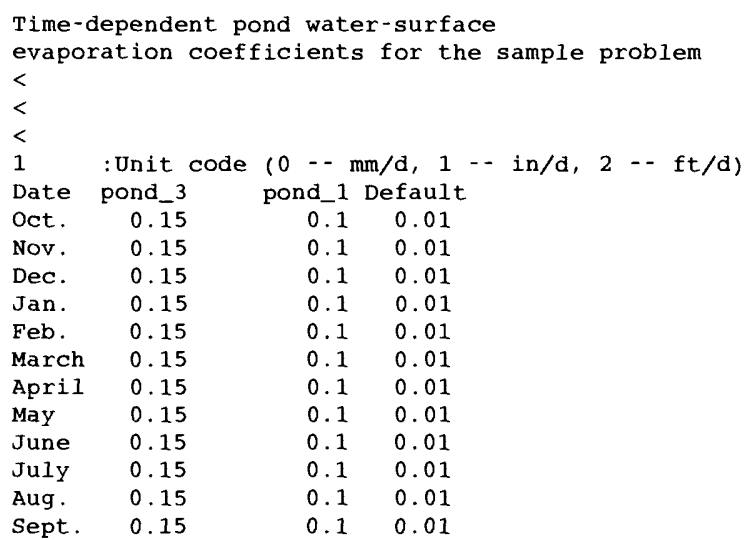

\section{File for Time-Dependent, Target Water Demands (tws2.dat)}

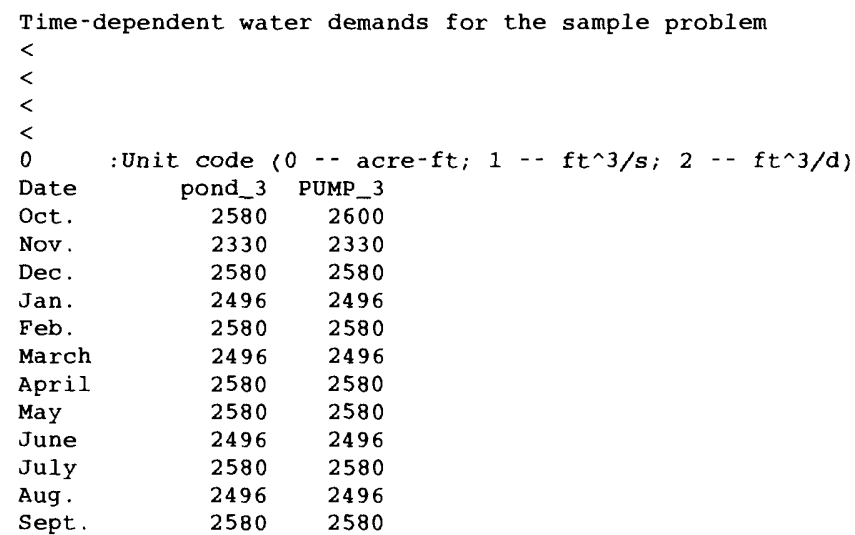

File for Time-Dependent, Pond Rule Curves (rc2.dat)

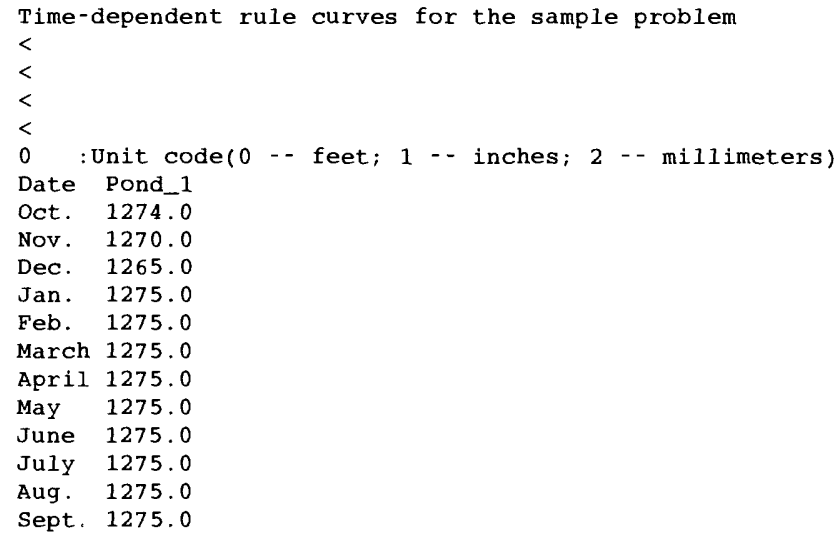




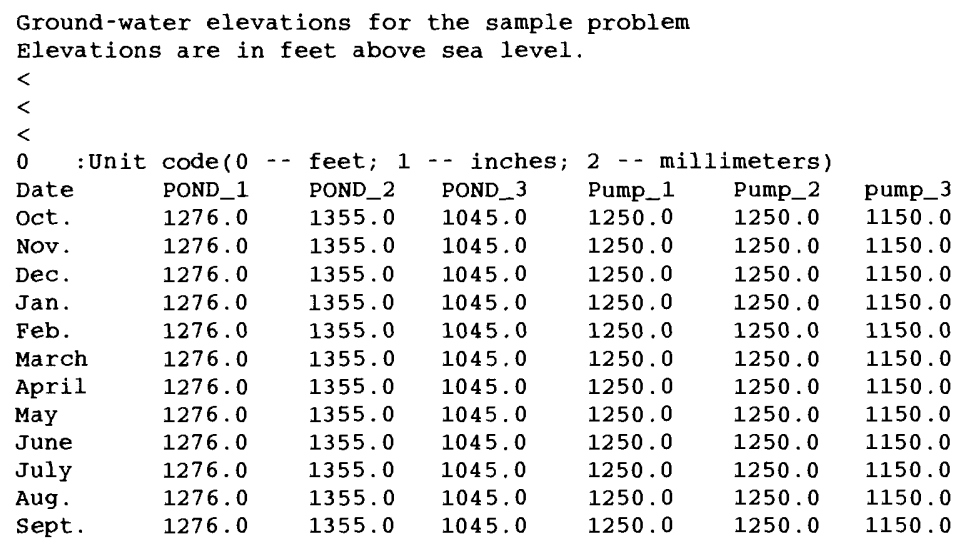

\section{File for List of Nodes for Time-Series Water-Budget Output (snbl.dat)}

This file is used to list nodes for which the time-series output of water budgets is needed. For each node specified, two output files are generated—one for nodal water budget (for example, bpond_1.out) and the other for water releases to downstream nodes (for example, rpond_1.out).

pond_1

pond_2

pond_3

pump_1

pump_2

pump_3

\section{File for List of Canals for Water-Budget Output (sabl.dat)}

This file is used to list canal reaches for which time-series output of water budgets is needed. In this sample problem, only three canals are listed for the time-series output of water budgets. The names of output files are automatically generated from the OPONDS program with the form arbud\#\#\#.dat, where \#\#\# is the sequential number such as 001,002 , and 003 in the list file. For example, the output file name for canal reach from pond_1 to pump_1 is arbud001.dat.

pond_1 pump_1

pond_2 pump_2

pump_1 pond_3

\section{Sample Problem Output}

Four general output files are generated from the OPONDS program for the sample problem. The first one is for the input information and network configuration, the second one is for nodal water budgets, the third one is for canal water budgets, and the final one is for hydraulic-structure operations. The output file names are specified in the master data file. In additional to general outputs, there are two kinds of optional water-budget outputs in time-series format for specified nodes and canal reaches. It should not be expected that the outputs from running the same problem on different computers will match exactly. Small variations in output can be caused by differences in the way real numbers are stored and calculated. Storage and calculation of real numbers depend on the specific computer hardware, the FORTRAN compiler, and the math library that is loaded with the compiled program. Output variations among computers also depend on the size of the problem, the number of iterations required for solution, and the precision used when printing results. 


\section{Output File for input information and Network Configuration (nsim.out)}

Operation of a river system.

Summary of simulation period:

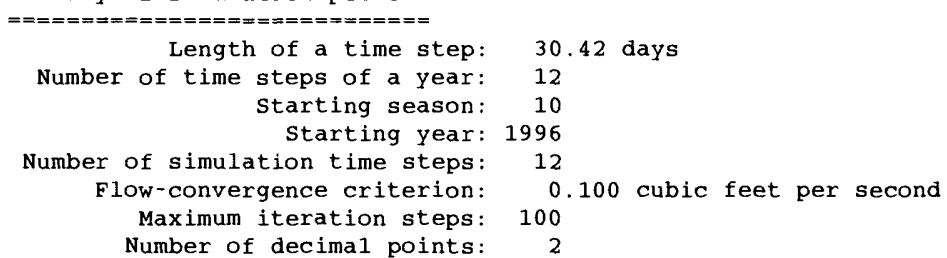

Summary of pond elevation-volume-area relations:

\begin{tabular}{|c|c|c|c|c|}
\hline No & Name & $\begin{array}{r}\text { Number of } \\
\text { records }\end{array}$ & $\begin{array}{r}\text { Minimum } \\
\text { elevation } \\
\text { (feet) }\end{array}$ & $\begin{array}{c}\text { Maximum } \\
\text { elevation } \\
\text { (feet) }\end{array}$ \\
\hline-- & 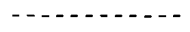 & $\cdots-\cdots$ & $\ldots \ldots$ & 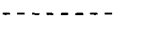 \\
\hline 1 & POND_1 & 71 & 1239.00 & 1310.00 \\
\hline 2 & POND_2 2 & 59 & 1308.00 & 1366.00 \\
\hline 3 & POND_3 & 71 & 1008.00 & 1080.00 \\
\hline
\end{tabular}

Part 1: Pond-storage zoning information

\begin{tabular}{|c|c|c|c|c|}
\hline \multirow[t]{4}{*}{ POND_1 } & & 1 & \multirow{4}{*}{1.00} & : Pond name and corresponding node number \\
\hline & 1239.00 & 0.00 & & : Bottom elevation, hydraulic conductivity, and thickness \\
\hline & $\begin{array}{r}48506.50 \\
1274.00\end{array}$ & & & $\begin{array}{l}\text { Initial storage, in acre-feet } \\
\text { : Rule-curve elevation, in feet }\end{array}$ \\
\hline & 1274.00 & & & : Rule-curve elevation, in feet \\
\hline 1 & 1240.00 & 100 & & :Zone number, elevation, and penalty coefficient \\
\hline 2 & 1280.00 & 1000 & & : Zone number, elevation, and penalty coefficient \\
\hline \multirow[t]{4}{*}{ POND_2 } & & 2 & & : Pond name and corresponding node number \\
\hline & 1308.00 & 0.00 & 1.00 & :Bottom elevation, hydraulic conductivity, and thickness \\
\hline & 83856.91 & & & Initial storage, in acre-feet \\
\hline & 1350.50 & & & :Rule-curve elevation, in feet \\
\hline 1 & 1320.00 & 100 & & : Zone number, elevation, and penalty coefficient \\
\hline 2 & 1365.00 & 1000 & & : Zone number, elevation, and penalty coefficient \\
\hline \multirow[t]{4}{*}{ POND_3 } & & 3 & & : Pond name and corresponding node number \\
\hline & 1010.00 & 0.00 & 1.00 & :Bottom elevation, hydraulic conductivity, and thickness \\
\hline & 71284.00 & & & Initial storage, in acre-feet \\
\hline & 1039.00 & & & : Rule-curve elevation, in feet \\
\hline 1 & 1020.00 & 100 & & : Zone number, elevation, and penalty coefficient \\
\hline 2 & 1050.00 & 1000 & & : Zone number, elevation, and penalty coefficient \\
\hline 3 & 1060.00 & 2000 & & : Zone number, elevation, and penalty coefficient \\
\hline
\end{tabular}

Part 2: Network flow configuration

\begin{tabular}{|c|c|c|c|c|c|c|c|c|c|}
\hline & & $\begin{array}{r}\text { Lower } \\
\text { boundary } \\
\text { (cubic feet } \\
\text { per second) }\end{array}$ & $\begin{array}{c}\text { Upper } \\
\text { boundary } \\
\text { (cubic feet } \\
\text { per second) }\end{array}$ & $\begin{array}{l}\text { Penalty } \\
\text { coefficient }\end{array}$ & $\begin{array}{c}\text { Initial } \\
\text { storage } \\
\text { (acre- } \\
\text { feet) }\end{array}$ & $\begin{array}{c}\text { Travel - } \\
\text { time } \\
\text { (day) }\end{array}$ & $\begin{array}{l}\text { Weighting } \\
\text { factor }\end{array}$ & $\begin{array}{l}\text { Seepage } \\
\text { coefficient }\end{array}$ & $\begin{array}{l}\text { Evaporation } \\
\text { coefficient } \\
\text { (inches } \\
\text { per day) }\end{array}$ \\
\hline POND_1 & PUMP_1 & 0.00 & 16000.00 & 10 & 0.00 & 1.00 & 0.20 & 0.01 & 0.00 \\
\hline POND_1 & PUMP_2 & 0.00 & 16000.00 & 100 & 0.00 & 1.00 & 0.20 & 0.01 & 0.00 \\
\hline POND_2 & PUMP_2 & 0.00 & 16000.00 & 10 & 0.00 & 1.00 & 0.20 & 0.01 & 0.00 \\
\hline PUMP_1 & POND_3 & 10.00 & 16000.00 & 10 & 0.00 & 1.00 & 0.20 & -0.01 & -1.00 \\
\hline PUMP_2 & POND_3 & 10.00 & 16000.00 & 10 & 0.00 & 1,00 & 0.20 & 0.01 & 0.00 \\
\hline
\end{tabular}

PART 3: Canal geometry data

\begin{tabular}{|c|c|c|c|c|c|c|c|c|c|c|}
\hline & & & Canal & & Bottom & & Canal & $\begin{array}{l}\text { Riverbed } \\
\text { hydraulic } \\
\text { conductivity }\end{array}$ & Riverbed & Entry \\
\hline $\begin{array}{l}\text { F-node } \\
\text { name }\end{array}$ & $\begin{array}{l}\mathrm{T} \text {-node } \\
\text { name }\end{array}$ & $\begin{array}{l}\text { Roughness } \\
\text { coefficient }\end{array}$ & $\begin{array}{l}\text { length } \\
\text { (feet) }\end{array}$ & $\begin{array}{l}\text { Canal } \\
\text { slope }\end{array}$ & $\begin{array}{l}\text { width } \\
\text { (feet) }\end{array}$ & $\begin{array}{l}\text { side } \\
\text { slope }\end{array}$ & $\begin{array}{l}\text { depth } \\
\text { (feet) }\end{array}$ & $\begin{array}{l}\text { (feet } \\
\text { per day) }\end{array}$ & $\begin{array}{l}\text { thickness } \\
\text { (feet) }\end{array}$ & $\begin{array}{l}\text { elevation } \\
\text { (feet) }\end{array}$ \\
\hline---- & $\cdots$ & -------- & ------- & ------- & ------ & ------- & $\cdots-----$ & $\cdots--\cdots$ & $-\cdots-\cdots$ & $--\cdots-\cdots$ \\
\hline POND_1 & PUMP_1 & 0.0250 & 1000.00 & 0.010000 & 50.00 & 0.000000 & 15.00 & 1.00 & 1.00 & 1240.00 \\
\hline PUMP_1 & POND_3 & 0.0250 & 5000.00 & 0.001000 & 50.00 & 0.000000 & 10.00 & 1.00 & 1.00 & 1140.00 \\
\hline PUMP_2 & POND_3 & 0.0250 & 500.00 & 0.010000 & 50.00 & 0.000000 & 30.00 & 1.00 & 1.00 & 1140.00 \\
\hline
\end{tabular}




\begin{tabular}{|c|c|c|c|c|c|c|c|c|}
\hline \multirow{3}{*}{$\begin{array}{l}\text { Structure } \\
\text { name } \\
----\end{array}$} & \multirow{3}{*}{$\begin{array}{l}F \text {-node } \\
\text { name } \\
----\end{array}$} & \multirow{3}{*}{$\begin{array}{l}\mathrm{T} \text {-node } \\
\text { name } \\
----\end{array}$} & \multirow{3}{*}{$\begin{array}{l}\text { Structure } \\
\text { type }\end{array}$} & \multirow{3}{*}{$\begin{array}{c}\text { Base } \\
\text { elevation } \\
\text { (feet) }\end{array}$} & \multirow{2}{*}{$\begin{array}{l}\text { Weir } \\
\text { width } \\
\text { or pipe } \\
\text { diameter } \\
\text { (feet) }\end{array}$} & \multirow{2}{*}{$\begin{array}{l}\text { Weir } \\
\text { height } \\
\text { or pipe } \\
\text { length } \\
\text { (feet) }\end{array}$} & \multirow[b]{2}{*}{$\begin{array}{l}\text { Pipe- } \\
\text { friction } \\
\text { factor }\end{array}$} & \multirow[b]{2}{*}{$\begin{array}{r}\text { Pipe- } \\
\text { entry loss } \\
\text { factor }\end{array}$} \\
\hline & & & & & & & & \\
\hline & & & & & $-\cdots-\cdots$ & 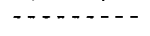 & $--\cdots---$ & $-\cdots-\cdots$ \\
\hline Gate-1 & Pond_1 & Pump_1 & Gate spillway & 1240.00 & 2.00 & 0.00 & 1.00000 & 0.00000 \\
\hline Weir-2 & Pond_2 & Pump_2 & Sharp-crested weir & 1340.00 & 2.00 & -20.00 & 0.00000 & 0.00000 \\
\hline Gate-3 & Pond_3 & Pump_3 & sluice gate & 1020.00 & 10.00 & 0.00 & 0.00000 & 0.00000 \\
\hline
\end{tabular}

Part 5: Surface-runoff data

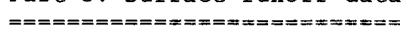

Initial criterion 5 -day rainfal1

\begin{tabular}{|c|c|c|c|c|}
\hline $\begin{array}{r}\text { Antecedent } \\
\text { 5-day rainfa11 } \\
\text { (inches) }\end{array}$ & $\begin{array}{r}\text { Dry } \\
\text { condition } \\
\text { (inches) }\end{array}$ & $\begin{array}{r}\text { wet } \\
\text { condition } \\
\text { (inches) }\end{array}$ & $\begin{array}{r}\text { SCS } \\
\text { curve } \\
\text { number }\end{array}$ & $\begin{array}{r}\text { Drainage } \\
\text { area } \\
\text { (acres) }\end{array}$ \\
\hline$\cdots+\cdots$ & $\cdots+\cdots$ & 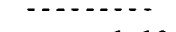 & $---\cdot-$ & -- \\
\hline 1.00 & 0.50 & 1.10 & 85.00 & 10000.00 \\
\hline
\end{tabular}

Part 10: Seasonal target water demands, in acre-feet

\begin{tabular}{|c|c|c|c|}
\hline SEASON & PUMP_2 & PUMP_1 & PUMP_3 \\
\hline 1 & 343.00 & 619.00 & 2580.00 \\
\hline 2 & 310.00 & 599.00 & 2330.00 \\
\hline 3 & 343.00 & 619.00 & 2580.00 \\
\hline 4 & 332.00 & 599.00 & 2496.00 \\
\hline 5 & 343.00 & 619.00 & 2580.00 \\
\hline 6 & 332.00 & 599.00 & 2496.00 \\
\hline 7 & 343.00 & 619.00 & 2580.00 \\
\hline 8 & 343.00 & 619.00 & 2580.00 \\
\hline 9 & 332.00 & 599.00 & 2496.00 \\
\hline 10 & 343.00 & 619.00 & 2580.00 \\
\hline 11 & 332.00 & 599.00 & 2496.00 \\
\hline 12 & 343.00 & 619.00 & 2580.00 \\
\hline
\end{tabular}

Part 11: Seasonal water-surface evaporation coefficients, in inches per day

\begin{tabular}{|c|c|c|}
\hline SEASON & POND 2 & POND 1 \\
\hline 1 & 0.10 & 0.01 \\
\hline 2 & 0.10 & 0.01 \\
\hline 3 & 0.10 & 0.01 \\
\hline 4 & 0.10 & 0.01 \\
\hline 5 & 0.10 & 0.01 \\
\hline 6 & 0.10 & 0.01 \\
\hline 7 & 0.10 & 0.01 \\
\hline 8 & 0.10 & 0.01 \\
\hline 9 & 0.10 & 0.01 \\
\hline 10 & 0.10 & 0.01 \\
\hline 11 & 0.10 & 0.01 \\
\hline 12 & 0.10 & 0.01 \\
\hline
\end{tabular}

Part 13: Seasonal rule-curve elevations, in feet

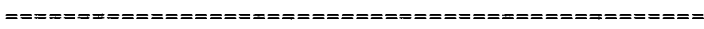

$\begin{array}{cr}\text { SEASON } & \text { POND_2 } \\ 1 & 1350.50 \\ 2 & 1355.00 \\ 3 & 1360.00 \\ 4 & 1355.00 \\ 5 & 1350.00 \\ 6 & 1350.00 \\ 7 & 1360.00 \\ 8 & 1360.00 \\ 9 & 1360.00 \\ 10 & 1360.00 \\ 11 & 1360.00 \\ 12 & 1360.00\end{array}$


Summary for local incremental inflow data file:

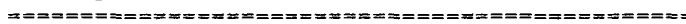

File name: ifw. dat

Data unit: acre-feet

Number of nodes: 3

Number of records: 12

List of nodal names: POND_1 POND_2 POND_3

Summary for precipitation data file:

File name: rain.dat

Data unit: inches

Number of nodes: 6

Number of records: 1

List of nodal name: POND_2 DEFAULT

Summary for water-surface evaporation coefficient data file:

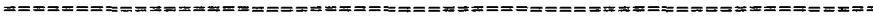

File name: pet2.dat

Data unit: inches per day

Number of nodes: 6

Number of records: 12

List of nodal name: POND_3 POND_1 DEFAULT

Summary for target water-demand data file:

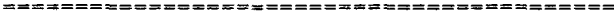

File name: tws2.dat

Data unit: acre-feet

Number of nodes: 2

Number of records: 12

List of nodal names: POND_3 PUMP_3

Summary for rule-curve elevation data file:

File name: rc2.dat

Data unit: feet

Number of nodes: 1

Number of records: 12

List of nodal names: POND 1

Summary for ground-water-level data file:

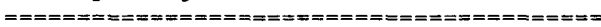

File name: gwl.dat

Data unit: feet

Number of nodes: 6

Number of records: 12

List of nodal names: POND_1 POND_2 POND_3 PUMP_1 PUMP_2 PUMP_3

Node name and type of basic network

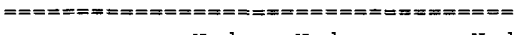

Node Node Node

number name type

-

POND 1 POND

POND_2 POND

POND_3 POND

PUMP 1 GENERAL

PUMP_2 GENERAL

PUMP_3 GENERAL 


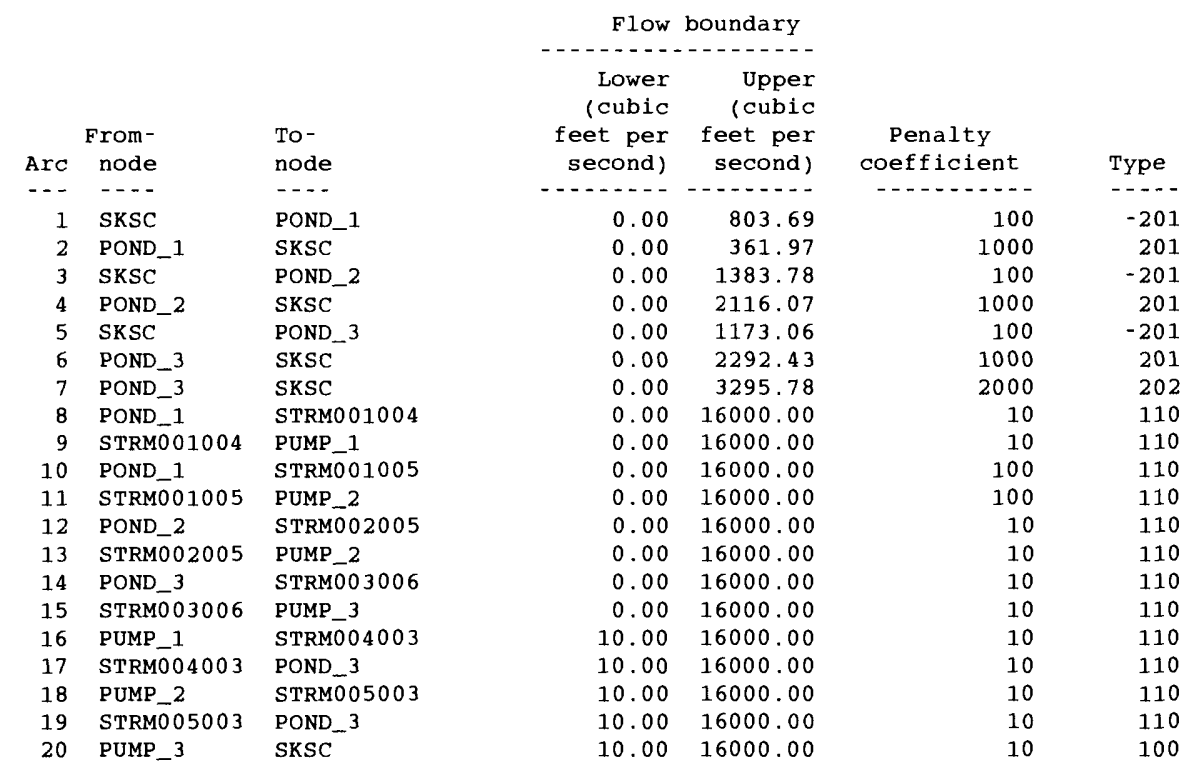

Pond-zoning penalty coefficients

$\begin{array}{lrrr} & & & \\ \text { Name } & \text { Zone 1 } & \text { Zone 2 } & \text { Zone } 3 \\ -\cdots- & 100 & 1000 & \\ \text { POND_1 } & 100 & 1000 & \\ \text { POND_2 } & 100 & 1000 & 2000 \\ \text { POND_3 } & & \end{array}$

Flow-zoning penalty coefficients

\begin{tabular}{llrrr}
$\begin{array}{l}\text { From- } \\
\text { node }\end{array}$ & $\begin{array}{l}\text { To } \\
\text { node }\end{array}$ & $\begin{array}{r}\text { Normal } \\
\text { flow } \\
\text { zone }\end{array}$ & $\begin{array}{r}\text { Lower } \\
\text { flow } \\
\text { zone }\end{array}$ & $\begin{array}{r}\text { Upper } \\
\text { flow } \\
\text { zone }\end{array}$ \\
\hline POND_1 & PUMP_1 & 10 & & \\
POND_1 & PUMP_2 & 100 & & \\
POND_2 & PUMP_2 & 10 & \\
POND_3 & PUMP_3 & 10 & \\
PUMP_1 & POND_3 & 10 & \\
PUMP_2 & POND_3 & 10 & \\
PUMP_3 & SKSC & 10 &
\end{tabular}

Nodal water budgets for whole simulation

\begin{tabular}{|c|c|c|c|c|c|c|c|c|c|c|}
\hline $\begin{array}{l}\text { Node } \\
\text { name }\end{array}$ & $\begin{array}{l}\text { Node } \\
\text { type }\end{array}$ & $\begin{array}{l}\text { Initial } \\
\text { storage } \\
\text { (acre- } \\
\text { feet) }\end{array}$ & $\begin{array}{c}\text { Upstream } \\
\text { inflow } \\
\text { (acre- } \\
\text { feet) }\end{array}$ & $\begin{array}{c}\text { Local net } \\
\text { inflow } \\
\text { (acre- } \\
\text { feet) }\end{array}$ & $\begin{array}{c}\text { Evap- } \\
\text { ration } \\
\text { (acre- } \\
\text { feet) }\end{array}$ & $\begin{array}{c}\text { Rainfall } \\
\text { (acre- } \\
\text { feet) }\end{array}$ & $\begin{array}{l}\text { Seepage } \\
\text { (acre- } \\
\text { feet) }\end{array}$ & $\begin{array}{c}\text { Withdrawal } \\
\text { (acre- } \\
\text { feet) }\end{array}$ & $\begin{array}{c}\text { Downstream } \\
\text { release } \\
\text { (acre- } \\
\text { feet) }\end{array}$ & $\begin{array}{c}\text { Final } \\
\text { storage } \\
\text { (acre- } \\
\text { feet) }\end{array}$ \\
\hline---- & $\cdots-$ & ------- & $-\cdots$ & -------- & $----\cdot-\cdots$ & $---\cdots-\cdot$ & ------- & $--\cdots---$ & $-------\infty$ & $-----\cdot--$ \\
\hline POND_1 & 1 & 48506.50 & 0.00 & 44233.36 & 9070.00 & 26.95 & 0.00 & 0.00 & 49592.00 & 34104.81 \\
\hline POND_2 & 1 & 83856.91 & 0.02 & 33699.75 & 2006.36 & 1033.83 & -730.60 & 0.00 & 42006.13 & 75308.61 \\
\hline POND_3 & 1 & .71284 .00 & 98219.99 & 766768.44 & 43382.32 & 77.43 & -1911.17 & 30374.00 & 797618.75 & 66885.85 \\
\hline PUMP_1 & 2 & 0.00 & 49056.46 & 0.00 & 0.00 & 0.00 & 0.00 & 7328.00 & 41728.46 & 0.00 \\
\hline PUMP_2 & 2 & 0.00 & 41555.05 & 0.00 & 0.00 & 0.00 & 0.00 & 4039.00 & 37516.05 & 0.00 \\
\hline PUMP_3 & 2 & 0.00 & 789537.75 & 0.00 & 0.00 & 0.00 & 0.00 & 30394.00 & 759143.75 & 0.00 \\
\hline
\end{tabular}

Canal water budgets for whole simulation

\begin{tabular}{|c|c|c|c|c|c|c|c|c|}
\hline No. & From & To & $\begin{array}{l}\text { Inflow } \\
\text { (acre- } \\
\text { feet) }\end{array}$ & $\begin{array}{r}\text { Initial } \\
\text { storage } \\
\text { (acre- } \\
\text { feet) }\end{array}$ & $\begin{array}{r}\text { Canal } \\
\text { seepage } \\
\text { (acre- } \\
\text { feet) }\end{array}$ & $\begin{array}{c}\text { Surface } \\
\text { evapo- } \\
\text { ration } \\
\text { (acre- } \\
\text { feet) }\end{array}$ & $\begin{array}{r}\text { Final } \\
\text { storage } \\
\text { (acre- } \\
\text { feet) }\end{array}$ & $\begin{array}{l}\text { Outflow } \\
\text { (acre- } \\
\text { feet) }\end{array}$ \\
\hline-- & ---- & ---- & $-\cdots----$ & $----\cdots--$ & $-\cdots-\cdots$ & $---\cdots$ & $------\cdots$ & $-\cdots--\cdot--$ \\
\hline 1 & POND_1 & PUMP_1 & 49592.00 & 1576.56 & 495.93 & 0.00 & 39.61 & 49056.46 \\
\hline 2 & POND_1 & PUMP_2 & 0.00 & 0.00 & 0.00 & 0.00 & 0.00 & 0.00 \\
\hline 3 & POND_2 & PUMP_2 & 42006.13 & 1338.02 & 420.07 & 0.00 & 31.01 & 41555.05 \\
\hline 4 & POND_3 & PUMP_3 & 797618.75 & 25902.82 & 7976.17 & 0.00 & 104.85 & 789537.75 \\
\hline 5 & PUMP_1 & POND_3 & 41728.46 & 1817.42 & -19448.18 & 13.97 & 63.69 & 61098.98 \\
\hline 6 & PUMP_2 & POND_3 & 37516.05 & 1203.05 & 375.17 & 0.00 & 19.88 & 37121.00 \\
\hline
\end{tabular}


$\begin{array}{lllllll}7 \text { PUMP_3 } & \text { SKSC } & 759143.75 & 0.00 & 0.00 & 0.00 & 0.00759143 .75\end{array}$

System water budgets

Budget

Initial storage:

Total net inflow:

Runoff:

Evaporation:

Ground-water seepage:

Water withdrawal:

outflow:

Final storage:

\begin{tabular}{rrr} 
Pond & Canal & Total \\
\hline 203647.41 & $-\ldots .-$ &..- \\
844701.56 & 0.00 & 203647.41 \\
1138.22 & 0.00 & 844701.56 \\
54458.68 & 0.00 & 1138.22 \\
-2641.76 & 13.97 & 54472.65 \\
72135.00 & -10180.84 & -12822.60 \\
0.00 & 0.00 & 72135.00 \\
176299.28 & 759143.75 & 759143.75 \\
& 259.03 & 176558.31
\end{tabular}

\section{Output File for Nodal Water Budgets (ndbt.out)}

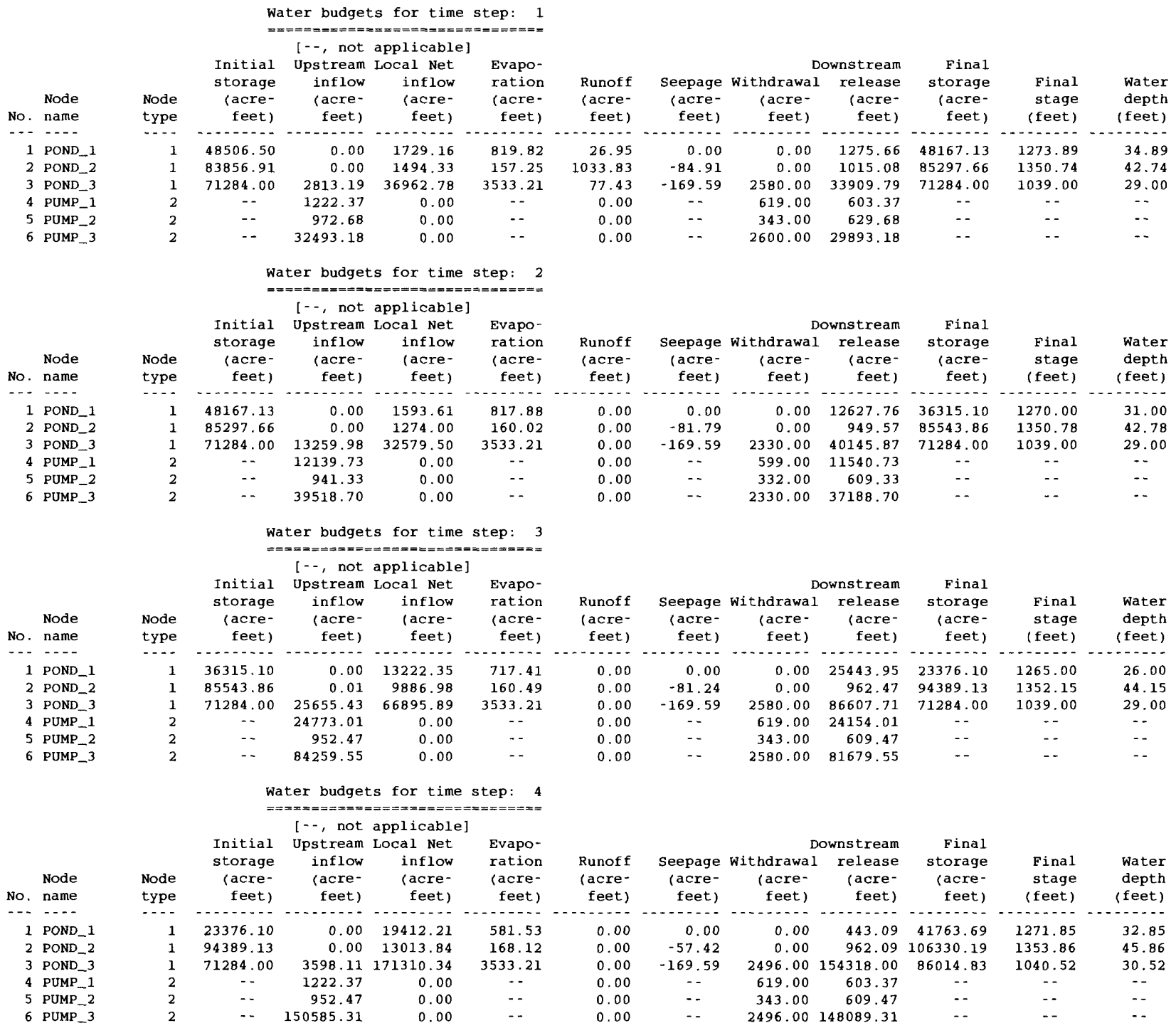




\begin{tabular}{|c|c|c|c|c|c|c|c|c|c|c|c|c|c|}
\hline \multirow[b]{2}{*}{ No. } & \multicolumn{6}{|c|}{ 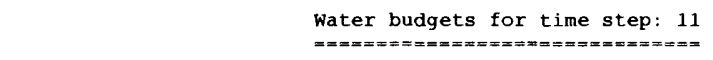 } & \multirow[b]{2}{*}{$\begin{array}{c}\text { Runoff } \\
\text { (acre- } \\
\text { feet) }\end{array}$} & \multirow[b]{2}{*}{$\begin{array}{r}\text { Seepage } \\
\text { (acre- } \\
\text { feet) }\end{array}$} & & & \multirow[b]{2}{*}{$\begin{array}{r}\text { Final } \\
\text { stage } \\
\text { (feet) }\end{array}$} & \multirow[b]{2}{*}{$\begin{array}{r}\text { water } \\
\text { depth } \\
\text { (feet) }\end{array}$} \\
\hline & $\begin{array}{l}\text { Node } \\
\text { name }\end{array}$ & $\begin{array}{l}\text { Node } \\
\text { type }\end{array}$ & $\begin{array}{r}\text { Initial } \\
\text { storage } \\
\text { (acre- } \\
\text { feet) }\end{array}$ & $\begin{array}{r}{[\cdots, \text { not }} \\
\text { Upstream } \\
\text { inflow } \\
\text { (acre- } \\
\text { feet) }\end{array}$ & $\begin{array}{c}\text { applicable] } \\
\text { Local Net } \\
\text { inflow } \\
\text { (acre- } \\
\text { feet) }\end{array}$ & $\begin{array}{l}\text { Evapo- } \\
\text { ration } \\
\text { (acre- } \\
\text { feet) }\end{array}$ & & & $\begin{array}{l}\text { Do } \\
\text { Withdrawa } 1 \\
\text { (acre- } \\
\text { feet) }\end{array}$ & $\begin{array}{r}\text { ownstream } \\
\text { release } \\
\text { (acre- } \\
\text { feet) }\end{array}$ & $\begin{array}{r}\text { Final } \\
\text { storage } \\
\text { (acre- } \\
\text { feet) }\end{array}$ & & \\
\hline- & $\cdots$ & $\cdots$ & (n) & - & 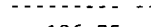 & 等 & & - & - & - & . & & \\
\hline 1 & POND_1 & 1 & 38055.91 & 0.00 & -126.75 & 737.82 & 0.00 & 0.00 & 0.00 & 1234.71 & 35956.62 & 1269.87 & 30.87 \\
\hline 2 & POND_2 & 1 & 76905.67 & -0.01 & 94.50 & 149.49 & 0.00 & -101.28 & 0.00 & 961.74 & 75990.21 & 1349.20 & 41.20 \\
\hline 3 & POND_3 & 1 & 71284.00 & 2874.25 & 66.27 & 3533.21 & 0.00 & -169.59 & 2496.00 & 3038.96 & 65325.95 & 1038.32 & 28.32 \\
\hline 4 & PUMP_1 & 2 & $\cdots$ & 1222.37 & 0.00 & - - & 0.00 & - - & 619.00 & 603.37 & - - & -- & -- \\
\hline 5 & PUMP_2 & 2 & $\cdots$ & 951.97 & 0.00 & -- & 0.00 & -- & 343.00 & 608.97 & -- & -- & -- \\
\hline 6 & PUMP_3 3 & 2 & $\cdots$ & 3099.37 & 0.00 & -- & 0.00 & - - & 2496.00 & 603.37 & - - & -- & -- \\
\hline & & & & $\begin{array}{c}\text { ter budget } \\
===x==x==0 \\
{[-, \text { not }}\end{array}$ & $\begin{array}{l}\text { ts for time } \\
\text { applicable] }\end{array}$ & step: 12 & & & & & & & \\
\hline No. & $\begin{array}{l}\text { Node } \\
\text { name }\end{array}$ & $\begin{array}{l}\text { Node } \\
\text { type }\end{array}$ & $\begin{array}{r}\text { Initial } \\
\text { storage } \\
\text { (acre- } \\
\text { feet) }\end{array}$ & $\begin{array}{l}\text { Upstream } \\
\text { inflow } \\
\text { (acre- } \\
\text { feet) }\end{array}$ & $\begin{array}{c}\text { Local Net } \\
\text { inflow } \\
\text { (acre- } \\
\text { feet) }\end{array}$ & $\begin{array}{l}\text { Evapo- } \\
\text { ration } \\
\text { (acre- } \\
\text { feet) }\end{array}$ & $\begin{array}{c}\text { Runoff } \\
\text { (acre- } \\
\text { feet) }\end{array}$ & $\begin{array}{r}\text { Seepage } \\
\text { (acre- } \\
\text { feet) }\end{array}$ & $\begin{array}{l}\text { Withdrawal } \\
\text { (acre- } \\
\text { feet) }\end{array}$ & $\begin{array}{r}\text { ownstream } \\
\text { release } \\
\text { (acre- } \\
\text { feet) }\end{array}$ & $\begin{array}{r}\text { Final } \\
\text { storage } \\
\text { (acre- } \\
\text { feet) }\end{array}$ & $\begin{array}{r}\text { Final } \\
\text { stage } \\
\text { (feet) }\end{array}$ & $\begin{array}{r}\text { Water } \\
\text { depth } \\
\text { (feet) }\end{array}$ \\
\hline$\cdots$ & $\cdots$ & $\cdots$ & - & - & 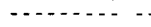 & - . . - & - & - & 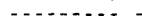 & 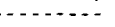 & 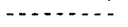 & - & . . . . . \\
\hline 1 & POND_1 & 1 & 35956.62 & 0.00 & 77.64 & 715.59 & 0.00 & 0.00 & 0.00 & 1213.86 & 34104.81 & 1269.21 & 30.21 \\
\hline 2 & POND_2 & 1 & 75990.21 & 0.00 & 314.43 & 149.03 & 0.00 & -103.64 & 0.00 & 950.63 & 75308.61 & 1349.09 & 41.09 \\
\hline 3 & POND_3 & 1 & 65325.95 & 2874.26 & 7617.22 & 3309.39 & 0.00 & -176.67 & 2580.00 & 3218.86 & 66885.85 & 1038.50 & 28.50 \\
\hline 4 & PUMP_1 & 2 & -- & 1202.37 & 0.00 & - - & 0.00 & $\cdots$ & 599.00 & 603.37 & -- & $\cdots$ & - \\
\hline 5 & PUMP_2 & 2 & - & 941.47 & 0.00 & -- & 0.00 & $\cdots$ & 332.00 & 609.47 & -- & -- & -- \\
\hline 6 & PUMP_3 & 2 & -- & 3183.37 & 0.00 & - - & 0.00 & $-\cdot$ & 2580.00 & 603.37 & - - & - - & $\cdots$ \\
\hline
\end{tabular}

\section{Output File for Canal Water Budgets (arbt.out)}

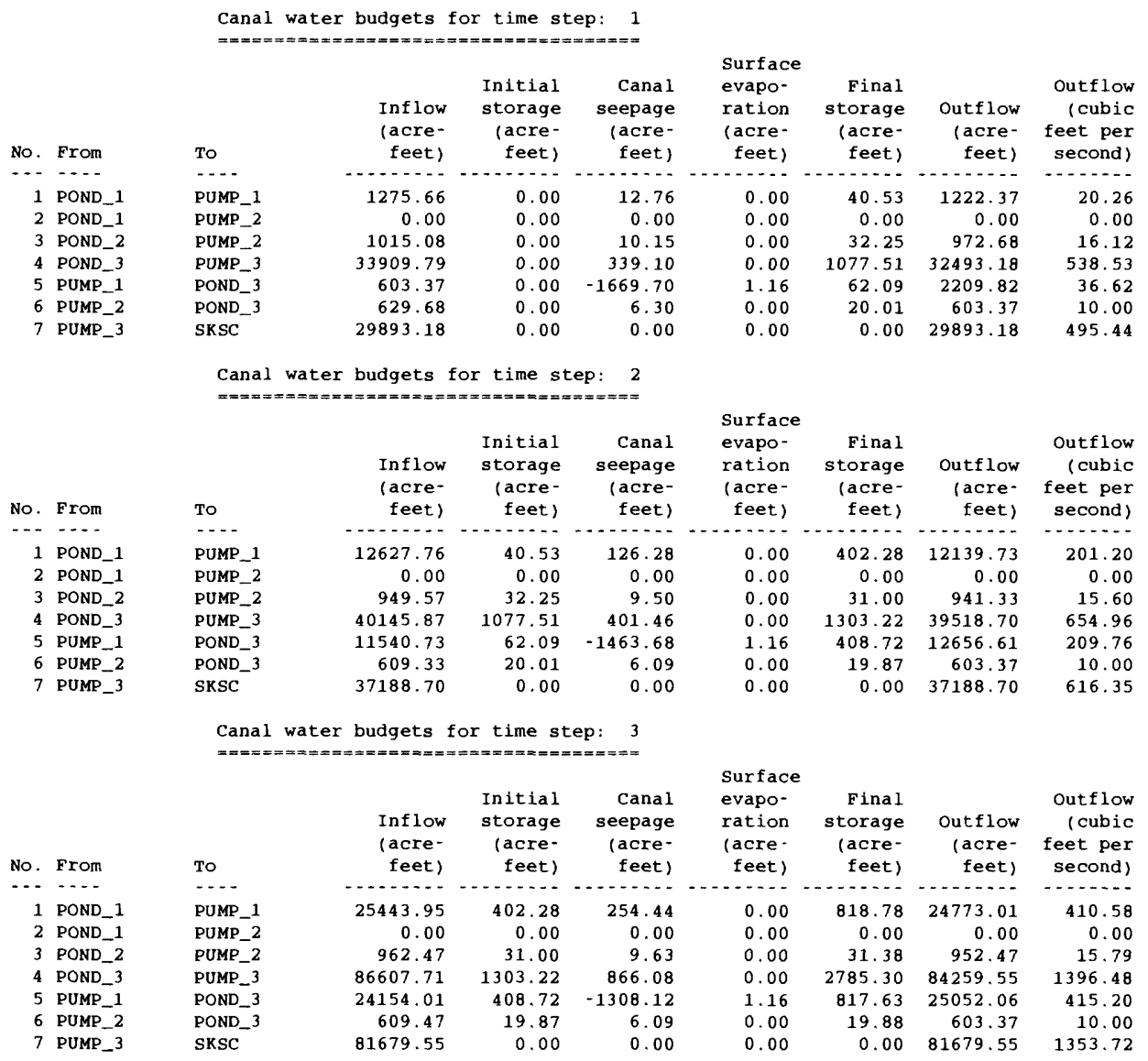




\begin{tabular}{rll} 
No & From & TO \\
\hdashline..-- &.-- \\
1 & POND_1 & PUMP_1 \\
2 & POND_1 & PUMP_2 \\
3 & POND_2 & PUMP_2 \\
4 & POND_3 & PUMP_3 \\
5 & PUMP_1 & POND_3 \\
6 & PUMP_2 & POND_3 \\
7 & PUMP_3 & SKSC
\end{tabular}

\begin{tabular}{|c|c|c|c|c|c|c|}
\hline $\begin{array}{c}\text { Inflow } \\
\text { (acre- } \\
\text { feet) }\end{array}$ & $\begin{array}{r}\text { Initial } \\
\text { storage } \\
\text { (acre- } \\
\text { feet) }\end{array}$ & $\begin{array}{r}\text { Canal } \\
\text { seepage } \\
\text { (acre- } \\
\text { feet) }\end{array}$ & $\begin{array}{l}\text { Surface } \\
\text { evapo- } \\
\text { ration } \\
\text { (acre- } \\
\text { feet) }\end{array}$ & $\begin{array}{r}\text { Final } \\
\text { storage } \\
\text { (acre- } \\
\text { feet) }\end{array}$ & $\begin{array}{l}\text { Outf low } \\
\text { (acre- } \\
\text { feet) }\end{array}$ & $\begin{array}{l}\text { Outflow } \\
\text { (cubic } \\
\text { feet per } \\
\text { second) }\end{array}$ \\
\hline$\ldots$ & - - - - - & $-\cdots$ & $\ldots$ & $\ldots$ & $\ldots . .$. & $\ldots$ \\
\hline 443.09 & 818.78 & 4.43 & 0.00 & 35.06 & 1222.37 & 20.26 \\
\hline 0.00 & 0.00 & 0.00 & 0.00 & 0.00 & 0.00 & 0.00 \\
\hline 962.09 & 31.38 & 9.62 & 0.00 & 31.37 & 952.47 & 15.79 \\
\hline 54318.00 & 2785.30 & 1543.18 & 0.00 & 4974.80 & 150585.31 & 2495.73 \\
\hline 603.37 & 817.63 & -1657.57 & 1.16 & 82.67 & 2994.74 & 49.63 \\
\hline 609.47 & 19.88 & 6.09 & 0.00 & 19.88 & 603.37 & 10.00 \\
\hline 148089.31 & 0.00 & 0.00 & 0.00 & 0.00 & 148089.31 & 2454.36 \\
\hline
\end{tabular}

No. From

1 POND 1

2 POND_1

3 POND_2

4 POND_3

5 PUMP_1

6 PUMP_2

7 PUMP_3

Canal water budgets for time step: 5

\begin{tabular}{|c|c|c|c|c|c|c|c|}
\hline & $\begin{array}{l}\text { Inflow } \\
\text { (acre- } \\
\text { feet) }\end{array}$ & $\begin{array}{r}\text { Initial } \\
\text { storage } \\
\text { (acre- } \\
\text { feet) }\end{array}$ & $\begin{array}{r}\text { Canal } \\
\text { seepage } \\
\text { (acre- } \\
\text { feet) }\end{array}$ & $\begin{array}{l}\text { Surface } \\
\text { evapo- } \\
\text { ration } \\
\text { (acre- } \\
\text { feet) }\end{array}$ & $\begin{array}{r}\text { Final } \\
\text { storage } \\
\text { (acre- } \\
\text { feet) }\end{array}$ & $\begin{array}{r}\text { Outf low } \\
\text { (acre- } \\
\text { feet) }\end{array}$ & $\begin{array}{l}\text { Outflow } \\
\text { (cubic } \\
\text { feet per } \\
\text { second) }\end{array}$ \\
\hline$M$ & 1219.14 & 35.06 & 12.19 & 0.00 & 39.64 & 1202.37 & 19.93 \\
\hline MP_2 & 0.00 & 0.00 & 0.00 & 0.00 & 0.00 & 0.00 & 0.00 \\
\hline MP_2 & 927.65 & 31.37 & 9.28 & 0.00 & 30.28 & 919.47 & 15.24 \\
\hline P_3 & 173304.08 & 4974.80 & 1733.04 & 0.00 & 5634.14 & 170911.70 & 2832.61 \\
\hline D_3 & 603.37 & 82.67 & -1668.38 & 1.16 & 64.17 & 2289.09 & 37.94 \\
\hline D_3 & 609.47 & 19.88 & 6.09 & 0.00 & 19.88 & 603.37 & 10.00 \\
\hline & 168331.70 & 0.00 & 0.00 & 0.00 & 0.00 & 168331.70 & 2789.85 \\
\hline
\end{tabular}

\begin{tabular}{rll} 
No. & From & TO \\
\hline 1 & POND_1 & PUMP_1 \\
2 & POND_1 & PUMP_2 \\
3 & POND_2 & PUMP_2 \\
4 & POND_3 & PUMP_3 \\
5 & PUMP_1 & POND_3 \\
6 & PUMP_2 & POND_3
\end{tabular}

7 POND_

Canal water budgets for time step: 6

\begin{tabular}{|c|c|c|c|c|c|c|c|}
\hline & $\begin{array}{r}\text { Inflow } \\
\text { (acre- } \\
\text { feet) }\end{array}$ & $\begin{array}{r}\text { Initial } \\
\text { storage } \\
\text { (acre- } \\
\text { feet) }\end{array}$ & $\begin{array}{r}\text { Cana1 } \\
\text { seepage } \\
\text { (acre- } \\
\text { feet) }\end{array}$ & $\begin{array}{l}\text { Surface } \\
\text { evapo- } \\
\text { ration } \\
\text { (acre- } \\
\text { feet) }\end{array}$ & $\begin{array}{r}\text { Final } \\
\text { storage } \\
\text { (acre- } \\
\text { feet) }\end{array}$ & $\begin{array}{c}\text { Outflow } \\
\text { (acre- } \\
\text { feet) }\end{array}$ & $\begin{array}{r}\text { Outflow } \\
\text { (cubic } \\
\text { feet per } \\
\text { second) }\end{array}$ \\
\hline & a & ...... & ar & 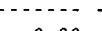 & ....... & - - - - & 2026 \\
\hline MP_1 & 1235.36 & 39.64 & 12.35 & 0.00 & 40.27 & 1222.37 & 20.26 \\
\hline AP_2 & 0.00 & 0.00 & 0.00 & 0.00 & 0.00 & 0.00 & 0.00 \\
\hline PUMP_2 & 963.20 & 30.28 & 9.63 & 0.00 & 31.38 & 952.47 & 15.79 \\
\hline UMP_3 3 & 155599.08 & 5634.14 & 1555.99 & 0.00 & 5088.44 & 154588.78 & 2562.08 \\
\hline OND_3 & 603.37 & 64.17 & -1668.68 & 1.16 & 63.70 & 2271.35 & 37.64 \\
\hline D_3 & 609.47 & 19.88 & 6.09 & 0.00 & 19.88 & 603.37 & 10.00 \\
\hline
\end{tabular}

Canal water budgets for time step: 7

\begin{tabular}{rll} 
No. & From & TO \\
\hdashline-1 & POND_1 & PUMP_1 \\
2 & POND_1 & PUMP_2 \\
3 & POND_2 & PUMP_2 \\
4 & POND_3 & PUMP_3 \\
5 & PUMP_1 & POND_3 \\
6 & PUMP_2 & POND_3 \\
7 & PUMP_3 & SKSC
\end{tabular}

\begin{tabular}{rrr} 
Inflow & $\begin{array}{r}\text { Initial } \\
\text { storage } \\
\text { (acre- } \\
\text { feet) }\end{array}$ & $\begin{array}{r}\text { Canal } \\
\text { seepage } \\
\text { (acre- } \\
\text { feet) }\end{array}$ \\
\hline 1213.84 & 40.27 & 12.14 \\
0.00 & 0.00 & 0.00 \\
950.60 & 31.38 & 9.51 \\
63981.50 & 5088.44 & 639.82 \\
603.37 & 63.70 & -1668.68 \\
609.47 & 19.88 & 6.09 \\
63686.83 & 0.00 & 0.00
\end{tabular}

\begin{tabular}{rrrr}
$\begin{array}{r}\text { Surface } \\
\text { evapo- } \\
\text { ration } \\
\text { (acre- } \\
\text { feet) }\end{array}$ & $\begin{array}{r}\text { Final } \\
\text { storage } \\
\text { (acre- } \\
\text { feet) }\end{array}$ & $\begin{array}{r}\text { Outflow } \\
\text { (acre- } \\
\text { feet) }\end{array}$ & $\begin{array}{r}\text { Outflow } \\
\text { (cubic } \\
\text { feet per } \\
\text { second) }\end{array}$ \\
\hline 0.00 & 39.60 & 1202.37 & 19.93 \\
0.00 & 0.00 & 0.00 & 0.00 \\
0.00 & 31.01 & 941.47 & 15.60 \\
0.00 & 2163.30 & 66266.83 & 1098.28 \\
1.16 & 63.69 & 2270.90 & 37.64 \\
0.00 & 19.88 & 603.37 & 10.00 \\
0.00 & 0.00 & 63686.83 & 1055.52
\end{tabular}

Canal water budgets for time step: 8

\begin{tabular}{rll} 
No. & From & TO \\
\hdashline..- &..- \\
1 & POND_1 & PUMP_1 \\
2 & POND_1 & PUMP_2 \\
3 & POND_2 & PUMP_2 \\
4 & POND_3 & PUMP_3 \\
5 & PUMP_1 & POND_3 \\
6 & PUMP_2 & POND_3 \\
7 & PUMP_3 & SKSC
\end{tabular}

\begin{tabular}{|c|c|c|}
\hline $\begin{array}{l}\text { Inflow } \\
\text { (acre- } \\
\text { feet) }\end{array}$ & $\begin{array}{r}\text { Initial } \\
\text { storage } \\
\text { (acre- } \\
\text { feet) }\end{array}$ & $\begin{array}{r}\text { Canal } \\
\text { seepage } \\
\text { (acre- } \\
\text { feet) }\end{array}$ \\
\hline 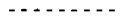 & & \\
\hline 235.39 & 39.60 & \\
\hline 0.00 & 0.00 & \\
\hline 32402.33 & 31.01 & 324 \\
\hline 57100.34 & 163.30 & 571. \\
\hline 603.37 & 63.69 & 1668. \\
\hline 30735.96 & 19.88 & 307 \\
\hline 54242.88 & 0.00 & \\
\hline
\end{tabular}

\begin{tabular}{rrrr}
$\begin{array}{r}\text { Surface } \\
\text { evapo- } \\
\text { ration } \\
\text { (acre- } \\
\text { feet) }\end{array}$ & $\begin{array}{r}\text { Final } \\
\text { storage } \\
\text { (acre- } \\
\text { feet) }\end{array}$ & $\begin{array}{r}\text { Outflow } \\
\text { (acre- } \\
\text { feet) }\end{array}$ & $\begin{array}{r}\text { Outflow } \\
\text { (cubic } \\
\text { feet per } \\
\text { second) }\end{array}$ \\
\hline 0.00 & 40.27 & 1222.37 & 20.26 \\
0.00 & 0.00 & 0.00 & 0.00 \\
0.00 & 1030.36 & 31078.96 & 515.09 \\
0.00 & 1869.75 & 56822.88 & 941.76 \\
1.16 & 63.69 & 2270.88 & 37.64 \\
0.00 & 977.13 & 29471.35 & $\mathbf{4 8 8 . 4 4}$ \\
0.00 & 0.00 & 54242.88 & 899.00
\end{tabular}

Outflow eet per second) 20.26 515.09 37.64 899.00 


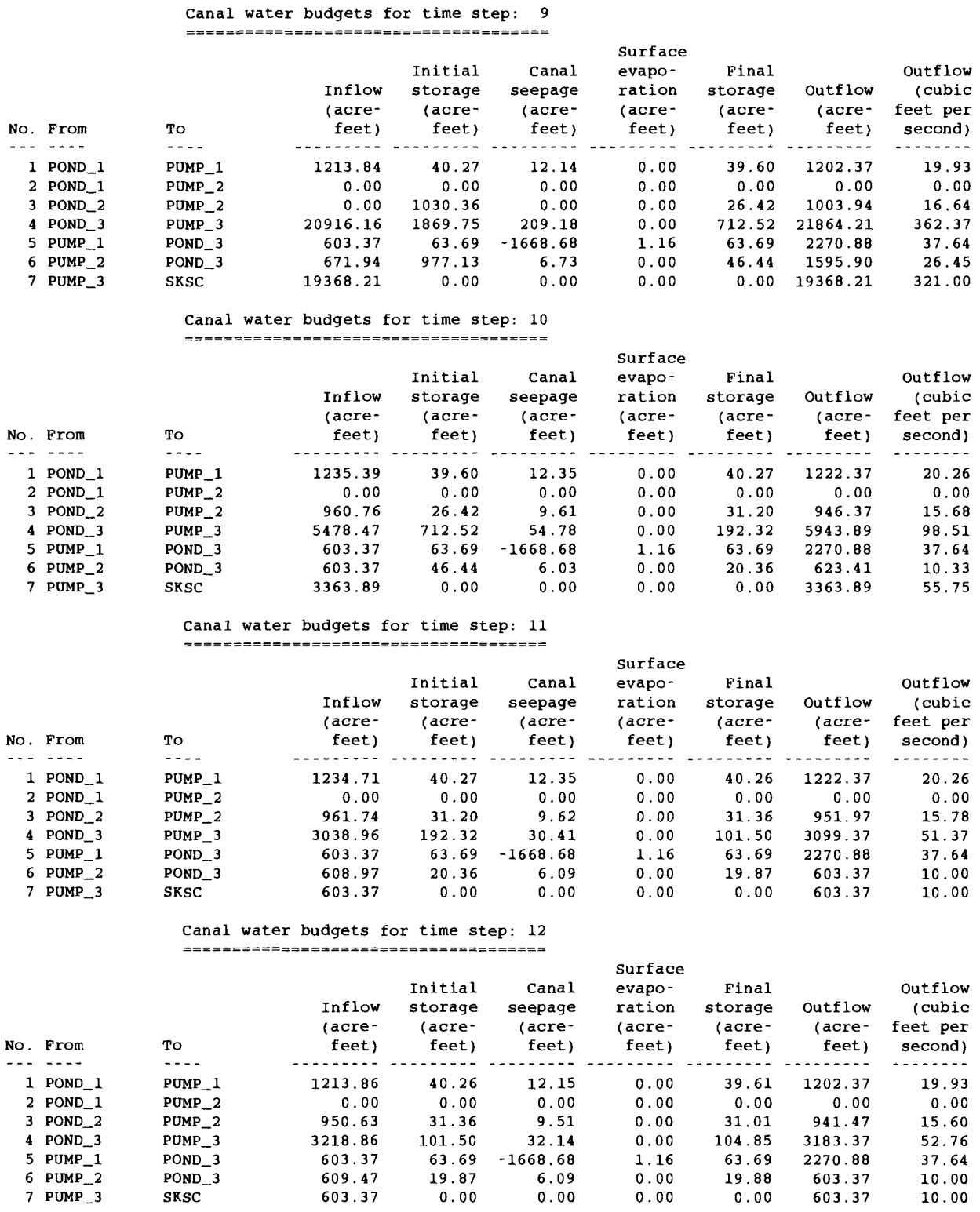

\section{Output File for Operation of Hydraulic Structures (hydr.out)}

\begin{tabular}{|c|c|c|c|c|c|c|c|c|}
\hline \multirow[b]{2}{*}{$\begin{array}{l}\text { Structure } \\
\text { name }\end{array}$} & \multicolumn{5}{|c|}{$\begin{array}{l}\text { Parameters for hydraulic structures: } 1 \\
====================================== \\
{[-999.99, \text { not flow under gate }]}\end{array}$} & \multirow[b]{2}{*}{$\begin{array}{l}\text { Discharge } \\
\text { (cubic } \\
\text { feet per } \\
\text { second) }\end{array}$} & \multirow[b]{2}{*}{$\begin{array}{l}\text { Upstream } \\
\text { Water } \\
\text { elevation } \\
\text { (feet) }\end{array}$} & \multirow[b]{2}{*}{$\begin{array}{l}\text { Gate-opening } \\
\text { or weir } \\
\text { height } \\
\quad \text { (feet) }\end{array}$} \\
\hline & $\begin{array}{l}\text { Upstream } \\
\text { node } \\
\text { name }\end{array}$ & $\begin{array}{l}\text { Downstream } \\
\text { node } \\
\text { name }\end{array}$ & $\begin{array}{l}\text { Structure } \\
\text { type }\end{array}$ & $\begin{array}{l}\text { Base } \\
\text { elevation } \\
\quad(\text { feet })\end{array}$ & $\begin{array}{l}\text { Weir } \\
\text { length } \\
\text { (feet) }\end{array}$ & & & \\
\hline$---\cdot$ & $-\cdots--$ & $-\cdots--$ & $-\cdots$ & $\ldots \ldots$ & 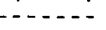 & $-\cdots--\cdots$ & $----\ldots$ & $-\ldots-\ldots$ \\
\hline Gate-1 & Pond_1 & Pump_1 & Gate spillway & 1240.00 & 2.00 & 21.14 & 1274.00 & 0.35 \\
\hline Weir-2 & Pond_2 & Pump_2 & Sharp-crested weir & 1340.00 & 2.00 & 16.82 & 1350.50 & 8.65 \\
\hline Gate-3 & Pond_3 & Pump_3 & sluice gate & 1020.00 & 10.00 & 562.00 & 1039.00 & 2.90 \\
\hline
\end{tabular}


Parameters for hydraulic structures: 2

[ -999.99 , not flow under gate]

\begin{tabular}{|c|c|c|c|c|c|c|c|c|}
\hline $\begin{array}{l}\text { structure } \\
\text { name }\end{array}$ & $\begin{array}{l}\text { Upstream } \\
\text { node } \\
\text { name }\end{array}$ & $\begin{array}{l}\text { Downstream } \\
\text { node } \\
\text { name }\end{array}$ & $\begin{array}{l}\text { structure } \\
\text { type }\end{array}$ & $\begin{array}{l}\text { Base } \\
\text { elevation } \\
\quad \text { (feet) }\end{array}$ & $\begin{array}{l}\text { Weir } \\
\text { length } \\
\text { (feet) }\end{array}$ & $\begin{array}{l}\text { Discharge } \\
\text { (cubic } \\
\text { feet per } \\
\text { second) }\end{array}$ & $\begin{array}{l}\text { Upstream } \\
\text { Water } \\
\text { elevation } \\
\text { (feet) }\end{array}$ & $\begin{array}{l}\text { Gate-opening } \\
\text { or weir } \\
\text { height } \\
\text { (feet) }\end{array}$ \\
\hline-- & ---- & $\cdots$ & $-\cdots$ & $\cdots----$ & ---- &.-----1 & 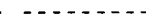 & $-\cdots---$ \\
\hline ate-1 & Pond_1 & Pump_1 & Gate spillway & 1240.00 & 2.00 & 209.29 & 1273.89 & 3.55 \\
\hline eir-2 & Pond_2 & Pump_2 & Sharp-crested weir & 1340.00 & 2.00 & 15.74 & 1350.74 & 8.97 \\
\hline Gate-3 & Pond_3 & Pump_3 & sluice gate & 1020.00 & 10.00 & 665.36 & 1039.00 & 3.48 \\
\hline
\end{tabular}

Parameters for hydraulic structures: 3

[ -999.99 , not flow under gate]

name

Gate-1

Weir-2

Gate-3

$\begin{array}{ll}\begin{array}{l}\text { Downstream } \\ \text { node } \\ \text { name }\end{array} & \text { Structure } \\ \text { type } \\ \text { Pump_1 } & --- \\ \text { Pump_2 } & \text { Gate spillway } \\ \text { Pump_3 } & \text { Sharp-crested weir }\end{array}$

\begin{tabular}{|c|c|c|c|c|}
\hline & & Disch & $\mathrm{am}$ & 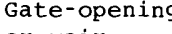 \\
\hline Bas & Weir & LC & ter & or weir \\
\hline $\begin{array}{r}\text { elevation } \\
\text { (feet) }\end{array}$ & $\begin{array}{l}\text { length } \\
\text { (feet) }\end{array}$ & $\begin{array}{r}\text { feet per } \\
\text { second) }\end{array}$ & $\begin{array}{r}\text { elevation } \\
\text { (feet) }\end{array}$ & $\begin{array}{l}\text { height } \\
\text { (feet) }\end{array}$ \\
\hline------ & --- & $----\cdots--$ & $---\cdot-\cdot-$ & -- \\
\hline 1240.00 & 2.00 & 421.70 & 1270.00 & 7.99 \\
\hline 1340.00 & 2.00 & 15.95 & 1350.78 & 9.00 \\
\hline 1020.00 & 10.00 & 1435.40 & 1039.00 & 8.07 \\
\hline
\end{tabular}

Parameters for hydraulic structures: 4

[-999.99, not flow under gate]

Upstream

Downstream

node node

name name

Pond_1 Pump_1

Pump_1

Pump 3

Structure
type
Gate spillway
Sharp-crested weir
Sluice gate

\begin{tabular}{rrrrr}
$\begin{array}{r}\text { Base } \\
\text { elevation } \\
\text { (feet) }\end{array}$ & $\begin{array}{r}\text { Weir } \begin{array}{r}\text { (cubic } \\
\text { (feet) }\end{array} \\
\text { (feet per } \\
\text { second) }\end{array}$ & $\begin{array}{r}\text { water } \\
\text { elevation } \\
\text { (feet) }\end{array}$ & $\begin{array}{r}\text { or weir } \\
\text { height } \\
\text { (feet) }\end{array}$ \\
\hline 1240.00 & 2.00 & 7.34 & 1265.00 & 0.14 \\
1340.00 & 2.00 & 15.95 & 1352.15 & 10.37 \\
1020.00 & 10.00 & 2557.59 & 1039.00 & -999.99
\end{tabular}

Parameters for hydraulic structures: 5

[-999.99, not flow under gate]

structure

name

$---$

Gate-1

Weir-2

Gate-3

Downstream

node

structure

name

type

name

$----$

Pond 1 Pump 1

Pond_2

Pump_2

Gate spillway

Pond_3

Pump_3

Sharp-crested weir

sluice gate

\begin{tabular}{rrrrr}
$\begin{array}{l}\text { Base } \\
\text { elevation } \\
\text { (feet) }\end{array}$ & $\begin{array}{l}\text { Weir } \\
\text { length } \\
\text { (feet) }\end{array}$ & $\begin{array}{r}\text { Discharge } \\
\text { (cubic per } \\
\text { second) }\end{array}$ & $\begin{array}{l}\text { Upstream Gate-opening } \\
\text { Water } \\
\text { elevation } \\
\text { (feet) }\end{array}$ & $\begin{array}{l}\text { or weight } \\
\text { (feet) }\end{array}$ \\
\hline 1240.00 & 2.00 & 20.21 & 1271.85 & 0.34 \\
1340.00 & 2.00 & 15.37 & 1353.87 & 12.12 \\
1020.00 & 10.00 & 2872.26 & 1040.53 & -999.99
\end{tabular}

parameters for hydraulic structures: 6

[ -999.99 , not flow under gate]

structure

name

-..-

Gate-1

Weir-2

Gate- 3

Upstream
node
name
Pond_1
Pond_2
Pond_3

Downstream
node
name
Pump_1
Pump_2
Pump_3

Structure
type
Gate spillway
Sharp-crested weir
Sluice gate

Bas

\begin{tabular}{|c|c|c|c|c|}
\hline $\begin{array}{l}\text { Base } \\
\text { elevation } \\
\text { (feet) }\end{array}$ & $\begin{array}{l}\text { Weir } \\
\text { length } \\
\text { (feet) }\end{array}$ & $\begin{array}{l}\text { Discharge } \\
\text { (cubic } \\
\text { feet per } \\
\text { second) }\end{array}$ & $\begin{array}{l}\text { Upstream } \\
\text { Water } \\
\text { elevation } \\
\text { (feet) }\end{array}$ & $\begin{array}{l}\text { Gate-opening } \\
\text { or weir } \\
\text { height } \\
\text { (feet) }\end{array}$ \\
\hline.----- &.---- &.----- & $-\ldots----0$ & $-.-1--$ \\
\hline 1240.00 & 2.00 & 20.47 & 1273.26 & 0.34 \\
\hline 1340.00 & 2.00 & 15.96 & 1354.79 & 13.00 \\
\hline 1020.00 & 10.00 & 2578.83 & 1042.99 & 13.84 \\
\hline
\end{tabular}

Parameters for hydraulic structures: 7

[ -999.99 , not flow under gate]

Structure

name

-....

Gate-1

Weir-2

Gate-3

Downstream

Upstream

node

name

Pond_1

Pond_2

Pond_3

Downstream
node
name
-
Pump_1
Pump_2
Pump_3

Structure
type
Gate spillway
Sharp-crested weir
sluice gate

\begin{tabular}{rrrrr}
$\begin{array}{r}\text { Base } \\
\text { elevation } \\
\text { (feet) }\end{array}$ & $\begin{array}{r}\text { Weir } \begin{array}{c}\text { Discharge } \\
\text { length } \\
\text { (feet) }\end{array} \\
\text { feet per } \\
\text { second) }\end{array}$ & $\begin{array}{r}\text { Upstream Gate-opening } \\
\text { Water } \\
\text { elevation } \\
\text { (feet) }\end{array}$ & $\begin{array}{r}\text { or weir } \\
\text { (feet) }\end{array}$ \\
\hline 1240.00 & 2.00 & 20.12 & 1272.84 & 0.34 \\
1340.00 & 2.00 & 15.75 & 1354.96 & 13.18 \\
1020.00 & 10.00 & 1060.40 & 1039.00 & 5.76
\end{tabular}




\begin{tabular}{|c|c|c|c|c|c|c|c|c|}
\hline \multirow[b]{2}{*}{$\begin{array}{l}\text { Structure } \\
\text { name }\end{array}$} & \multicolumn{5}{|c|}{$\begin{array}{l}\text { Parameters for hydraulic structures: } 8 \\
================================== \pm===== \\
{[-999.99, \text { not flow under gate }]}\end{array}$} & \multirow[b]{2}{*}{$\begin{array}{l}\text { Discharge } \\
\text { (cubic } \\
\text { feet per } \\
\text { second) }\end{array}$} & \multirow[b]{2}{*}{$\begin{array}{l}\text { Upstream } \\
\text { Water } \\
\text { elevation } \\
\text { (feet) }\end{array}$} & \multirow[b]{2}{*}{$\begin{array}{l}\text { Gate-opening } \\
\text { or weir } \\
\text { height } \\
\quad \text { (feet) }\end{array}$} \\
\hline & $\begin{array}{l}\text { Upstream } \\
\text { node } \\
\text { name }\end{array}$ & $\begin{array}{l}\text { Downstream } \\
\text { node } \\
\text { name }\end{array}$ & $\begin{array}{l}\text { Structure } \\
\text { type }\end{array}$ & $\begin{array}{l}\text { Base } \\
\text { elevation } \\
\text { (feet) }\end{array}$ & $\begin{array}{l}\text { Weir } \\
\text { length } \\
\text { (feet) }\end{array}$ & & & \\
\hline----- & ----- & $-\ldots$ & $\ldots-$ & $\ldots \ldots$ & $\ldots \ldots$ & $\ldots \ldots \ldots$ & 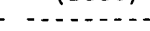 & $-\ldots . . .-1$ \\
\hline Gate-1 & Pond_1 & Pump_1 & Gate spillway & 1240.00 & 2.00 & 20.47 & 1272.06 & 0.35 \\
\hline Weir-2 & Pond_2 & Pump_2 & Sharp-crested weir & 1340.00 & 2.00 & 537.02 & 1354.82 & 1.95 \\
\hline Gate-3 & Pond_3 & Pump_3 & sluice gate & 1020.00 & 10.00 & 946.35 & 1039.00 & 5.09 \\
\hline
\end{tabular}

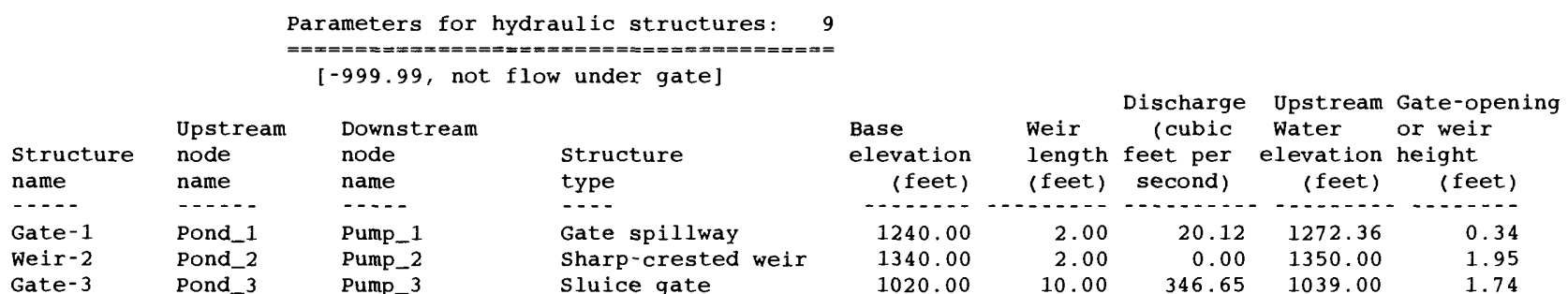

Parameters for hydraulic structures: 10

$[-999.99$, not flow under gate]

\begin{tabular}{|c|c|c|c|c|c|c|c|c|}
\hline $\begin{array}{l}\text { Structure } \\
\text { name }\end{array}$ & $\begin{array}{l}\text { Upstream } \\
\text { node } \\
\text { name }\end{array}$ & $\begin{array}{l}\text { Downstream } \\
\text { node } \\
\text { name }\end{array}$ & $\begin{array}{l}\text { structure } \\
\text { type }\end{array}$ & $\begin{array}{l}\text { Base } \\
\text { elevation } \\
\quad(\text { feet) }\end{array}$ & $\begin{array}{l}\text { Weir } \\
\text { length } \\
\text { (feet) }\end{array}$ & $\begin{array}{r}\text { (cubic } \\
\text { feet per } \\
\text { second) }\end{array}$ & $\begin{array}{l}\text { Wpstream } \\
\text { water } \\
\text { elevation } \\
\text { (feet) }\end{array}$ & $\begin{array}{l}\text { or weir } \\
\text { height } \\
\text { (feet) }\end{array}$ \\
\hline$-\ldots-$ & $\ldots \ldots$ & $-\ldots$ & $-\ldots$ & $\ldots-\ldots$ & $-\ldots-\ldots$ & $\ldots \ldots \ldots$ & $-\ldots . . .$. & $\ldots \ldots$ \\
\hline Gate-1 & Pond__1 & Pump_1 & Gate spillway & 1240.00 & 2.00 & 20.47 & 1271.42 & 0.35 \\
\hline Weir-2 & Pond_2 & Pump_2 & Sharp-crested weir & 1340.00 & 2.00 & 15.92 & 1349.74 & 7.96 \\
\hline Gate-3 & Pond_3 & Pump_3 & sluice gate & 1020.00 & 10.00 & 90.80 & 1039.00 & 0.43 \\
\hline
\end{tabular}

Parameters for hydraulic structures: 11

[-999.99, not flow under gate]

\begin{tabular}{llll} 
Structure & $\begin{array}{l}\text { Upstream } \\
\text { node }\end{array}$ & $\begin{array}{l}\text { Downstream } \\
\text { node }\end{array}$ & $\begin{array}{l}\text { Structure } \\
\text { nype }\end{array}$ \\
name & name & - & -- \\
\hline Gate-1 & Pond_1 & Pump_1 & Gate spillway \\
Weir-2 & Pond_2 & Pump_2 & Sharp-crested weir \\
Gate-3 & Pond_3 & Pump_3 & Sluice gate
\end{tabular}

\begin{tabular}{|c|c|c|c|c|}
\hline ase & Weir & $\begin{array}{c}\text { Discharge } \\
\text { (cubic }\end{array}$ & $\begin{array}{l}\text { Upstream } \\
\text { Water }\end{array}$ & $\begin{array}{l}\text { Gate-opening } \\
\text { or weir }\end{array}$ \\
\hline $\begin{array}{r}\text { elevation } \\
\text { (feet) }\end{array}$ & $\begin{array}{l}\text { length } \\
\text { (feet) }\end{array}$ & $\begin{array}{l}\text { feet per } \\
\text { second) }\end{array}$ & $\begin{array}{r}\text { elevation } \\
\text { (feet) }\end{array}$ & $\begin{array}{l}\text { height } \\
\text { (feet) }\end{array}$ \\
\hline 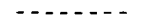 & $\cdots$ & 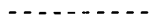 & 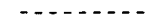 & --- \\
\hline 1240.00 & 2.00 & 20.46 & 1270.60 & 0.36 \\
\hline 1340.00 & 2.00 & 15.94 & 1349.35 & 7.58 \\
\hline 1020.00 & 10.00 & 50.37 & 1039.00 & 0.24 \\
\hline
\end{tabular}

Parameters for hydraulic structures: 12

[ -999.99 , not flow under gate]

\begin{tabular}{|c|c|c|c|}
\hline $\begin{array}{l}\text { Structure } \\
\text { name }\end{array}$ & $\begin{array}{l}\text { Upstream } \\
\text { node } \\
\text { name }\end{array}$ & $\begin{array}{l}\text { Downstream } \\
\text { node } \\
\text { name }\end{array}$ & $\begin{array}{l}\text { structure } \\
\text { type }\end{array}$ \\
\hline---- & $-\cdots$ &.--- & $-1-$ \\
\hline Gate-1 & Pond_1 & Pump_1 & Gate spillway \\
\hline Weir-2 & Pond_2 & Pump_2 & Sharp-crested weir \\
\hline Gate-3 & Pond 3 & Pump_3 & sluice gate \\
\hline
\end{tabular}

\begin{tabular}{|c|c|c|c|c|}
\hline $\begin{array}{l}\text { Base } \\
\text { elevation } \\
\text { (feet) }\end{array}$ & $\begin{array}{l}\text { Weir } \\
\text { length } \\
\text { (feet) }\end{array}$ & $\begin{array}{l}\text { Discharge } \\
\text { (cubic } \\
\text { feet per } \\
\text { second) }\end{array}$ & $\begin{array}{c}\text { Upstream } \\
\text { Water } \\
\text { elevation } \\
\text { (feet) }\end{array}$ & $\begin{array}{l}\text { Gate-opening } \\
\text { or weir } \\
\text { height } \\
\text { (feet) }\end{array}$ \\
\hline$-\cdots$ & $-\cdots$ & - & $-\cdots$ & $\ldots \ldots$ \\
\hline 1240.00 & 2.00 & 20.12 & 1269.87 & 0.35 \\
\hline 1340.00 & 2.00 & 15.76 & 1349.21 & 7.44 \\
\hline 1020.00 & 10.00 & 53.35 & 1038.33 & 0.26 \\
\hline
\end{tabular}

\section{Output File for Time-Series Output of Water Budget for Node Pond_1 (bpond_1.out)}

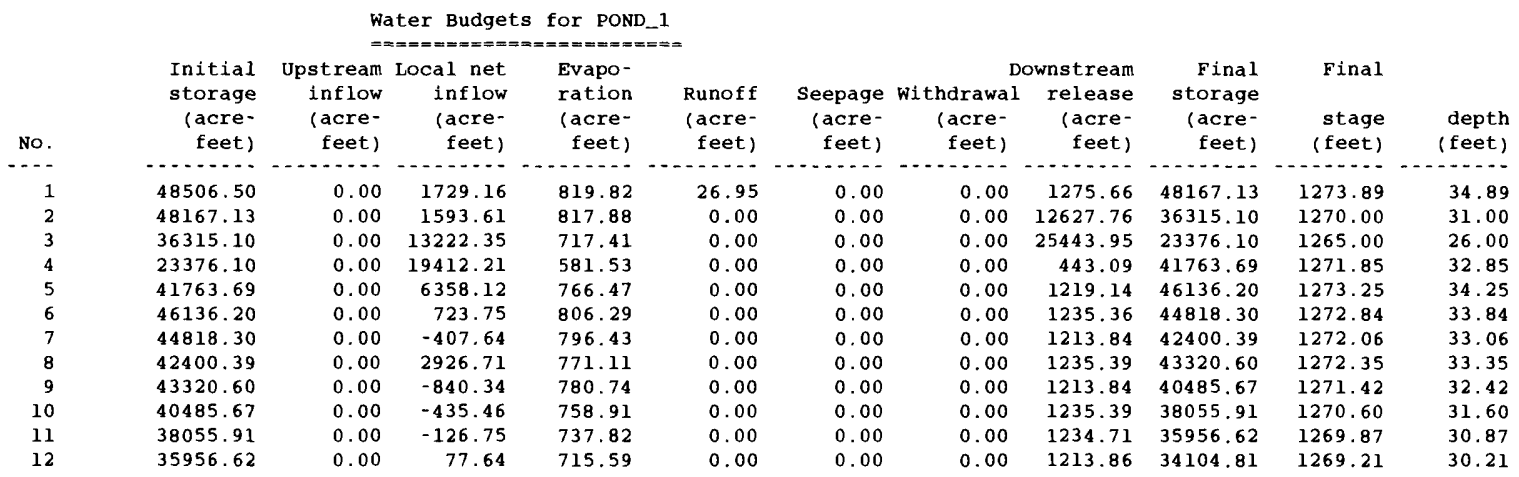




\section{Output File for Time-Series Output of Release from Node Pond_1 (rpond_1.dat)}

\begin{tabular}{|c|c|c|c|c|}
\hline & \multicolumn{2}{|c|}{ PUMP_1 } & \multicolumn{2}{|c|}{ PUMP_2 } \\
\hline & & (cubic & & (cubic \\
\hline D. & $\begin{array}{l}\text { (acre- } \\
\text { feet) }\end{array}$ & $\begin{array}{l}\text { feet per } \\
\text { second) }\end{array}$ & $\begin{array}{c}\text { (acre- } \\
\text { feet) }\end{array}$ & $\begin{array}{r}\text { feet per } \\
\text { second) }\end{array}$ \\
\hline 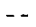 & $\ldots$ & $\cdots$ & $\ldots-$ & $\ldots$ \\
\hline 1 & 1275.66 & 21.14 & 0.00 & 0.00 \\
\hline 2 & 12627.76 & 209.29 & 0.00 & 0.00 \\
\hline 3 & 25443.95 & 421.70 & 0.00 & 0.00 \\
\hline 4 & 443.09 & 7.34 & 0.00 & 0.00 \\
\hline 5 & 1219.14 & 20.21 & 0.00 & 0.00 \\
\hline 6 & 1235.36 & 20.47 & 0.00 & 0.00 \\
\hline 7 & 1213.84 & 20.12 & 0.00 & 0.00 \\
\hline 8 & 1235.39 & 20.47 & 0.00 & 0.00 \\
\hline 9 & 1213.84 & 20.12 & 0.00 & 0.00 \\
\hline 0 & 1235.39 & 20.47 & 0.00 & 0.00 \\
\hline 1 & 1234.71 & 20.46 & 0.00 & 0.00 \\
\hline 2 & 1213.86 & 20.12 & 0.00 & 0.00 \\
\hline
\end{tabular}

\section{Output File for Time-Series Output of Arc Water Budget (arbud001.out)}

Canal water budgets from POND_l to PUMP_l

\begin{tabular}{|c|c|c|c|c|c|c|c|}
\hline No. & $\begin{array}{l}\text { Inflow } \\
\text { (acre- } \\
\text { feet) }\end{array}$ & $\begin{array}{c}\text { Initial } \\
\text { storage } \\
\text { (acre- } \\
\text { feet) }\end{array}$ & $\begin{array}{r}\text { Canal } \\
\text { seepage } \\
\text { (acre- } \\
\text { feet) }\end{array}$ & $\begin{array}{c}\text { Water- } \\
\text { surface } \\
\text { evapo- } \\
\text { ration } \\
\text { (acre- } \\
\text { feet) }\end{array}$ & $\begin{array}{r}\text { Final } \\
\text { storage } \\
\text { (acre- } \\
\text { feet) }\end{array}$ & $\begin{array}{l}\text { Outflow } \\
\text { (acre- } \\
\text { feet) }\end{array}$ & $\begin{array}{l}\text { Outflow } \\
\text { (cubic } \\
\text { feet per } \\
\text { second) }\end{array}$ \\
\hline & $\cdots$ & & $\cdots \cdots$ & $\cdots$ & & & $\cdots$ \\
\hline 1 & 1275.66 & 0.00 & 12.76 & 0.00 & 40.53 & 1222.37 & 20.26 \\
\hline 2 & 12627.76 & 40.53 & 126.28 & 0.00 & 402.28 & 12139.73 & 201.20 \\
\hline 3 & 25443.95 & 402.28 & 254.44 & 0.00 & 818.78 & 24773.01 & 410.58 \\
\hline 4 & 443.09 & 818.78 & 4.43 & 0.00 & 35.06 & 1222.37 & 20.26 \\
\hline 5 & 1219.14 & 35.06 & 12.19 & 0.00 & 39.64 & 1202.37 & 19.93 \\
\hline 6 & 1235.36 & 39.64 & 12.35 & 0.00 & 40.27 & 1222.37 & 20.26 \\
\hline 7 & 1213.84 & 40.27 & 12.14 & 0.00 & 39.60 & 1202.37 & 19.93 \\
\hline 8 & 1235.39 & 39.60 & 12.35 & 0.00 & 40.27 & 1222.37 & 20.26 \\
\hline 9 & 1213.84 & 40.27 & 12.14 & 0.00 & 39.60 & 1202.37 & 19.93 \\
\hline 10 & 1235.39 & 39.60 & 12.35 & 0.00 & 40.27 & 1222.37 & 20.26 \\
\hline 11 & 1234.71 & 40.27 & 12.35 & 0.00 & 40.26 & 1222.37 & 20.26 \\
\hline 12 & 1213.86 & 40.26 & 12.15 & 0.00 & 39.61 & 1202.37 & 19.93 \\
\hline
\end{tabular}




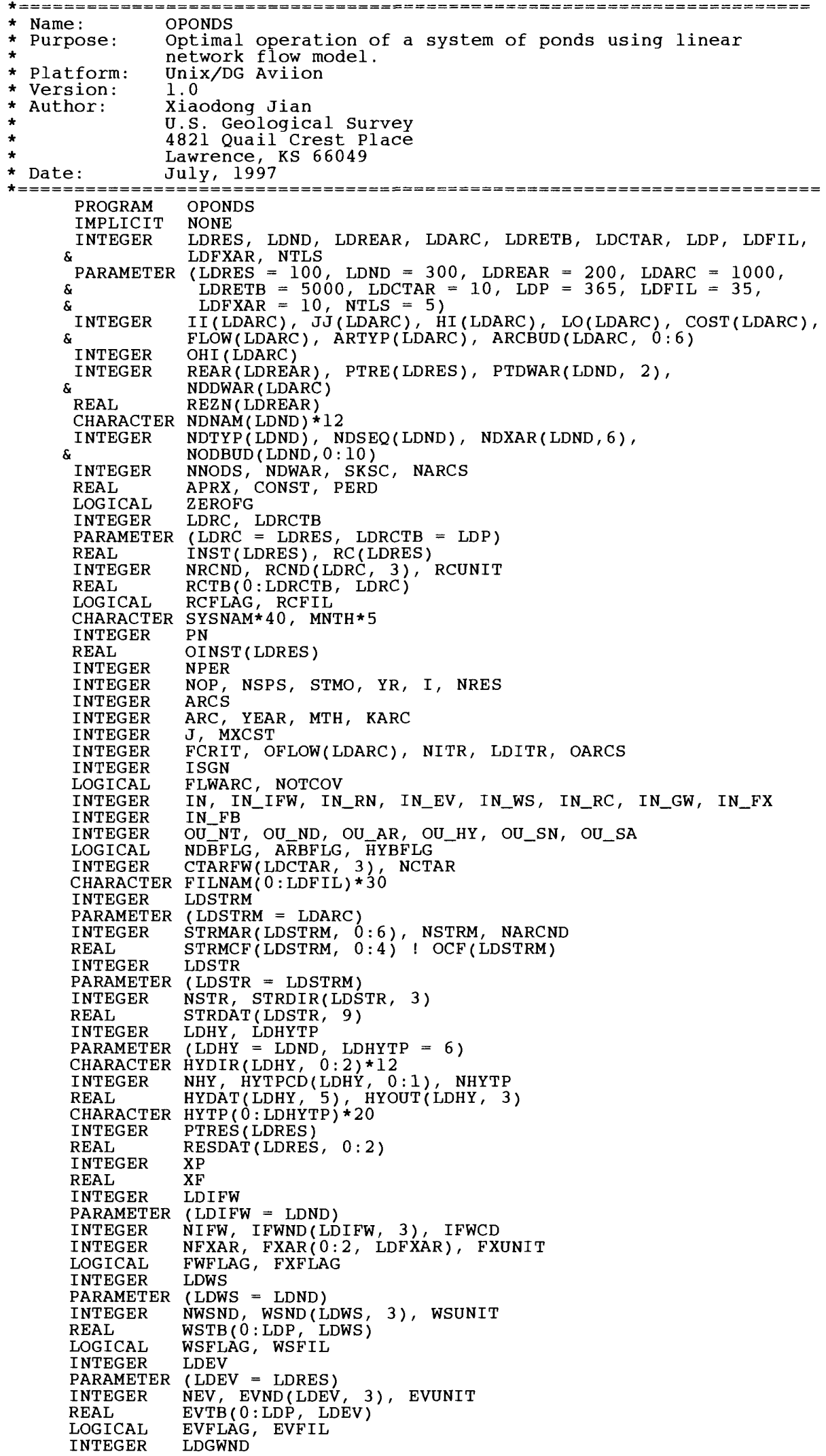




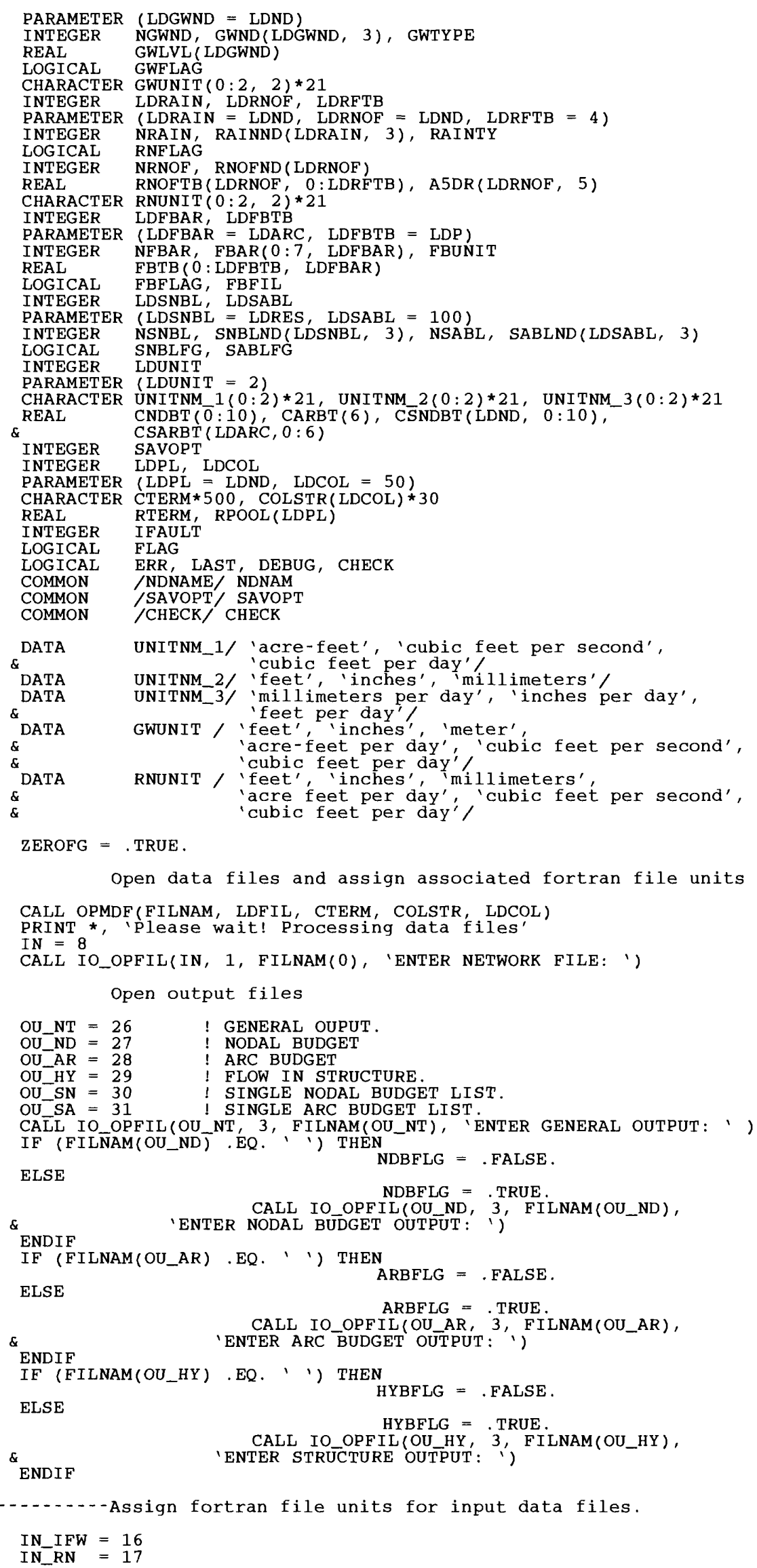




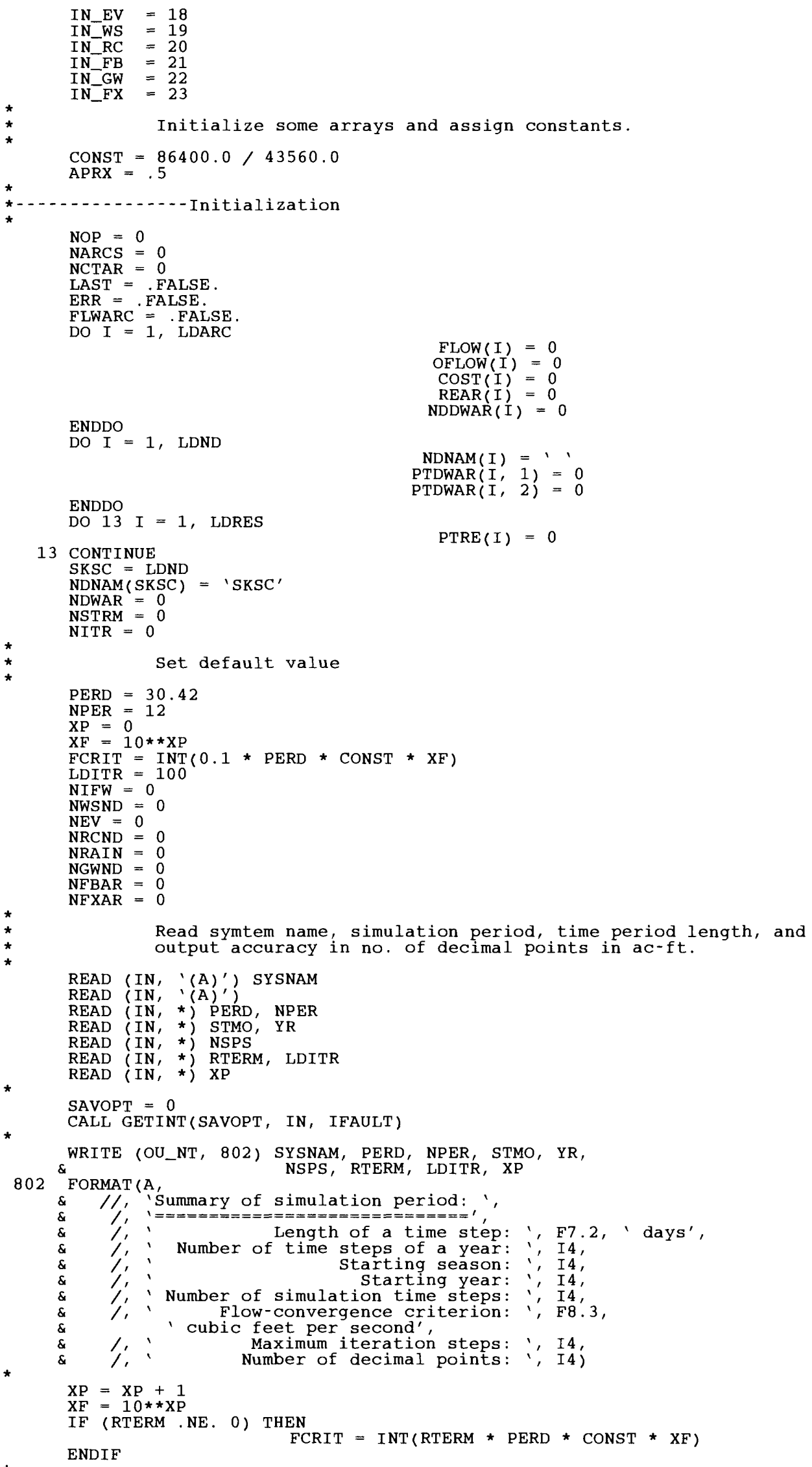




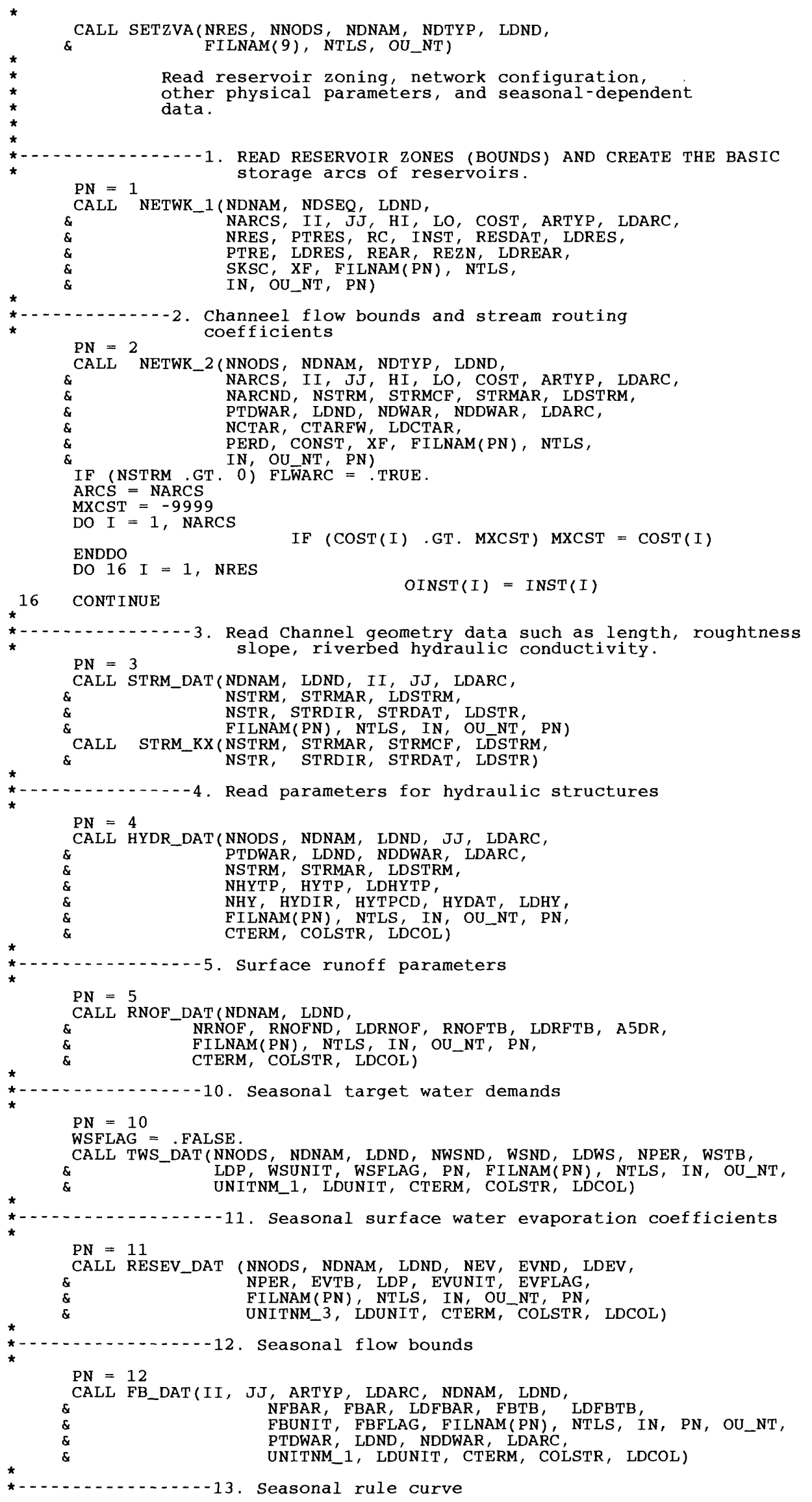




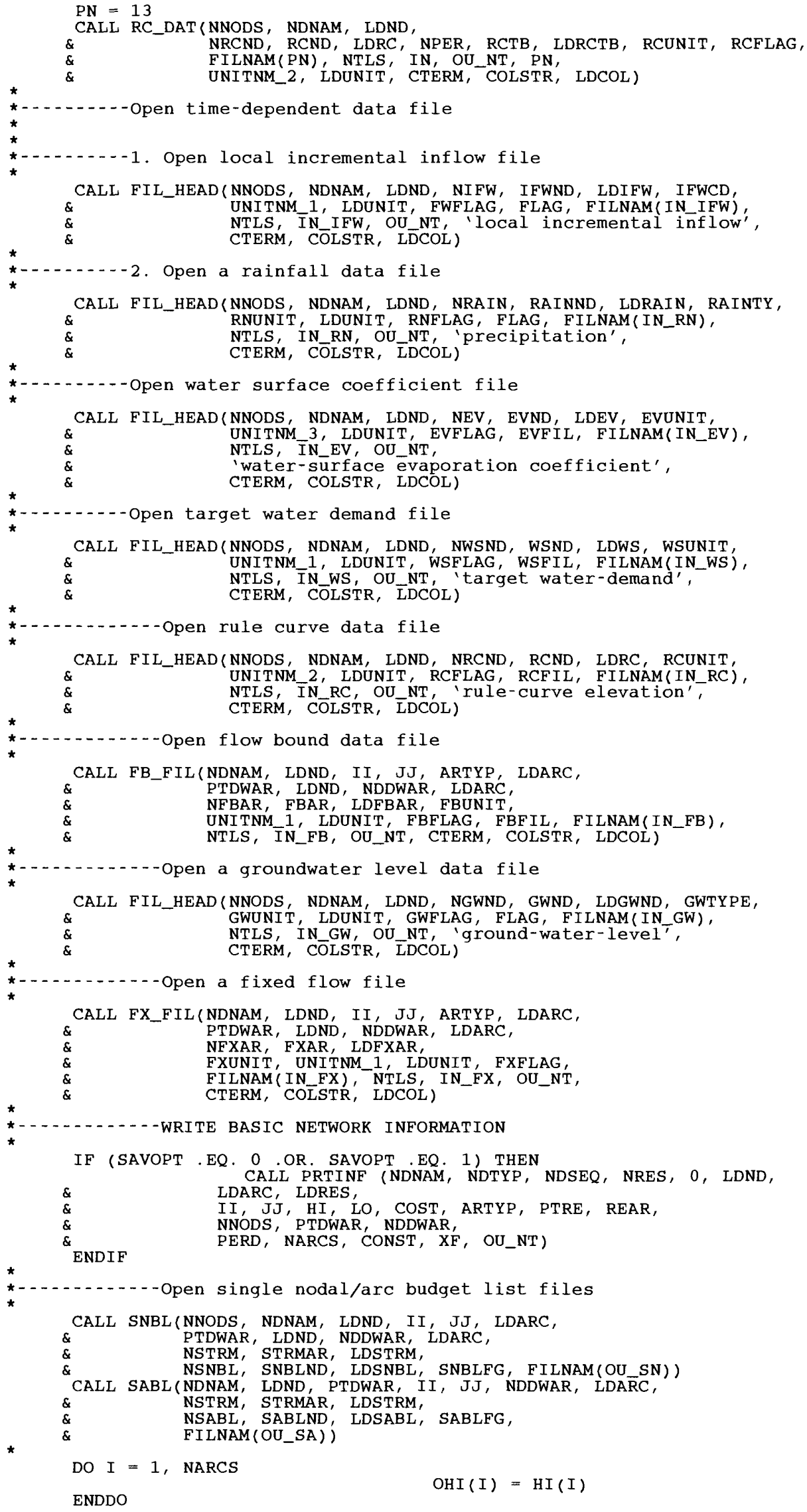




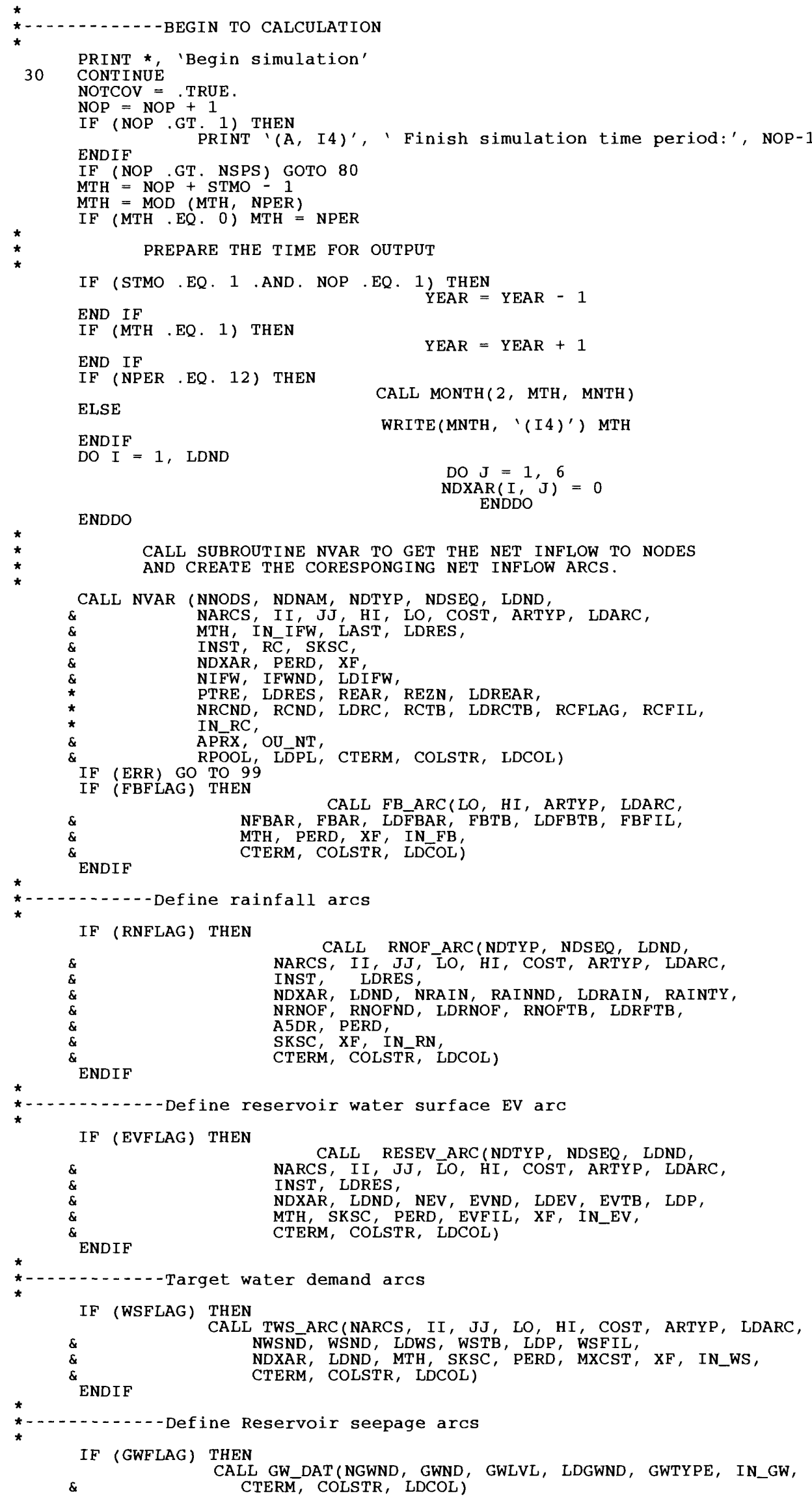




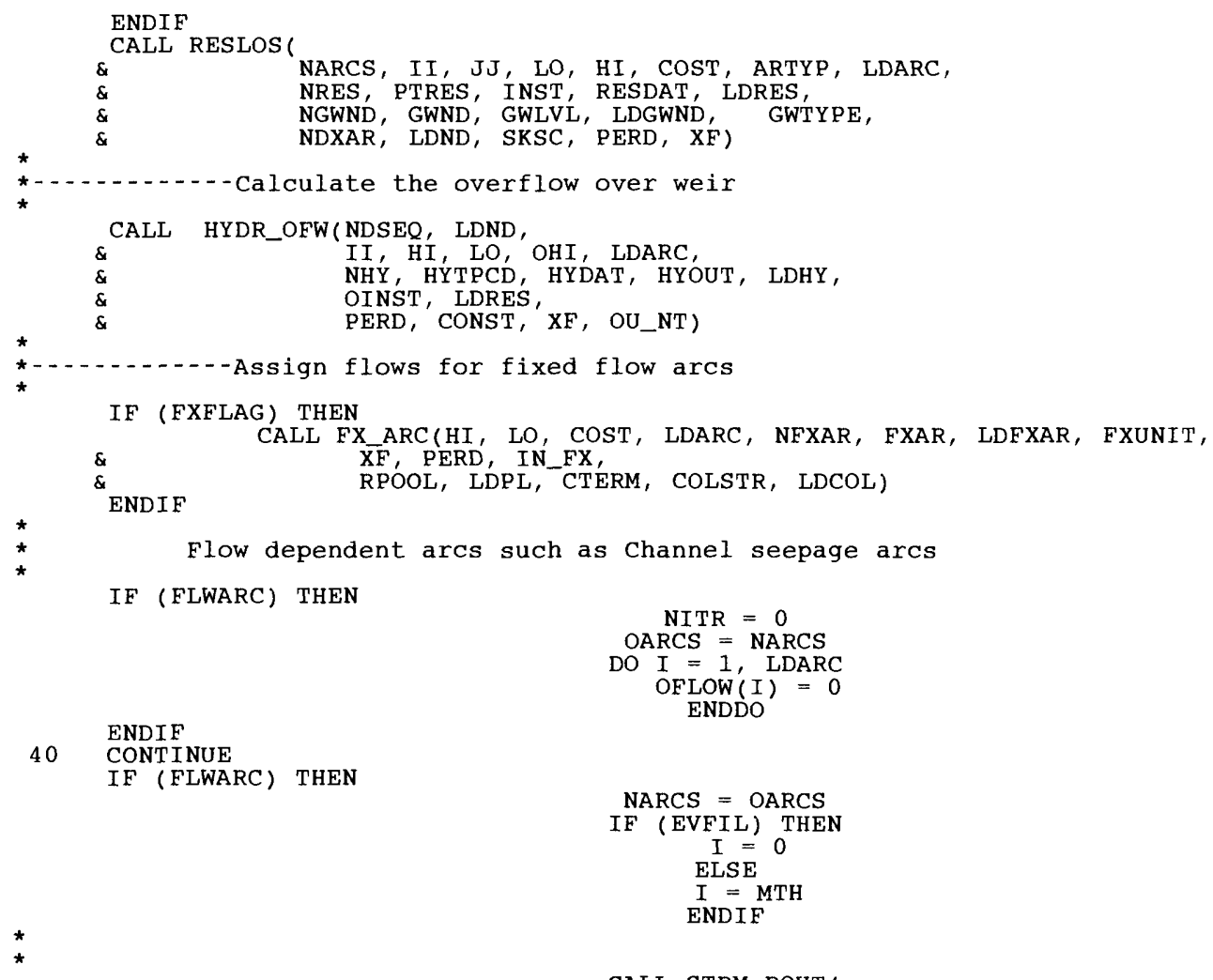

SOLVE THE NETWORK BY USING THE OUT OF KILTER TECHNIQUE

CALL KLTR(II, JJ, HI, LO, COST, FLOW, LDND, NARCS, DEBUG, KARC,

\& IF (IFAULT .NE. O) THEN

STOP IF (DEBUG) THEN
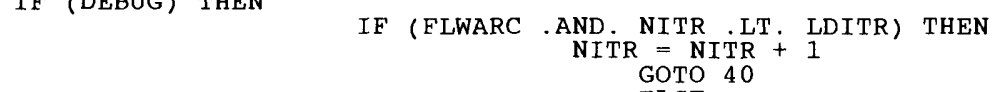


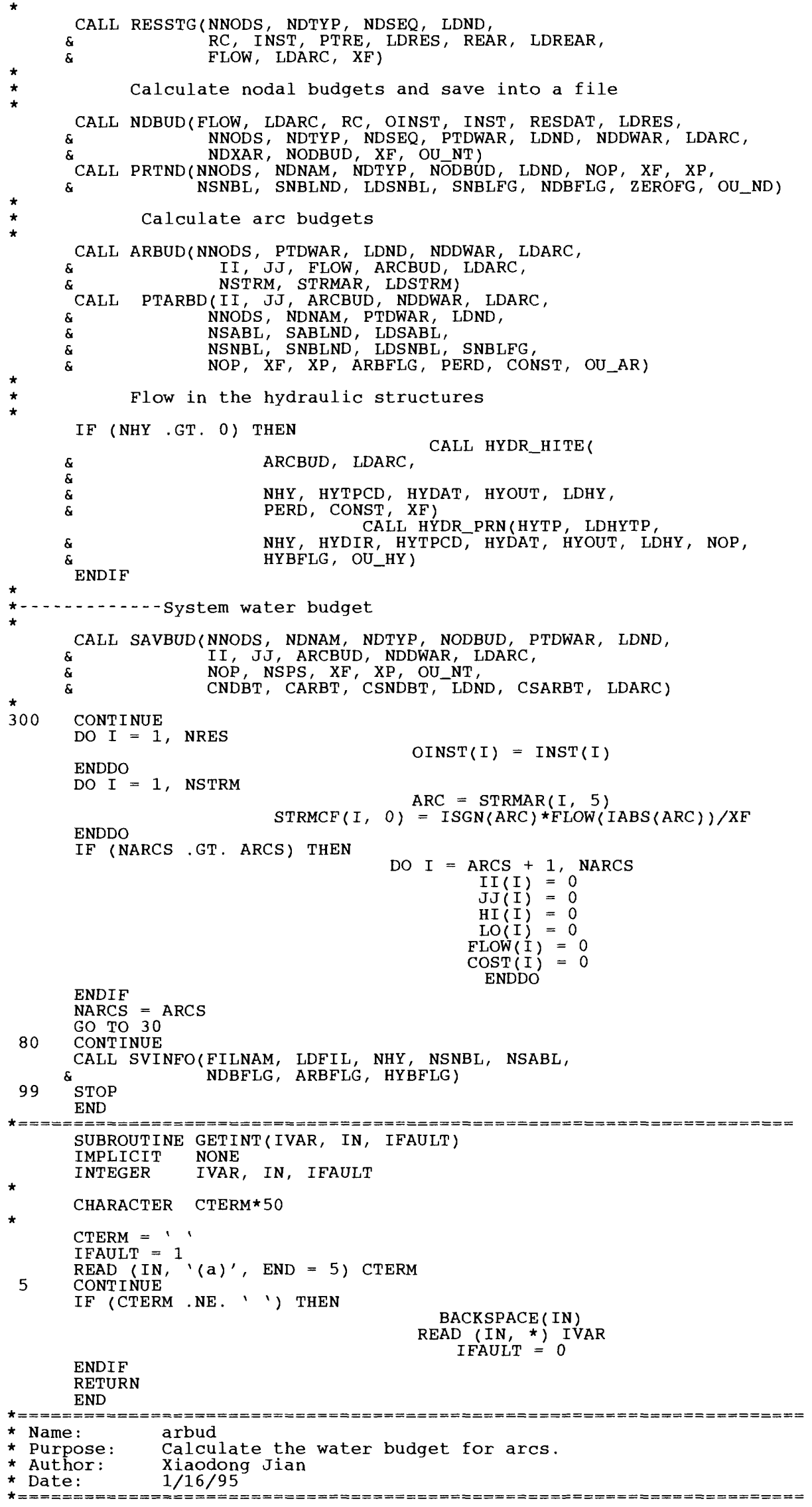

SUBROUTINE ARBUD(NND, PTDWAR, LDND, DWAR, LDDWAR, 
\& II, JJ, FLOW, ARCBUD, LDARC,

\& IMPIICIT NONE NSTRM, STRMAR, LDSTRM)

INTEGER NND, LDND, PTDWAR (LDND, 2), LDDWAR, DWAR (LDDWAR)

INTEG

NND, LDND' PTDWAR (LDND, 2)' LDDWAR, DWAR (LDDWAR)

$\&$

LDARC, II (LDARC), JJ (LDARC), FLOW (LDARC),

ARCBUD ( LDARC, $0: 6$ )

NSTRM， LDSTRM， STRMAR(LDSTRM， $0: 6$ )

INTEGER I，J， N， STRM， DWND， ARC， LIM1， LIM2， ARC2

INTEGER ISGN

LOGICAL UNSTRM

DO $100 \mathrm{~N}=1$, NND

$$
\begin{array}{r}
\operatorname{LIM1}=\operatorname{PTDWAR}(\mathrm{N}, 1) \\
\operatorname{LIM} 2=\operatorname{PTDWAR}(\mathrm{N}, 2) \\
\operatorname{DO} 50 \mathrm{~J}=\operatorname{LIM1}, \operatorname{LIM} 2 \\
\text { ARC }=\operatorname{DWAR}(\mathrm{J})
\end{array}
$$

Check if the current arc is a stream arc.

$\begin{aligned} \text { UNSTRM } & =i^{\text {TRUE }} . \\ I & =i\end{aligned}$

DO WHILE (I LE. NSTRM . AND UNSTRM)

IF (ARC.EQ. STRMAR(I, i)) THEN UNSTRM $=$.FALSE.

$$
\begin{gathered}
\text { STRM }=I \\
\text { ENDIF } \\
I=I+1 \\
\text { ENDDO }
\end{gathered}
$$

*-1. - - Calculate the arc water budget.

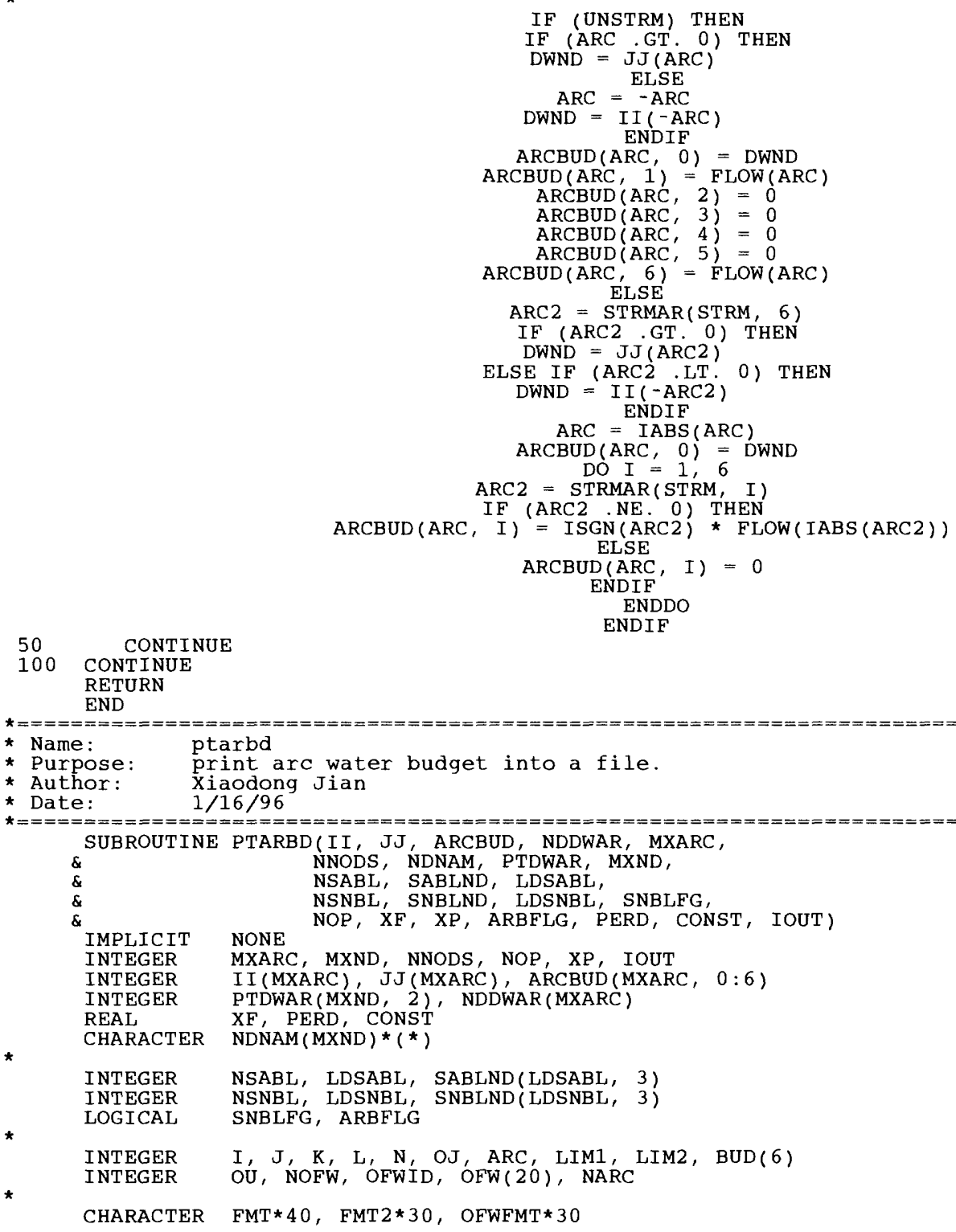

CHARACTER FMT*40, FMT2*30, OFWFMT*30 
LOGICAL OFWFLG, CN2INT, CNINT

NARC $=0$

IF (XP .GT. 0) THEN

$F M T='(I 4,1 \mathrm{X}, 2 \mathrm{~A} 12, \mathrm{~T} 30,6 \mathrm{~F} 10.0, \mathrm{~F} 10.2)^{\prime}$

WRITE'(FMT'(26:26), '(I1)') XP' - 1

FMT2 $=(\text { I4 }, 1 \mathrm{X}, 6 \mathrm{~F} 10.0, \mathrm{~F} 10.2)^{\prime}$

WRITE (FMT2 (15:15), '(I1)') XP - 1

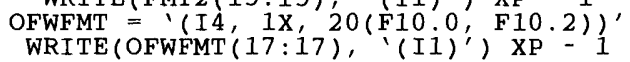

ELSE

$F M T='(I 4,1 X, 2 \mathrm{~A} 12, \mathrm{~T} 30,6 \mathrm{I} 10, \mathrm{~F} 10.2)^{\prime}$

$F M T 2='(I 4,1 X, 6 I 10, F 10.2){ }^{\prime}$

ENDIF

OFWFMT $=(\text { I } 4,1 \mathrm{X}, 20(\mathrm{I} 10, \mathrm{~F} 10.2))^{\prime}$

IF (ARBFLG) THEN

ENDIF

WRITE(IOUT, 900) NOP

DO $100 \mathrm{~N}=1$, NNODS

$$
\begin{aligned}
\operatorname{LIM1}= & \operatorname{PTDWAR}(\mathbf{N}, 1) \\
\operatorname{LIM} 2= & \operatorname{PTDWAR}(\mathbf{N}, 2) \\
& \text { OJ }=0
\end{aligned}
$$

*

IF (SNBLFG .AND. CNINT(N, NSNBL, SNBLND, OFWID)) THEN NOFW $=0$
OFWFLG $=$. TRUE. ELSE
OFWF $=$ ENDIF

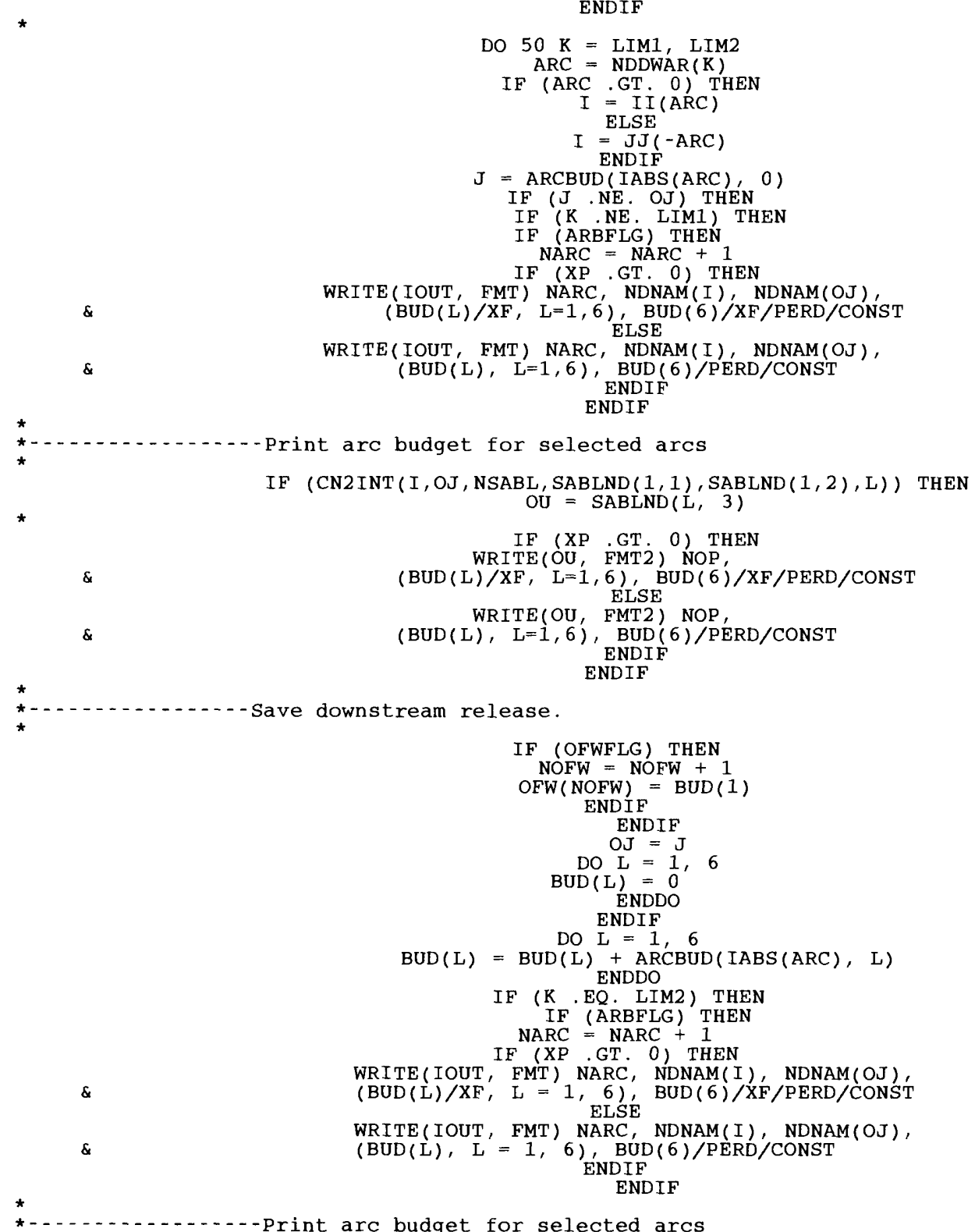




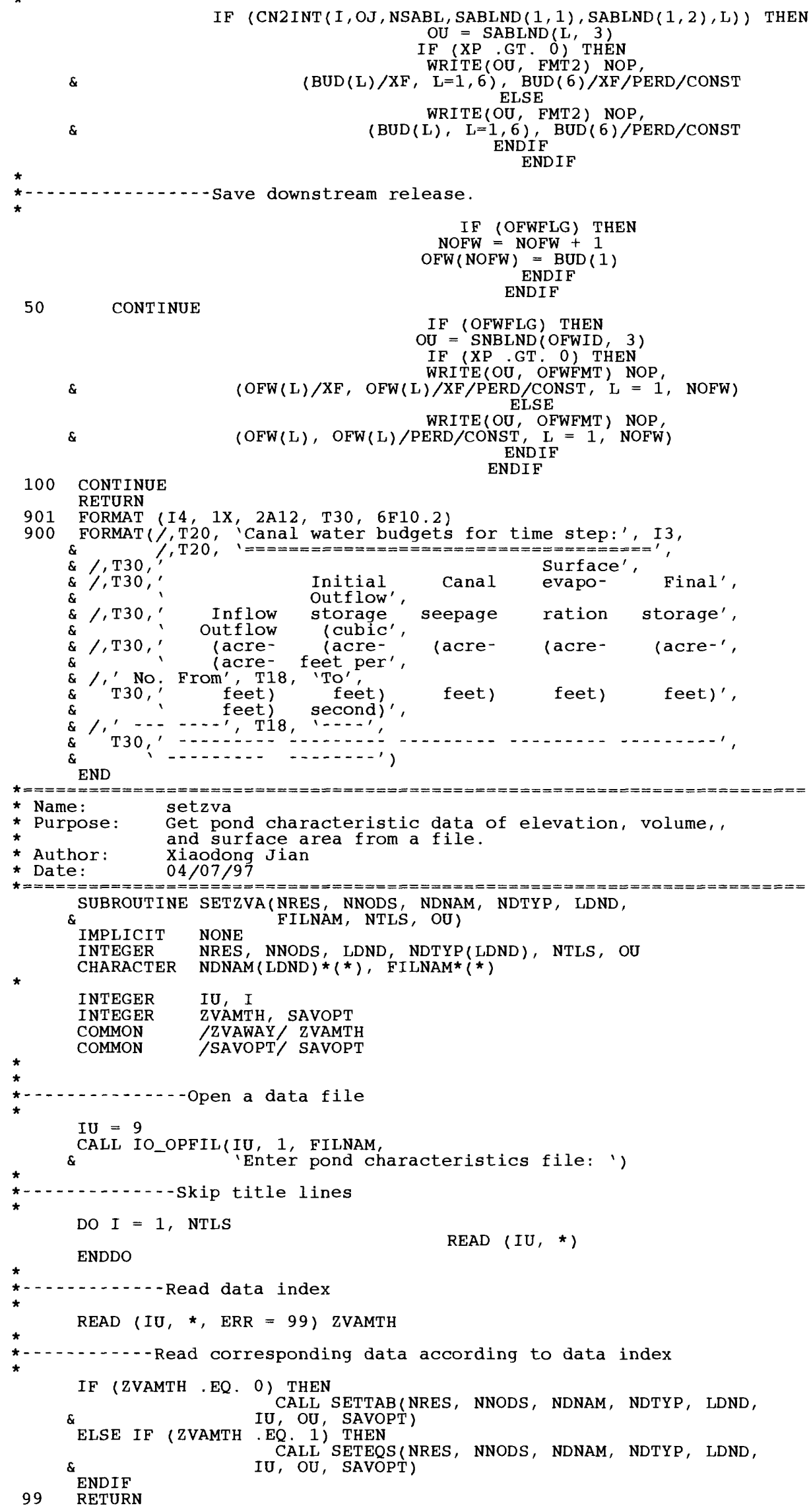

RETURN 


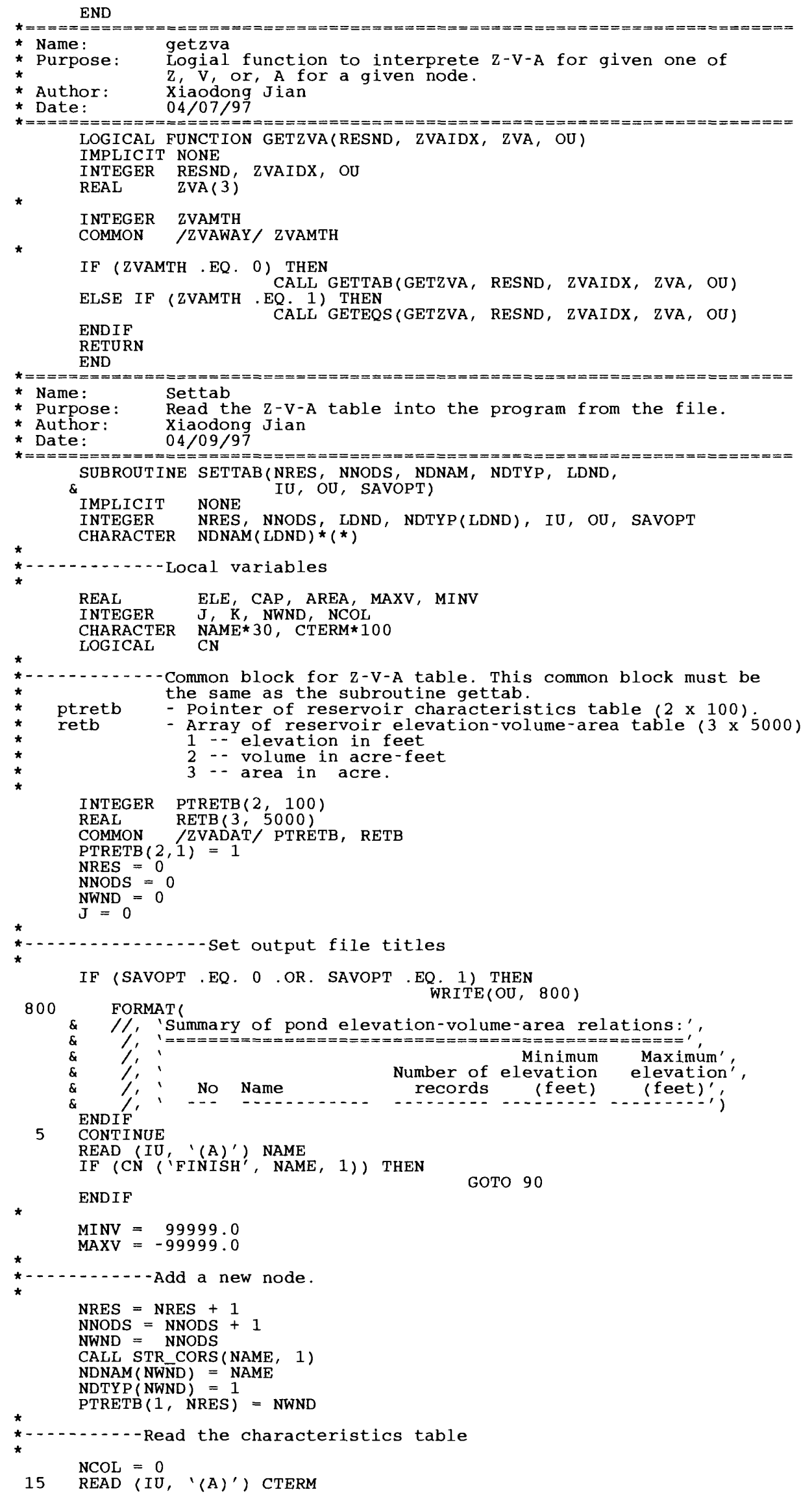


IF (CTERM . NE. ' ') THEN

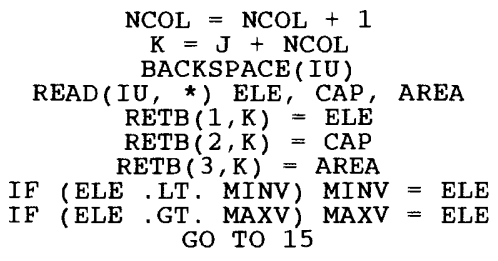

END IF

$\operatorname{PTRETB}(2, \operatorname{NRES}+1)=\operatorname{PTRETB}(2, \mathrm{NRES})+\mathrm{NCOL}$

$\mathrm{J}=\mathrm{J}+\mathrm{NCOL}$

IF (SAVOPT .EQ. 0 .OR. SAVOPT . EQ. 1) THEN

FORMAT(I5, 2X, WRITE (OU, 801) NRES, NAME, NCOL, MINV, MAXV ENDIF

GO TO 5

90 CONTINUE

CLOSE (IU)

RETURN

END

$\star$ Name:

* Name: gettab

Get the Z-V-A table to interprete the $\mathrm{Z} \sim \mathrm{V} \sim \mathrm{A}$ for a given

* node.

* Author: Xiaodong Jian

* Date: $4 / 9 / 97$

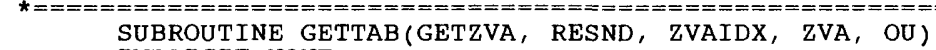

IMPLICIT NONE

INTEGER RESND, ZVAIDX, OU

REAL ZVA (3)

LOGICAL GETZVA

*

REAL $X, X 1, Y 1, X 2, Y 2, V A L, V A L 1, D I F$

INTEGER I, N, K, LIM

CHARACTER ZV́NÁ, Ĺ, LM

DATA $\quad$ ZVANAM/ 'ELEVATION', 'VOLUME', 'AREA'/

* -...-..-- Common block for Z-V-A table. This common block must be the same as the subroutine settab.

INTEGER PTRETB $(2,100)$

$\begin{array}{ll}\text { REAL } & \operatorname{RETB}(3,5000) \\ \text { CHARACTER } & \operatorname{NDNAM}(300) * 12\end{array}$

CHARACTER NDNAM $(300) * 12$

COMMON /ZVADAT/ PTRETB， RETB

COMMON /NDNAME/ NDNAM

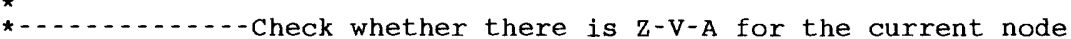

$\mathrm{N}=1$

DO WHILE (PTRETB $(1, N) . N E . \operatorname{RESND} . \underset{\mathbf{N}}{\operatorname{AND}}=\underset{\mathbf{N}+1}{\operatorname{PTRETB}}(1, \mathbf{N}) . N E .0)$

ENDDO

IF (PTRETB $(1, N)$. NE. RESND) THEN

\section{ENDIF}

GETZVA $=$. FALSE

GOTO 99

GETZVA = TRUE.

$\mathrm{K}=\operatorname{PTRETB}(2, N)$
$\mathrm{LIM}=\operatorname{PTRETB}(2, \mathrm{~N}+1)-1$

VAL = ZVA (ZVAIDX)

IF (VAL . LT. 0) VAL $=0.0$

IF (RETB (ZVAIDX, K) .GT. VAL . OR. RETB(ZVAIDX, LIM) .LT. VAL) THEN GETZVA $=$. FALSE

PRINT, (A), CHAR $(7)$

CALL STR LEN (ZVANAM (ZVAIDX)

WRITE (OU, 901) ZVANAM(ZVAIDX) ( $1:$ I), VAL, NDNAM(RESND), RESND, ZVANAM (ZVAIDX) ( $1: I), \operatorname{RETB}($ ZVAIDX, K),

WRITE ( * ZVANAM (ZVAIDX) ( 1 : I)', RETB (ZVAIDX, LIM)

901) ZVANAM ( ZVAIDX) ( 1 : I) V' VAL, NDNAM ZVANAM (ZVAIDX) ( $1: I)$, RETB (ZVAIDX, LIM)

901

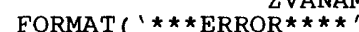

1,1 TRANSFORMING $', \mathrm{~A}, 1=1, \mathrm{~F} 10.2$

$\%$, TO ITS CORRESPONDING PARAMETERS AT POND: ', A,

$\%$, WITH THE NODAL NUMBER: ', I2,

', THE MINIMUM ', A, I IN Z-V-A'TABLE $=1, F 10.2$,

;, THE MAXIMUM ', A, I IN Z-V-A TABLE $=$ ', F10.2

goto 99

10 ENDIF

CONTINUE

VAL1 $=$ RETB $($ ZVAIDX, $K)$

$\mathrm{DIF}=\mathrm{VAL} 1-\mathrm{VAL}$

IF (DIF . LT. 0) THEN

IF ( $K$. GT . LIM) THEN

GETZVA $=$. FALSE. 


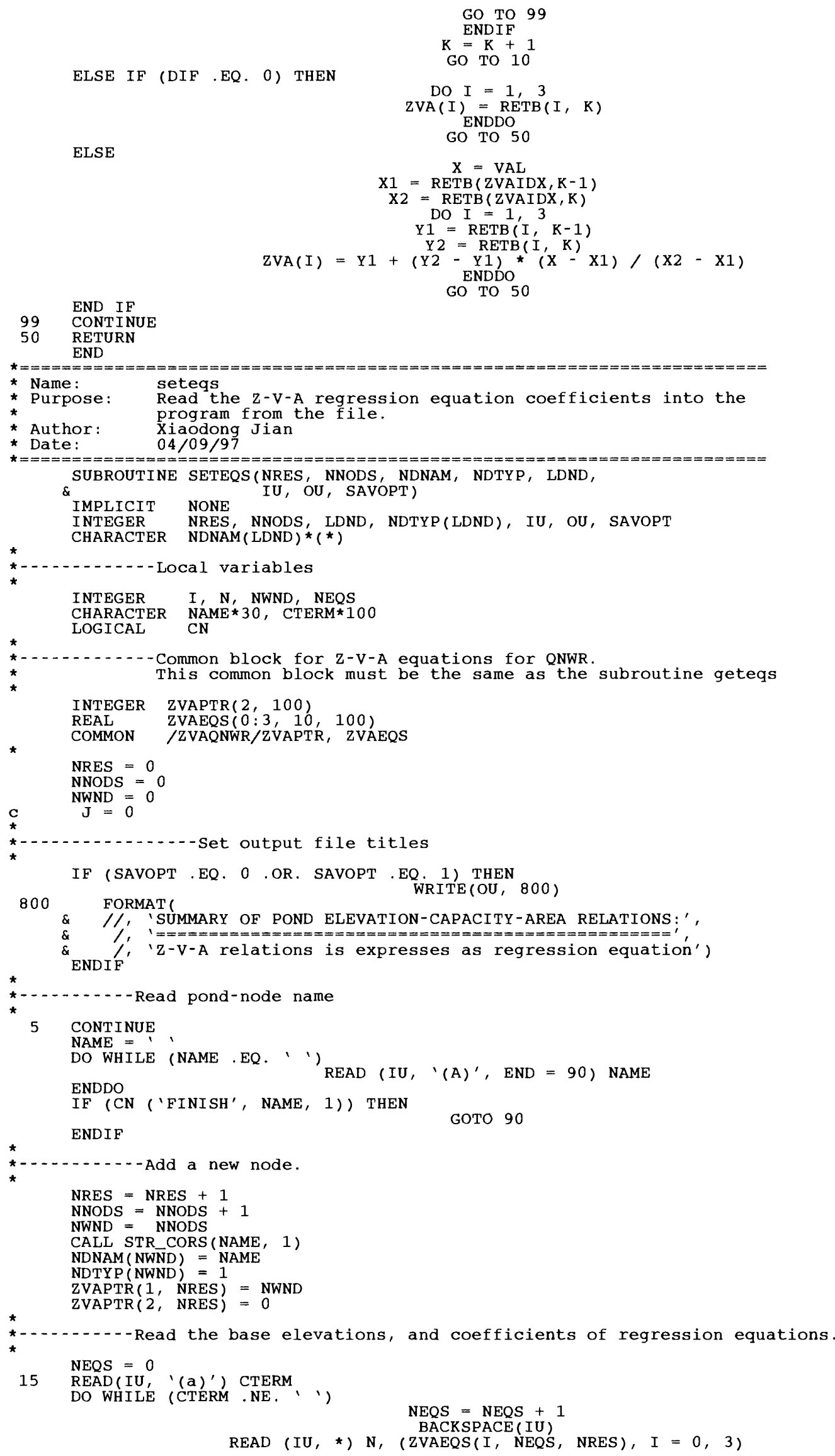

ELSE$$
\mathrm{X}=\mathrm{VAL}
$$$$
\mathrm{X} 1=\operatorname{RETB}(\text { ZVAIDX, } \mathrm{K}-1)
$$$$
\mathrm{X} 2=\operatorname{RETB}(\mathrm{ZVAIDX}, \mathrm{K} \text { ) }
$$$$
\text { DO I }=1,3
$$$$
\mathrm{Y} 1=\operatorname{RETB}(\mathrm{I}, \mathrm{K}-1)
$$$$
\mathrm{ZVA}(\mathrm{I})=\mathrm{Y} 1+\underset{\mathrm{Y} 2}{(\mathrm{Y} 2-\mathrm{YETB}(\mathrm{I} 1) * \mathrm{~K})}(\mathrm{X}-\mathrm{X} 1) /(\mathrm{X} 2-\mathrm{X} 1)
$$$$
\text { GO TO } 50
$$

END IF

CONTINUE

50 RETURN

END

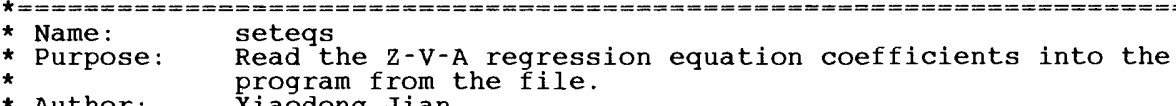

* Author: Xiaodong Jian

* Date: 04/09/97

SUBROUTINE SETEQS(NRES, NNODS, NDNAM, NDTYP, LDND,

IMPLICIT NONE IU, OU, SAVOPT)

INTEGER NRES， NNODS， LDND， NDTYP(LDND)， IU， OU， SAVOPT

*-.......-. Local variables

* integer i, N, NWND, NEQS

CHARACTER NAME $* 30$, CTERM $* 100$

LOGICAL CN

*-........-Common block for Z-V-A equations for QNWR.

This common block must be the same as the subroutine geteqs

INTEGER ZVAPTR $(2,100)$

REAL ZVAEQS $(0: 3,10,100)$

COMMON /ZVAQNWR/ZVAPTR, ZVAEQS

* NRES $=0$

NRES $=0$
NNODS $=0$

$N W N D=0$

c

(1)-set output file titles

IF (SAVOPT .EQ. 0 .OR. SAVOPT .EQ. 1) THEN

W00 WRITE(OU, 800)

800 \& FORMAT' $/ /$, SUMMARY OF POND ELEVATION-CAPACITY-AREA RELATIONS:'

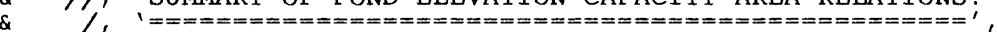

\& $f-v-A$ relations is expresses as regression equation')

*-...-.-.-Read pond-node name

5 CONTINUE

$\mathrm{NAME}=$

DO WHILE (NAME .EQ. ' ' ' READ (IU, ' (A)', END $=90$ ) NAME

ENDDO

IF (CN ('FINISH', NAME, 1)) THEN

ENDIF

GOTO 90

*............... Add a new node.

NRES $=$ NRES +1

NNODS $=$ NNODS +1

NWND $=$ NNODS

CALL STR_CORS (NAME， 1)

$\operatorname{NDNAM}(\operatorname{NWN} D)=N A M E$

NDTYP (NWND) $=1$

$\operatorname{ZVAPTR}(1, \operatorname{NRES})=$ NWND

$\operatorname{ZVAPTR}(2, \operatorname{NRES})=0$

*

NEOS $=0$

15 READ (IU, ' (a)') CTERM

DO WHILE (CTERM .NE.' ')

$\mathrm{NEQS}=\mathrm{NEQS}+1$

READ (IU, *) N， (ZVAEQS(I, NEQS, NRES), I $=0,3$ ) 
READ (IU, '(a)', END= 20) CTERM

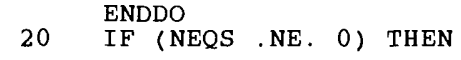

ENDIF

*

GOTO 5

* 90 CONTINUE CLOSE (IU)
RETURN END

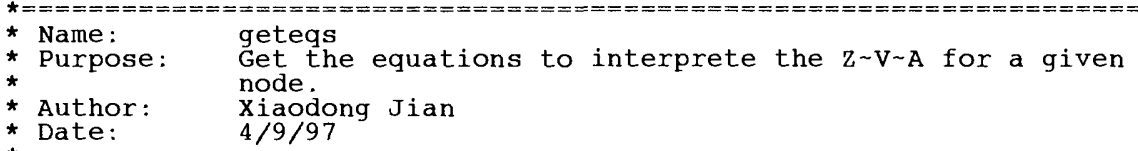


ENDDO

$\mathrm{Z} 2=\mathrm{ZVA}(1)$

* - . . - - Binary search for the elevation.

DO WHILE(ABS ( $Z 2-\mathrm{Z} 1), \mathrm{GT}, 0.005)$

$\mathrm{ZVA}(1)=0.5 *(\dot{\mathrm{Z} 1}+\mathrm{z} 2)$

CALL Z2VA (NEOS, A, ZVA, IERR)

IF (ZVA (ZVAIDX) . LT. VAL) THEN

ELSE IF (ZVA(ZVAIDX) G GT. VAL) THEN $\mathrm{Z} 2=\mathrm{ZVA}(1)$

ELSE

GOTO 100

ENDIF

ENDIF

ENDDO

100 CONTINUE

DO $I=1,3$

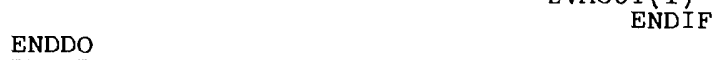

*

IERR $=1$

99 RETURN END

* Name: chdep

* Purpose: Compute depth of flow using Manning's Equation

* Author: Xiaodong Jian

* Date: $\quad 5 / 9 / 96$

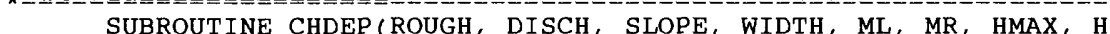
IMPLICIT NONE REAL ROUGH, DISCH, SLOPE, WIDTH, ML, MR, HMAX, H, TOL, $\&$ INTEGER IERR, ITMX

* REAL INTEGER DATA $\mathrm{H} 1, \mathrm{H} 2$, AREA, RAD, C, C1, EPS EPS /0.000001/

IERR $=0$ IF (DISCH . LT. EPS) THEN

ENDIF

$$
\mathrm{H}=0.0
$$

*

$\mathrm{C}=\mathrm{ROUGH} * \mathrm{DISCH} / \mathrm{SQRT}(\mathrm{SLOPE}) / \mathrm{CONST}$

$\mathrm{H} 1=\mathrm{HMAX}$

$\mathrm{H}=\mathrm{H} 1$

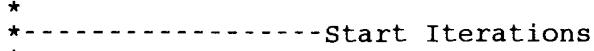

$\mathrm{IERR}=0$

DO $100 I=1$, I TMX

compue area and hydraulic radius

AREA $=\mathrm{H} *($ WIDTH $+0.5 * \mathrm{H} *(\mathrm{ML}+\mathrm{MR}))$ $\mathrm{RAD}=\mathrm{AREA} /\left(\mathrm{WIDTH}+\mathrm{H}^{\star}(\operatorname{SQRT}(1.0+\mathrm{ML} \star \mathrm{ML})+\operatorname{SQRT}(1.0+\mathrm{MR} \star \mathrm{MR}))\right)$ Compute approximate quotient

$\mathrm{Cl}=\mathrm{AREA} * \mathrm{RAD} * \star(2.0 / 3.0)$

Check convergence

IF (ABS ( (C1-C)/C) GE. TOL) THEN ENDIF 
if No.

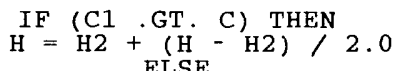

$$
\begin{aligned}
& \text { IF (H+EPS.GE. H1) THEN } \\
& \begin{array}{l}
\text { IERR }=1 \\
\mathrm{H} 1=\mathrm{H} 1 * 2
\end{array} \\
& \text { ELSE } \\
& \begin{array}{l}
\mathrm{ELSE} \\
\mathrm{H} 2=\mathrm{H}
\end{array} \\
& \mathrm{H}=\mathrm{H} 2+(\mathrm{H} 1-\mathrm{H} 2) / 2.0 \\
& \text { ENDIF }
\end{aligned}
$$

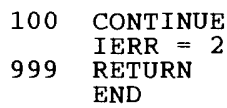$$
\star======
$$$$
\text { * Name: fil_head }
$$

* Purpose: Open a time series file and read headers for nodal data.

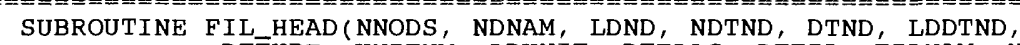

\& DTTYPE, UNITNM, LDUNIT, DTFLAG, DTFIL, FILNAM, NTLS,

\& IMPLICIT IU, OU, CLASS, CTERM, COLSTR, LDCOL) INTEGER NNODS, LDND， NDTND， LDDTND， DTND(LDDTND，3)， DTTYPE,

$\&$

CHARACTER* $(*)$ NDNAM(LDND), UNITNM(0:LDUNIT, 1$),$ FILNAM, CLASS

INTEGER NTLS, IU, OU

LOGICAL DTFLAG, DTFIL

INTEGER LDCOL

CHARACTER CTERM* $(*), \operatorname{COLSTR}(\operatorname{LDCOL}) *(*), \operatorname{MESS} * 50$

INTEGER DTUNIT

INTEGER $\mathrm{I} ， \mathrm{~J}, \mathrm{~K}, \mathrm{~L}, \mathrm{~N}, \mathrm{ND}, \mathrm{NREC}, \mathrm{NNDS}$ ， SL

LOGICAL ERR, CN, CNINT, DUMMY, ISNUM

INTEGER SAVOPT

COMMON /SAVOPT/ SAVOPT

DTTYPE $=1$

DUMMY $=$.FALSE

MESS = 'ENTER DATA FILE FOR $1 / /$ CLASS

DTFIL $=$.FALSE

IF (FILNAM . EQ. ' ') THEN

ENDIF

GOTO 999

CALL IO_OPFIL (IU, 1, FILNAM, MESS)

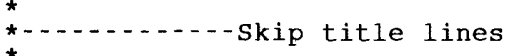

DO $I=1$, NTLS

ENDDO

READ (IU, *, END = 999)

\section{*-.. - - -2-Read data unit code and type}

READ (IU, ' (A)', END $=999$ ) CTERM

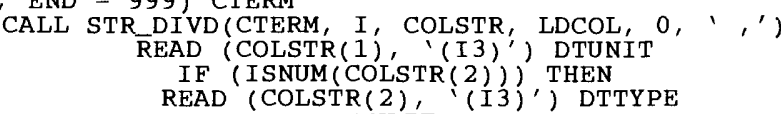

NNDS $=0$

READ (IU, ' $(A)^{\prime}$, , END = 999) CTERM

CALL STR_DIVD(CTERM, NNDS, COLSTR, LDCOL, $0,{ }^{\prime},{ }^{\prime}$ )

$\mathrm{N}=0$

DO $30 \mathrm{I}=2$, NNDS

IF (CN(COLSTR(I), 'DEFAULT', 1)) THEN

*-...-.-.-seasonal data are no longer valid.

DUMMY $=$. TRUE.

IF (NNDS . EQ. 2) THEN

DO $\mathrm{J}=1$, NNODS

$\operatorname{DTND}(\mathrm{J}, 1)=\mathrm{J}$

$\operatorname{DTND}(J, 2)=$ DTUNIT

$\operatorname{DTND}(\mathrm{J}, 3)=-\mathrm{J}$

ELSE

IF (NDTND .GT. 0) THEN

DO $25 \mathrm{~J}=1$, NNDS - 2

IF (DTND (L, 3). EQ. J) THEN

DO $\mathrm{K}=1,3$

$\operatorname{DTND}(\mathrm{J}, \underset{\mathrm{ENDDO}}{\mathrm{K}})=\operatorname{DTND}(\mathrm{L}, \mathrm{K})$ 


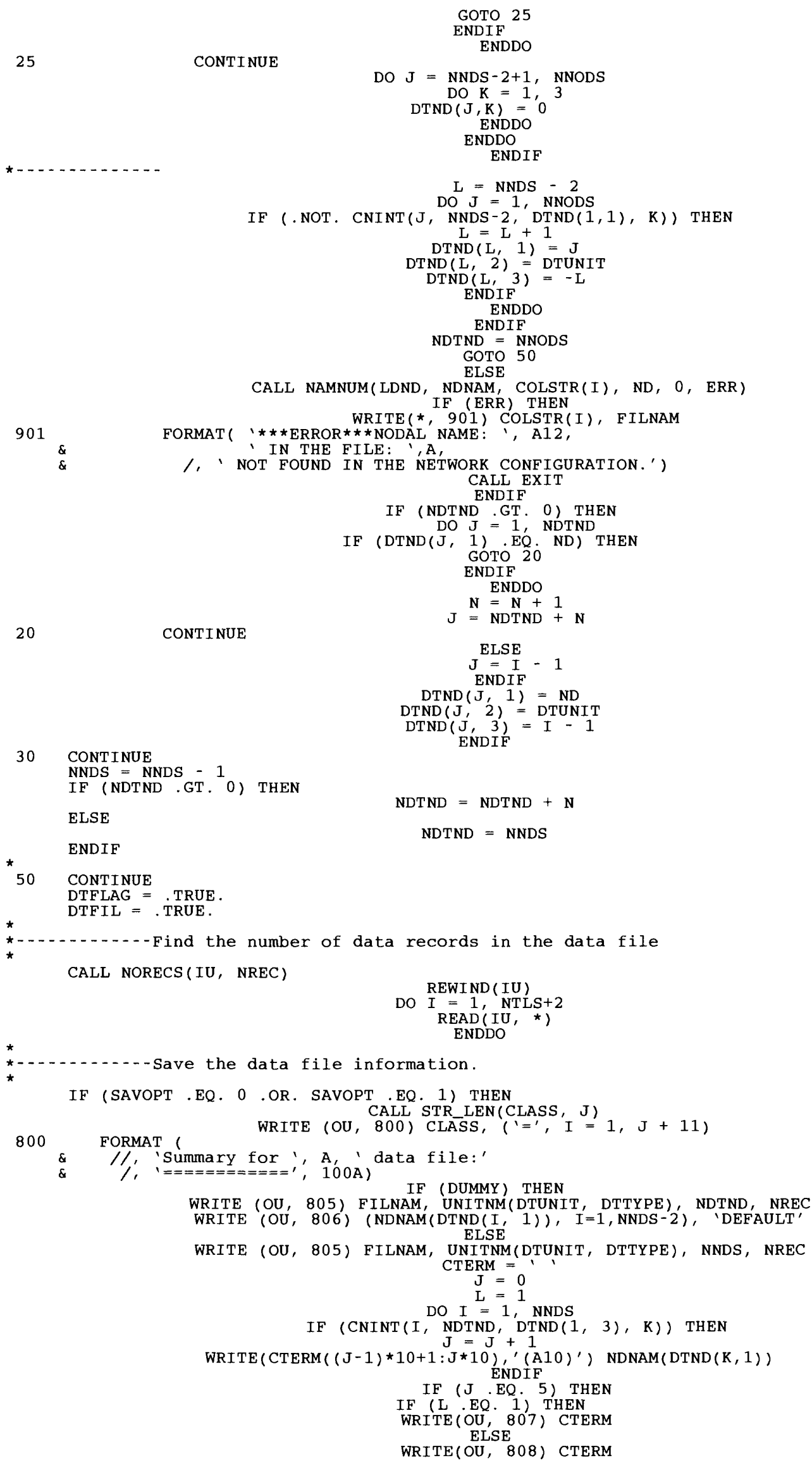


ENDIF

$$
\begin{aligned}
& \text { ENDIF } \\
& \text { CTERM }= \\
& \mathrm{J}=0 \\
& =\underset{\text { ENDIF }}{\mathrm{L}+1} \\
& \text { ENDDO } \\
& \text { IF (SL (CTERM) .GT . O ) THEN } \\
& \text { IF (L .EQ i) THEN } \\
& \text { WRITE (OU， 807) CTERM } \\
& \text { ELSE } \\
& \text { WRITE (OU， 808) CTERM } \\
& \text { ENDIF } \\
& \text { CTERM }=\text {, , } \\
& \text { ENDIF } \\
& \text { ENDIF }
\end{aligned}
$$

RETURN

$$
\text { FORMAT }
$$

$\& \quad /, 10 \mathrm{x}$; File name:, $\mathrm{A}$

$\& \quad /, 10 \mathrm{x}$, Data unit: $\because \mathrm{A}$

$\& \quad$, 10X, Number of nodes: ', I4,

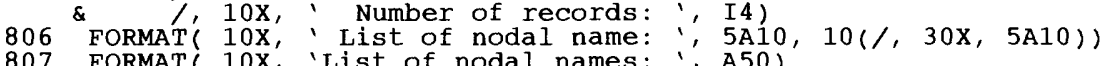

807 FORMAT (10X, 'List of nodal names: ', A50)

808 FORMAT ( 31X, A50)

END

SUBROUTINE NORECS (IU, NREC)

IMPLICIT NONE

INTEGER IU, NREC, I

* $\quad$ NREC $=0$

$5 \quad$ READ (IU, * END $=10$ )

NREC $=$ NREC +1

NREC $=$

DOT I $=1, \quad \mathrm{NREC}+1$

10

ENDDO

BACKSPACE ( IU )

RETURN

END

$*==========$

* Purpose: Check whether a string is a float or integer number.

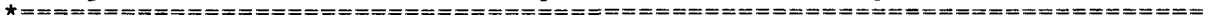
LOGICAL FUNCTION ISNUM(STR)

IMPLICIT NONE

CHARACTER STR* (*)

INTEGER I， L， ICD

LOGICAL DECFLG, SIGNFG

$I S N U M=. F A L S E$.

DECFLG $=$. FALSE.

SIGNFG $=$.FALSE

IF (STR . EQ. ' ) GOTO 999

$\mathrm{L}=\operatorname{LEN}(\mathrm{STR})$

DO $I=1, I$

IF ( $\operatorname{STR}(I: I) . N E$. ' ') THEN

$\operatorname{ICD}=\operatorname{ICHAR}(\operatorname{STR}(I: I))$

IF (ICD.GE. 48 . AND. ICD. LE. 57) THEN I DIGITS 0 - 9.

ELSE IF (ICD .EQ. 46 . AND. CONTINUE DECFLG $=$. TRUE

ELSE IF ( (ICD .EQ. 43 .OR. ICD . EQ. 45)

AND. .NOT. SIGNFG) THEN ! + OR - TRUE

ELSE

GOTO 999

ENDIF

ENDIF

ENDDO

ISNUM $=$. TRUE

999

RETURN

END

LOGICAL FUNCTION INLIST(ND, NLST, LSTND, LOC)

IMPLICIT NONE

INTEGER ND， NLST，LSTND(NLST)， LOC

INTEGER I

INLIST $=$. FALSE

DO $I=1, \quad$ NLST

IF (ND . EQ. LSTND(I) ) THEN

INLIST $=$. TRUE .

GOTO 999

999 ENDDO

ENDIF

END

* Name: gw_dat

* Purpose: Read groundwater altitude or flux data.

* Author: Xiaodong Jian 


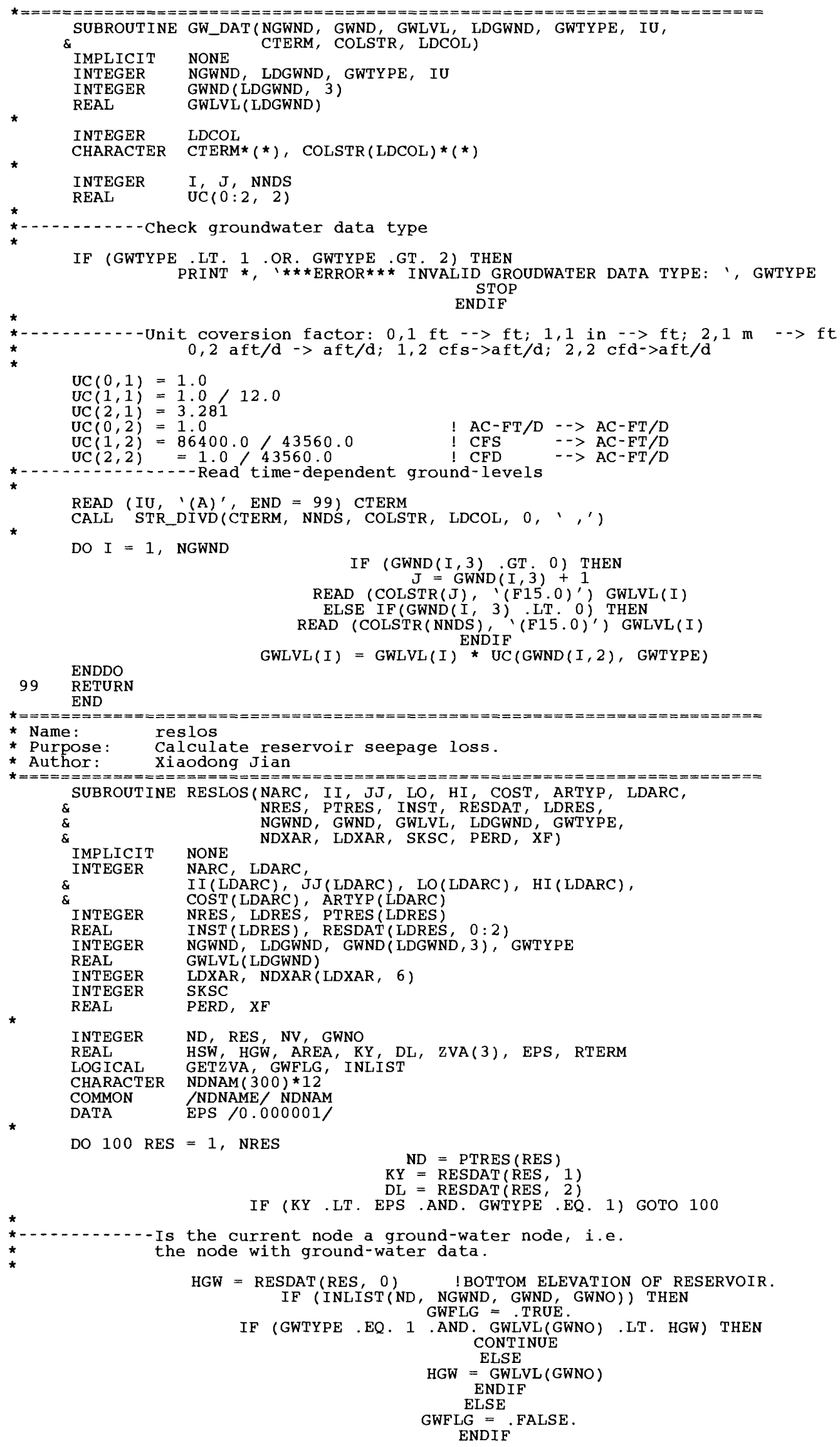




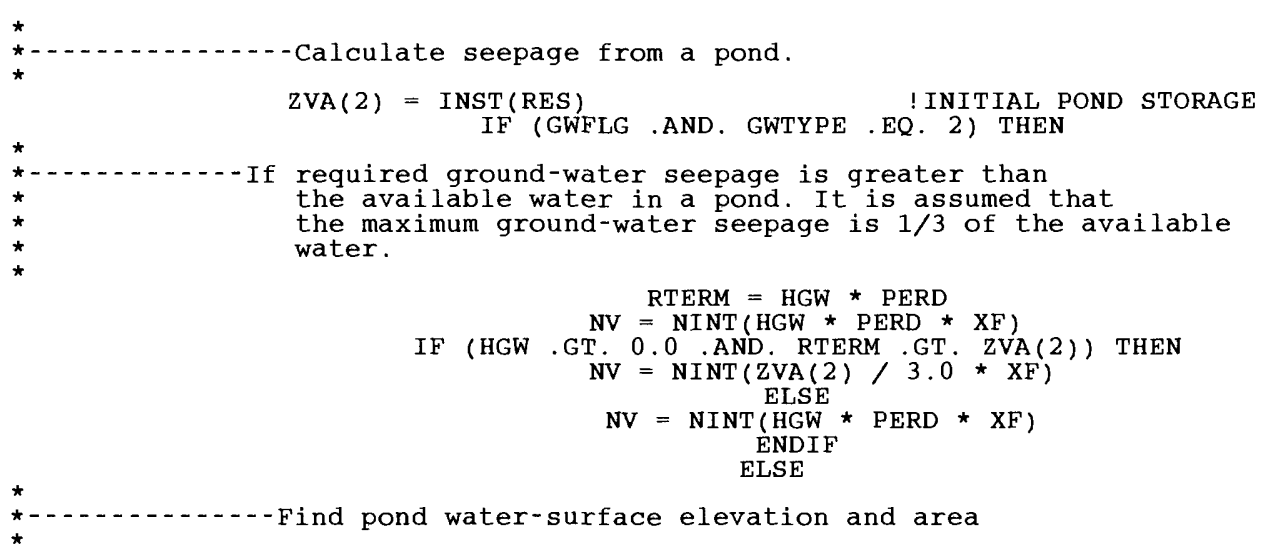


ENDDO ENDIF

DO $1 \mathrm{~A}=1$, NARCS

1

CONTINUE

DO $2 M=0$, NNODS

CONTINUE

DO $3 \mathrm{~K}=0,100$

3

CONTINUE

DO $4 \mathrm{~A}=1$, NARCS

$$
\text { FLOW }(A)=0
$$

$\mathrm{PI}(\mathrm{M})=0$

$\mathrm{NA}(\mathrm{K})=0$

$\varepsilon$

IF (LO (A) $\underset{\text { IFAULT }}{\text { GGT }}=1$

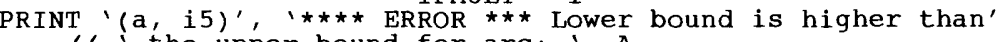
// the upper bound for arc: ', A

PRINT (a, i10),' The lower bound is ', LO(A)

PRINT ' $(a, i 10)$ ', ' The upper bound is ', HI(A)

CONTINUE

END IF

IF (IFAULT . NE. O) THEN

ENDIF

$\mathrm{INF}=999999$

$\mathrm{AOK}=0$

10 CONTINUE

DO $20 A=1$, NARCS

RETURN

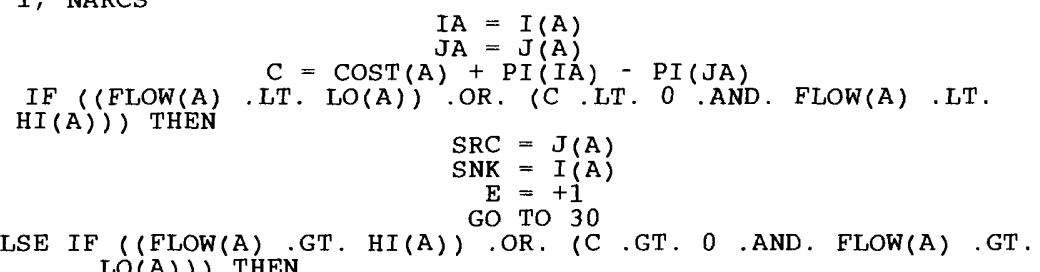

$$
\begin{aligned}
& S R C=I(A) \\
& S N K=J(A) \\
& E=-1 \\
& \text { GO TO } 30 \\
& \text { END IF }
\end{aligned}
$$

20 CONTINUE

30 IF ((A.EQ. AOK) .AND. (NA(SRC).NE. 0)) GO TO 25

DOK $5 N^{A}=1$, NNODS

5 CONTINUE

$\mathrm{NA}(\mathrm{SRC})=\operatorname{IABS}(\mathrm{SNK}) * \mathrm{E}$

$\mathrm{NB}(\mathrm{SRC})=\operatorname{IABS}(\mathrm{AOK}) \star \mathrm{E}$

25

$\begin{array}{ll}C O K & =C \\ L A B & =0\end{array}$

DO $35 \mathrm{~A}=1$, NARCS

$I A=I(A)$

$\mathrm{NA}(\mathbf{N})=0$
$\mathrm{NB}(\mathbf{N})=0$

IDETERMINE THE CANDIDATE ARC FOR THE TREE

$\&$

IF ( (NA(IA) . EQ. 0 . AND. NA(JA) .EQ. 0) .OR. (NA(IA) .NE. 0

. AND. NA(JA). NE, 0)) GO TO 35

$\dot{C}=\operatorname{CosT}(A)+P I(I A)-P I(J A)$

(FLOW (A) GE. LO(A) (FLOW(A).GE. HI(A) OR. OR.

$(F L O W(A) \cdot G E \cdot L O(A)$.AND $N(J A)=I(A)$

$N B(J A)=A$

ELSE IF (NA (IA) . EQ. 0 ) THEN

IF (FLOW (A). LE. LO (A). OR

(FLOW(A). LE. HI (A).AND. C.LT. 0)) GO TO 35

$I A=I(A)$

$N A(I A)=-J(A)$

$\mathrm{NB}(I A)=-A$

END IF

LAB $=$

IF (NA(SNK) . NE. O) GO TO 50

35 CONTINUE IF (LAB.NE, 0) GO TO 40

DEL $=$ INF

DO $45 \mathrm{~A}=1$, NARCS

$\&$

$\begin{aligned} & I A=I(A) \\ & J A\end{aligned}=J(A)$

IF ( $(N A(I A)$. EQ. 0 .AND. NA(JA) .EQ. 0$)$.OR. (NA(IA) .NE. 0

AND. NA(JA), NE. 0)) GO TO 45

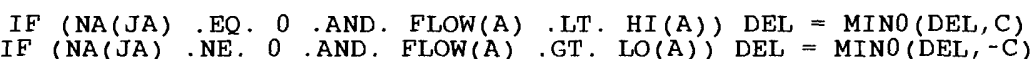

45 CONTINUE

$\mathrm{CCOK}=\mathrm{COK}$

IF (DEL .EQ. INF . AND. (FLOW(AOK) . EQ. HI (AOK) .OR. FLOW(AOK) .EQ. 
\& $\begin{gathered}\mathrm{LO}(\mathrm{AOK}))) \text { DEL }=\mathrm{ABS}(\mathrm{CCOK}) \\ \text { IF (DEL .EQ. INF) THEN }\end{gathered}$

END IF

DO $6 \stackrel{N}{N}=1$, NNODS

6 CONTINUE

GO TO 10

$\mathrm{EPS}=\mathrm{INF}$

$\mathrm{NI}=\mathrm{SRC}$

$\mathrm{N} J=\operatorname{IABS}(\mathrm{NA}(\mathrm{NI}))$

$\begin{array}{ll}60 & \mathrm{NJ}=\operatorname{IABS}(\mathrm{NA}(\mathrm{NI}) \\ \mathrm{A}=\operatorname{IABS}(\mathrm{NB}(\mathrm{NI})) \\ \mathrm{C}=\operatorname{COST}(\mathrm{A})+\mathrm{PI}\end{array}$

$C=\operatorname{cosT}(A)+P I(N I)-P I(N J)$

IF (NB (NI). GT. O) THEN

$\mathrm{IF}(\mathrm{NA}(\mathrm{N}) \cdot \mathrm{EQ} \cdot 0) \mathrm{PI}(\mathrm{N})=\mathrm{PI}(\mathrm{N})+\mathrm{DEL}$

DEBUG $=$. TRUE.

$\mathrm{KARC}=\mathrm{AOK} * \dot{\mathrm{E}}$

GO TO 99
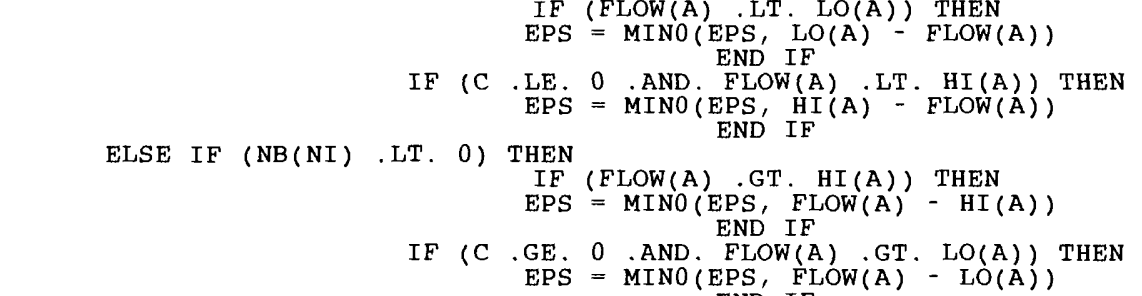

END IF

$\mathrm{NI}=\mathrm{NJ}$

IF (NI . NE. SRC) GO TO 60

$N J=\operatorname{IABS}(\mathrm{NA}(\mathrm{NI}))$

$A=\operatorname{IABS}(\mathrm{NB}(\mathrm{NI}))$

$\operatorname{FLOW}(A)=\operatorname{FLOW}(A)+\operatorname{ISIGN}($ EPS, NB(NI))

$\mathrm{NI}=\mathrm{N} \mathrm{J}$

$I F(N I . N E . S R C)$ GO TO 70

GO TO 10

99 CONTINUE

100 IF (.NOT. DEBUG) GO TO 90

90 RETURN

800 FORMAT ('SOLUTION INFEASIBLE') END

* Name:

$====x========$

* Purpose: Print the basic network information.

* Author: Xiaodong Jian

SUBROUTINE PRTINF (NDNAM, NDTYP, NDSEQ, NRES, TYPE, MXND,

$\&$
$\&$
$\&$
$\&$

MXARC, MXR,

II, JJ, HI , LO, COST, ARTYP, PTRE， REAR,

NNODS, PTDWAR, NDDWAR,

PERD, NARCS, C, XF, IOUT1)

$\begin{array}{ll}\text { IMPLICIT } & \text { NONE } \\ \text { INTEGER } & \text { MXARC, MXR, MXND }\end{array}$

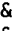

I I (MXARC), JJ (MXARC), HI (MXARC), LO (MXARC), COST (MXARC),

ARTYP (MXARC)， PTRE (MXR) , REAR (MXR)

PTDWAR (MXND, 2), NDDWAR (MXARC)

INTEGER NNODS, NARCS, IOUTI

$\begin{array}{ll}\text { REAL } & \text { C, XF, PERD, } X \\ \text { CHARACTER } & \text { NDNAM }(M X N D) *(*)\end{array}$

INTEGER NDTYP(MXND) NDSEO(MXND)

INTEGER NRES, TYPE， N， I，J， RES， LIM1， LIM2， L

INTEGER ND, OND

INTEGER ARC, ZONE

CHARACTER TYP*4

CHARACTER $* 10$ NCST, UCST, LCST, ONCST

$\mathrm{X}=\mathrm{PERD} * \mathrm{C} * \mathrm{XF}$

IF (TYPE , EQ. 0 .OR. TYPE .EQ. 1) THEN

WRITE THE NODE NAME AND TYPE

21

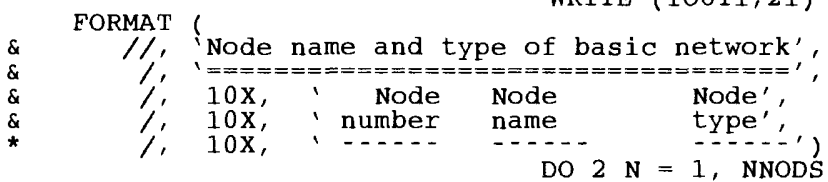

WRITE (IOUT1, 21)

FORMAT (10X, I7, 3X, A12, A)

EISE

WRITE (IOUT1, 23) N, NDNAM(N), 'GENERAL'

CONTINUE

END IF

IF (TYPE .EQ. 0 .OR. TYPE .EQ. 2) THEN

WRITE THE ARCS AND BOUNDS OF A NETWORK 


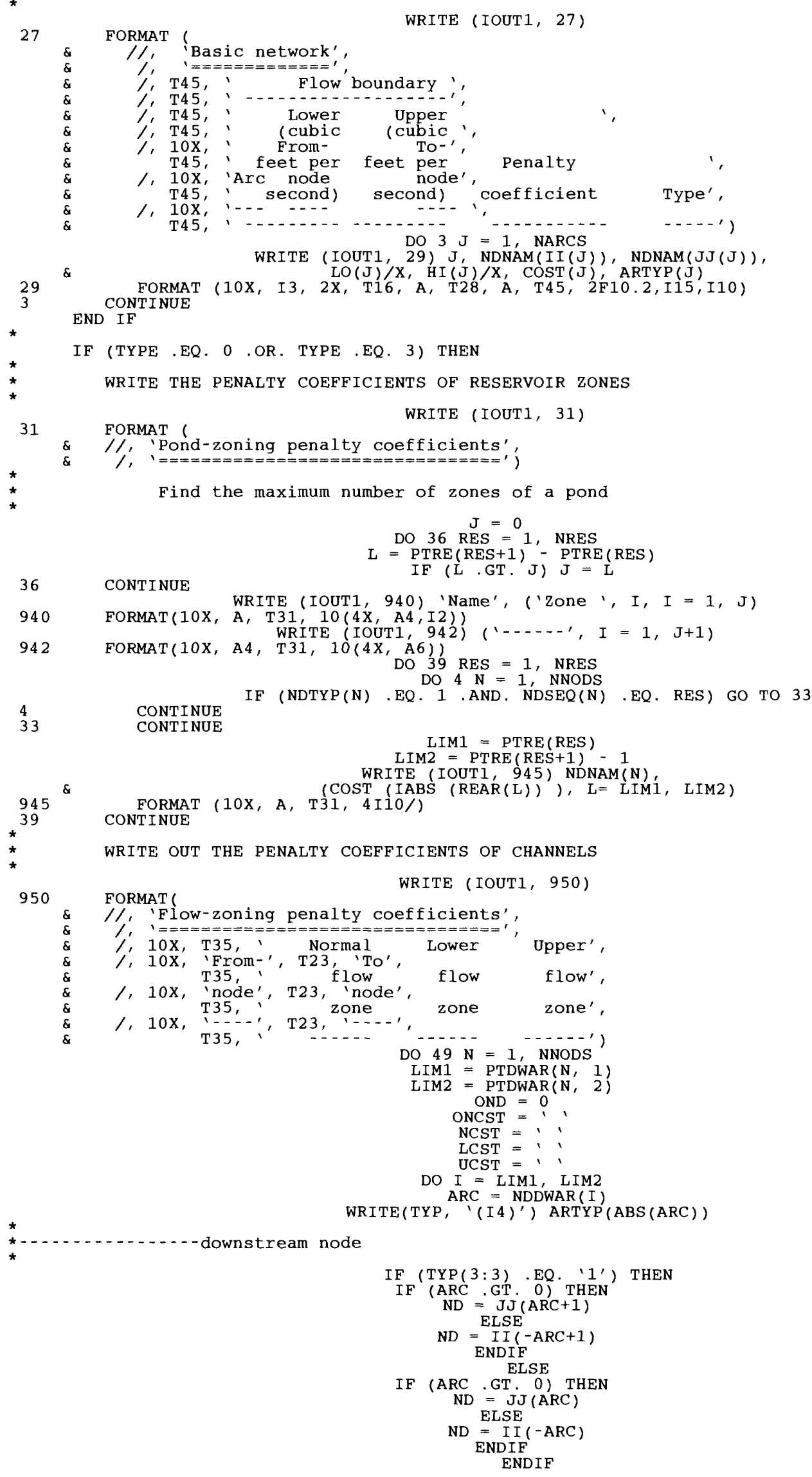




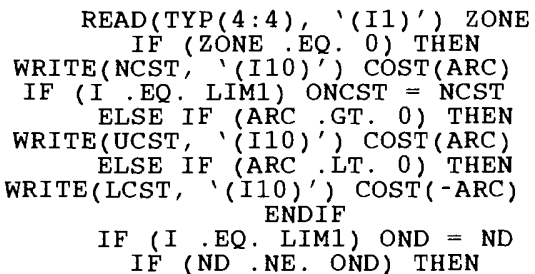

WRITE (IOUTI, 43 ) NDNAM(N), NHENAM(OND), ONC'ST, LCST, UCST

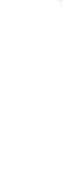

INTEGER FN，TN， K 


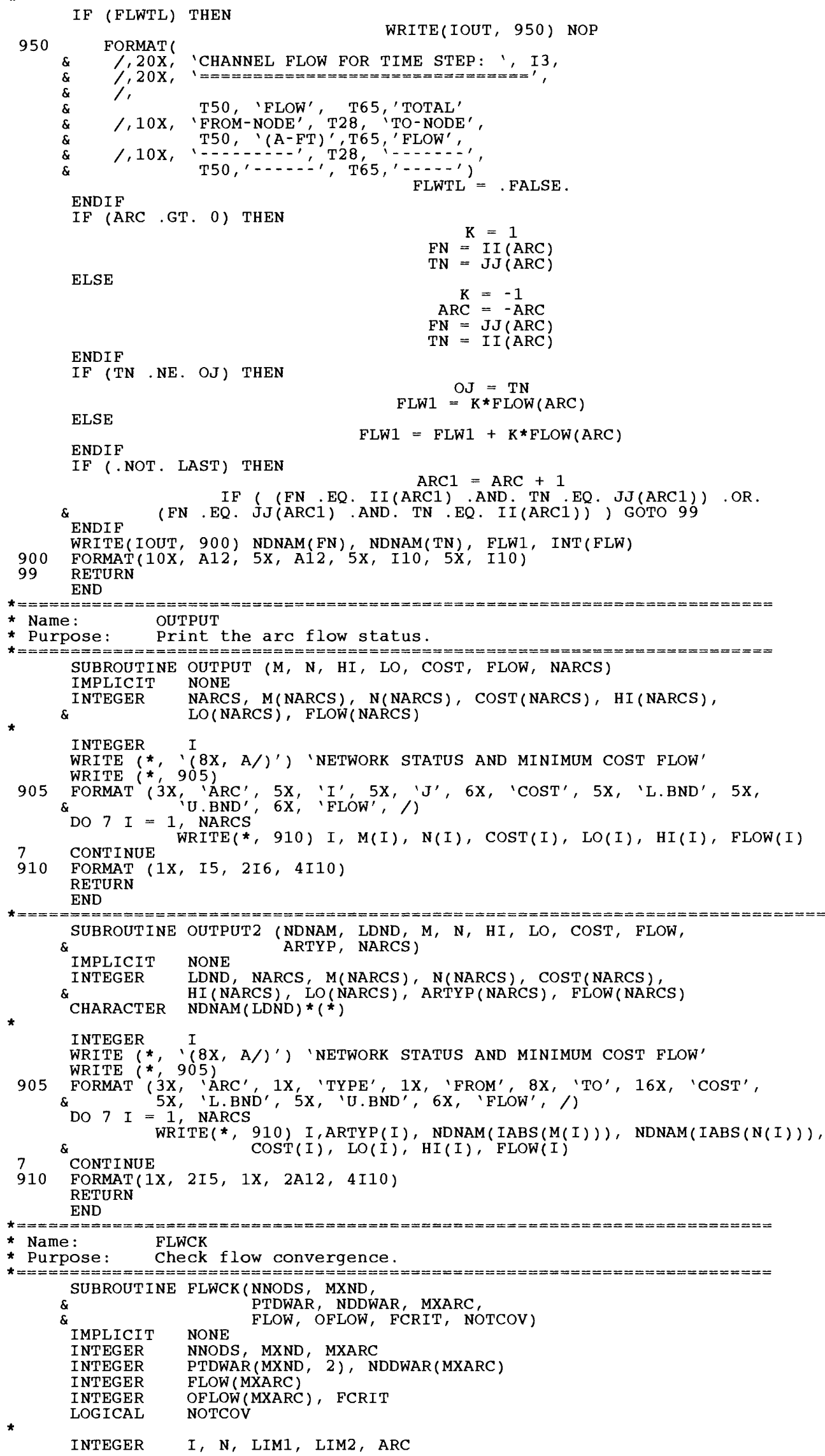


NOTCOV $=$. FALSE

DO $50 \mathrm{~N}=1$, NNODS

$$
\begin{aligned}
& \text { LIM1 }=\operatorname{PTDWAR}(\mathrm{N}, 1) \\
& \text { LIM2 }=\operatorname{PTDWAR}(\mathrm{N}, 2) \\
& \text { DO I }=\text { LIM1 LIM2 }
\end{aligned}
$$

IF (ABS (FLOW(ARC) - OFLOW(ARC)) . LT. FCRIT) THEN CONTINUE

ELSE
NOTCOV $=$. TRUE. ENDIF

OFLOW (ARC) $=$ FLOW (ARC)

\section{CONTINUE} ENDDO END

CALL NAMNUM(NND, NDNAM, $\operatorname{COLSTR}(I), N D, 0$, ERR) 


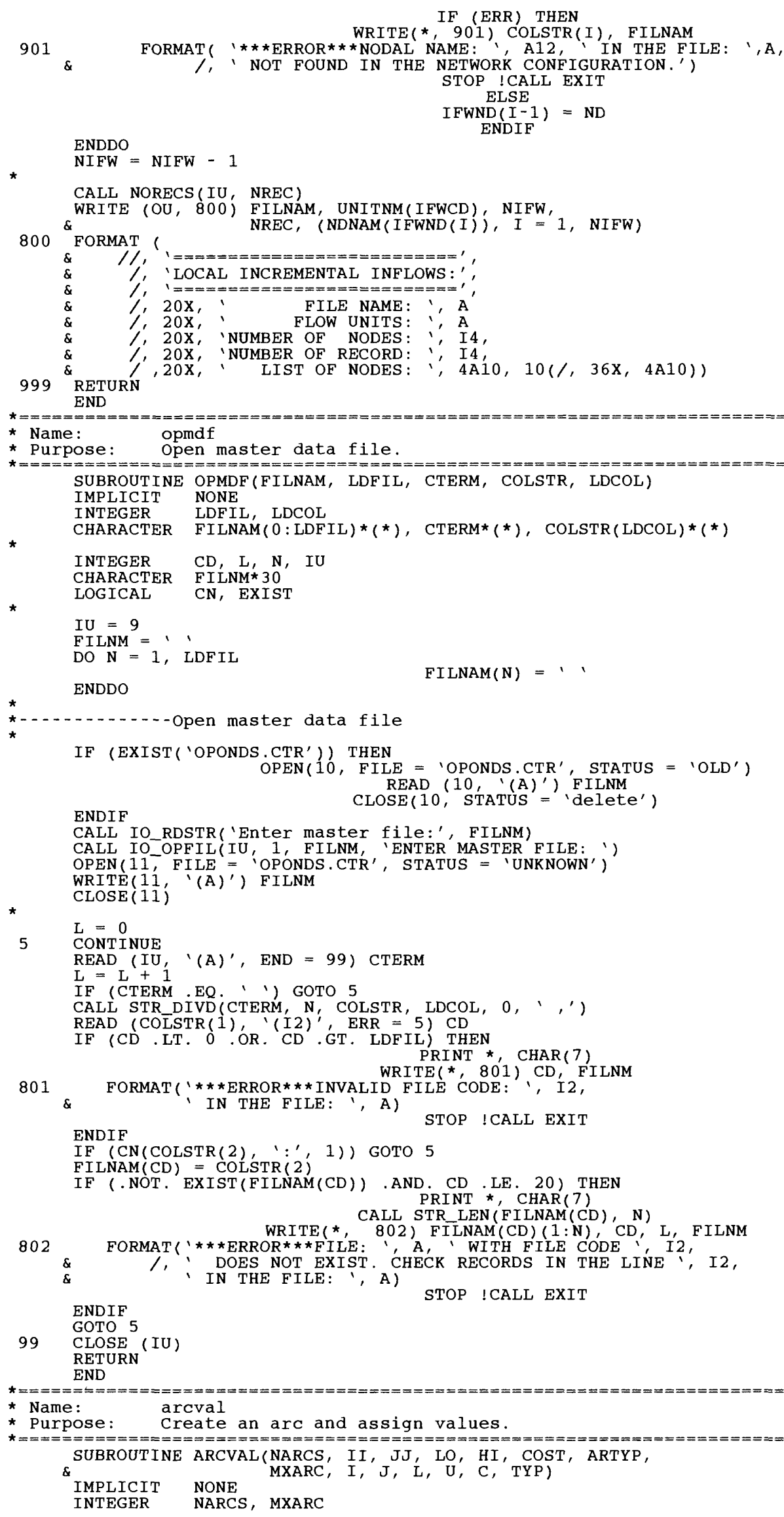


INTEGER II (MXARC), JJ(MXARC), LO(MXARC), HI(MXARC),

INTEGER $I$, J, L, U, C, TYP

NARCS $=$ NARCS +1

II (NARCS) $=$ I

$J J($ NARCS $)=J$

LO $($ NARCS $)=\mathrm{L}$

$H I(N A R C S)=U$

$\operatorname{COST}($ NARCS $)=\mathrm{C}$

ARTYP(NARCS) $=$ TYP

RETURN

END

$\star *=====$

* Purpose:

Month

TRANSFORM THE MONTH WITH NUMBER OR CHAR.

SUBROUTINE MONTH (TY, NUM, CHA)

IMPLICIT NONE

CHARACTER * 4 , MOTH(12), CHA

INTEGER TY, NUM, I

DATA MOTH / 'JAN.', 'FEB.', 'MAR.', 'APR.', 'MAY', 'JUN.',

IF (TY . EQ. 1) THEN

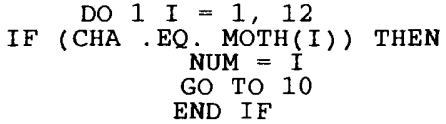

1 CONTINUE ELSE IF (TY , EQ . 2) THEN

ELSE

$\mathrm{CHA}=\mathrm{MOTH}(\mathrm{NUM})$

END IF

CONTINUE

RETURN

END

SUBROUTINE PNCK (PN, IU, FLAG, CTERM， COLSTR， LDCOL)

IMPLICIT NONE

$\begin{array}{ll}\text { INTEGER } & \text { PN, LDCOL， IU } \\ \text { LOGICAL } & \text { FLAG }\end{array}$

CHARACTER CTERM* (*)，COLSTR(LDCOL)* (*)

INTEGER N

LOGICAL

FLAG $=$. TRUE.

DO WHILE (CTERM . EQ. ' '

READ (IU, ' (A)', END = 999) CTERM

ENDDO

CALL STR DIVD(CTERM, N, COLSTR, LDCOL, 0, ', ' )
READ (COLSTR(2); '(I 2)', N
IF (CN COLSTR(1), 'PART', 1). AND. N . EO. PN) TH

IF (CN(COLSTR(1), '(PART', 1 ). AND. N . EQ. PN) THEN

ELSE FLAG $=$. FALSE

IF (CN(COLSTR(1), 'PART', 1).AND. N .GT. PN) THEN

BACKSPACE ( IU)

GOTO 999

ENDIF

PRINT * , CHAR ( 7$)$

801 FORMAT( $1 * * *$ ERROR $* * *$ ERROR IN WRITE $(*,, 801)$

\& 1 OF NETWORK DATA FILE')

CALL STR_LEN(CTERM, N)

PRINT *, 'RECORD = ' CTERM(1:N)

ENDIF

999 RETURN

END

LOGICAL FUNCTION CNINT(ISEED, NOIX, IX, LOC)

IMPLICIT NONE

INTEGER ISEED， NOIX， IX(NOIX)， LOC

INTEGER I

CNINT $=$.FALSE

DO I $=1$, NOIX

IF (ISEED . EQ. IX(I )) THEN

CNINT $=$ TRUE

$\mathrm{LOC}=\mathrm{I}$

GOTO 99

ENDDO

ENDIF

99 RETURN

END

LOGICAL FUNCTION CN2INT(ISD1, ISD2, NOIX, IX1, IX2, LOC)

IMPLICIT NONE

INTEGER ISD1, ISD2, NOIX, IX1(NOIX)，IX2(NOIX)，LOC 


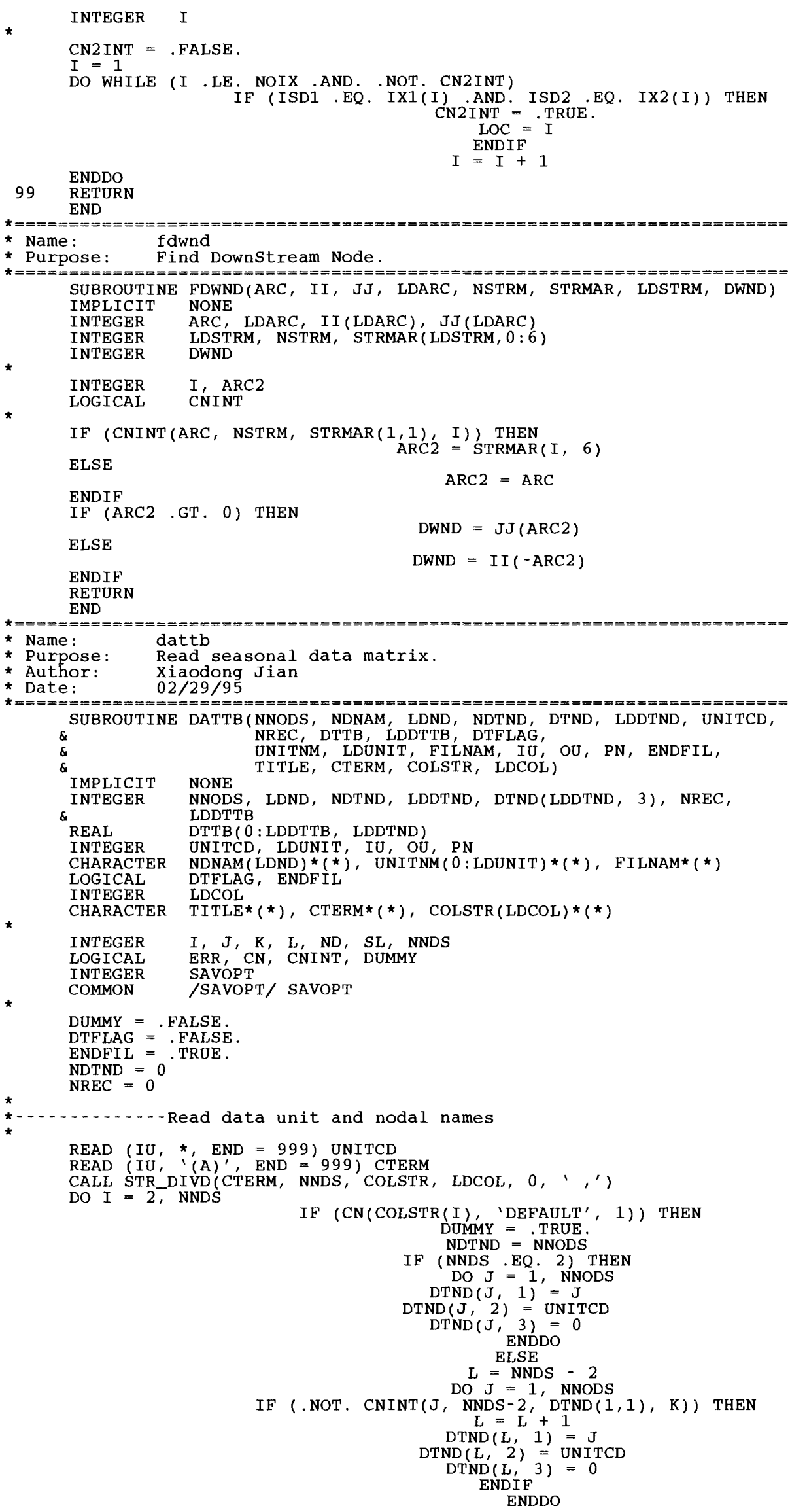




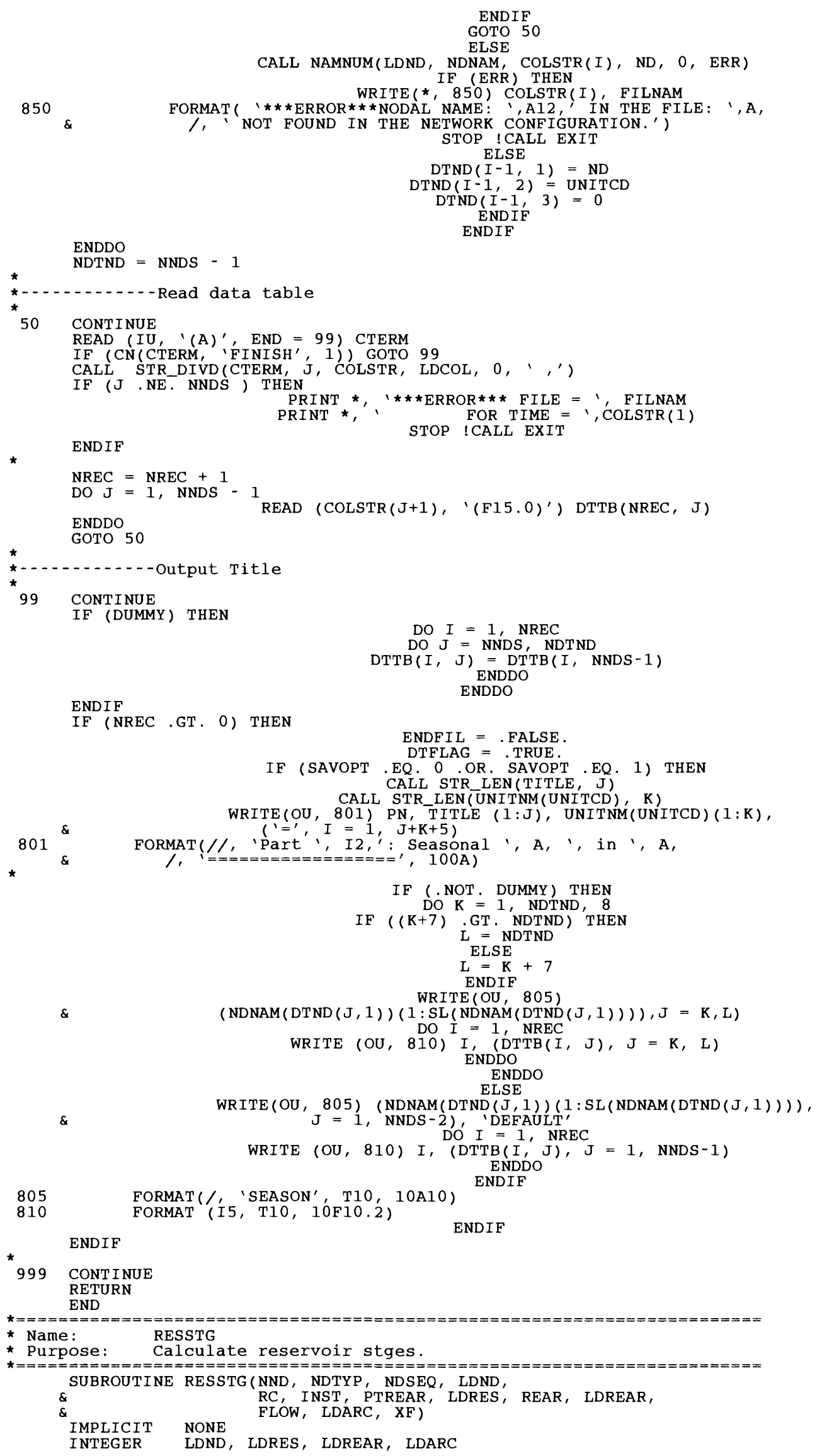




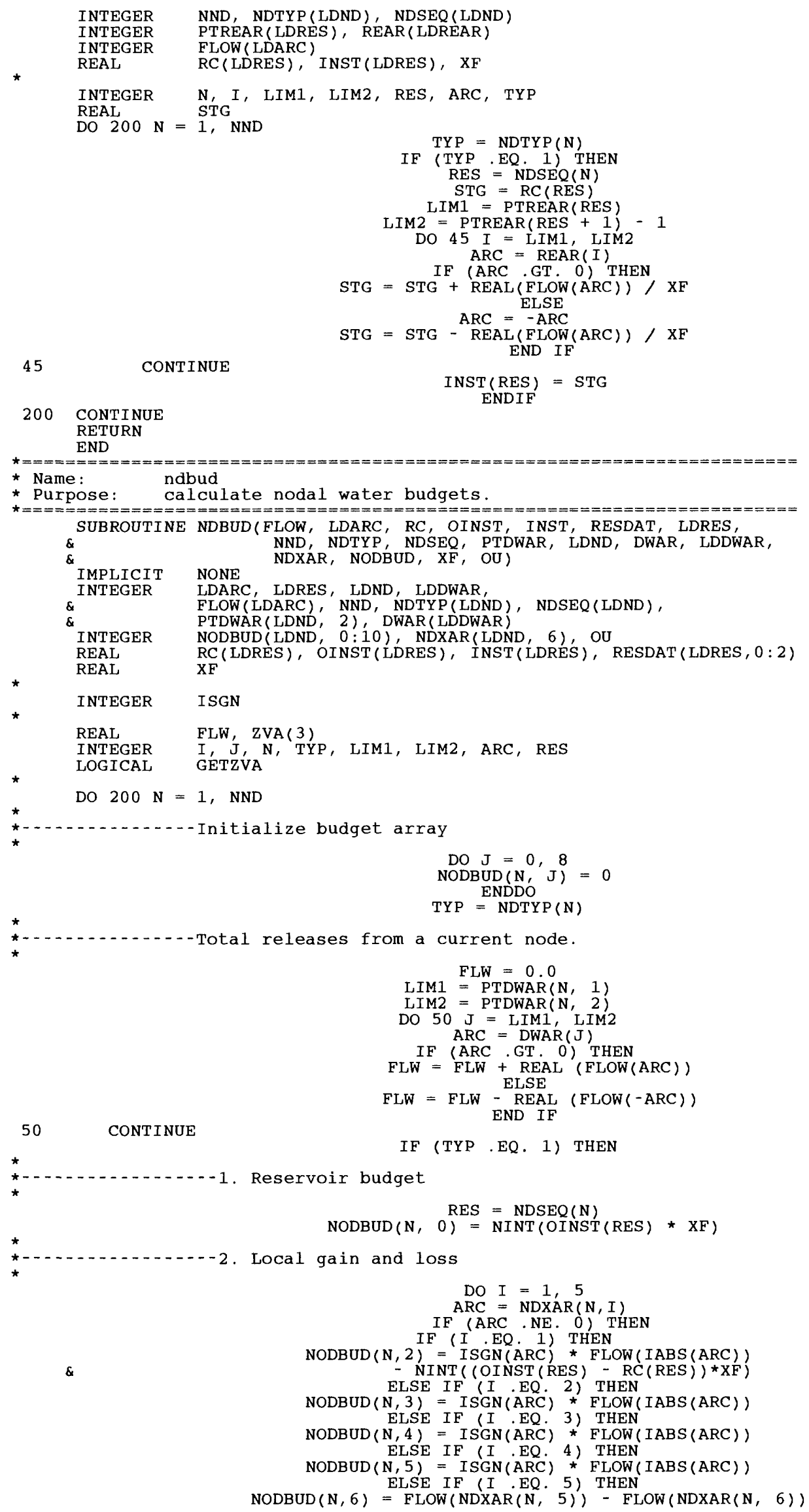




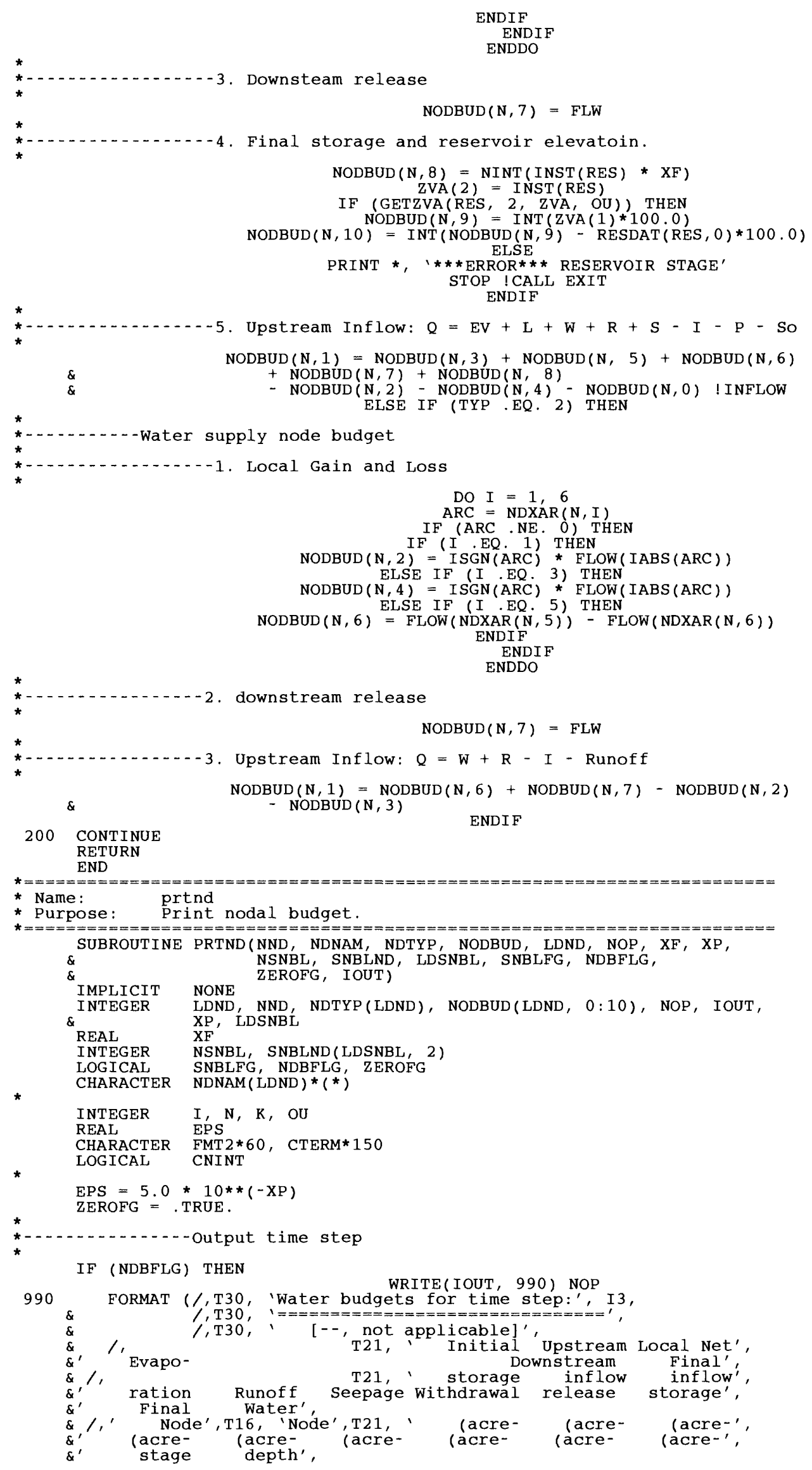




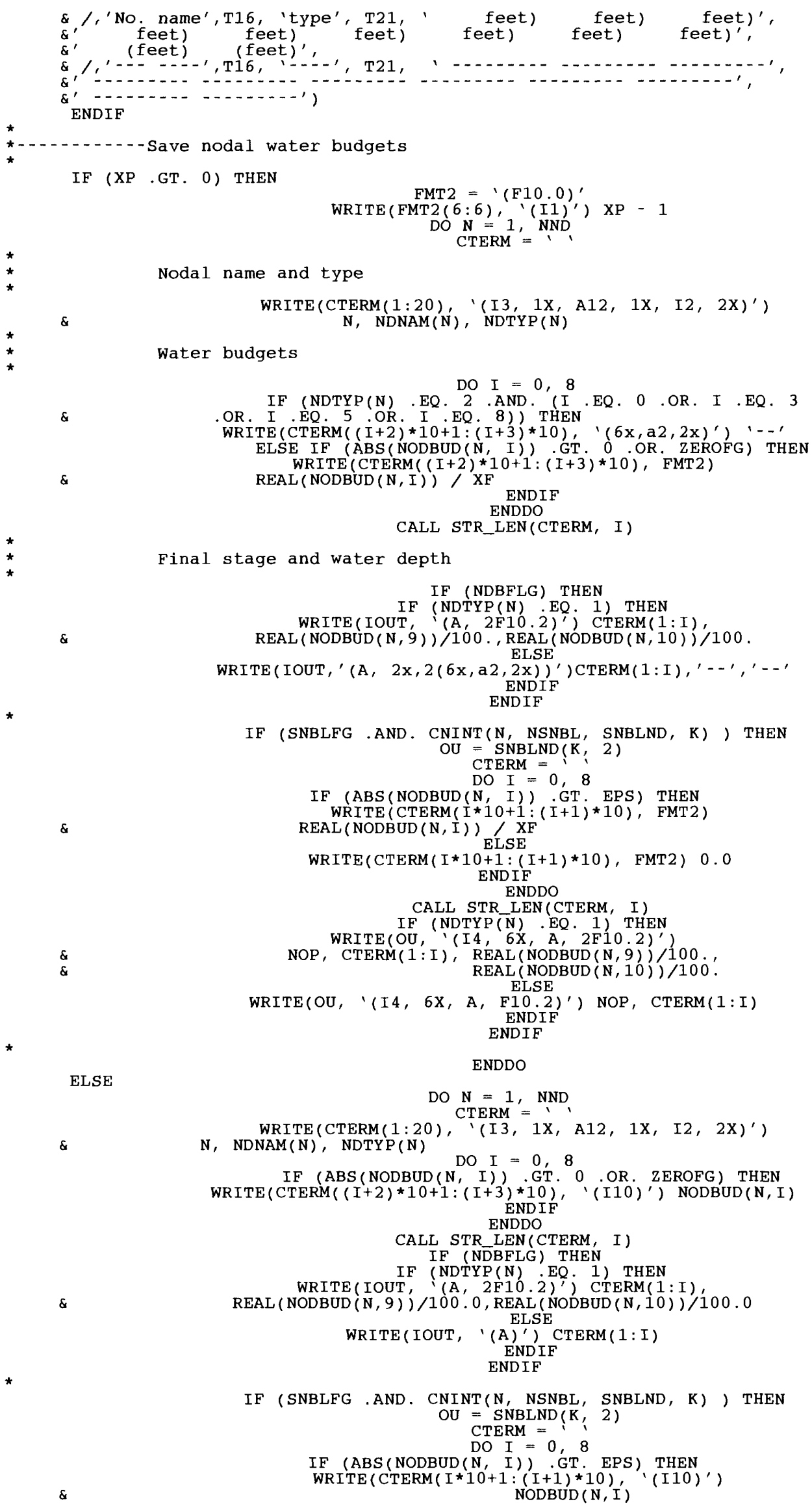

ENDDO 


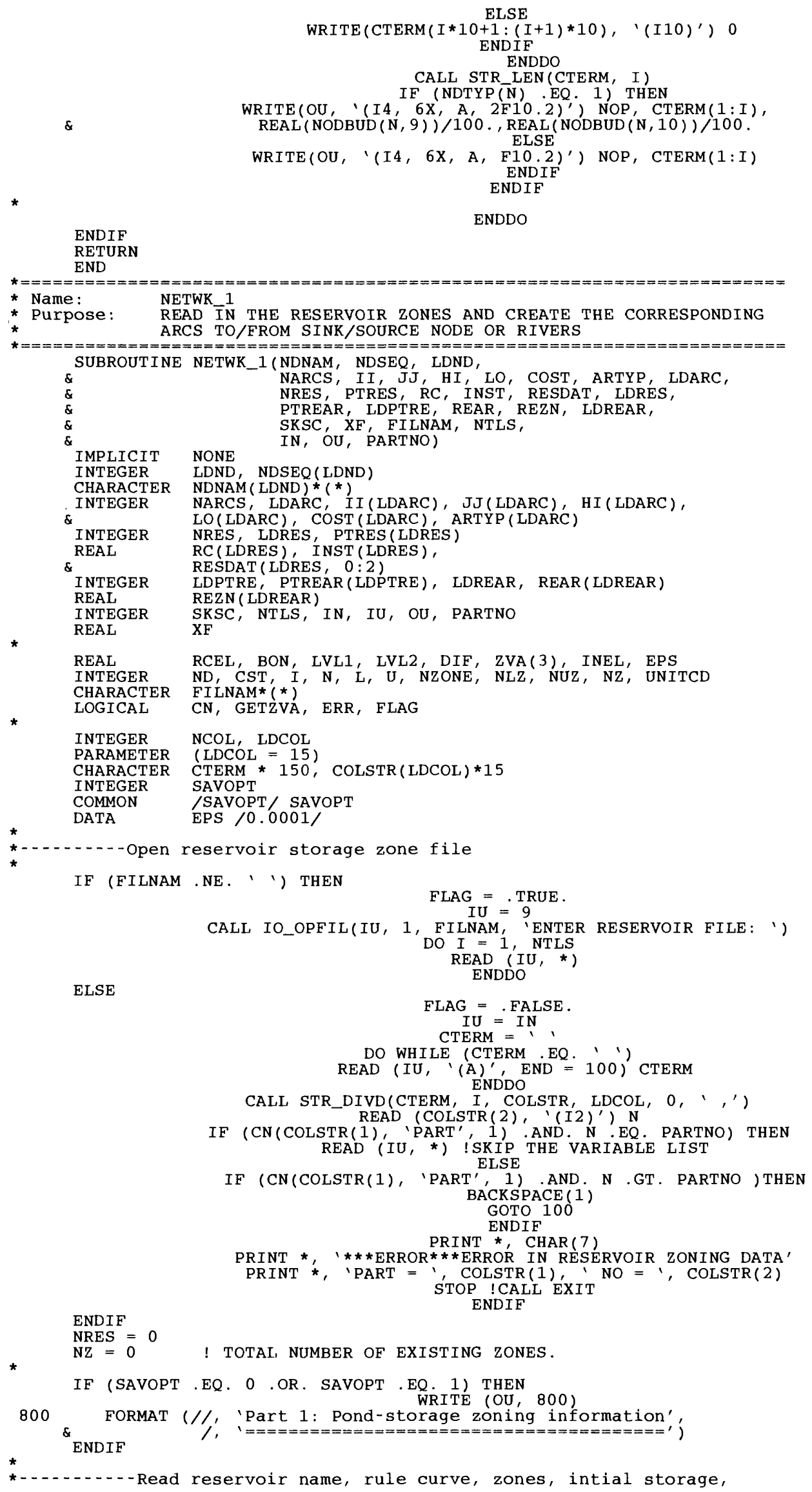




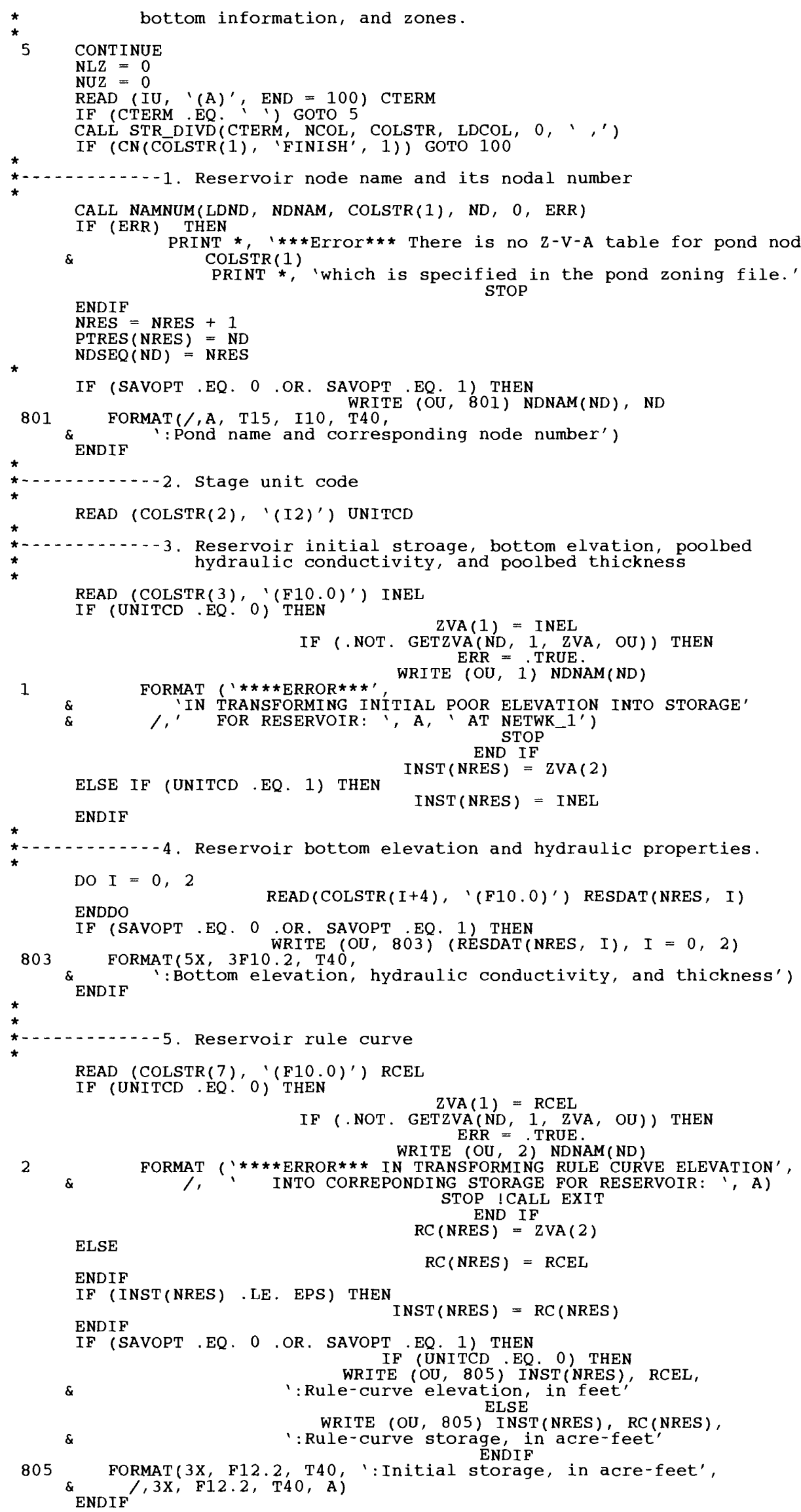


LVL1 $=$ RC (NRES)

LVL2 $=$ RC (NRES)

NZONE $=($ NCOL -7$) / 2$

IF (NZONE. EQ. O) THEN

$\&$ PRINT *, $* \star \star$ ERROR $* \star *$ RESERVOIR STORAGE ZONE IS NOT DEFINED', 'FOR NODE: ', NDNAM(ND)

ENDIF STOP ! CALL EXIT

DO $25 \mathrm{~N}=1, \mathrm{NZONE}$

$$
\begin{gathered}
\mathrm{NZ}=\mathrm{NZ}+1 \\
\operatorname{READ}\left(\operatorname{COLSTR}\left(N^{*} 2+6\right),(\mathrm{F} 10.0)^{\prime}\right) \\
\operatorname{READ}\left(\operatorname{COLSTR}\left(\mathrm{N}^{*} 2+7\right),(\mathrm{ION}\right.
\end{gathered}
$$

TRANSFORM THE BOND FROM STAGE TO A VOLUME ENDIF

$$
\operatorname{ZVA}(1)=\text { BON }
$$
ENDIF

FORMAT (I5, F10.2, I7, T40, A) ENDIF

$$
\begin{gathered}
\text { DIF }=\text { BON }- \text { RC (NRES) } \\
\text { IF (DIF . GE. 0) THEN } \\
\text { NUZ = NUZ }+1 \\
U=\text { NINT ((BON }- \text { LVL } 1) * X F) \\
\text { LVL1 }=\text { BON }
\end{gathered}
$$

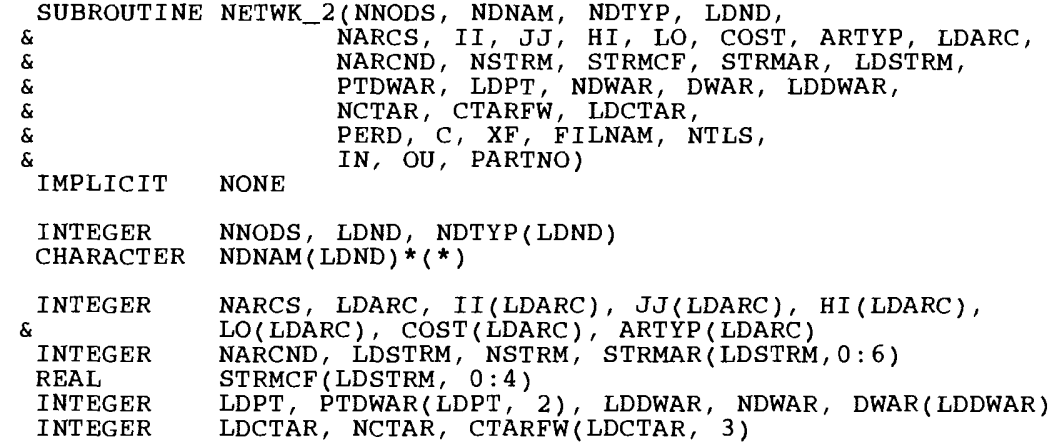




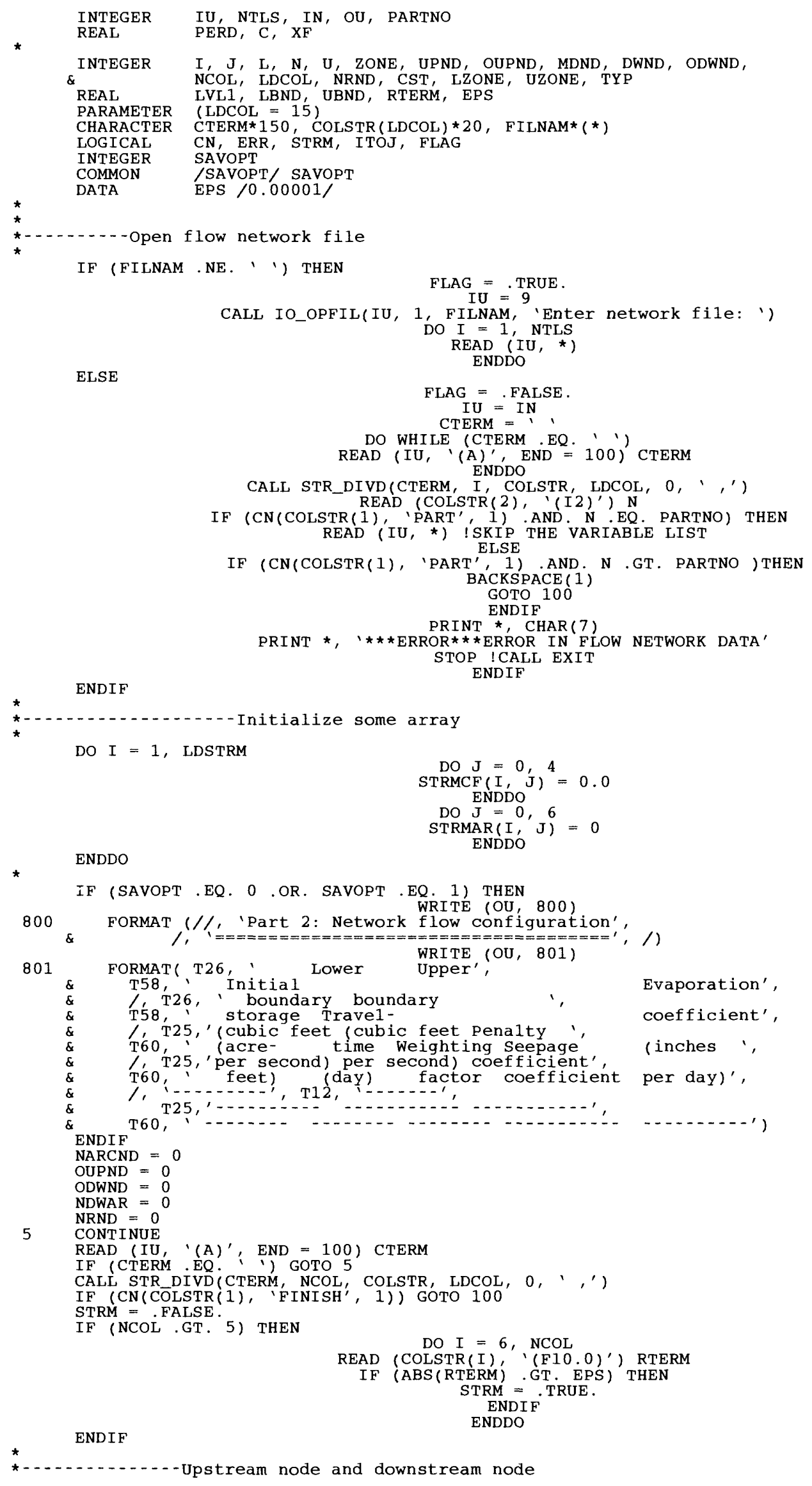


CALL NAMNUM(LDND， NDNAM, $\operatorname{COLSTR}(1), \operatorname{UPND}, 0$, ERR) IF (ERR) THEN

NNODS $=$ NNODS +1

$\operatorname{NDNAM}$ (NNODS) $=\operatorname{COLSTR}(1)$

CALL STR_CORS (NDNAM(NNODS), 1)

$$
\text { NDTYP (NNODS) }=
$$

ENDIF

UPND $=$ NNODS

CALL NAMNUM(LDND, NDNAM, $\operatorname{COLSTR}(2), \operatorname{DWND}, 0, \mathrm{ERR}$ )

IF (ERR) THEN

NNODS $=$ NNODS +1

$\operatorname{NDNAM}(\operatorname{NNODS})=\operatorname{COLSTR}(2)$

CALL STR CORS (NDNAM (NNODS), 1)

NDTYP (NNODS) $=2$

ENDIF

DWND $=$ NNODS

IF (UPND .NE. OUPND) THEN

NRND $=$ NRND +1

PTDWAR (UPND, 1) $=$ NDWAR +1

OUPND $=$ UPND

ENDIF

ODWND $=0$

IF （DWND . NE. ODWND） THEN

$$
\begin{aligned}
\text { ZONE } & =1 \\
\text { UZONE } & =0 \\
\text { LZONE } & =0 \\
\text { ODWND }= & \text { DWND }
\end{aligned}
$$

ELSE

ENDIF

$$
\mathrm{ZONE}=\mathrm{ZONE}+1
$$

作

READ (COLSTR (3), '(F10.0)') LBND

READ (COLSTR (4), ( $(F 10.0)^{\prime}$ ') UBND

READ (COLSTR(5)', '(I10)') CST

IF (ZONE . EQ. 1) THEN

$$
\begin{aligned}
& \text { ITOJ }=. \text { TRUE } \\
& \text { LVL1 = UBND } \\
& \text { IF (LBND .GE. 0) THEN } \\
& \mathrm{L}=\mathrm{NINT}(\mathrm{LBND} * \mathrm{C} \text { * PERD * XF) } \\
& \text { ELSE } \\
& \mathrm{L}=0 \\
& \mathrm{U}=\mathrm{NINT}(\mathrm{UBND} \text { * } \mathrm{C} \text { * PERD * XF) } \\
& \text { IF (STRM) THEN } \\
& \text { NARCND }=\text { NARCND + } 1 \\
& \text { MDND = LDND - NARCND } \\
& \operatorname{NDNAM}(M D N D)=\text { 'STRM' }
\end{aligned}
$$

WRITE(NDNAM(MDND) $\left.(5: 10), '(I 3.3,13.3)^{\prime}\right)$ UPND, DWND

ELSE

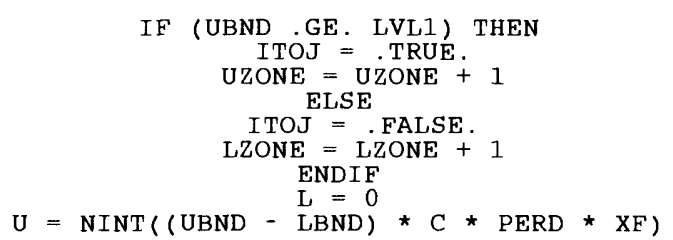

IF (ITOJ) THEN

$\&$

$\&$

ELSE
IF (STRM) THEN

TYP $=110+$ UZONE

STRMAR (NSTRM, 0 ) $=$ MDND

CALL ARCVAL(NARCS, II, JJ, LO, HI, COST, ARTYP, LDARC, UPND, MDND, L, U, CST, TYP)

NDWAR $=$ NDWAR +1

DWAR (NDWAR) $=$ NARCS

PTDWAR (UPND, 2) = NDWAR

STRMAR (NSTRM, 1) = NARCS

CALL ARCVAL (NARCS, II, JJ, LO, HI, COST, ARTYP,

LDARC, MDND, DWND, L, U, CST, TYP)

STRMAR(NSTRM, 6 ) $=$ NARCS

$$
\text { DO } I=6, \text { NCOL }
$$

$\operatorname{READ}\left(\operatorname{COLSTR}(I), '(F 15.0)^{\prime}\right)$ STRMCF (NSTRM，J)

$$
\text { ENDDO }
$$

TYP $=100+$ UZONE

CALL ARCVAL (NARCS, II, JJ, LO, HI, COST, ARTYP,

LDARC, UPND, DWND, L, U, 'CST, TYP')

NDWAR $=$ NDWAR +1

DWAR (NDWAR) $=$ NARCS

$\operatorname{PTDWAR}($ UPND, 2 ) = NDWAR

$$
\text { ENDIF }
$$




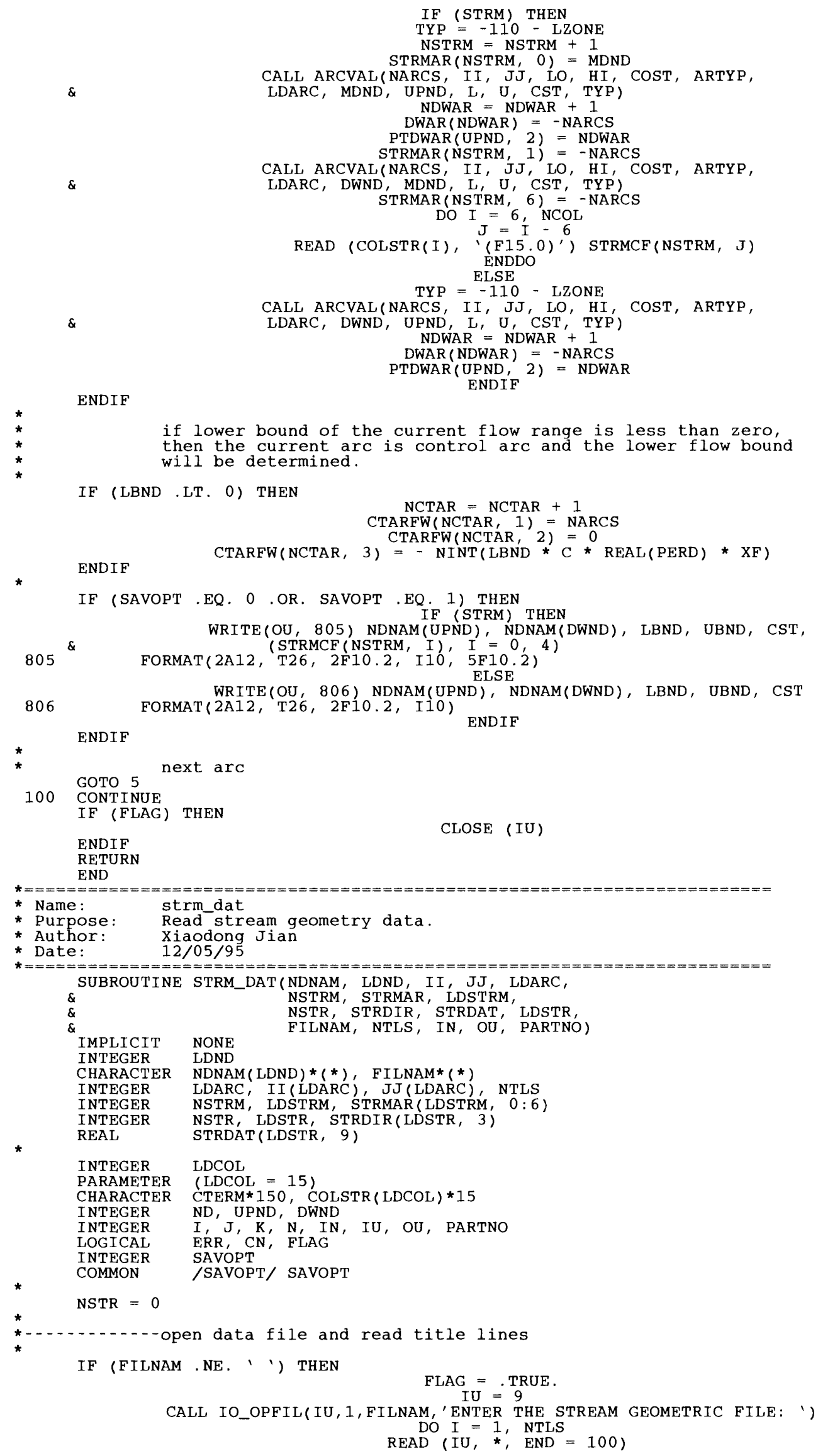


ELSE

ENDDO

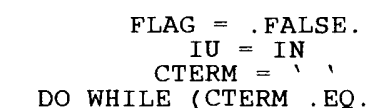

READ (IU, '(A)', END $=999)^{\prime}$ ' CTERM

CALL STR_DIVD(CTERM, I, COLSTR, LDCOL, 0，' ,')

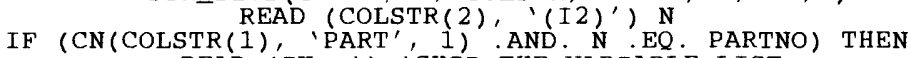

READ (IU, *) !'SKIP THE VARIABLE LIST

IF (CN $\left(\operatorname{COLSTR}(1), \operatorname{lPART}^{\prime}, 1\right)$. AND. $\mathbf{N}$. GT. PARTNO ) THEN

$\operatorname{BACKSPACE}(1)$

GOTO 100

ENDIF

PRINT *, $\operatorname{CHAR}(7)$

PRINT *, $* * *$ ERROR $* \star \star$ ERROR IN STREAM DATA

STOP ! CALL EXIT

ENDIF

$$
\text { ENDIF }
$$

IF (SAVOPT . EQ. 0 .OR. SAVOPT . EQ. 1) THEN

WRITE(OU, 800)

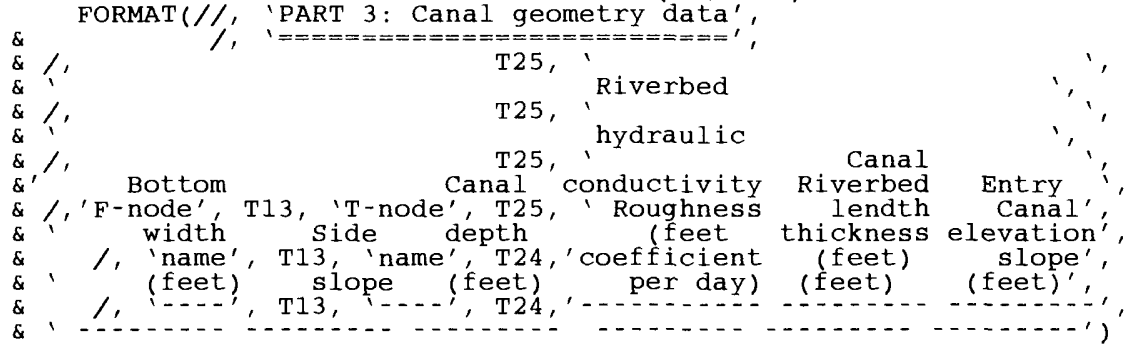

ENDIF

(-..-Read data

CONTINUE

READ ( IU, ' $(A)$ ', END = 100) CTERM

IF (CTERM . EO.' ') GOTO 5

CALL STR DIVD (CTERM, K COLSTR, LDCOL, $0,1, ')$

IF (CN(COLSTR(1), 'FINISH', 1)) GOTO 100

IF (K.LT. 7) THEN

PRINT *, $\operatorname{CHAR}(7)$

ENDIF

INCOMPLETE DATA SET IN GEOMETRIC FILE'

$=$ NSTR +1

DO $\mathrm{J}=1, \mathrm{~K}$ STOP ICALL EXTT

ENDDO

$\operatorname{IF}(J \underset{\text { CALL NAMNUM(LDND, }}{\operatorname{LE} .} 2) \operatorname{THEN}$
$\operatorname{THNAM}, \operatorname{COLSTR}(J), N D, 0$, ERR) STRDIR(NSTR, J) $=$ ND

$\operatorname{READ}\left(\operatorname{COLSTR}(J), \underset{\operatorname{ENDIF}}{(\operatorname{ELSE})^{\prime}}\right) \operatorname{STRDAT}(\operatorname{NSTR}, J-2)$

IF (SAVOPT . EQ. 0 .OR. SAVOPT . EQ. 1) THEN

WRITE (OU, 805) (NDNAM(STRDIR(NSTR, J)), J=1,2),

$\& \quad$ (STRDAT (NSTR, J), $J=1,9$ )

FORMAT (A12, A12, F10.4, F10.2, F10.6, F10.2, F10.6, 4F10.2)

ENDIF

100 CONTINUE

IF (FLAG) CLOSE(IU)

Find the middle stream node between the upstream node and downstream node.

DO $20 \mathrm{I}=1$, NSTR

$$
\text { DO } J=1 \text {, NSTRM }
$$

UPND $=\operatorname{II}(\operatorname{IABS}(\operatorname{STRMAR}(J, 1)))$

IF (UPND . EQ. STRDIR(I, J ( IABS (STRMAR $(J, 6)$ )

$\operatorname{STRDIR}(I, 3)=\operatorname{STRMAR}(\mathrm{J}, 0)$

GOTO 20

ENDIF

ENDDO

20 CONTINUE

$\operatorname{STRDIR}(I, 3)=0$

999 RETURN

END

* Name:

* Purpose:

strm_rout

Channel Routing.

SUBROUTINE STRM_ROUT (

\&

NARCS, II, JJ, HI, LO, COST, FLOW, ARTYP, MXARC, 


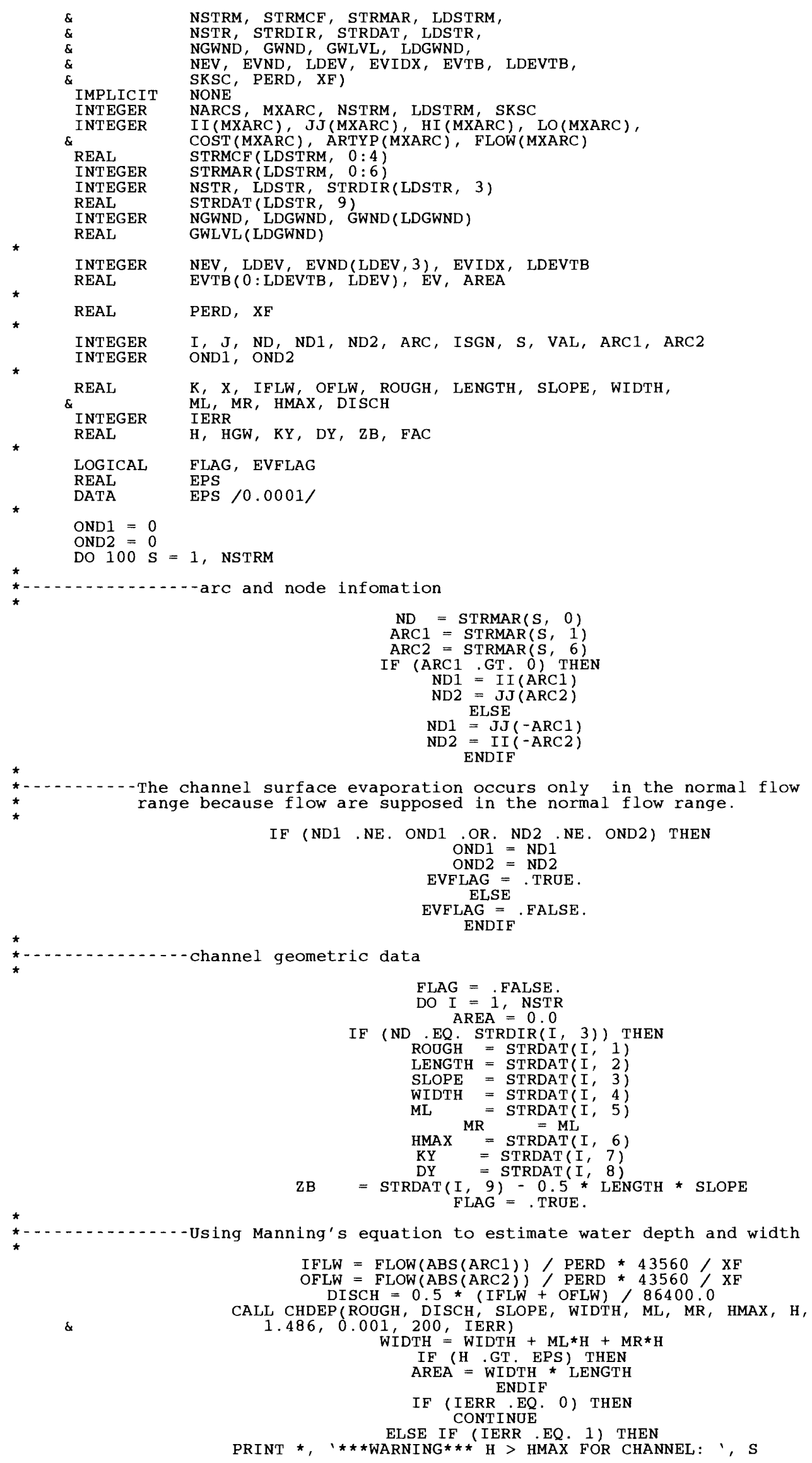




$$
\begin{aligned}
& \text { IF (STRMCE (S, } 3 \text { ) . GT. EPS) THEN } \\
& \text { ARC }=\text { STRMAR (S, } 1) \\
& \text { VAL }=\operatorname{NINT}(\operatorname{ISGN}(\operatorname{ARC}) \star \operatorname{STRMCF}(S, 3) \star \operatorname{FLOW}(\operatorname{IABS}(\operatorname{ARC})))
\end{aligned}
$$

* - Estimate Groundwater level if available

*

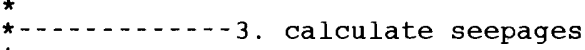

IF (NGWND.GT. O) THEN

HGW $=0.0$

$\mathrm{J}=0$

IF (ND1 EQ. GWND(I) .OR. ND2 . EQ. GWND(I)) THEN

$J=J+1$

HGW + GWLVL(I)

NDIF

IF ( J . GT . O) THEN

$\mathrm{HGW}=\mathrm{HGW} / \mathrm{REAL}(\mathrm{J})$

ENDIF

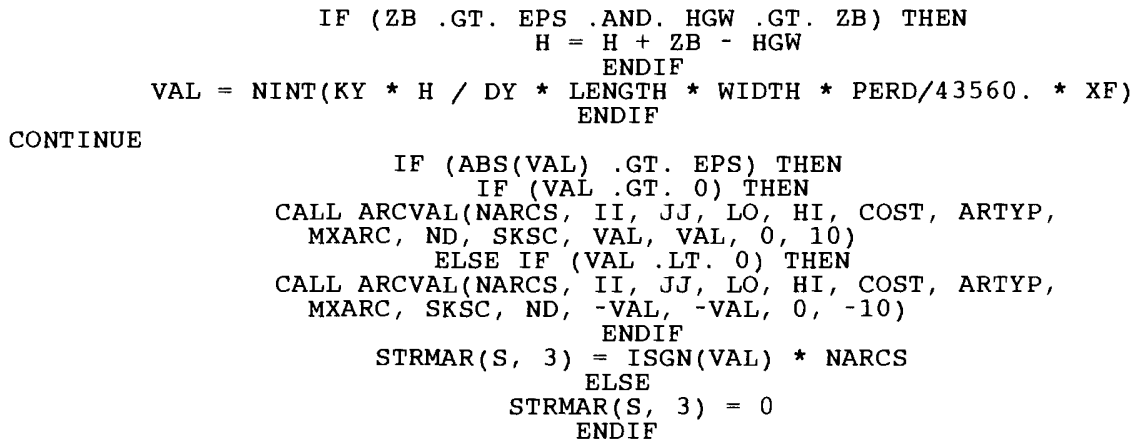

B. Channel water surface evaporation. Surface evaporation coeffiecints are obtained in two ways: (1) If the channel water surface evaporation coefficient is specified, this value will be used

for whole simulation period, and (2) If the ev value is not specified the values in the upstream and downstream nodes will be averaged.

IF (ABS (STRMCF (S, 4)) .GT. EPS .AND. EVFLAG . AND.

AREA . GT . EPS) THEN

$$
\begin{gathered}
\text { EV }=0.0 \\
\text { IF (STRMCF }(S, 4) . \mathrm{GT} .0) \text { THEN } \\
\text { EV }=\text { STRMCE(S, 4) } \\
\text { ELSE IF (NEV .GT. O) THEN } \\
\text { J }=0
\end{gathered}
$$

IF (ND1.EQ. $\operatorname{EVND}(I, 1)$. OR. ND2 $. \mathrm{EQ} . \operatorname{EVND}(I, 1))$ THEN

F (EVND $(I, 2) J+1$

F $(\operatorname{EVND}(I, 2), \mathrm{EQ} .0)$ THEN

ELSE IF (EVND $(I, 2)$. EQ, 2) THEN

$$
\mathrm{FAC}=12.0
$$$$
\mathrm{FAC}=1.0
$$

$\mathrm{IF}(\operatorname{EVND}(\mathrm{I}, 3) . \mathrm{NE} .0)$ THEN
$\mathrm{EV}=\mathrm{EV}+\operatorname{EVTB}(0, \mathrm{I})$ * FAC

$$
\mathrm{EV}=\mathrm{EV}+\operatorname{EVTB}(\operatorname{EVIDX}, \mathrm{I}) * \mathrm{FAC}
$$

ENDIF

ENDIF
ENDDO

$$
\text { IF (J } \underset{\text { EV }}{\text { EVT } ; ~} \mathrm{~J}) \text { THEN }
$$

IF (EV GT EPS) THEN

$\mathrm{VAL}=\operatorname{NINT}(\mathrm{EV} * \mathrm{PERD} / \mathrm{i} 2.0 *$ AREA $/ 43560.0 * \mathrm{XF})$

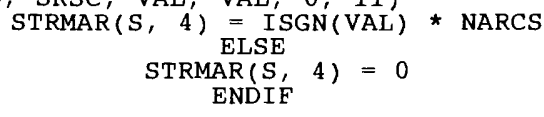


$\&$ CALL ARCVAL(NARCS, I I, JJ, LO, HI, COST, ARTYP,

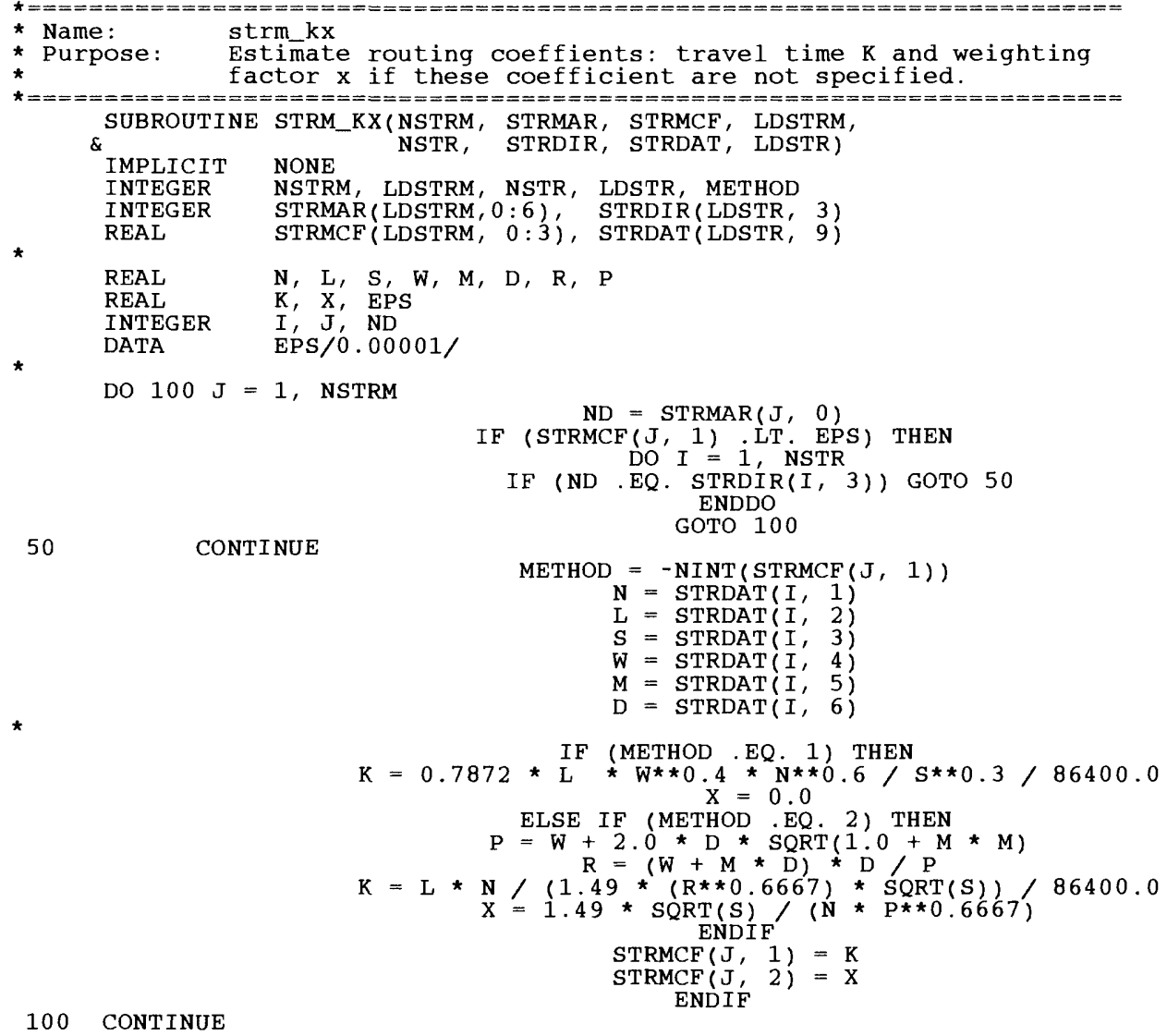


END

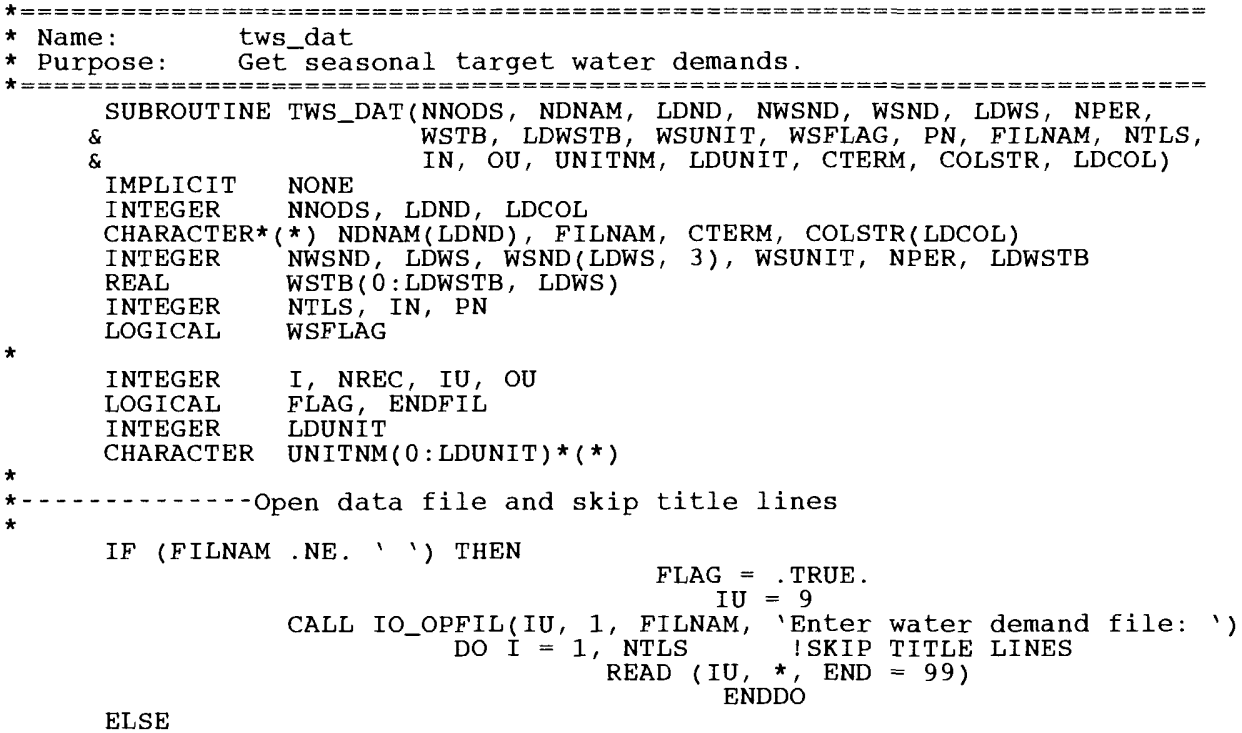

ELSE ENDDÓ

$$
\begin{gathered}
\text { FLAG }=. \text { FALSE } . \\
\text { IU }=\text { IN }
\end{gathered}
$$

CALL PNCK(PN, IU, ENDFIL, CTERM, COLSTR, LDCOL)

*......-. Read units, nonal names, and data from a file and

print these information into general output file.

CALL DATTB (NNODS, NDNAM, LDND, NWSND, WSND, LDWS, WSUNIT,

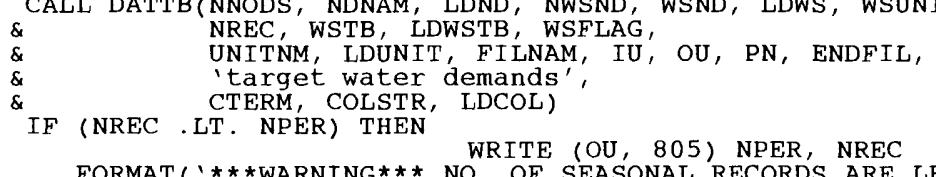

805

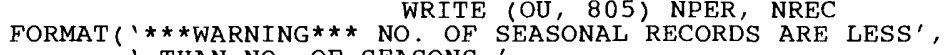

THAN NO. OF SEASONS.'

$\begin{array}{ll}\& & \text { NH. OF RECORDS: ;, I3, } \\ \& & \text { NO. OF SEASONS : I3) }\end{array}$

ENDIF

* 99 CONTINUE

IF (FLAG) CLOSE (IU)

RETURN

END

* Purpose: Rea d current target water demand and create

* corresponding TWS arcs.

SUBROUTINE TWS ARC(NARC, II, JJ, LO, HI, COST, ARTYP, LDARC

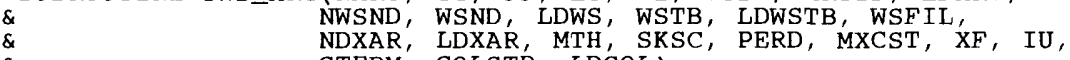

'IMPLICIT NONE CTERM, COLSTR, LDCOL)

INTEGER NARC, LDARC,

$\&$

I (LDARC)，JJ (LDARC)，LO (LDARC), HI (LDARC),

COST (LDARC), ARTYP (LDARC)

INTEGER NWSND, LDWS, WSND(LDWS, 3)， LDWSTB

REAL

LOGICAL

WSTB ( 0 : LDWSTB, LDWS)

WSFIL

LDXAR，NDXAR(LDXAR， 6)

INTEGER IU, MTH， SKSC， MXCST

REAL

PERD, XF

INTEGER LDCOL

CHARACTER CTERM*(*), COLSTR(LDCOL)*(*)

INTEGER I， J, N，ND， NNDS, NV

$\begin{array}{ll}\text { REAL } & \text { UC }(0: 2) \\ \text { LOGICAL } & \text { TDFLAG }\end{array}$

*-.-.---Data unit conversion factor (ac-ft)

$\mathrm{UC}(0)=1 \cdot 0$

$\mathrm{UC}(1)=\mathrm{PERD} * 86400.0 / 43560.0$

$\mathrm{UC}(2)=\mathrm{PERD} / 43560.0$

*

TDFLAG $=$. FALSE. 


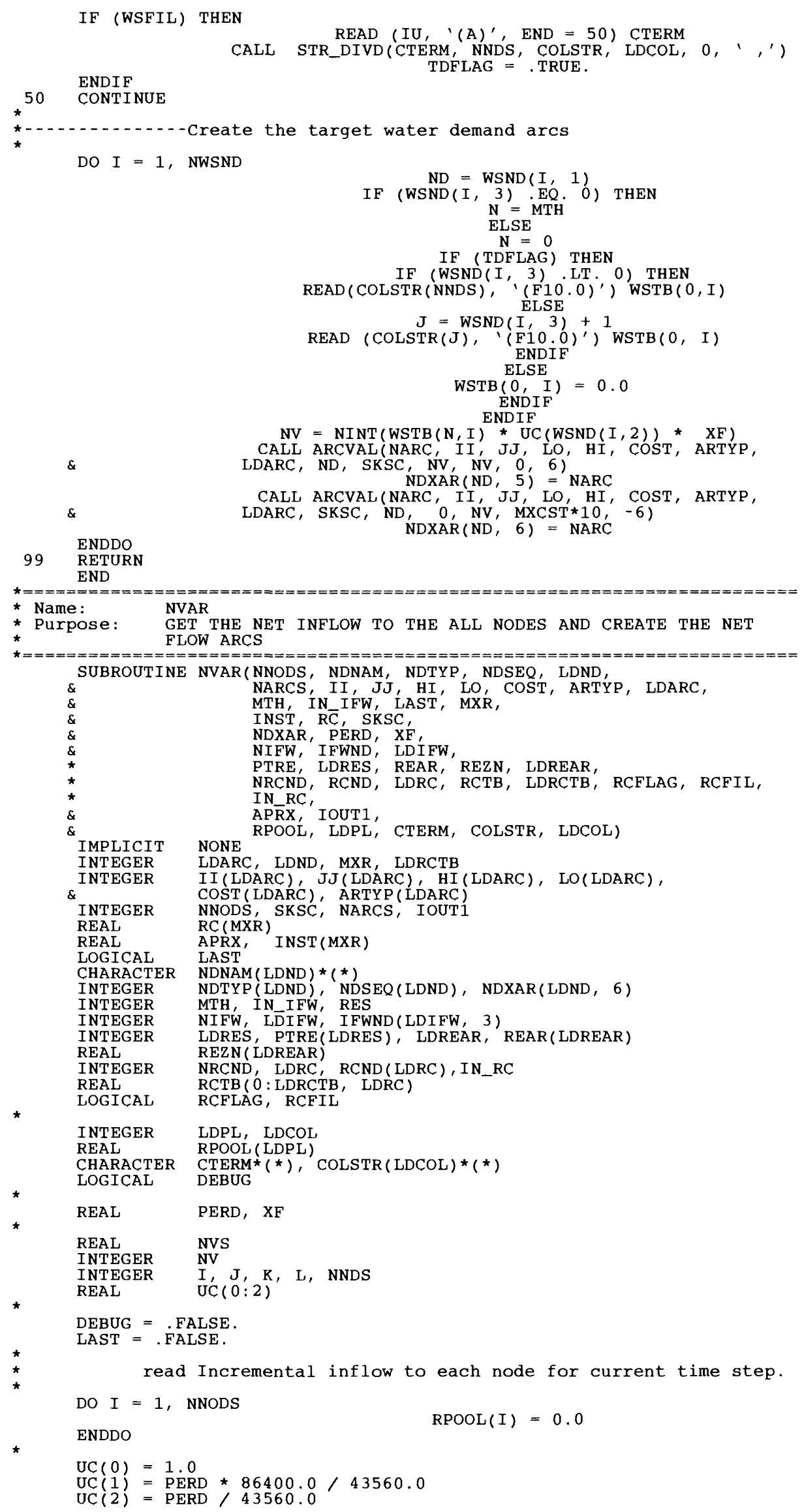




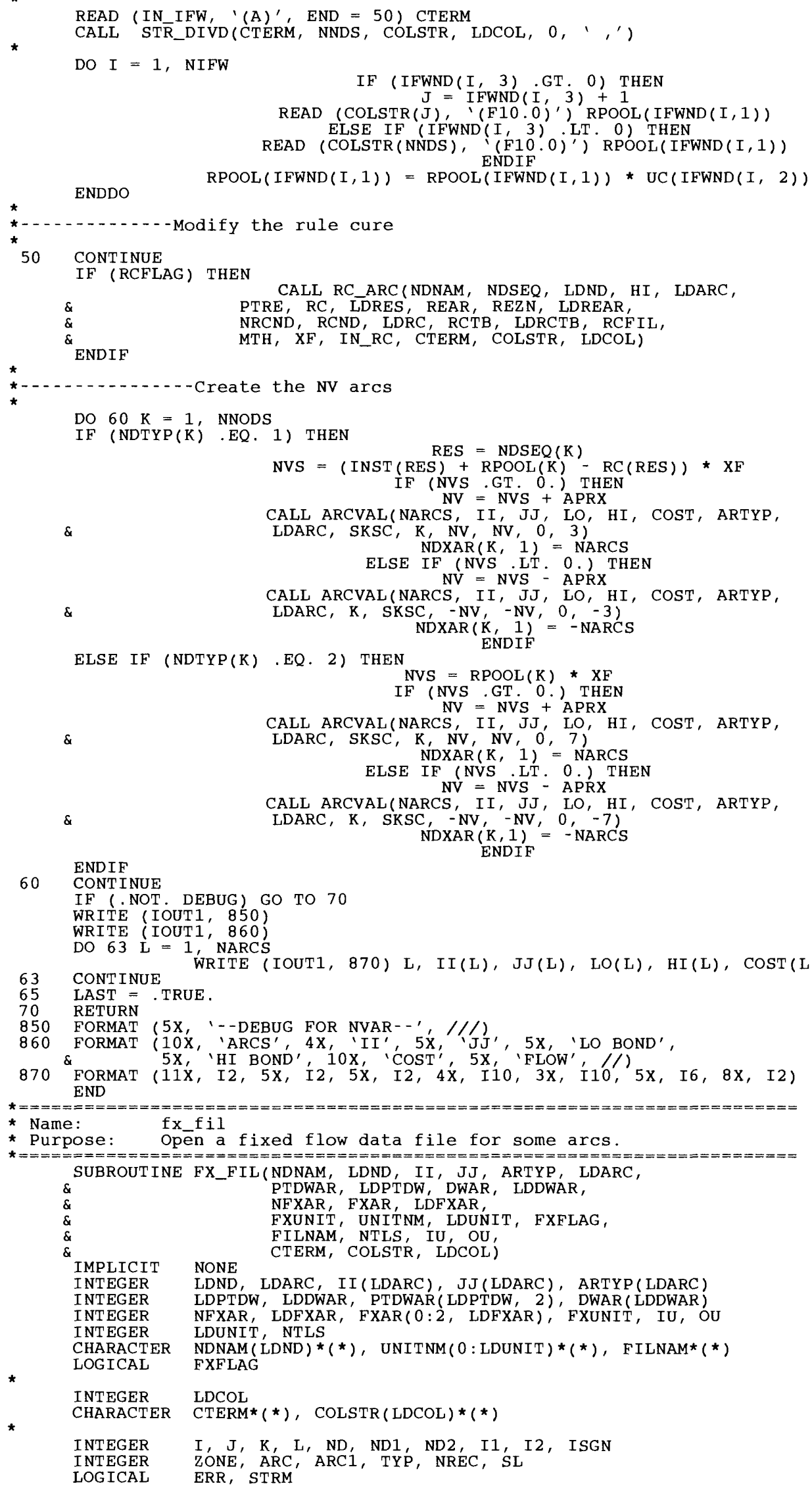

INTEGER INTEGER LOG ICAL

LDCOL

$\operatorname{CTERM} *(*), \operatorname{COLSTR}(\operatorname{LDCOL}) *(*)$

$\mathrm{I}, \mathrm{J}, \mathrm{K}, \mathrm{L}, \mathrm{ND}, \mathrm{ND} 1, \mathrm{ND} 2, \mathrm{I} 1, \mathrm{I} 2, \mathrm{ISGN}$

ZONE, ARC, ARC1, TYP, NREC, SL

ERR，STRM 


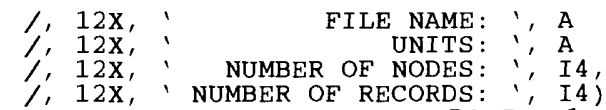

NUMBER OF RECORDS: '', I4'

$$
\begin{gathered}
\text { DO } \mathrm{J}^{\prime}=1, \text { NFXAR, } 5 \\
\mathrm{~K}=\mathrm{J}+4 \\
\mathrm{IF}((\mathrm{J}+4) \text { GT. NFXAR }) \text { THEN } \\
\mathrm{K}=\text { NFXAR } \\
\mathrm{ELSE}=\mathrm{J}+4 \\
\mathrm{~K}=\mathrm{J}+4
\end{gathered}
$$

WRITE (OU, 805) (NDNAM(FXAR(1, I)) $(1: \operatorname{SL}(\operatorname{NDNAM}(\operatorname{FXAR}(1, I))))$,

WRITE (OU, 806) (NDNAM(FXAR(2, I )) $(1: \operatorname{SL}(\operatorname{NDNAM}(\operatorname{FXAR}(2, I))))$,

$\& \quad$ WRITE $\quad I=\mathrm{J}, \mathrm{K}$ )

WRITE (OU, 808) ( $\operatorname{FXAR}(0, I), I=J, K)$

805 FORMAT (') UPSTREAM NODAL NAME:
806

806 FORMAT $(\vdots \quad$ DOWNSTREAM NODAL NAME:
808 FORMAT
ARC NUMBER:
ENDDO

99 CONTINUE

RETURN

END

$\begin{array}{ll}\star & ==== \\ \star & \text { Name: } \\ \star & \text { Purpose }\end{array}$

* Purpose:

fixflw

Read fixed flows and assign these flows into arc flow

bounds.

SUBROUTINE FX_ARC ( HI, LO, COST, LDARC, NFXAR, FXAR, LDFXAR,

\&

IMPLICIT NONE

FXUNIT, XF， PERD， IU,

INTEGER LDARC, HI (LDARC), LO(LDARC), COST(LDARC)

INTEGER NFXAR, LDFXAR, FXAR(0:2，LDFXAR)， FXUNIT， IU

REAL XE， PERD

INTEGER LDCOL, LDPL

REAL RPOOL (LDPL)

CHARACTER CTERM* $(*), \operatorname{COLSTR}(\mathrm{LDCOL}) *(*)$

REAL UC

INTEGER I, J, ARC

DO $I=1$, NFXAR

ENDDO (IU, ' (A)', END = 99) CTERM

CALL STR_DIVD (ĆTERM, I, COLSTR, LDCOL, 0, ', ')

IF (I .NE. (NFXAR +1) PRINT *, $\star * * \star$ ERROR *** FIXED FLOW FILE FOR TIME $=1, \operatorname{COLSTR}(1)$

ENDIF

IF (FXUNIT . EQ, O) THEN

ELSE IF (FXUNIT . EQ. 1) THEN

ELSE IF (FXUNIT . EQ. 2) THEN

ENDIF

$\mathrm{UC}=1.0$

DO $I=1$, NFXAR

ENDDO

$\operatorname{READ}(\operatorname{COLSTR}(I+1),((\mathrm{F} 15.0)$ ') RPOOL (I)

DO $\mathrm{J}=1, \mathrm{NFXAR}$

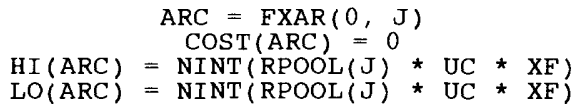

$99 \quad$ ENDDO

END

* Name.

* Purpose

sabl

Open files for single arc budget 1 ist.

SUBROUTINE SABL(NDNAM, LDND, PTDWAR, II, JJ, NDDWAR, LDARC

$\begin{array}{lll}\& & \text { NSTRM, STRMAR, LDSTRM, } \\ \& & \text { NSABL, SABLND, LDSABL, SABLFG, }\end{array}$

d

IMPLICIT

INTEGER LDND， LDARC， LDSTRM， LDSABL， NSABL

INTEGER

PTDWAR (LDND， 2)，II (LDARC)，JJ (LDARC)

NDDWAR (LDARC)， NSTRM，STRMAR(LDSTRM， $0: 6$ ),

SABLND (LDSABL，3)

$\begin{array}{ll}\text { NHARACTER } & \text { NDNAM(LDND)* }(*), \text { FILNAM* }(*) \\ \text { LOGICAL } & \text { SABLFG }\end{array}$

CHARACTER CTERM*50， UPDW $(2) \star 12, \operatorname{OUTFIL} * 12$

INTEGER I，J， NL(2), L1，L2，ND， ARC， OU, IU

LOGICAL

ERR 


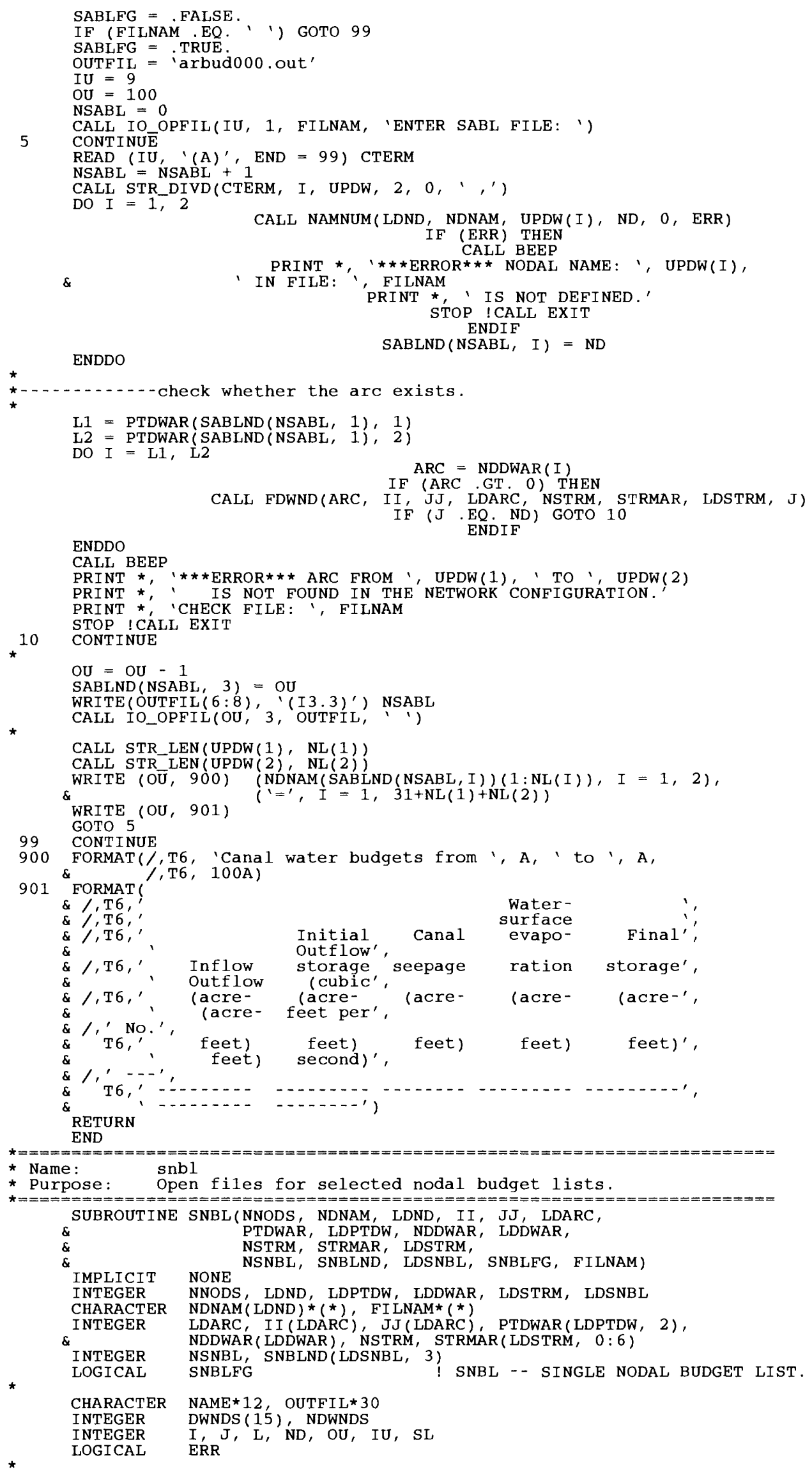


SNBLFG $=$. FALSE.

IF (FILNAM . EQ. 、 ') GOTO 99

SNBLFG $=$. TRUE:

$I U=9$

$\mathrm{OU}=40$

NSNBL $=0$

CALL IO_OPFIL(IU， 1， FILNAM, 'ENTER SNBL FILE: ')

CONTINUE

READ (IU, ' $(A)$ ', END = 99) NAME

CALL NAMNUM(NNODS, NDNAM, NAME, ND, 0, ERR)

IF (. NOT . ERR) THEN

NSNBL $=$ NSNBL +1

^

$$
\begin{aligned}
& \mathrm{OU}=\mathrm{OU}+1 \\
& \text { OUTFIL }=' \mathrm{~b} \cdot / / \mathrm{NAME} \\
& \text { CALL STR_LEN(OUTFIL, L) }
\end{aligned}
$$

-Open outflow file for a given node.

$$
\begin{gathered}
\text { OU }=\mathrm{OU}+1 \\
\text { SNBLND }(\text { NSNBL }, 3)=\mathrm{OU} \\
\text { OUTFIL }=\text { ' } r, / / \text { NAME }
\end{gathered}
$$

CALL STR_CORS (OUTFIL, 0)

CALL STR_LEN(OUTFIL, L)

OUTFIL = OUTFIL $(1: L) / /$ '. Out'

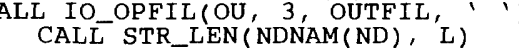

WRITE (OU, 905 ) NDNAM(ND), $(=,=1$ I $=1,14+\mathrm{L})$

CALL FDWNDS(ND, II, JJ, LDARC, PTDWAR,' LDND, NDDWAR, LDDWAR NSTRM, STRMAR, LDSTRM, NDWNDS, DWNDS )

WRITE(OU, 906) (NDNAM(DWNDS(I))(1:SL(NDNAM(DWNDS(I))))),

$906^{\&}$ FORMAT ( / , $5 \mathrm{X}, 20(4 \mathrm{X}, \mathrm{I} 1 \mathrm{~A} 12,4 \mathrm{X})$

WRITE (OU, ' $\left.(5 \mathrm{x}, 10(1 \mathrm{x}, 19 \mathrm{a} 1))^{\prime}\right)((1-,, \mathrm{J}=1,19), \mathrm{I}=1$, NDWNDS ) WRITE (OU, '(5x, $10(10 \mathrm{x}, \mathrm{a} 10))$ ') ('(cubic', I $=1$, NDWNDS ) WRITE(OU,' (5x, $\left.10(\mathrm{a} 10, \mathrm{a} 10))^{\prime}\right)$ 


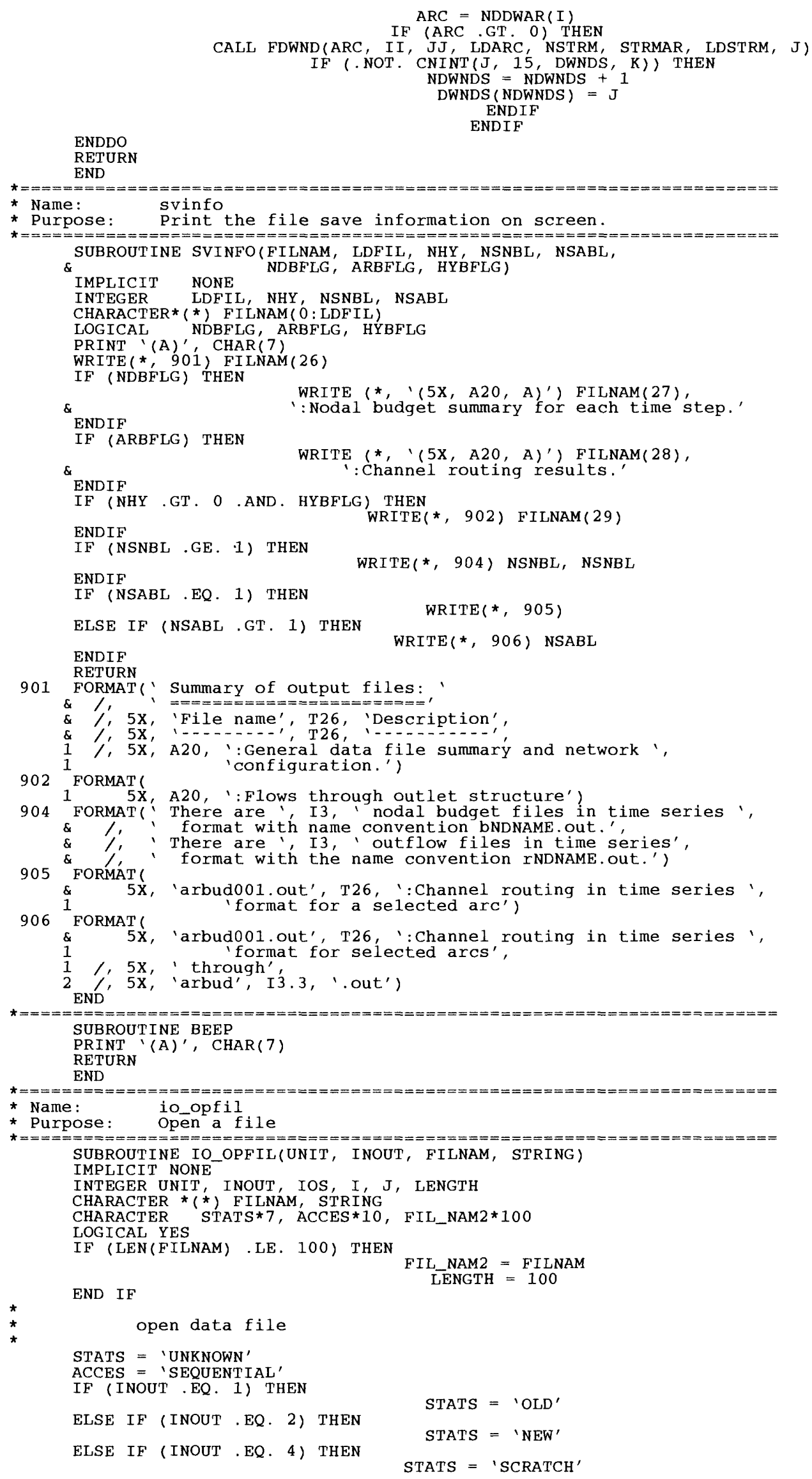


ELSE IF (INOUT . EQ. 6) THEN

END IF

$\mathrm{ACCES}=$ 'APPEND'

IF (FIL_NAM2 $(1: 1)$.NE. ' ') GO TO 10

2

ELSE

PRINT *, STRING

IF (INOUT . EQ. 1) THEN

PRINT * 'ENTER INPUT DATA FILE NAME :

ELSE IF (INOUT .EQ. 2) THEN

PRINT *, 'ENTER OUTPUT FILE NAME:

PRINT *, 'ENTER SCRATCH FILE NAME:

END IF

END IE

READ ' (A)', FIL_NAM2

IF (FIL_NAM2 $(1: \overline{1})$.EQ. CHAR(27)) THEN

ENDIF

DO 3 I $=1$, LENGTH

3 CONTINUE

PRINT *, $* * * * *$ ILLEGAL FILE NAME $* * * * *$ ZERO LENGTH FILE NAME'

$4 \quad$ CONT INUE

IF $((I-1)$.EQ . 0) THEN

ELSE

GO TO 10

DO $5 \mathrm{~J}=1$, LENGTH

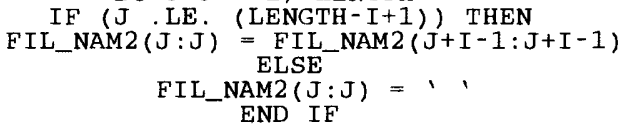

IF ( $J$. LE. (LENGTH-I+1)) THEN

END IE

CONT INUE

10

OPEN (UNIT, FILE = FIL_NAM2, STATUS = STATS, IOSTAT = IOS, ACCESS = ACCES

IF (IOS . NE. 0) THEN PRINT *, CHAR(7)

\& PRINT * $*$ FIL_NAM2 $2 * *$ ERROR $* * * * *$ FILE DOES NOT EXIST. FILE: ' PRINT ${ }^{*},{ }^{*}$ NAM 2 PLEASE TYPE ANY KEY TO TRY AGAIN OR TYPE CTR-C',

READ ' $(A)$ '

ELSE IF (INOUT THEN

$\&$

PRINT *, $* * * * *$ WARNING $* * * *$ THERE ALREADY EXISTS FILE: FIL_NAM2

PRINT *, DO YOU WANT TO OVERWRITE IT? (Y)

IF (YES()) THEN

STATS = 'UNKNOWN'

GO TO 10

ELSE

GO TO 2

END IF

END IF

END IF

IF (LEN(FILNAM) .GT. 6) THEN

ENDIF

RETURN

END

* Name.

* Purpose:

Yes

Response yes or no from keyboard.

* Purpose:

LOGICAL FUNCTION YES( )

IMPLICIT NONE

CHARACTER YESNO* 1

$\mathrm{YES}=$. FALSE

YESNO = 1

READ ' (A)', YESNO

IE (YESNO '.EQ. 'Y' .OR. YESNO .EQ. 'Y' .OR. YESNO .EQ. ' ') THEN

$\mathrm{ES}=$ TRUE

ELSE IF (YESNO .EQ. ' $N$ ' OR. YESNO .EQ. ' $n$ ') THEN

$\mathrm{YES}=$. FALSE

ELSE

$$
\text { GO TO } 10
$$

PRINT *, CHAR ( 7 )

$10-1$ RETUR

GO TO 5

END

* Name:

* Purpose:

No

Response no or yes from keyboard.

LOGICAL FUNCTION NO()

IMPLICIT NONE

CHARACTER YESNO * 1 


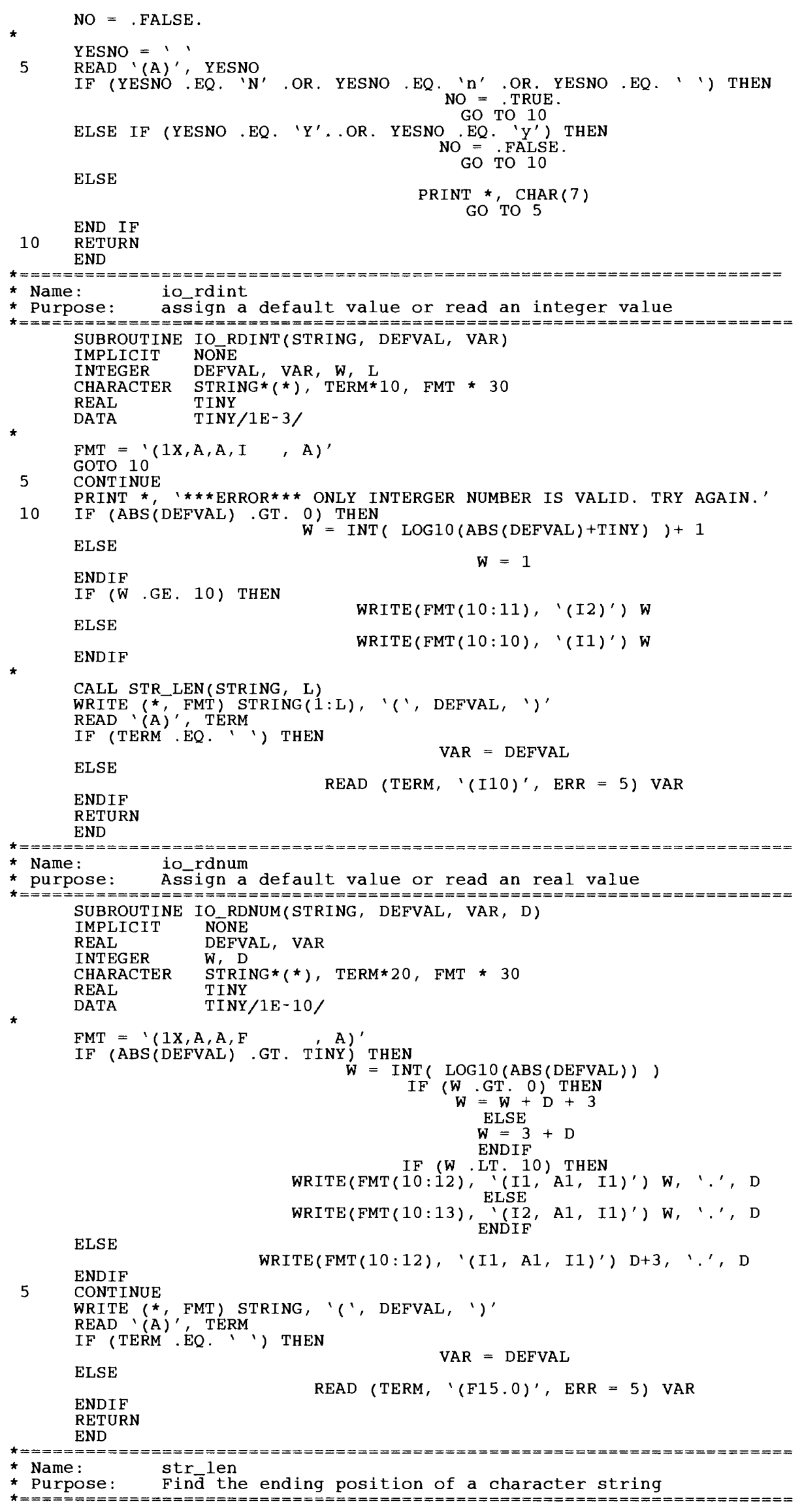


SUBROUTINE STR_LEN(STRING, STRLEN)

IMPLICIT NONE

CHARACTER STRING * ( *)

INTEGER STRLEN

IF (STRING . EQ. ' ') THEN

ELSE

STRLEN $=0$

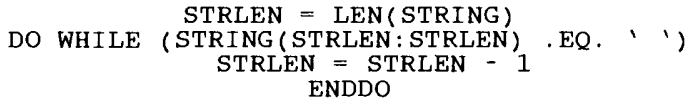

ENDIF

RETURN

END

$\star=====$
$\star$ Name: * purpose: $\begin{aligned} & \text { Divide a string into substrings with multiple } \\ & \text { delimitors. }\end{aligned}$

SUBROUTINE STR_DIVD(STRING，NOCOL，COLSTR，LDCOL， IALIGN，DELTM)

TMPLICIT NONE

INTEGER LDCOL, NOCOL， IALIGN

CHARACTER STRING*(*), COLSTR(LDCOL)*(*), DELIM* $(*)$

CHARACTER DLIM(15)*1

INTEGER STRING_LEN，COLSTR_LEN， I， J， K， L， NODLIM

LOGICAL ISDLIM

Find the no. of delimitors

$\mathrm{J}=\mathrm{LEN}(\mathrm{DELIM})$

DO $I=J, 1,-1$

ENDDO

$I=1$

5 NODLIM $=$

DO $I=1$, NODLIM

ENDDO

IF (DELIM(I:I) .NE. ' ') GOTO 5

Find the main string defined length and output substring length

DO $I=1$, LDCOL

END DO

$\operatorname{COLSTR}(I)=1$,

STRING LEN $=$ LEN (STRING)

COLSTR_LEN $=$ LEN $(\operatorname{COLSTR}(1))$

NOCOL $\cong 0$

Find the end position of the input main string

$I=$ STRING LEN

DO WHILE (STRING (I:I) .EQ. ' '

END DO

IF ( I EQ. 1) THEN

$$
\begin{gathered}
\text { IF (STRING }(1: 1) . \text { NE. ' ' THEN } \\
\text { NOCOL= I } \\
\text { COLSTR(1) }=\text { STRING }(1: 1) \\
\text { ENDIF } \\
\text { GO TO } 99
\end{gathered}
$$

ELSE

$E N D$ IF

STRING_LEN $=$ I

Find the beginning position of a substring

10 CONTINUE

$\mathrm{I}=\mathrm{J}+1$

11 CONTINUE

IF ( I . GT. STRING LEN) GO TO 99

DO $L=1$, NODLIM

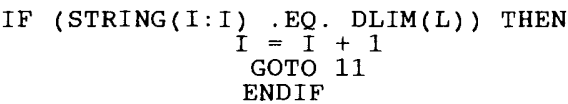

ENDDO

do while(string(i:i) .eq. ' ')

$i=i+1$

enddo

Find end position of a substring

$\mathrm{J}=\mathrm{I}+1$

NOCOL $=$ NOCOL +1

DO WHILE ( $J$. LE. STRING_LEN)

IF (ISDLIM(STRING (J:J), NODLIM, DLIM)) THEN

GOTO 20

$\mathrm{J}=\mathrm{JNDIF}+1$

ENDDO

$\mathrm{J}=\mathrm{J}-1$ 


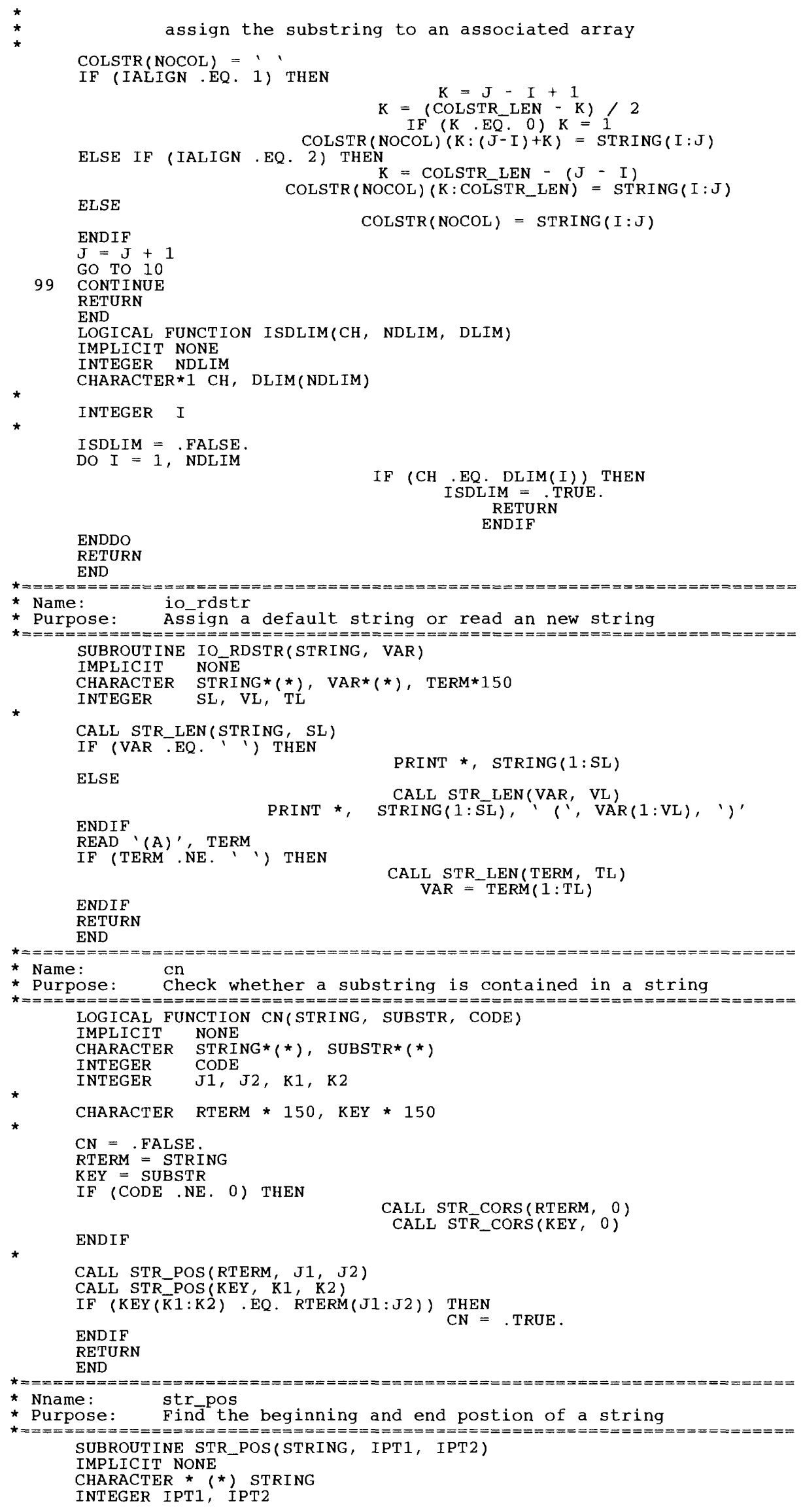


INTEGER I

IPT $2=$ LEN $($ STRING

DO $I=I P T 2,1,-1$

END DO

$5 \quad$ IPT2 $=$

DO $\mathrm{I}=1$, IPT2

END DO

IF (STRING(I:I) .NE. ' ') GO TO 5

10 IPT1 $=I$

RETUR

END

* Name :

str_cors

convert a string into capital latter or small latters.

SUBROUTINE STR_CORS(CLINE， ICTR)

IMPLICIT NONE

CHARACTER CLINE*(*)

INTEGER ICTR, CODE，L，I

CALL STR_LEN (CLINE， L)

DO $I=1, L$

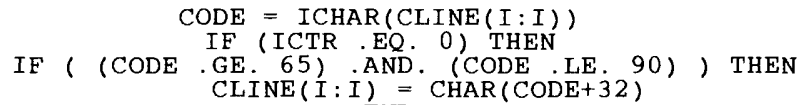

IF ( (CODE GE

$\operatorname{CLINE}(I: I)=\operatorname{CHAR}(\mathrm{CODE}-32)$

ENDIF

ENDDO

ENDIE

RETURN

* Name:

* purpose: Reture the number of substrings with multiple deliminators SUBROUTINE STR_NO(STRING， NOSUB， DELIM)

IMPLICIT NONE

INTEGER NOSUB

CHARACTER* (*) STRING, DELIM

CHARACTER * 1 DLIM(15)

INTEGER STRING_LEN，I，J，L， NODLIM

Initialize

NOSUB $=0$

Find the no. of delimitors

$\mathrm{J}=\mathrm{LEN}(\mathrm{DELIM})$

DO $I=J, 1,-1$

ENDDO

IF (DELIM(I:I) .NE. ' ') GOTO 5

$I=1$

5 NODLIM $=I$

DO $I=1$, NODLIM

ENDDO

$\operatorname{DLIM}(I)=\operatorname{DELIM}(I: I)$

Find the defined length for main string

STRING_LEN = LEN (STRING)

Find the true length of the input main string

$I=$ STRING LEN

DO WHILE (STRING (I:I) .EQ. ' '

END DO

IF (I . EQ. 1) THEN

$$
\begin{gathered}
\text { IF (STRING }(1: 1) \text { NE. ' ') THEN } \\
\text { NOSUB }=1 \\
\text { ELSE } \\
\text { NOSUB }=0 \\
\text { ENDIF } \\
\text { GO TO } 99
\end{gathered}
$$

ELSE

$E N D I E$
$J=0$

STRING_LEN $=I$

10 CONTINUE

find the beginning position of a substring

$I=\mathrm{J}+1$

15 CONTINUE

IE (I . GT. STRING_LEN) GO TO 99

IF (STRING $(I: I)$. EQ. ') THEN

$I=I+1$ 
GOTO 15

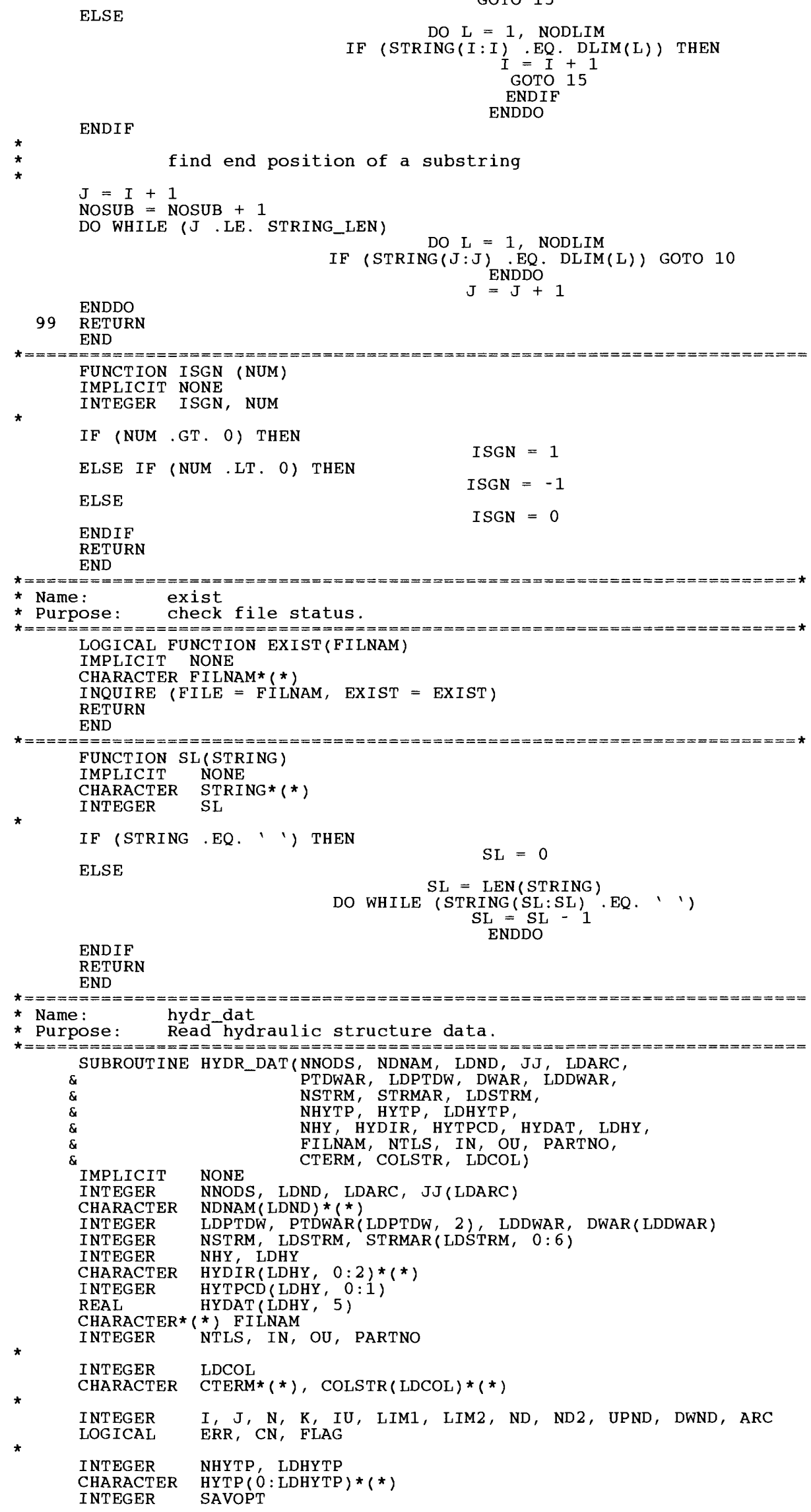

ELSE 
NHYTP $=6$

HYTP $(1)=$ 'Sharp-crested weir'

$\operatorname{HYTP}(2)=$ 'Gate spillway'

$\operatorname{HYTP}(3)=$ 'Sluice gate'

$\operatorname{HYTP}(6)=$ 'Pipe'

IF (FILNAM .NE. ' ' ') THEN

FLAG $=$. TRUE.

$I U=9$

CALL IO_OPFIL(IU, 1, FILNAM,'ENTER STRUCTURE FILE: ') DO $I=1$, NTLS

ELSE $\operatorname{READ}(\mathrm{IU}, \star$ END $=100)$ ENDDO

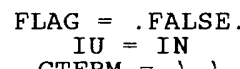

ENDIF ENDIF

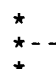

$$
\text { * }
$$

CALL NAMNUM (LDND, NDNAM, $\operatorname{HYDIR}(I, 1)$, UPND, 0, ERR) CALL NAMNUM(LDND, NDNAM, HYDIR $(I, 2)$, DWND, 0 , ERR) LIM1 $=$ PTDWAR (UPND, 1 ) 


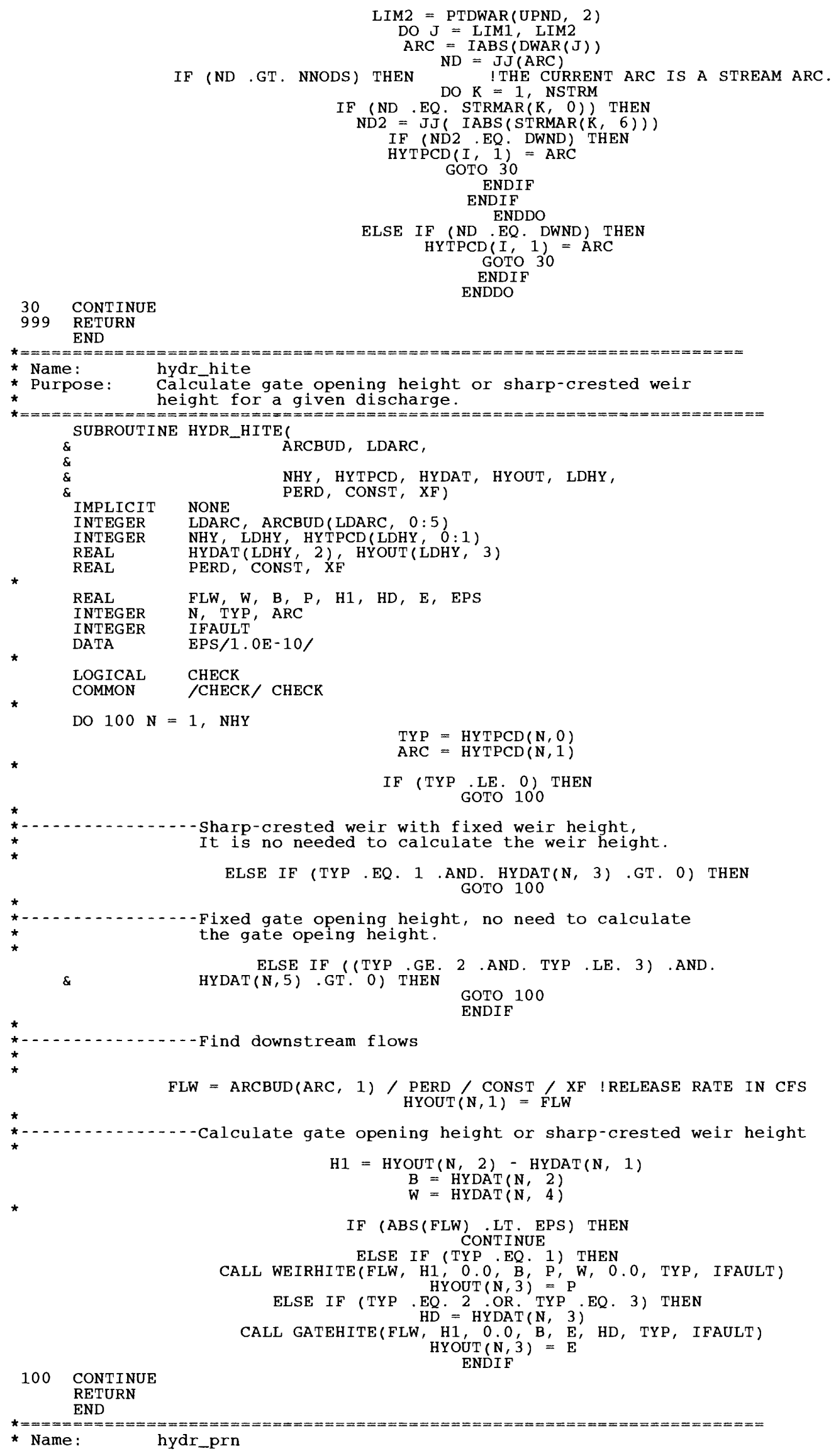


* Purpose: Print the results for flow through structure.

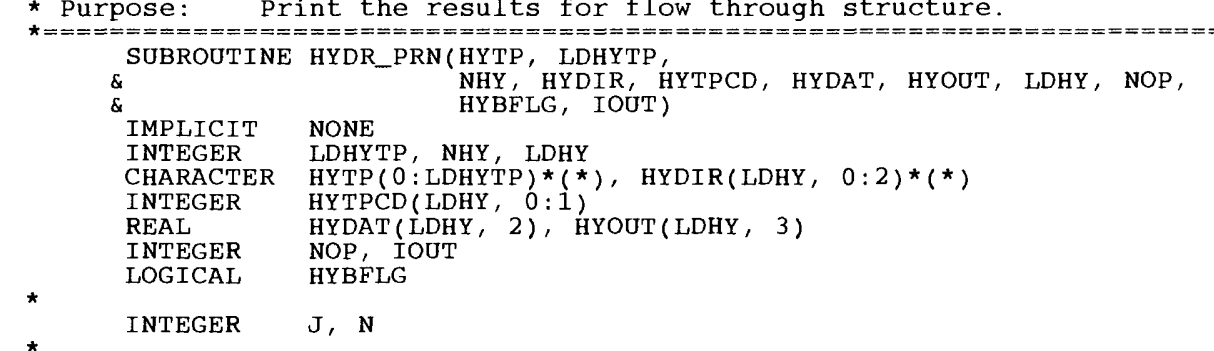

WRITE (IOUT, 900 ) NOP

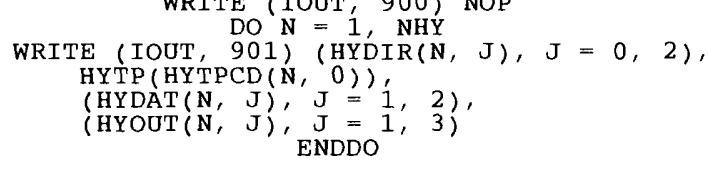

ENDIF

RETURN

900 FORMAT $(/, 20 \mathrm{X}$, 'Parameters for hydraulic structures: ', I3

\&

$\& \quad,, 20 \mathrm{x}$, ' [-999.99, not flow under gate]',

$\& /, \mathrm{T} 61, '$ ' Discharge Upstream Gate-opening',

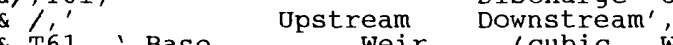

\& T61, Base Weir (cubic Water or weir ',

\& 'Structure node node', T41,'structure'

\& T61, elevation length feet per elevation height' '

\& 'name name T41,'type',

\& T61, (feet) (feet) second) (feet)', (feet)',

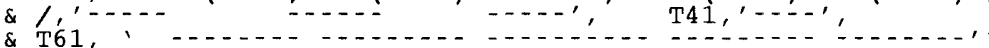

901 FORMAT(3A12, T41, A20, T61, 5F10.2)

END

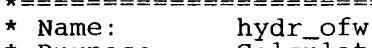

* Purpose: Calculate overflow on weir or through pipe. Flows are dependent

on ponds stages, and structure types and materials.

In other words, flows through structures can not be

controlled.

SUBROUTINE HYDR_OFW(NDSEQ, LDND,

$\&$ II, HI, LO, OHI, LDARC

$\S \quad$ NHY, HYTPCD, HYDAT, HYOUT, LDHY,

\& $\quad$ PERD, CONST, XF, OU

INTEGER LDND, NDSEQ(LDND),

$\&$

LDARC, I I (LDARC), HI (LDARC)， LO(LDARC)

INTEGER NHY, LDHY, HYTPCD(LDHY, $0: 1$ )

REAL HYDAT(LDHY, 5), HYOUT (LDHY, 3)

INTEGER LDRES

REAL OINST(LDRES)， PERD， CONST， XF

INTEGER

OU

REAL

INTEGER

LOGICAL

CHARACTER

COMMON

$B, W, P, H 1$, ZVA (3), D, L, F, E, LOFLW, HIFLW, HD

$\mathrm{N}$, TYP, ARC, ND, RES, IFAULT

GETZVA, CHECK

$\operatorname{NDNAM}(300) * 12$

/NDNAME/NDNAM

DO $100 \mathbf{N}=1, \quad$ NHY

$$
\begin{aligned}
\operatorname{TYP} & =\operatorname{HYTPCD}(\mathbf{N}, 0) \\
\operatorname{ARC} & =\operatorname{HYTPCD}(\mathrm{N}, 1) \\
\mathrm{ND} & =\operatorname{II}(\operatorname{ARC})
\end{aligned}
$$

*-1.2.-2.-.-Calculate upstream water depth

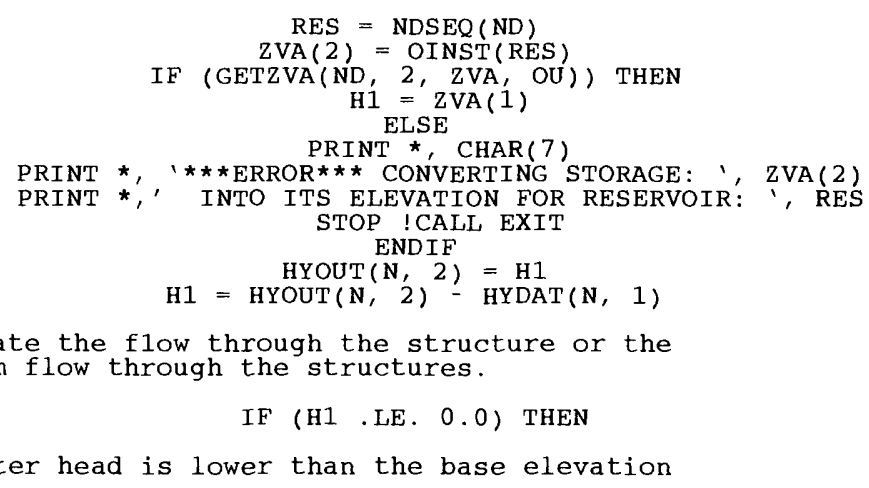




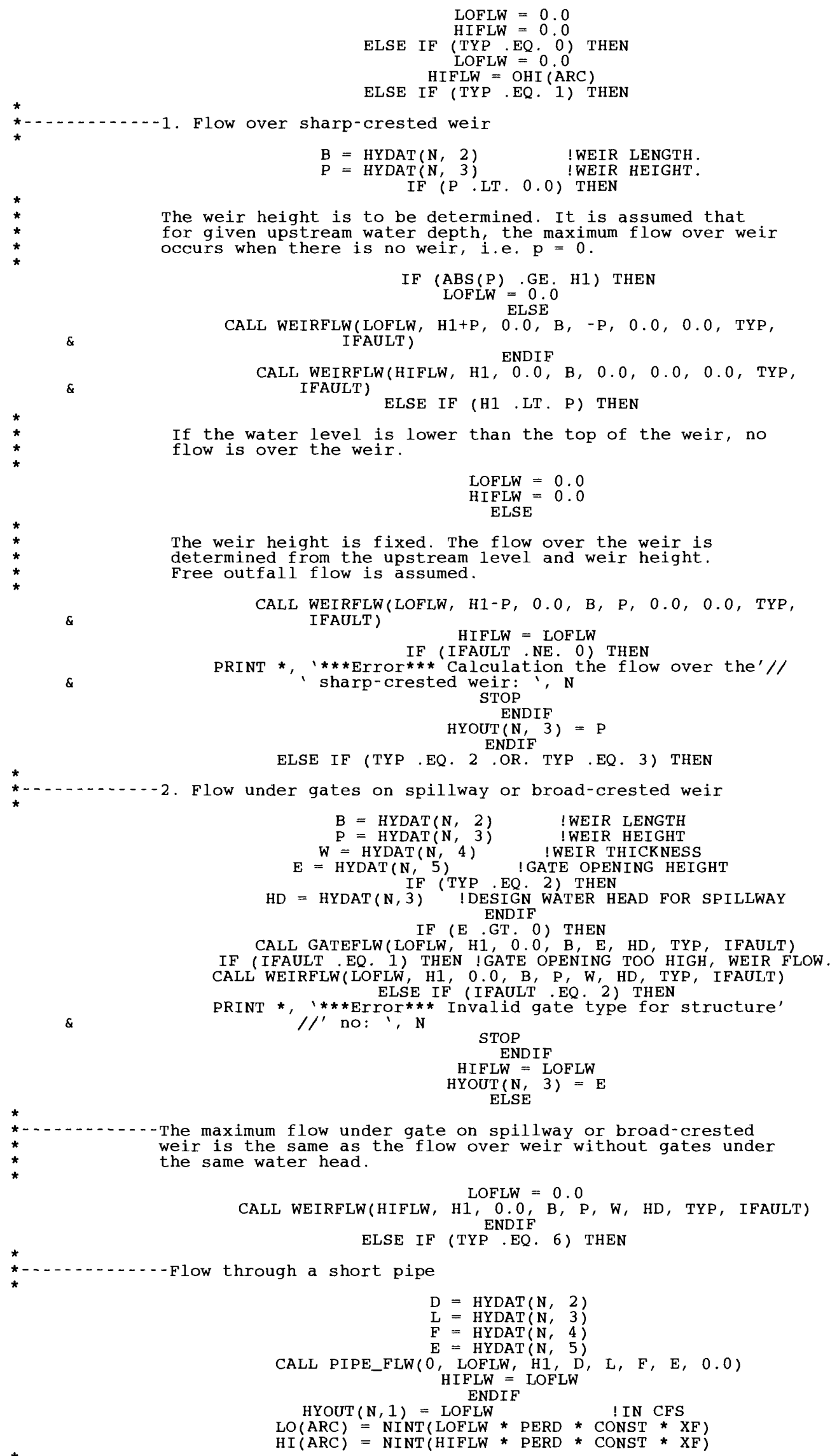




\section{CONTINUE END}

CHECK $=$. FALSE .

$*======$

resev_dat

* Purpose: Get séasonal reservoir surface water evaporation coefficient.

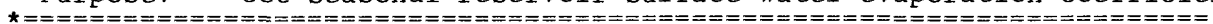

SUBROUTINE RESEV_DAT (NNODS, NDNAM, LDND, NEV, EVND, LDEV,

$\&$

NPER, EVTB， LDEVTB， EVUNIT, EVFLAG,

FILNAM, NTLS, IN, OU, PN,

UNITNM, LDUNIT, CTERM, COLSTR, LDCOL)

INTEGER NNODS, LDND, LDEVTB

CHARACTER * (*) NDNAM (LDND), FILNAM

INTEGER NEV, LDEV, EVND (LDEV, 3)， NPER, EVUNIT

INTEGER NTLS, IN, IU, OU, PN

REAL EVTB (0:LDEVTB, LDEV)

LOGICAL EVFLAG

INTEGER LDUNIT, LDCOL

CHARACTER UNITNM(0:LDUNIT)*(*), $\operatorname{CTERM} *(*), \operatorname{COLSTR}(\operatorname{LDCOL}) *(*)$

* INTEGER I, NREC

LOGICAL FLAG, ENDFIL

* EVFlag $=$. FALSE.

*.......-...-Open data file and skip title lines

$\star$

IF (FILNAM . NE. ' ') THEN

FLAG $=$.TRUE.

CALL IO_OPFIL(IU, I, FILNAM, 'ENTER SEASONAL EV DATA FILE: ')

$$
\text { DO } I^{\prime}=1, \underset{\text { REAL }}{\text { NTLS }}\left(\begin{array}{l}
\text { IU, *, } \\
\text { ENDDO }
\end{array}\right.
$$

ELSE

$$
\begin{aligned}
\text { FLAG } & =\text {. FALSE. } \\
\text { IU } & =\text { IN }
\end{aligned}
$$

CALL PNCK(PN, IU, ENDFIL, CTERM, COLSTR, LDCOL)

ENDIF

*-.-Read units, nonal names, and data from a file and

print these information into general output file.

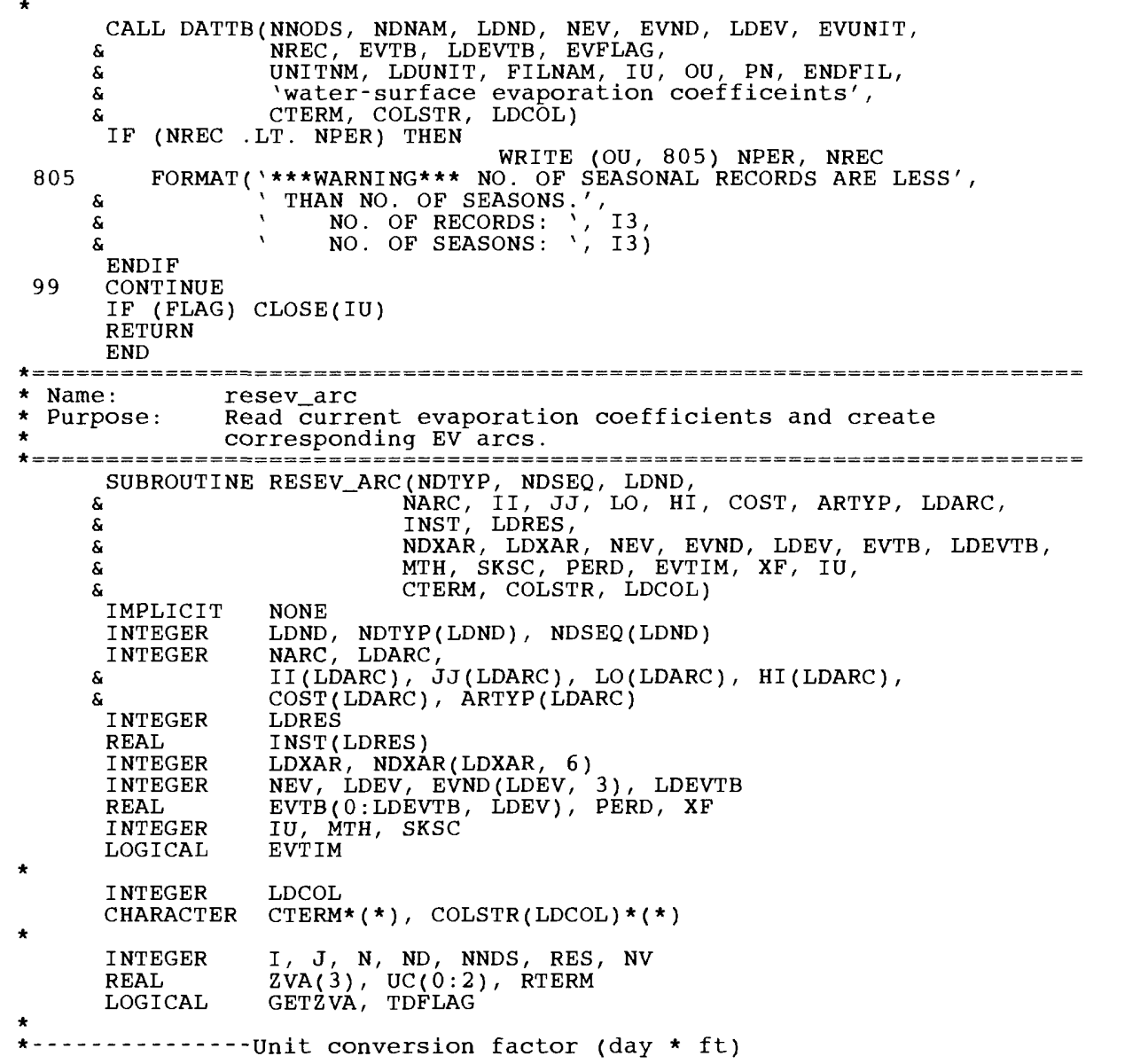




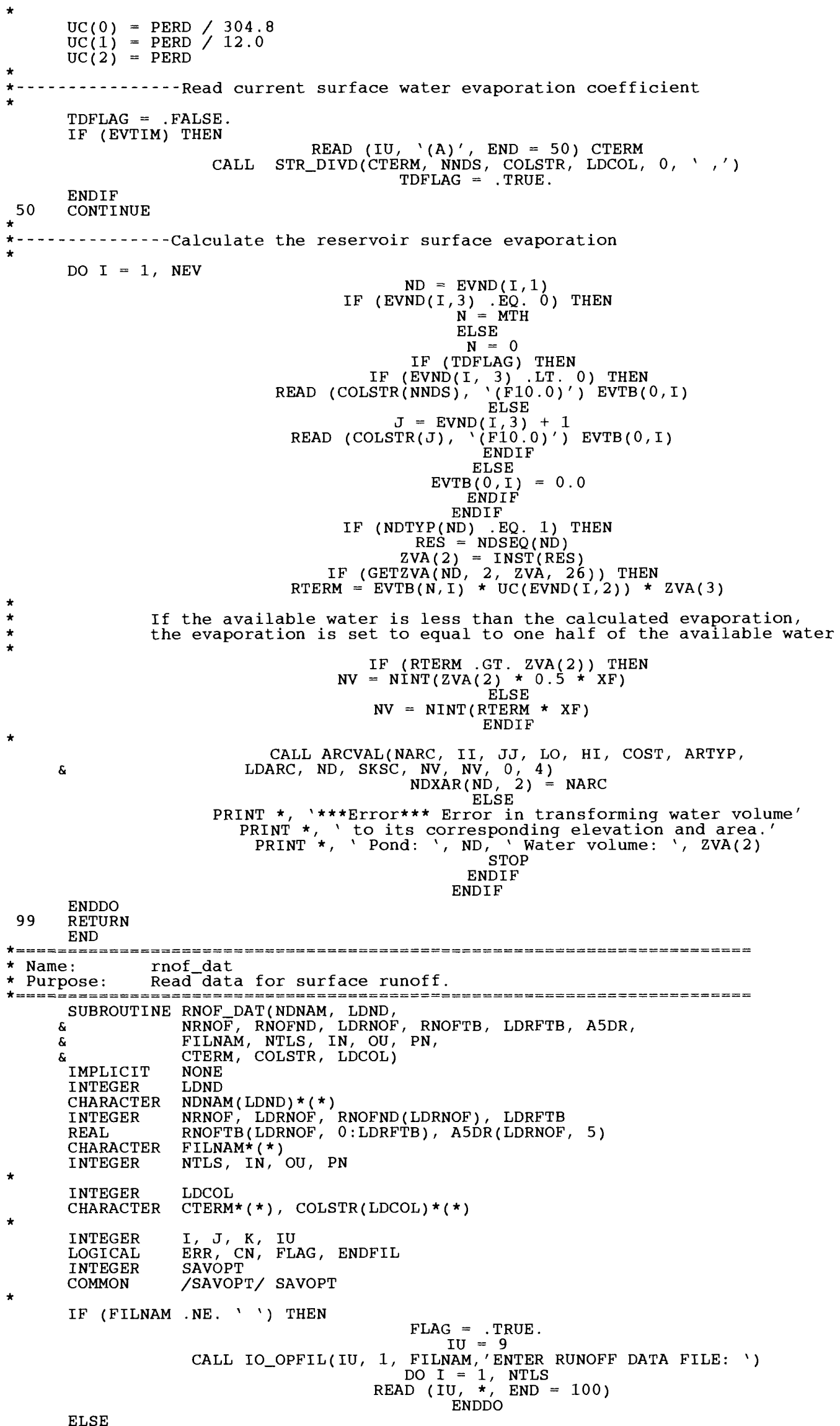




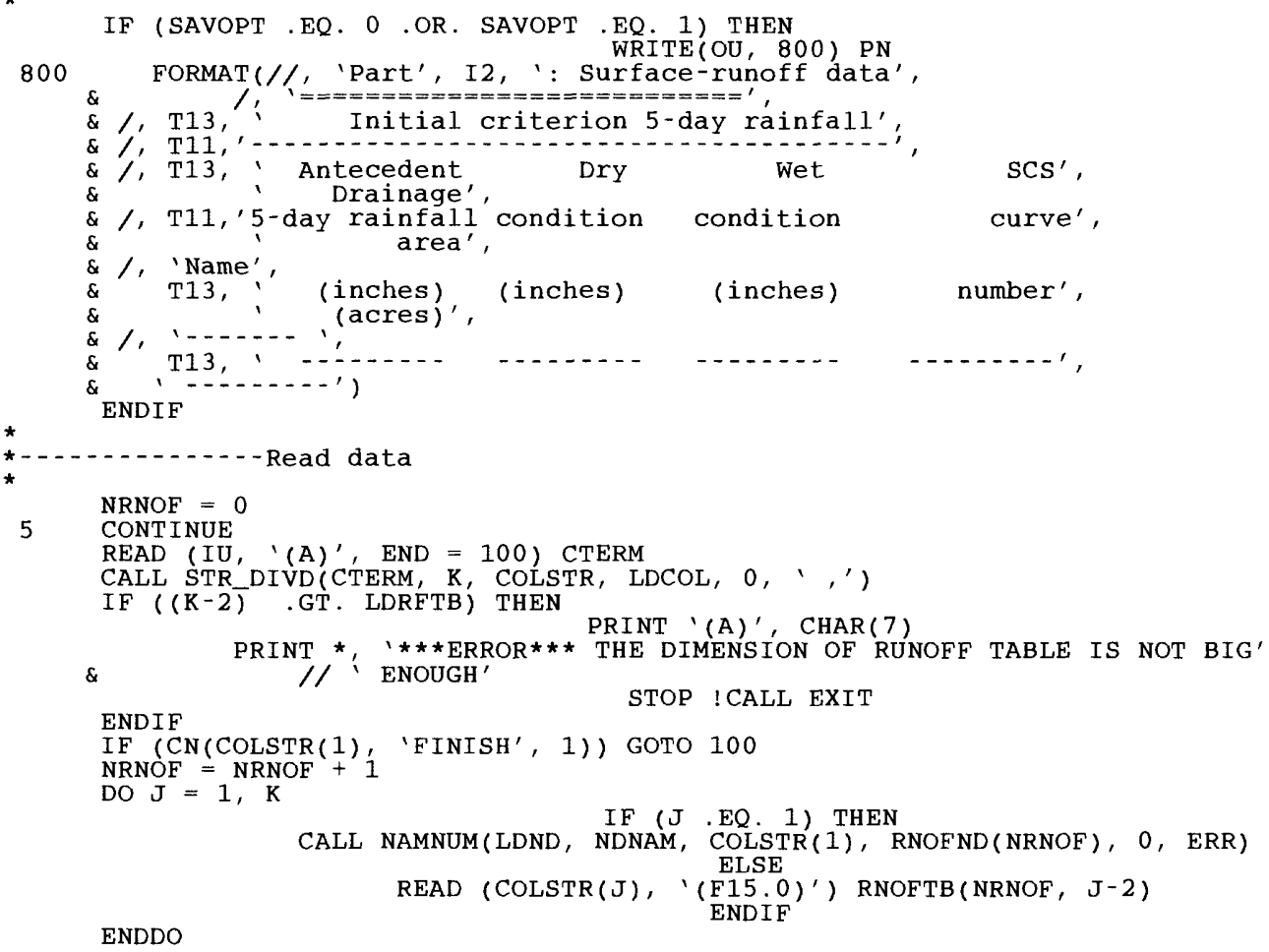

ENDDO

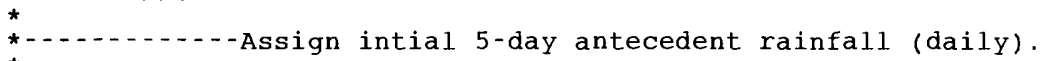




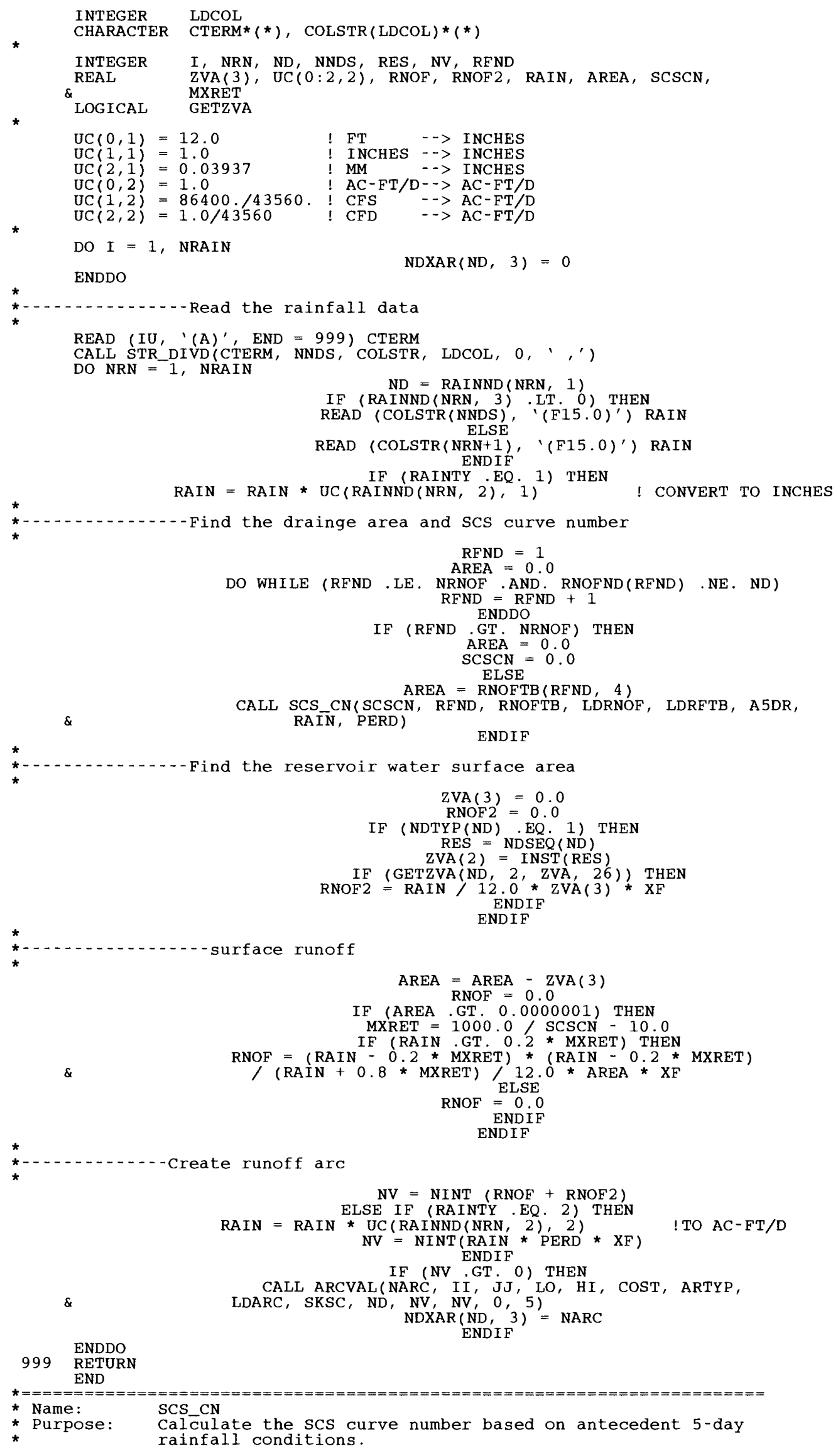




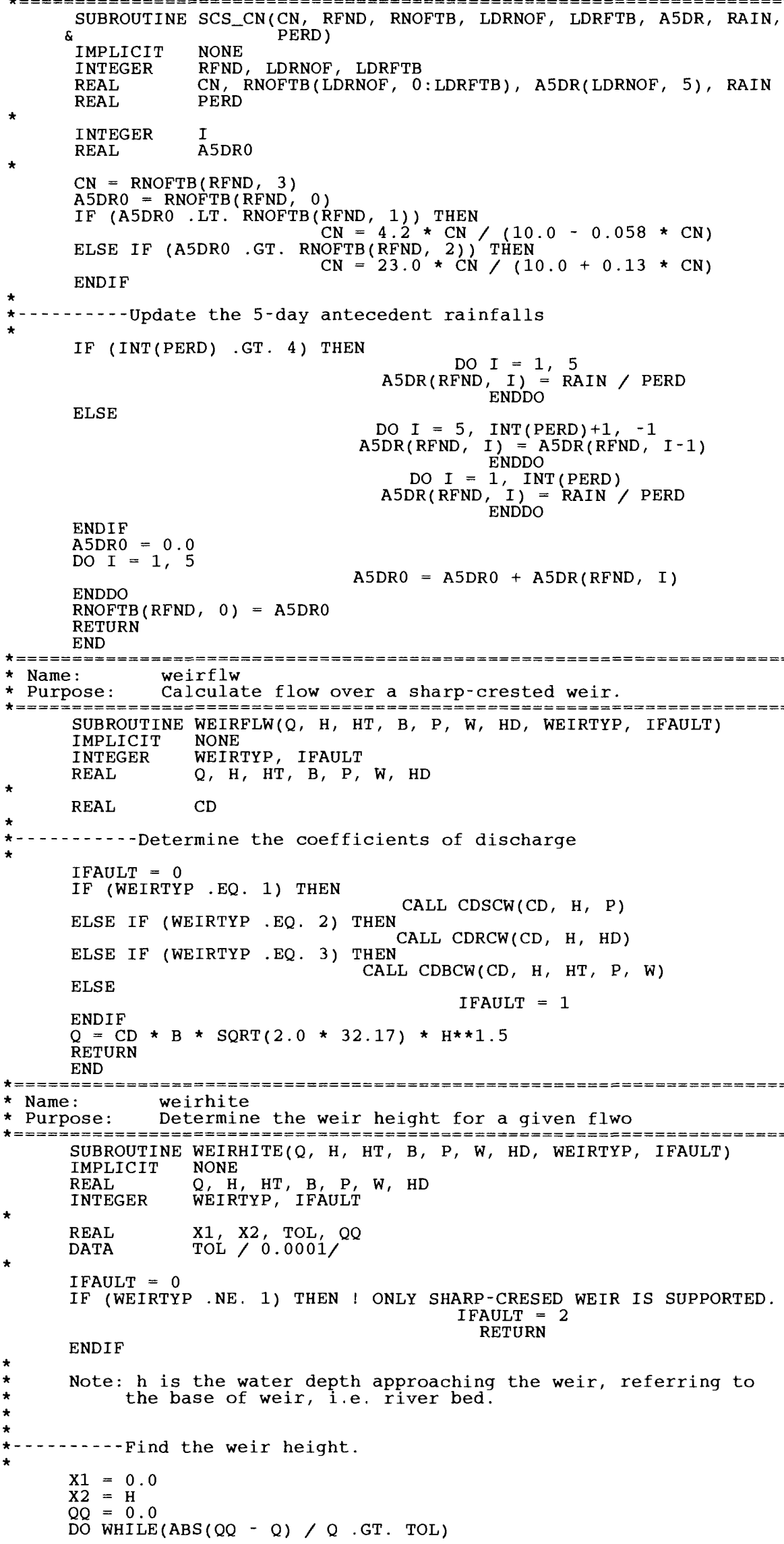


$\mathrm{P}=0.5 *(\mathrm{X} 1+\mathrm{X} 2)$

CALL WFIRFLW (OO, $\mathrm{H}-\mathrm{P}, \mathrm{HT}-\mathrm{P}, \mathrm{B}, \mathrm{P}, \mathrm{W}$ HD WEIRTYP, IFAULT)

IF (QQ . GT. O) THEN

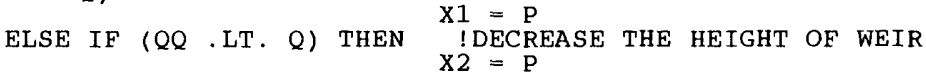
ENDIF

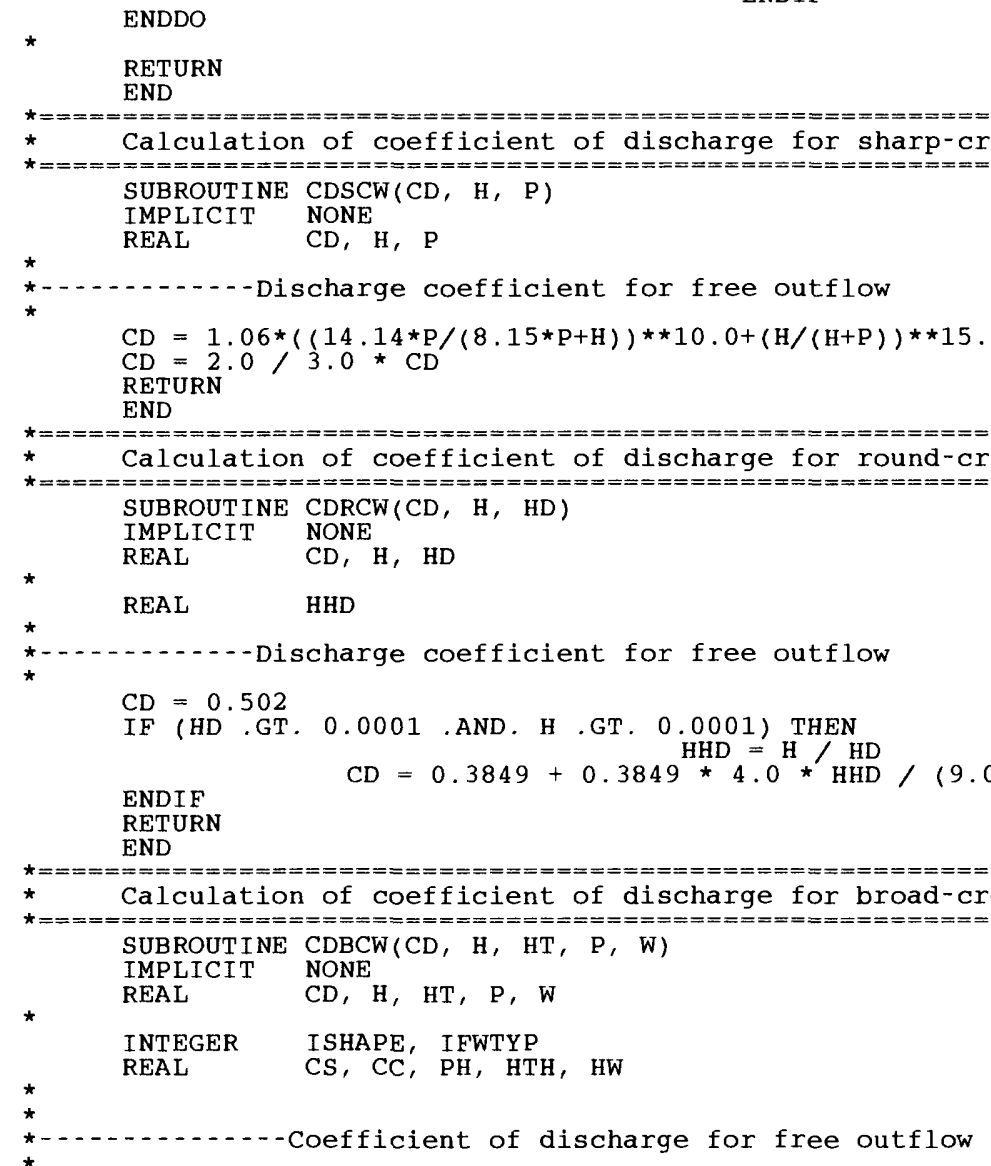

ENDDO

IF (W.GT. 0.00001$)$ THEN $\mathrm{HW}=\mathrm{H} / \mathrm{W}$
$\mathrm{CD}=0.5+0.1 *((\mathrm{HW} * \pm+5+1500.0 * \mathrm{HW} * 13) /(1.0+1000 * \mathrm{HW} * \star 3)) * \star 0.1$
$\mathrm{CD}=2.0 / 3.0 * \mathrm{CD}$

ELSE

$\mathrm{PH}=\mathrm{P} / \mathrm{H}$
ISHAPE $=0$
VERTICAL

IF (ISHAPE . EQ. O) THEN ! VERTICAL FACE WITH ROUNDED ENTRANCE.

IF $(\mathrm{PH}$. LE. 3) THEN $(3.0-\mathrm{PH}) /(1.2+1.5 * \mathrm{PH})$

$C D=0.36+0.01 * \underset{\text { ELSE }}{(3.0}$

$\mathrm{CD}=0.36$

ELSE IF (ISHAPE. EQ. 1) THEN ! VERTICAL FACE.
$\mathrm{CD}=0.32+0.01 *(3.0-\mathrm{PH}) /(0.46+0.75 * \mathrm{PH})$

$\mathrm{CD}=0.32+0.01 \star(3.0 \mathrm{ELSE}$

$\mathrm{CD}=0.32$

ENDIF

ENDIF ENDIF

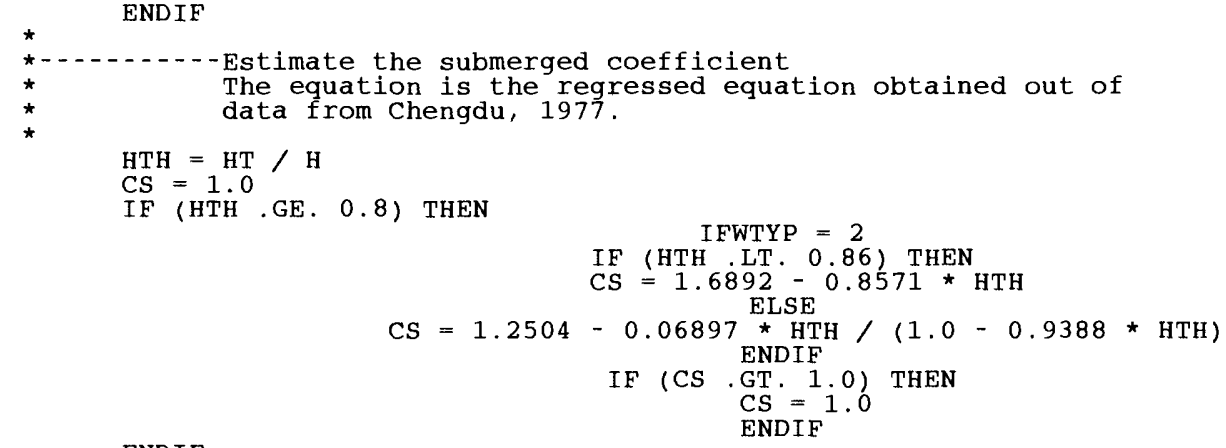

ENDIF 


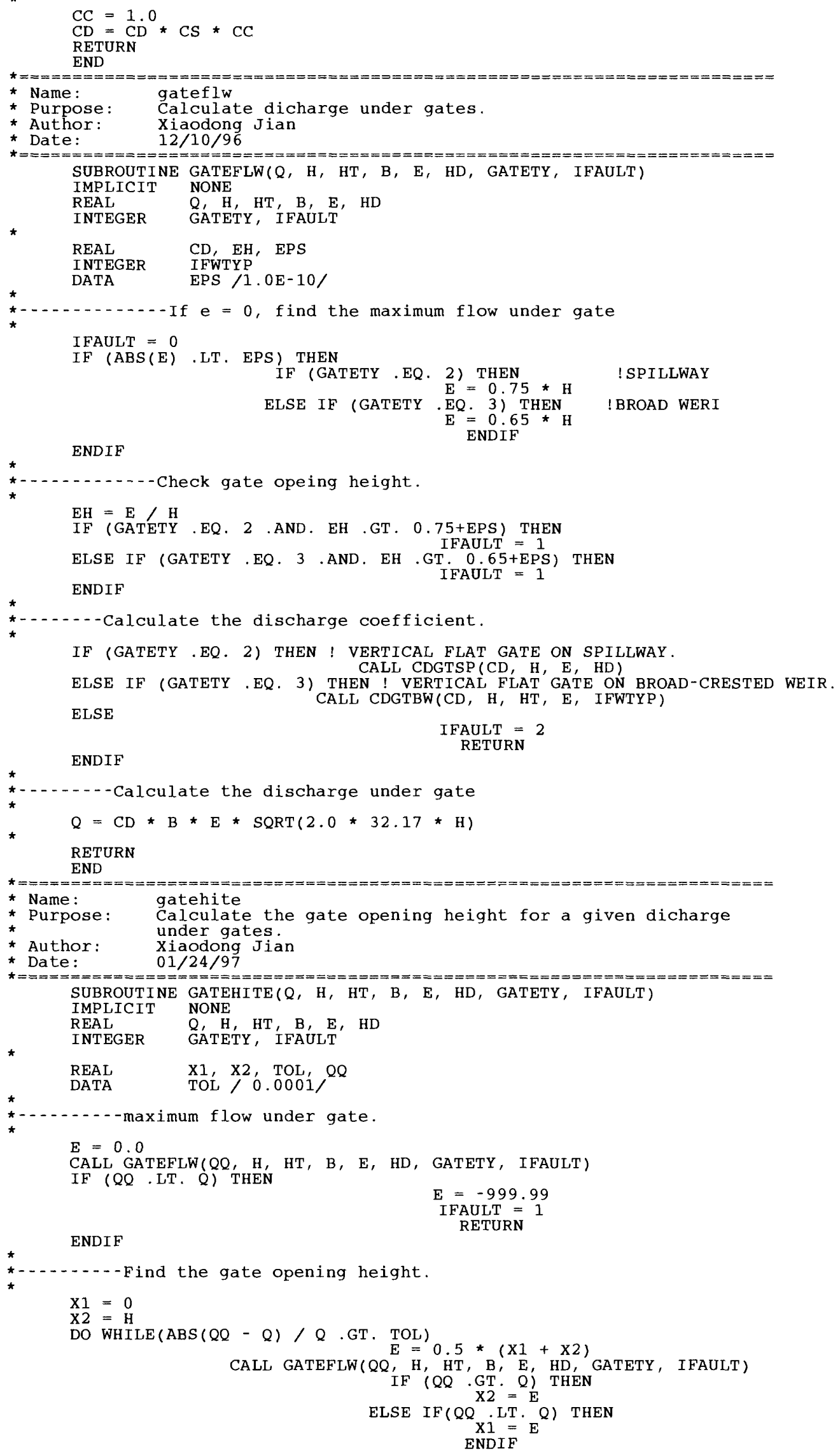




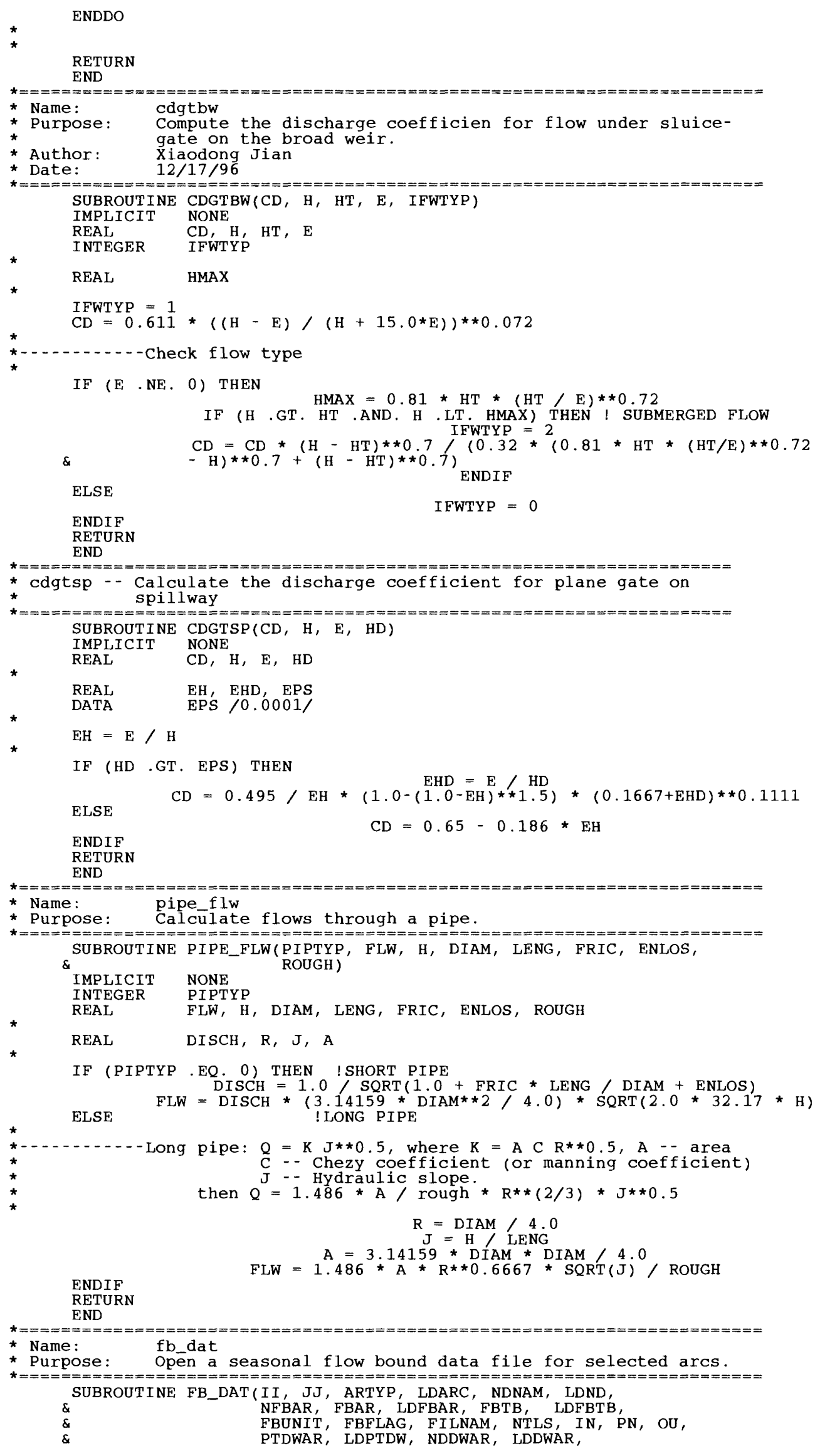


IMPLICIT NONE

INTEGER LDARC，II (LDARC)，JJ(LDARC)，ARTYP(LDARC)，LDND

CHARACTER NDNAM(LDND) * $(*)$, FILNAM* $(*)$

INTEGER NFBAR, LDFBAR, FBAR $(0: 7$, LDFBAR)，FBUNIT

INTEGER LDFBTB, LDPTDW, LDDWAR

REAL FBTB (0:LDFBTB， LDFBAR)

LOGICAL FBFLAG

INTEGER PTDWAR(LDPTDW, 2)，NDDWAR (LDDWAR)

INTEGER NTLS, IN, PN, OU, LDUNIT, LDCOI

CHARACTER* (*) UNITNM (0:LDUNIT)， CTERM， COLSTR (LDCOL)

INTEGER IU

INTEGER NREC, SL

INTEGER $\mathrm{I}, \mathrm{J}, \mathrm{K}, \mathrm{L}, \mathrm{M}, \mathrm{N}$

LOGICAL ERR, FLAG, ENDFII

LOGICAL CN

INTEGER SAVOPT

COMMON /SAVOPT/ SAVOPT

FBFLAG $=$. FALSE.

NFBAR $=0$

*........-...-open data file and skip title lines

IF (FILNAM . NE. ' ') THEN FLAG $=$. TRUE.

CALL IO OPFIL(IU, 1, FILNAM,'ENTER SEASONAL FLOW BOUND FILE: ') DO I $=1$, NTLS
READ (IU, *,
ENDDÓ

ELSE

FLAG $=$ IU FALSE.

CALL PNCK(PN, IU, ENDFIL, CTERM, COLSTR, LDCOL)

ENDIF

IF' (ENDFIL) GOTO 99

CALL FB_HED(NDNAM, LDND, II, JJ, ARTYP, LDARC,

$\& \quad$ NFBAR, FBAR, LDFBAR, FBUNIT,

$\& \quad$ ENDFIL,

\& PFDWAR， LDPTDW， NDDWAR，LDDWAR， FILNAM， IU,

IF (ENDFIL) GOTO 99

FBFLAG $=$. TRUE

*

NREC $=0$

CONTINUE

READ (IU, '(A)', $E N D=99$ ) CTERM

IF (CN (CTERM, 'EINISH', 1)) GOTO 99

CALL STR_DIVD(CTERM， J, COLSTR，LDCOL，0，'，')

IF ( $J$. NE. (NFBAR + 1) ) THEN

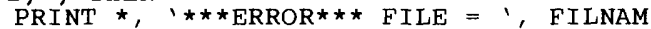

PRINT *, $\quad$ FOR TIME $=1, \operatorname{COLSTR}(1)$

ENDIF

STOP !CALL EXIT

NREC $=$ NREC +1

DO $\mathrm{J}=1$, NFBAR

ENDDO

GOTO 30

CONTINUE

IF (FLAG) CLOSE(IU)

(1)

IF (NREC .GT . O) THEN

$\begin{array}{ll}\text { ENDFIL } & =\text {. FALSE } \\ \text { FBFLAG } & =\text {. TRUE. }\end{array}$

IF (SAVOPT EO 0 .OR. SAVOPT .EO 1) THEN

CALL STR_LEN (UNITNM (FBUNIT), K)

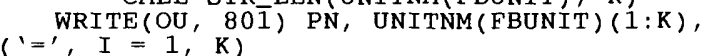

$801 \&$ FORMAT $/ /, \quad$ ' ' ' $=\prime, I=1, \mathrm{I})$

$\&$

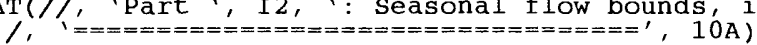

$\mathrm{DO} \mathrm{K}=1, \quad \mathrm{NFBAR}, 8$

$$
\text { IF } \begin{aligned}
&((\mathrm{K}+7)\text {. GT. NFBAR }) \text { THEN } \\
& \mathrm{L}= \text { NFBAR } \\
& \mathrm{ELSE} \\
& \mathrm{L}=\mathrm{K}+7 \\
& \text { ENDIF }
\end{aligned}
$$

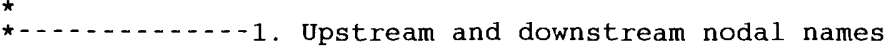
WRITE (OU, 805) ' Upstream node: ',
WRITE(OU, 805) ' Downstream node: '
$(\operatorname{NDNAM}(\operatorname{FBAR}(2, \mathrm{~J}))(1: \operatorname{SL}(\operatorname{NDNAM}(\operatorname{FBAR}(2, J)))), \mathrm{J}=\mathrm{K}, \mathrm{L})$ FORMAT (A, T20, 10A12) 


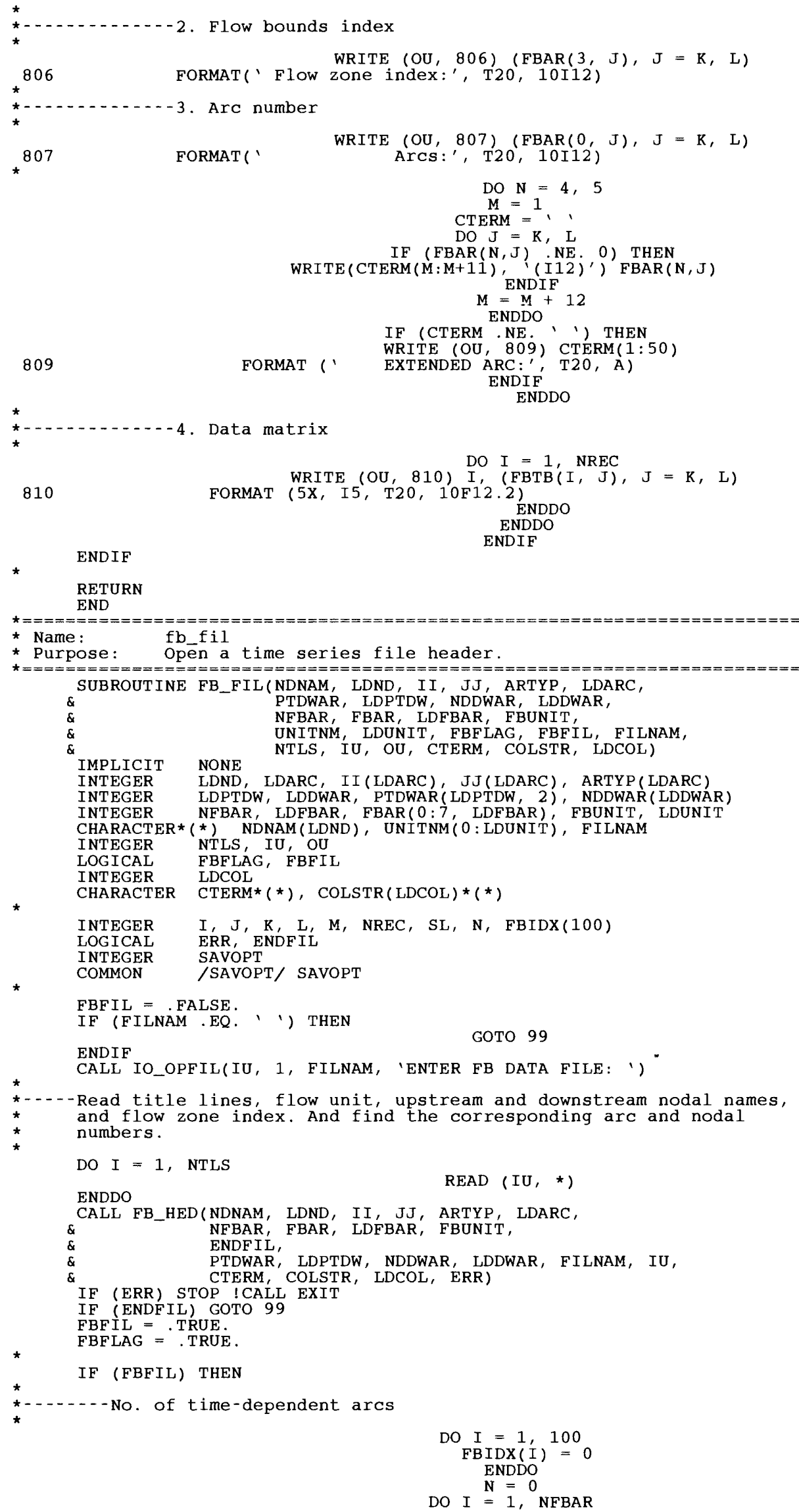




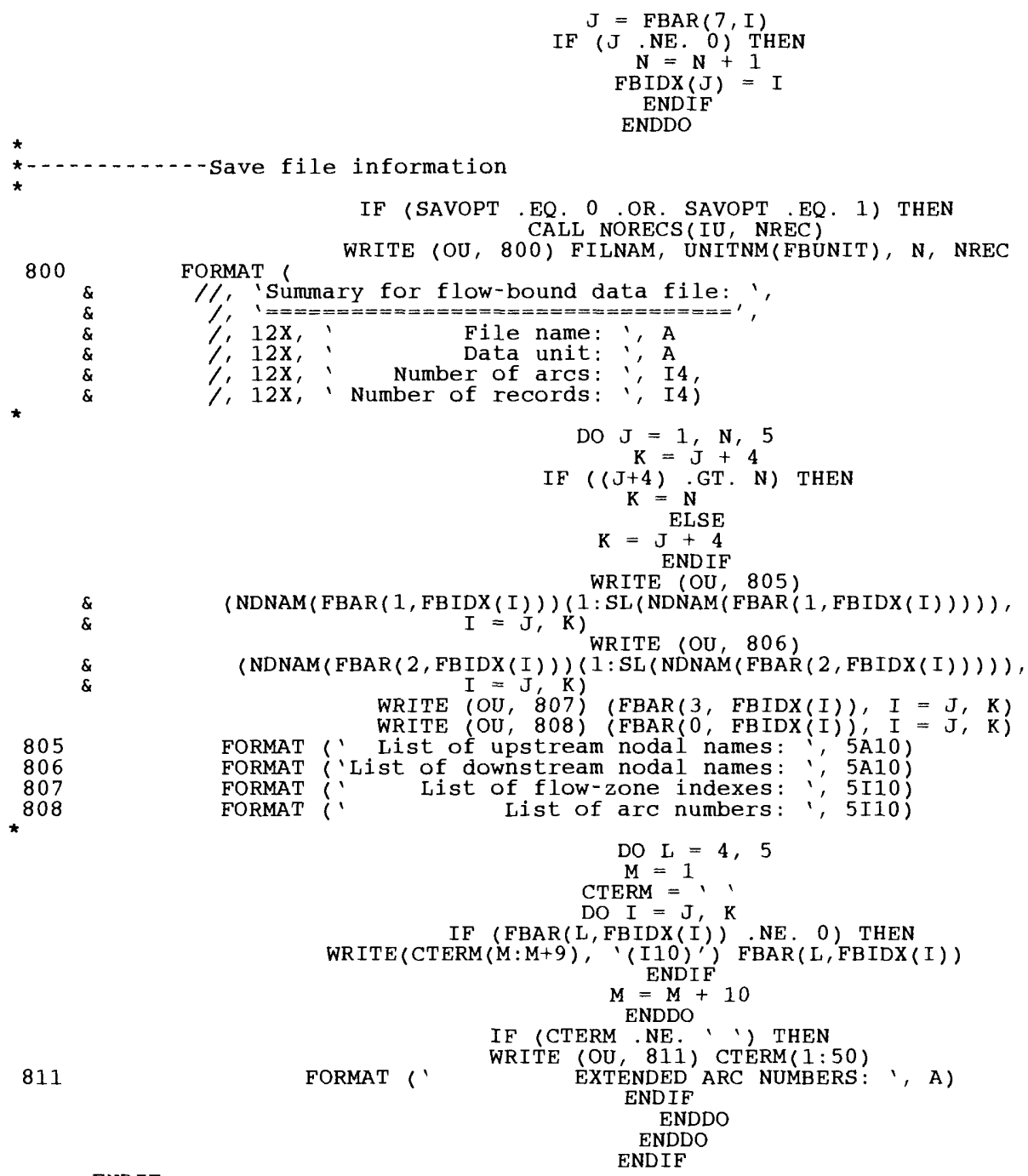




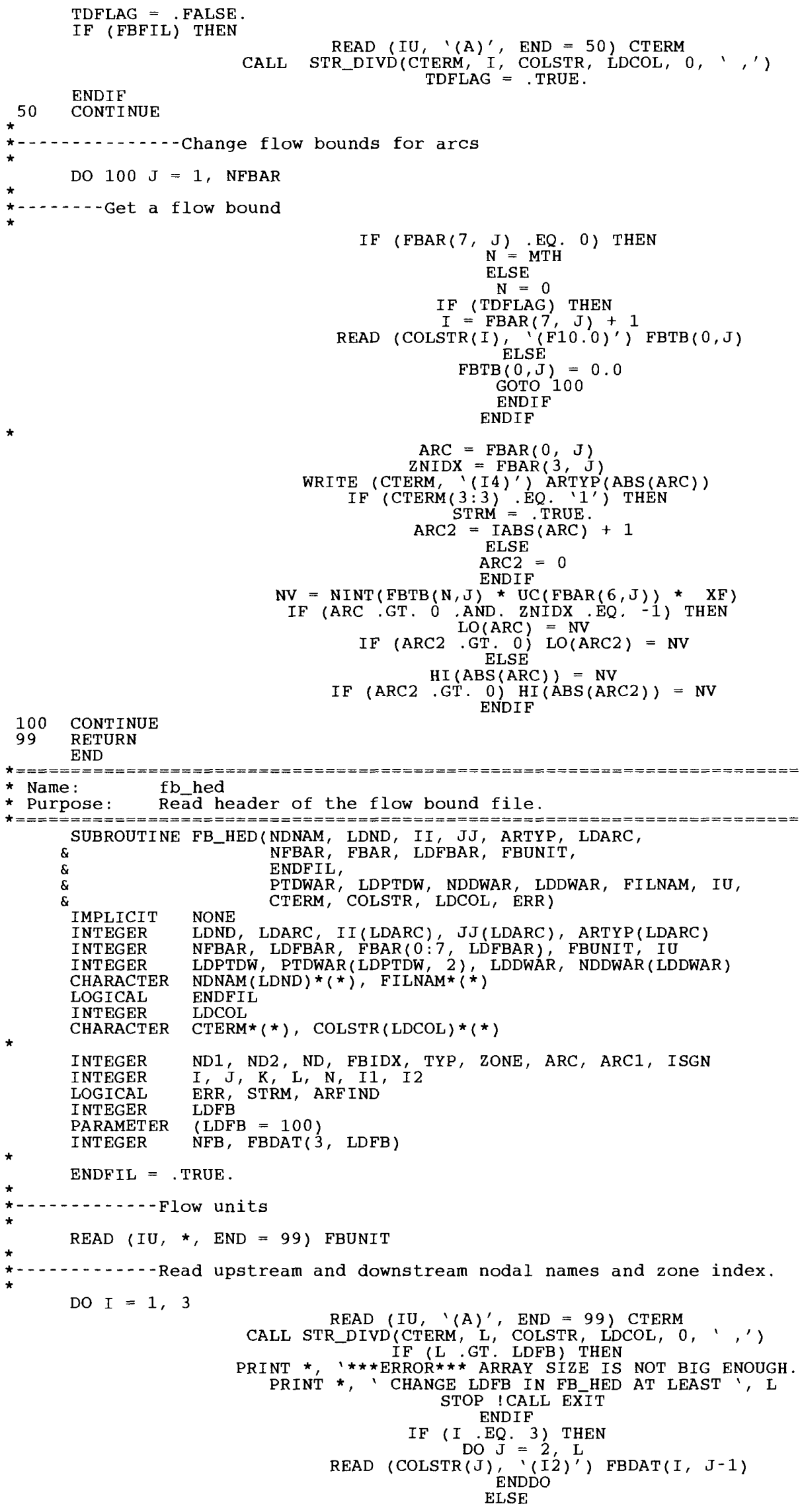




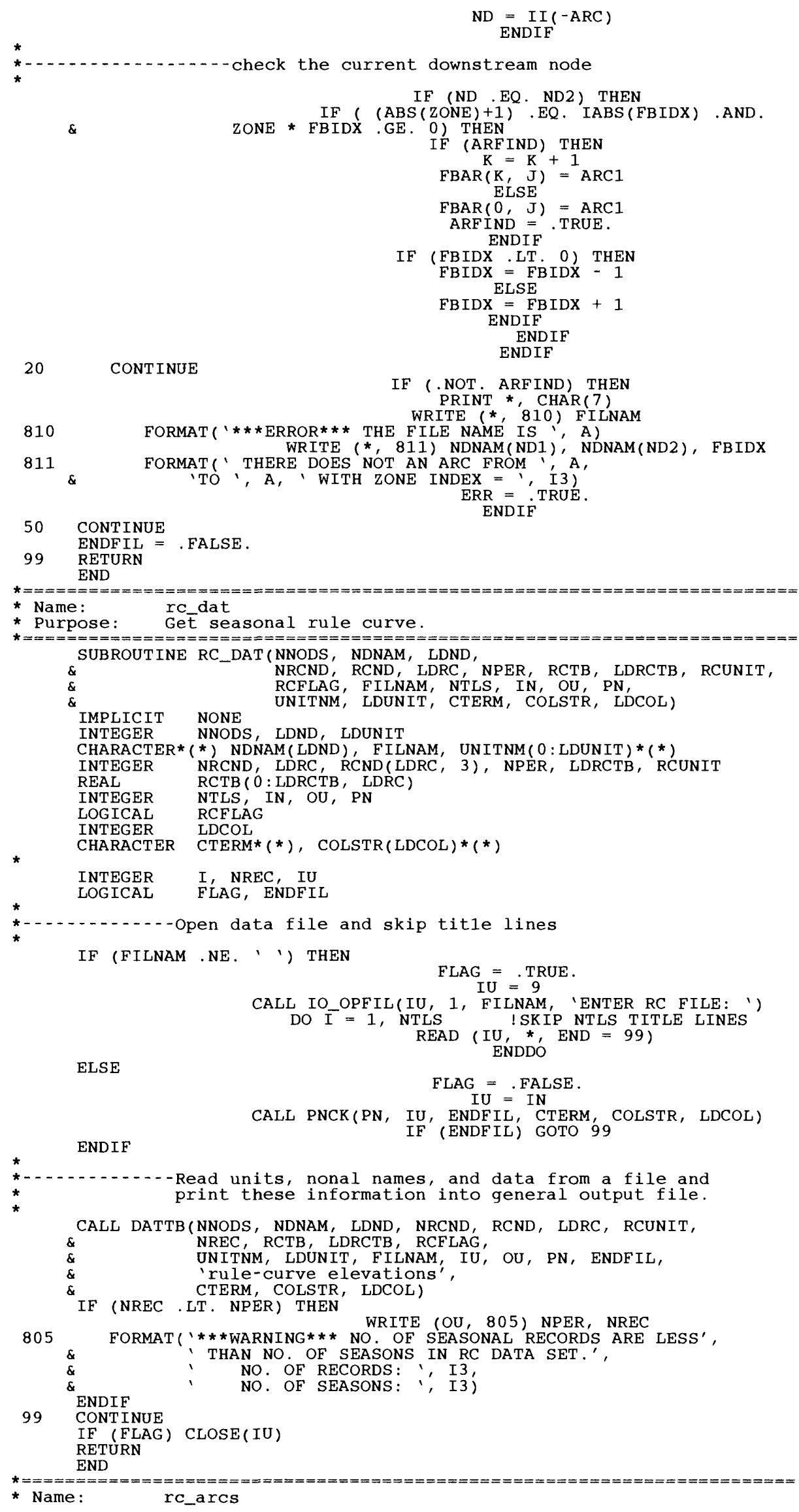


* Purpose: Read current target water demand and create corresponding TwS arcs.

$\&$

(NDNAM, NDSEQ, LDND, HI, LDARC,
PTRE, RC, LDRES, REAR, REZN, LDREAR

NRCND， RCND， LDRC, RCTB， LDRC'TB， RCFIL,

IMPLICIT NONE

MTH, XF, IU, CTERM, COLSTR, LDCOL)

INTEGER LDND, NDSEQ(LDND)， LDARC, HI (LDARC)

CHARACTER NDNAM(LDND) * $(*)$

$\begin{array}{ll}\text { INTEGER } & \text { LDRES, PTRE (LDRES), LDREAR, REAR(LDREAR) } \\ \text { REAL } & \text { RC(LDRES), REZN(LDREAR) }\end{array}$

INTEGER

REAL

LOGICAL

RC (LDRES), REZN (LDREAR)

NRCND， LDRC， RCND(LDRC，3)，LDRCTB

RCTB ( 0 : LDRCTB， LDRC)

RCFIL

INTEGER

REAL

IU, MTH

INTEGER LDCOL

CHARACTER CTERM* (*), COLSTR (LDCOL)* $(*)$

$\begin{array}{ll}\text { INTEGER } & I, J, J 1, J 2, N, \text { ND, NNDS, RES, ARC } \\ \text { REAL } & \text { ZVA(3), UC }(0: 2), \text { UPZN, LOZN, ZN }\end{array}$

LOGICAL

GETZVA', FIRSTL, FIRSTU, TDFLAG

$\mathrm{UC}(0)=1.0$

$\mathrm{UC}(1)=1.0 / 12.0$

$\mathrm{UC}(1)=1.0 / 12.0$
$\mathrm{UC}(2)=1.0 \% 304.8$

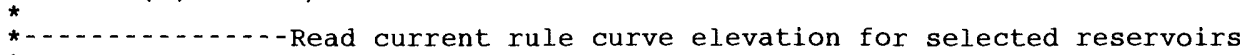

TDFLAG $=$. FALSE

IF (RCFIL) THEN

READ (IU,' (A)', END = 50) CTERM

CALL STR_DIVD(C'TERM, NNDS, COLSTR, LDCOL, 0, ', ')

ENDIE

TDFLAG $=$. TRUE

50 CONTINUE

*

DO $I=1, N R C N D$

$\mathrm{ND}=\operatorname{RCND}(\mathrm{I}, 1)$

IF (RCND (I, 3) . EQ. 0) THEN

$\mathrm{N}=\mathrm{MTH}$

LSE

$\mathrm{N}=0$

IF (TDFLAG) THEN

IF (RCND (I, 3) . LT. 0) THEN

ELSE

$\mathrm{J}=\operatorname{RCND}(\mathrm{I}, 3)+1$

ELSE

$\operatorname{READ}\left(\operatorname{COLSTR}(J),(F 15.0)^{\prime}\right) \operatorname{RCTB}(0, I)$

ENDIF

$\operatorname{RCTB}(0, I)=0.0$

$\operatorname{ZVA}(1)=\operatorname{RCTB}(N, I) * \operatorname{UC}(\operatorname{RCND}(I, 2))$

$\mathrm{RES}=\mathrm{NDSEQ}(\mathrm{ND})$

IF (. NOT. GETZVA(ND, 1, ZVA, 26)) THEN

PRINT *, CHAR ( 7)

PRINT *, $1 * \star \star E R R O R * *$ * TRANSFORM Z-V-A:'

PRINT *, $\quad$ POND $=1, \operatorname{NDNAM}(N D)$

ENDIF

PRINT * । RC $=1, \mathrm{ZVA}(1)$

$\mathrm{J} 1=$ PTRE (RES)

$\mathrm{J} 2=\operatorname{PTRE}(\operatorname{RES}+1)-1$

FIRSTL $=$. TRUE

FIRSTU $=$. TRUE

$\mathrm{UPZN}=\mathrm{ZVA}(2)$

$\operatorname{LOZN}=\operatorname{ZVA}(2)$

DO $\mathrm{J}=\mathrm{J} 1, \mathrm{~J} 2$

$\mathrm{ARC}=\operatorname{REAR}(\mathrm{J})$

$\mathrm{ZN}=\operatorname{REZN}(\mathrm{J})$

IF (ARC.TT O) THEN

$\mathrm{HI}(-\mathrm{ARC})=\mathrm{NINT}((\mathrm{LOZN}-\mathrm{ZN}) * \mathrm{XF})$

IF (HI (-ARC) . LT. O) THEN

ELSE

$\mathrm{LOZN}=\mathrm{ZN}$

ELSE

E IF (ARC .GT. 0) THEN

$H I(A R C)=N I N T((Z N-U P Z N) * X F)$

IF (HI(ARC).LT. O) THEN

ELSE $I(A R C)=0$

UNDTF

ENDIF

$\mathrm{PZN}=\mathrm{ZN}$ 


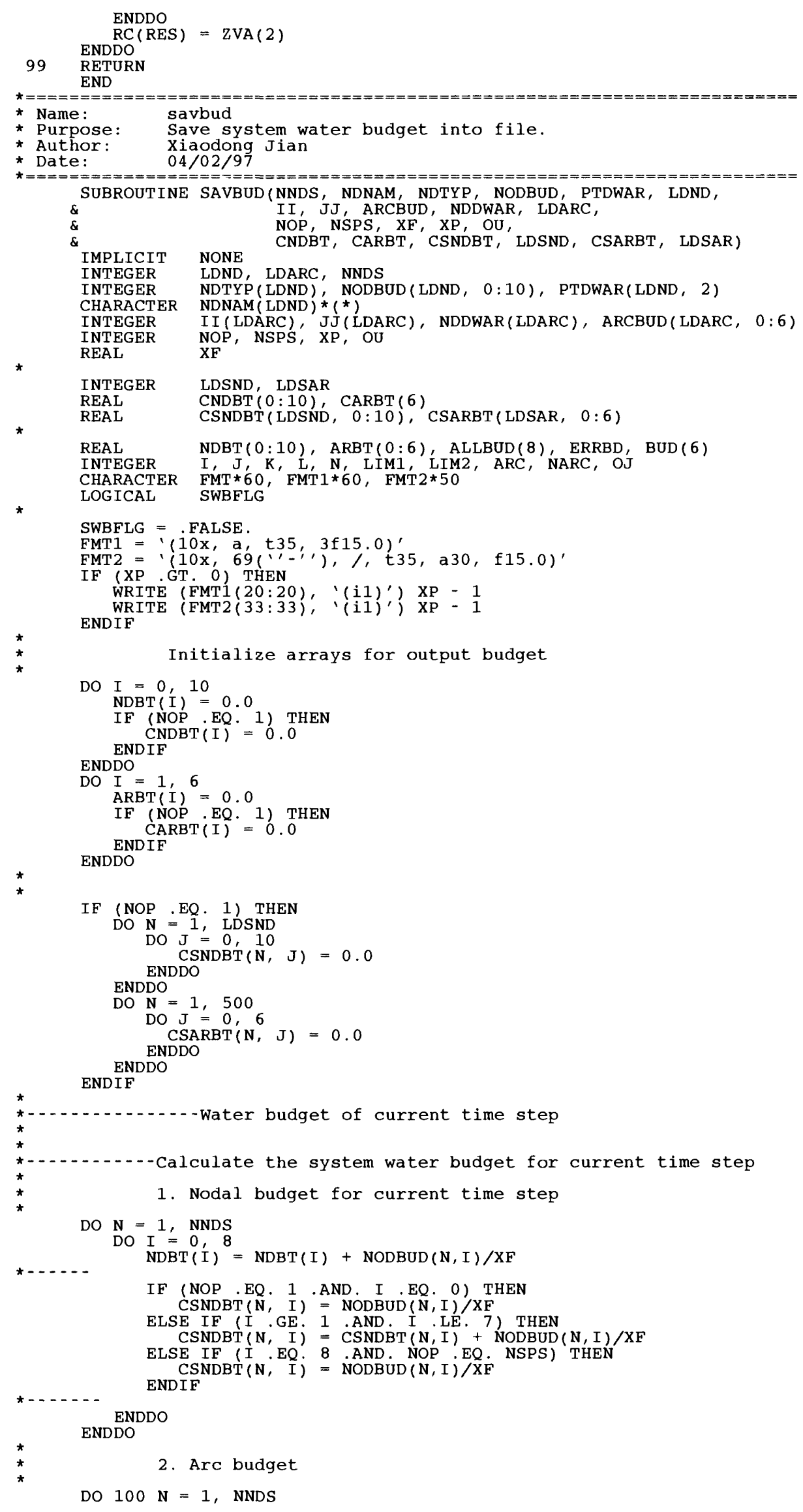




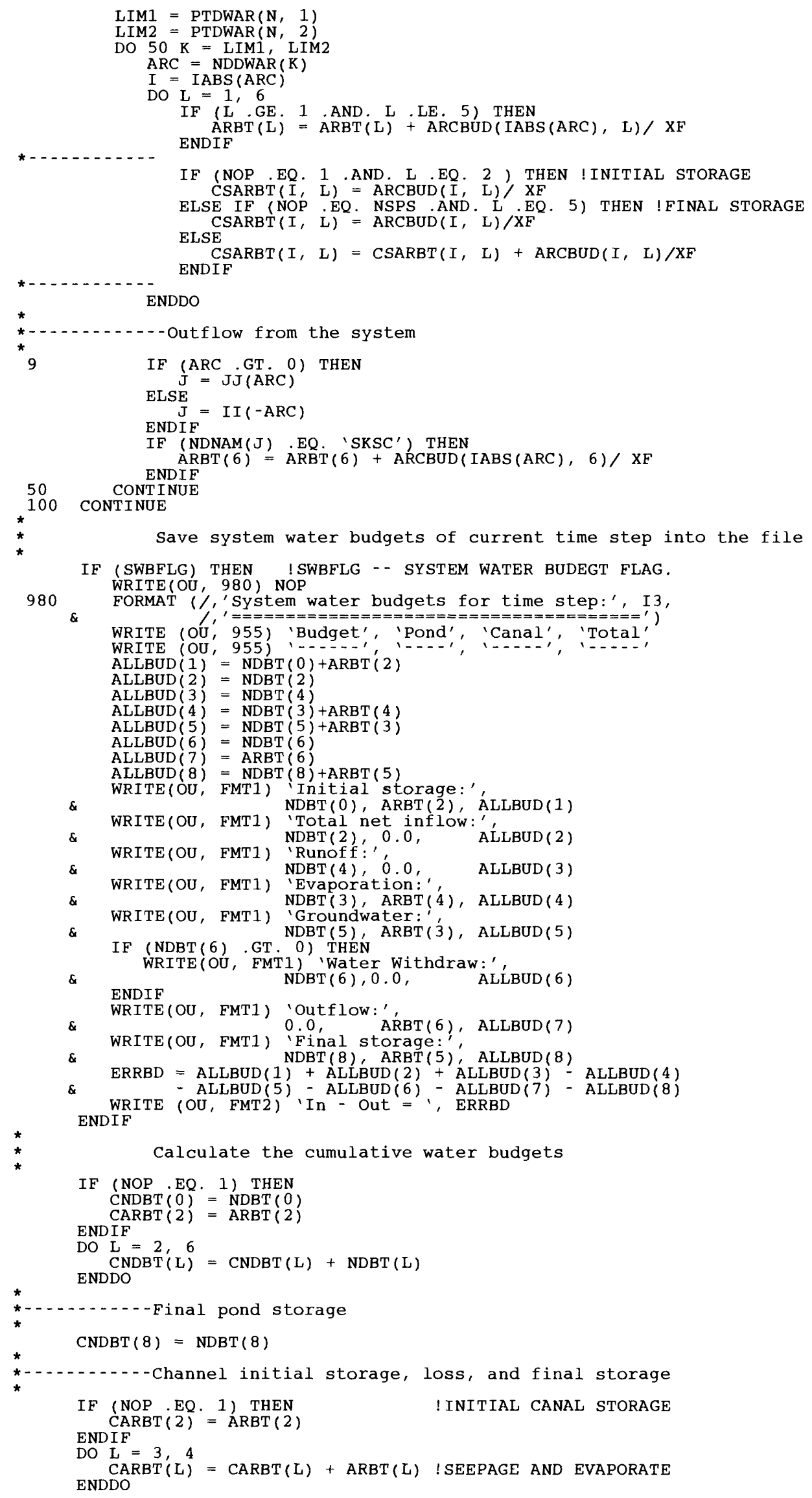




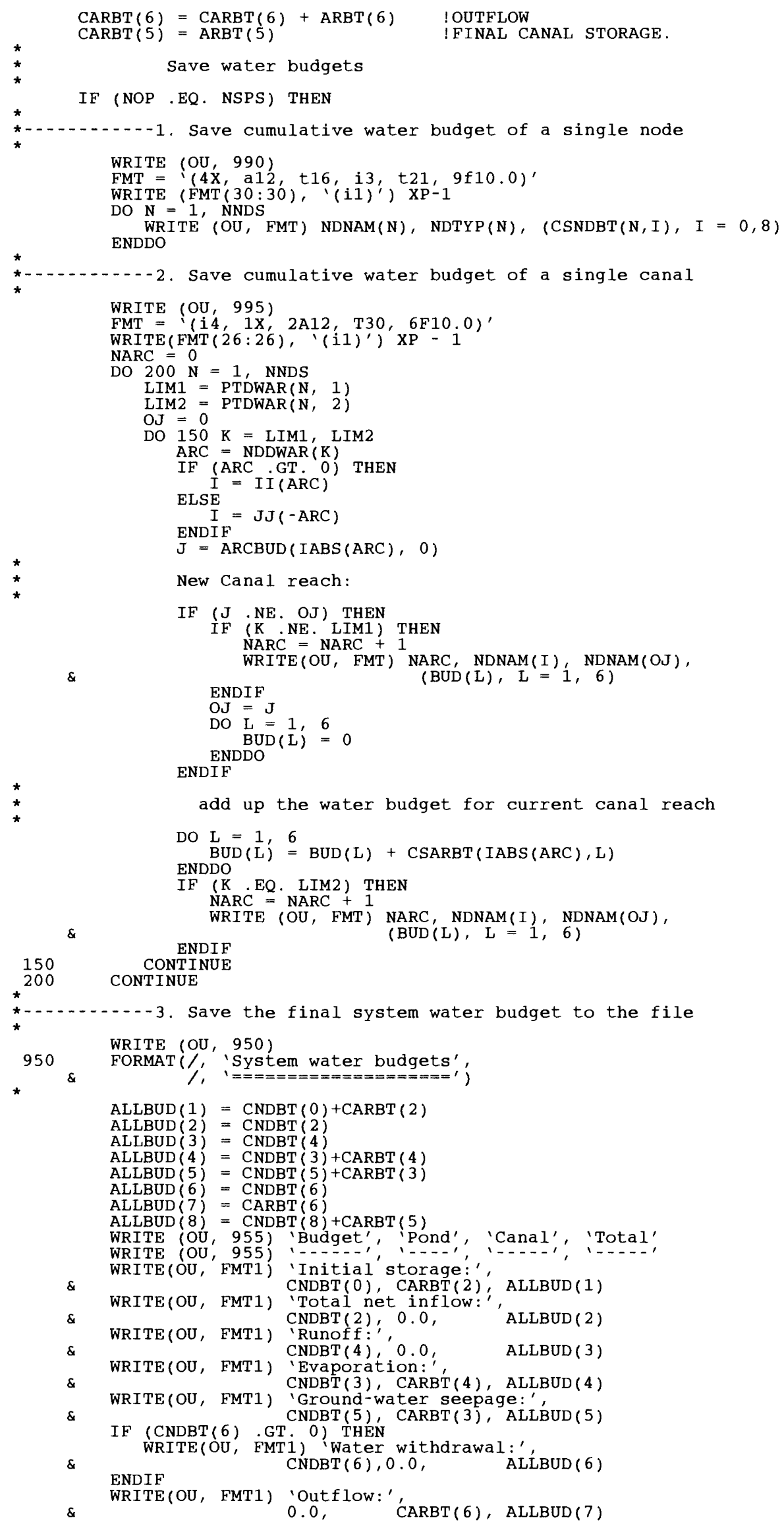


CNDBT(8), CARBT(5), ALLBUD(8)

ERRBD $=\operatorname{ALLBUD}(1)+\operatorname{ALLBUD}(2)+\operatorname{ALLBUDD}(3)-\operatorname{ALLBUD}(4)$

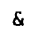

WRITE - ALLBUD ( 5) - ALLBUD (6) - ALLBUD (7) - ALLBUD (8)

ENDIF

RETURN

955 FORMAT (10X, A, T35, 3A15)

990 FORMAT(/,'Nodal water budgets for whole simulation',

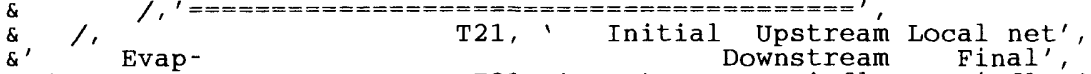

\&, Evap - T21, ' storage inflow Final' ${ }^{\prime}$, $\&^{\prime}$, ration Rainfall Seepage Withdrawal release storage', $\&, l^{\prime}$ Node', T16, 'Node', T21, ' (acre- (acre- (acre-',

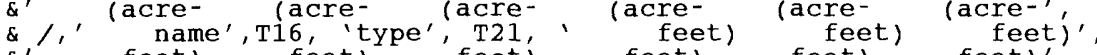
$\&^{\prime}$, feet) feet) feet) feet) feet) feet)',

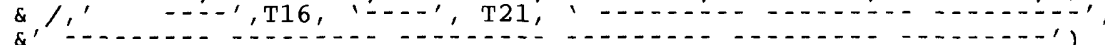

995 FORMAT(/,' Canal water budgets for whole simulation',
\& $1, \mathrm{~T} 30$,
Initial Canal
$\&$ I,T30,'

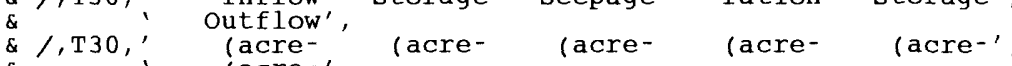
\& I, No; From' ('T18', 'To', fét) feet) feet) ',

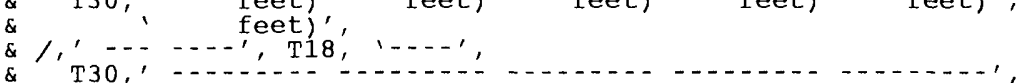
END

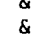

* Name:

* Purpose: Search the node number with the node name, or vice versa.

* Author: Xiaodong Jian

* Date: $\quad 9 / 13$

SUBROUTINE NAMNUM(NNOD, NDNAMS, NDNAM, NDNUM, IW, ERR)

IMPLICIT NONE

INTEGER NNOD, NDNUM, IW

$\begin{array}{ll}\text { CHARACTER } & \text { NDNAMS(NNOD)* }(*), \\ \text { LOGICAL } & \text { ERR, CN }\end{array}$

INTEGER I

$\mathrm{ERR}=. \mathrm{FALSE}$

IF (IW.EQ. O) THEN

DO $I \stackrel{0}{=}$, NNOD

IF (CN (NDNAMS (I), NDNAM, 1) ) THEN

NDNUM $=1$

ENDIF

ENDDO

ELSE

IF (NDNUM . LE. NNOD . AND. NDNUM . GE. 1) THEN NDNAM $=$ NDNAMS ( NDNUM)

ENDTF

ENDIF

ERR $=$. TRUE.

END 